\title{
WestVirginiaUniversity
}

THE RESEARCH REPOSITORY @ WVU

Graduate Theses, Dissertations, and Problem Reports

2016

\section{Ecological factors influencing incidence and severity of beech bark disease}

David P. McCann

Follow this and additional works at: https://researchrepository.wvu.edu/etd

\section{Recommended Citation}

McCann, David P., "Ecological factors influencing incidence and severity of beech bark disease" (2016). Graduate Theses, Dissertations, and Problem Reports. 6187.

https://researchrepository.wvu.edu/etd/6187

This Dissertation is protected by copyright and/or related rights. It has been brought to you by the The Research Repository @ WVU with permission from the rights-holder(s). You are free to use this Dissertation in any way that is permitted by the copyright and related rights legislation that applies to your use. For other uses you must obtain permission from the rights-holder(s) directly, unless additional rights are indicated by a Creative Commons license in the record and/ or on the work itself. This Dissertation has been accepted for inclusion in WVU Graduate Theses, Dissertations, and Problem Reports collection by an authorized administrator of The Research Repository @ WVU.

For more information, please contact researchrepository@mail.wvu.edu. 
Ecological Factors Influencing Incidence and Severity of Beech Bark Disease

David P. McCann

Dissertation submitted

to the Davis College of Agriculture, Natural Resources and Design

at West Virginia University

In partial fulfillment of the requirements for the degree of

Doctor of Philosophy in

Plant and Soil Sciences

\author{
William L. MacDonald, Ph.D., Chair \\ John R. Brooks, Ph.D. \\ Daniel G. Panaccione, Ph.D. \\ Yong-Lak Park, Ph.D. \\ Jennifer L. Koch, Ph.D. \\ Daniel B. Twardus, Ph.D.
}

Division of Plant and Soil Sciences

Morgantown, West Virginia

2016

Keywords: Beech bark disease, Cryptococcus fagisuga, Neonectria, ecological resistance, forest pest/disease management

Copyright 2016 David P. McCann 


\section{ABSTRACT \\ Ecological Factors Influencing Incidence and Severity of Beech Bark Disease}

David Page McCann

American beech have long been observed to escape both signs and symptoms of beech bark disease (BBD). Some may be resistant to Cryptococcus fagisuga (beech scale), a primary component of the BBD complex; research indicates about 1-2\% of American beech inherit resistance to beech scale. At the landscape level a variety of environmental factors may induce ecological resistance, a transient condition allowing potentially susceptible individuals to remain disease-free. This project investigated factors that may contribute to ecological resistance, focusing on biotic and abiotic stand characteristics and their relation to BBD incidence and severity. Plots were established at fifteen sites in the Appalachian region; overall, 3,142 beech were evaluated for disease incidence and severity on 102 plots. Over 100 parameters were generated from sampling and compared with Cryptococcus infestation or Neonectria infection. Correlation was used to characterize relationships between recorded parameters and scale infestation or Neonectria infection. Principal Component Analysis identified four important Principal Components (latent variables) composed of recorded parameters. Principal Component 1 (PC1) explained $9.39 \%$ of variation in the data; PC2 explained $6.40 \%$ of variation; PC3 explained $5.51 \%$ of variation; PC4 explained $4.58 \%$ of variation. Stepwise multiple regression analyses used Cryptococcus infestation, Neonectria infection, and Principal Components (latent variables) as predictors for the responses Cryptococcus infestation or Neonectria infection. Principal Component $1(\mathrm{p}=0.0014)$ and PC4 $(\mathrm{p}=0.0015)$ were significant for Cryptococcus infestation. The interactions of Cryptococcus infestation, PC1, and PC4 ( $\mathrm{p}=0.0147)$ and Cryptococcus infestation, PC1, PC3, and PC4 ( $\mathrm{p}=0.006)$ were significant for Neonectria infection. Spatial analyses indicate there is spatial dependence for infestation at Blackwater Falls, WV (variability explained $=79.2 \%$ ) and Great Smoky Mountains National Park, TN (variability explained $=52.9 \%$ ); and for infection at Allegheny National Forest, PA (variability explained $=$ $68.6 \%$ ) and Cranberry Wilderness, WV (variability explained $=60.9 \%$ ). This spatial dependence can partially be explained by inherited resistance and parameters composing significant latent variables. Finally, unusual blocky cankers regularly observed on beech but lacking viable Neonectria perithecia were sampled. Fusarium spp. were isolated from $85 \%$ of blocky cankers sampled; Fusarium colonies easily outcompeted and grew over Neonectria colonies when paired in culture and were statistically larger ( $\mathrm{p}$ < 0.005). Overall, this investigation supports observations that some beech trees remain disease-free by some mechanism other than inherited resistance, and numerous factors were identified that potentially influence dispersal and survival of BBD causal agents. 


\section{Acknowledgements}

This research was supported, in part, by U.S. Department of Agriculture Forest Service grant number 09-DG-11420004-171. I wish to give a special thanks to committee members John R. Brooks, Daniel G. Panaccione, and Yong-Lak Park, and especially advisor William L. MacDonald of the West Virginia University Davis College of Agriculture, Natural Resources and Design; and Jennifer L. Koch and Daniel B. Twardus of the U.S. Department of Agriculture Forest Service. I greatly appreciate Mark Double, Matthew Malone, Eric Goddard, Andrew Namick, James Savarino, and Matthew Berger of the West Virginia University Division of Plant and Soil Sciences, Alan Iskra, Danielle Martin, and Dan Snider of the U.S. Department of Agriculture Forest Service Northeastern State and Private Forestry, David Carey and Mary Mason of U.S. Department of Agriculture Forest Service Northern Research Station, Jill Rose of the West Virginia Department of Agriculture Division of Plant Industries, and Ariel Diliberto of Vassar College for their field and technical assistance. Thanks for their cooperation and assistance also are extended to Barbara Breshock of the Kumbrabow State Forest, Glenn Taylor of the Great Smoky Mountains National Park, and personnel with the following agencies: the Allegheny National Forest, Blackwater Falls State Park, Great Smoky Mountains National Park, Holden Arboretum, Kumbrabow State Forest, Monongahela National Forest, U.S. Department of Agriculture Forest Service-Northeastern State and Private Forestry, West Virginia Department of Agriculture, West Virginia University Extension Service, West Virginia University Division of Forestry and Natural Resources, and the West Virginia University Division of Plant and Soil Sciences. 


\section{Table of Contents}

Chapter 1: Literature Review

American Beech -- 1

The Beech Bark Disease Complex --- 2

Beech Bark Disease Causal Agents - 4

Beech Scale: Cryptococcus fagisuga -

Classification-- 4

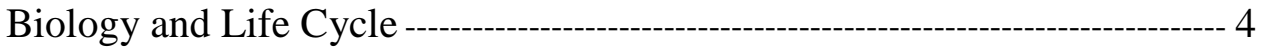

Population Dynamics --- 5

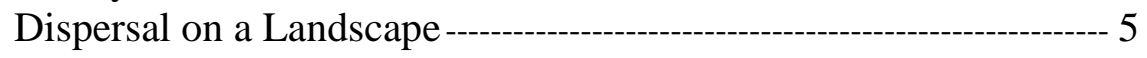

Dispersal in a Stand and Host Selection - 6

Environment----os 7

Natural Enemies and Allies --ב-_- 8

Neonectria Fungi -

Classification- 9

Anamorph Classification--- 9

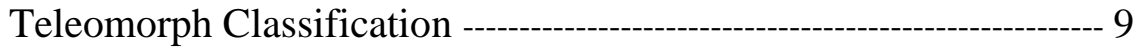

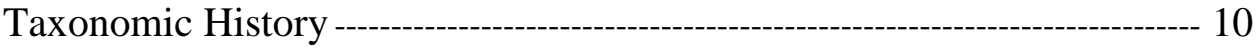

Biology and Life Cycle - 10

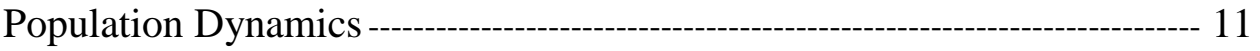

Disease Development -

Dispersal ---o- 12

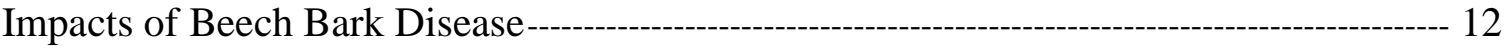

Management of Beech Bark Disease -- 13

Beech Resistance to Beech Bark Disease-1- 15

Inherited Resistance -

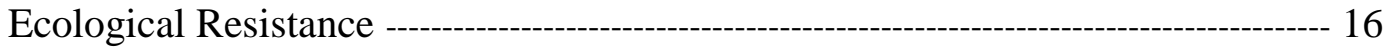

Factors Potentially Influencing Ecological Resistance---------------------------- 17

Chapter 2: Study of Ecological Factors- 18

Hypothesis and Objectives - --o 18

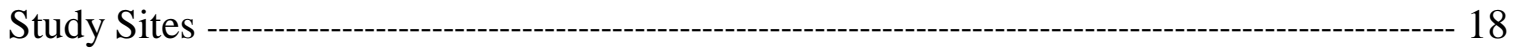

Methodology ---_- 19

Field - 19

Plot Establishment - 19

Stand Features --o 20

Cryptococcus Infestation and Neonectria Infection Ratings----_-_----- 20

Bark Organisms -----o- 21

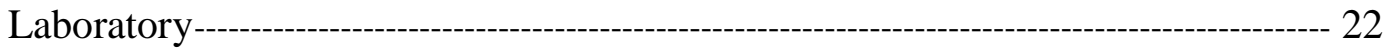

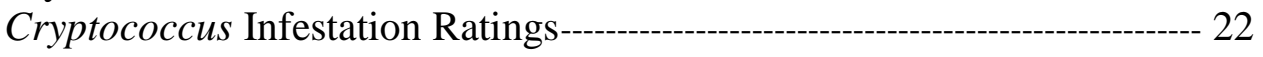

Neonectria Samples --- 22 


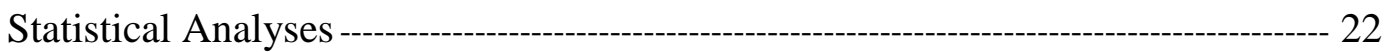

Cryptococcus Infestation and Neonectria Infection Ratings------------- 22

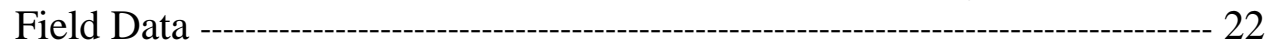

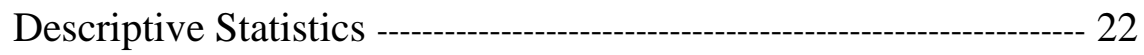

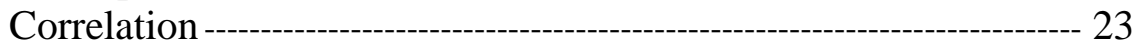

Principal Component Analysis and General Linearized Model --- 24

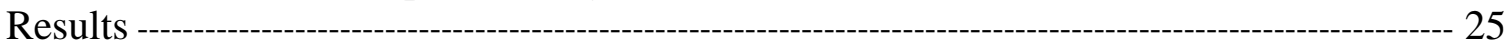

Spatial Analysis------------------- 24

Cryptococcus Infestation and Neonectria Infection Ratings------------------------- 25

Cryptococcus Infestation and Neonectria Infection --------------------------- 27

Species Composition with Cryptococcus Infestation or Neonectria Infection ---- 32

Cryptococcus Infestation-------------- 32

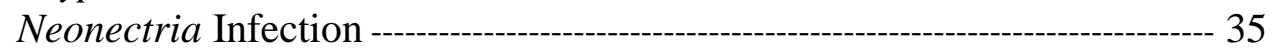

Analyses of Parameters Representing Ecological Factors --------------------------- 38

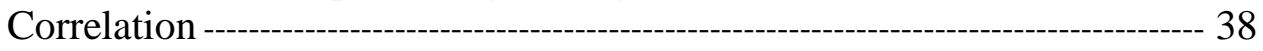

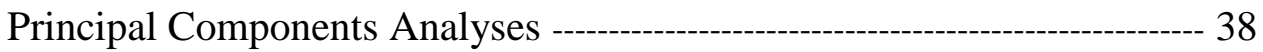

Stepwise Multiple Regression Analyses ---

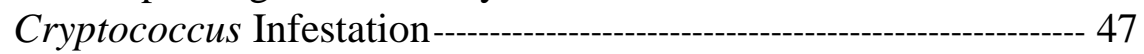

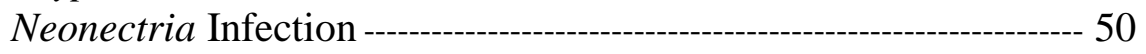

Spatial Analysis ------------------------------------------------------------------- 53

Cryptococcus Infestation-------------------------------- 53

Neonectria Infection ------ 54

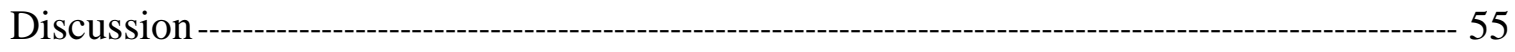

Cryptococcus Infestation and Neonectria Infection --------------------------------------- 55

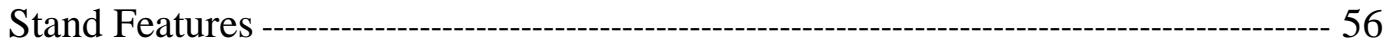

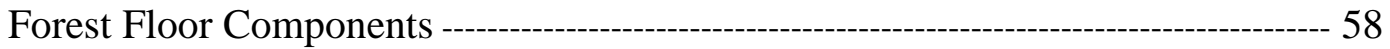

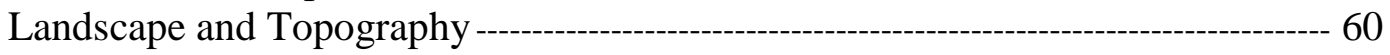

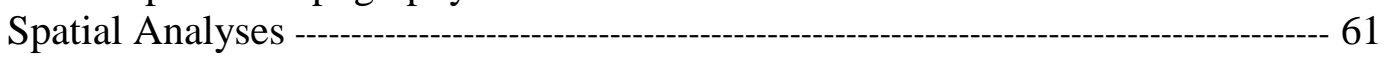

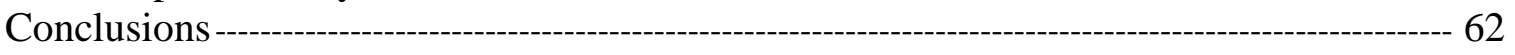

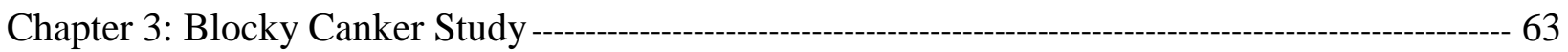

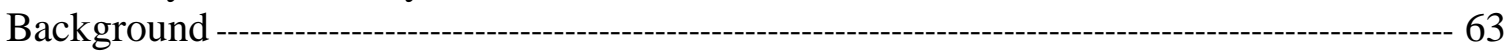

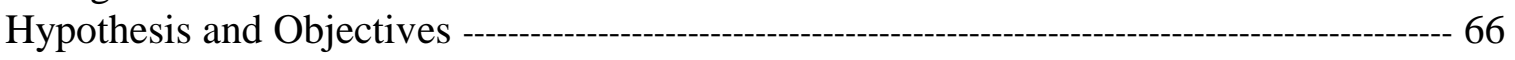

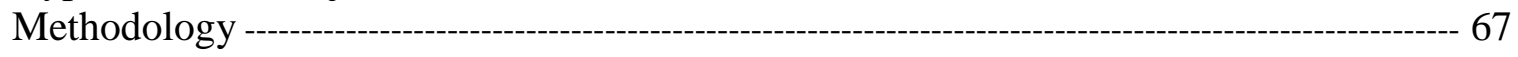

Fungal Identification --- 67

Fungal Growth and Competition -- 67

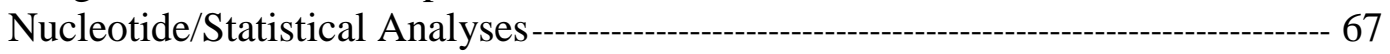

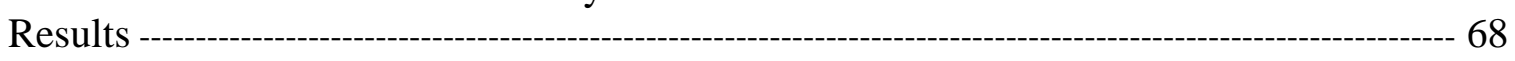

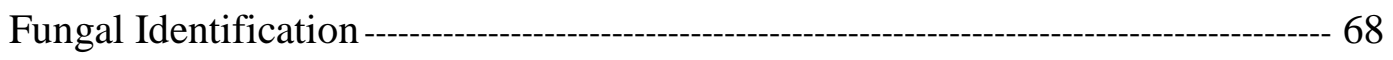

Fungal Growth and Competition -

Discussion --- 72

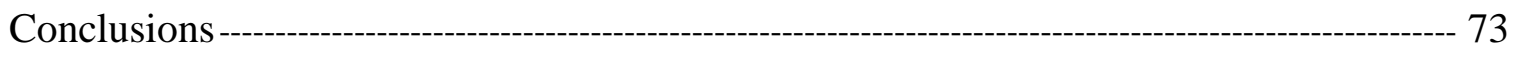

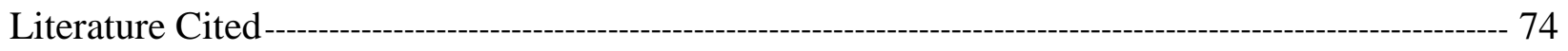

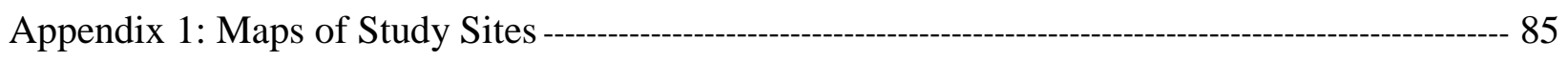




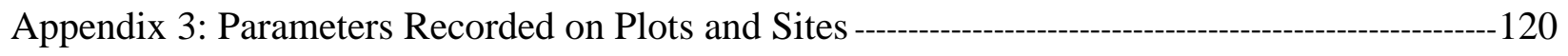

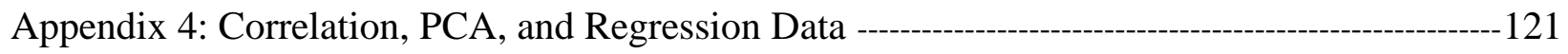

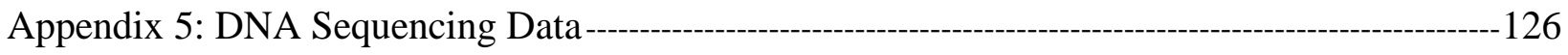

\section{List of Tables}

Table 1: Study sites in the Appalachian region

Table 2: Two-tailed F-test variance ratios $\left(\mathrm{F}=\sigma^{2}{ }_{1} / \sigma^{2}\right)$ and $\mathrm{p}$-values of five plots vs. ten plots for selected parameters measured at Shaver's Fork and Gaudineer sites-

Table 3: Descriptions of Cryptococcus infestation and Neonectria infection categories 21

Table 4: Mean Cryptococcus infestation Neonectria infection ratings at sites 28

Table 5: Mean Cryptococcus infestation of Fagus grandifolia by diameter class 30

Table 6: Mean Neonectria infection of Fagus grandifolia by diameter class30

Table 7: Loading values (absolute values) of parameters composing Principal Components (PC1PC4)/Latent Variables used as predictors for Cryptococcus infestation and Neonectria infection in stepwise multiple regressions. Absolute loading values indicate amount of variation in a parameter is explained by the Principal Component/Latent Variable; values $\geq 0.400$ (bold) are considered important (see Methodology section on Page 24 or JMP 12.0 instructions)----------- 46

Table 8: Estimates for latent variables used to predict Cryptococcus infestation in an initial stepwise multiple regression

Table 9: Estimates for latent variables used to predict Cryptococcus infestation in final stepwise

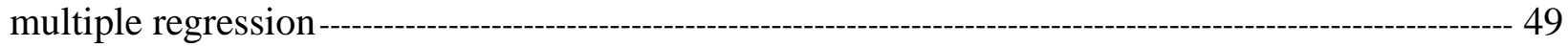

Table 10: Estimates for latent variables used to predict Neonectria infection in an initial stepwise

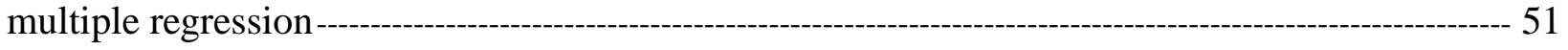

Table 11: Estimates for latent variables used to predict Neonectria infection in final stepwise

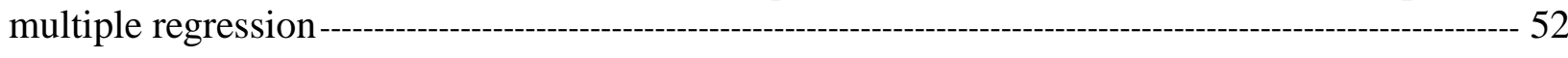

Table 12: Semivariogram parameters for Cryptococcus infestation at study sites in the Appalachian region

Table 13: Semivariogram parameters for Neonectria infection at study sites in the Appalachian region 
Table 14: Study sites in the Appalachian region where blocky cankers on Fagus grandifolia were sampled

\section{List of Figures}

Figure 1: Relationship between Cryptococcus infestation rating and mean number of Cryptococcus adults per $6.5 \mathrm{~cm}^{2}$ Fagus grandifolia bark

Figure 2: Relationship between Cryptococcus infestation rating and estimated Cryptococcus adult population per Fagus grandifolia calculated from estimated bark surface area ------------- 26

Figure 3: Relationship between Neonectria infection rating and mean number of cankers per $0.5 \mathrm{~m}^{2}$ Fagus grandifolia bark

Figure 4: Relationship between Neonectria infection rating and mean number of cankers per Fagus grandifolia calculated from estimated bark surface area

Figure 5: Percent Fagus grandifolia at study sites with Cryptococcus infestation ratings of None (0), Trace (1), Light (2), Moderate (3), and Heavy (4), $\mathrm{N}=3,142$ 28

Figure 6: Percent Fagus grandifolia at study sites with Neonectria infection ratings of None (0), Trace (1), Light (2), Moderate (3), and Heavy (4), $\mathrm{N}=3,142$

Figure 7: Percent Fagus grandifolia at study sites with concurrent Cryptococcus infestation and Neonectria infection ratings, $\mathrm{N}=3,142$

Figure 8: A: Woody debris, by species, at all 15 study sites. A: Coarse woody debris, percent of volume $\left(\mathrm{m}^{3}\right)$ B: Standing coarse woody debris, percent of volume $\left(\mathrm{m}^{3}\right)$ 31

Figure 9: Species compositions of plots $(\mathrm{N}=4,434)$ 32

Figure 10: Proportion of plots with trace (1), light (2), and moderate (3) Cryptococcus infestation ratings $(\mathrm{N}=102)$

Figure 11: Species compositions of plots with trace (1), $\mathrm{n}=72$; light (2), $\mathrm{n}=25$; and moderate (3), $\mathrm{n}=5$ Cryptococcus infestation ratings $(\mathrm{N}=102)$ -

Figure 12: Proportion of plots with none (0), trace (1), light (2), moderate (3), and heavy (4) Neonectria infection ratings $(\mathrm{N}=102)$

Figure 13: Species compositions of plots with none (0), $\mathrm{n}=9$; trace $(1), \mathrm{n}=30$; light $(2), \mathrm{n}=33$; and moderate (3), $\mathrm{n}=23$; and heavy (4), $\mathrm{n}=9$ Neonectria infection ratings $(\mathrm{N}=102)$ 38 
Figure 14: Scree plot of eigenvalues and Principal Components for Cryptococcus infestation data from plots ------- 39

Figure 15: Loading values plot of Principal Components 1 and 2-- 40

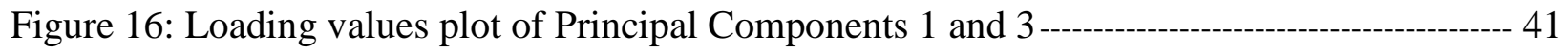

Figure 17: Loading values plot of Principal Components 1 and 4

Figure18: Loading values plot of Principal Components 2 and 3 33

Figure 19: Loading values plot of Principal Components 2 and 4

Figure 20: Loading values plot of Principal Components 3 and 4

Figure 21: Actual vs predicted Cryptococcus infestation (left) and residuals of predicted Cryptococcus infection values around the mean (right) for initial stepwise multiple regression. Dashed black lines are means; dashed red lines are the 95\% confidence interval; solid red line is a fitted line --- 48

Figure 22: Actual vs predicted Cryptococcus infestation (left) and residuals of predicted Cryptococcus infection values around the mean (right) for final stepwise multiple regression. Dashed black lines are means; dashed red lines are the 95\% confidence interval; solid red line is a fitted line

Figure 23: Contour plot and response surface for Cryptococcus infestation vs. climate, soils, stand structure and bark organisms, climate, forest floor-

Figure 24: Actual vs predicted Neonectria infection (left) and residuals of predicted Cryptococcus infection values around the mean (right) for initial stepwise multiple regression. Dashed black lines are means; dashed red lines are the 95\% confidence interval; solid red line is a fitted line

Figure 25: Actual vs predicted Neonectria infection (left) and residuals of predicted Cryptococcus infection values around the mean (right) for final stepwise multiple regression. Dashed black lines are means; dashed red lines are the 95\% confidence interval; solid red line is a fitted line

Figure 26: Contour plot and response surface for Neonectria infection vs. climate, soils, stand structure*bark organisms, climate, forest floor and climate, soils, stand structure*stand density and structure, wind patterns* bark organisms, climate, forest floor*Cryptococcus infestation--- 53

Figure 27: Spatial structures of Cryptococcus infestation at Blackwater Falls State Park II, WV (A) and Great Smoky Mountains National Park, TN (B) 
Figure 28: Spatial structures Neonectria infection at Allegheny National Forest, PA (A) and Cranberry Wilderness, WV (B) ----’- 55

Figure 29: Blocky cankers observed on Fagus grandifolia in Randolph County, WV ---------- 63

Figure 30: Fusarium canker on Acer sp. (Image from Sinclair and Lyon, 2005) and blocky canker on Fagus grandifolia in Randolph County, WV ------------------о------о------ 64

Figure 31: Discolored tissues under blocky cankers on Fagus grandifolia in Randolph County, WV

Figure 32: Epicormic sprouts growing from blocky cankers on Fagus grandifolia in Tucker County, WV

Figure 33: Blocky canker on Fagus grandifolia in Tucker County, WV. Neonectria fruiting is not evident in the encircled blocky area 65

Figure 34: Blocky canker on Fagus grandifolia with dead Neonectria perithecia (A) and Neonectria cankers with viable perithecia (B) in Randolph County, WV

Figure 35: Blocky canker with Cryptococcus on Fagus grandifolia in Randolph County, WV - 66

Figure 36: Total number of blocky beech cankers sampled at seven sites in the Appalachian region from which Fusarium, Phomopsis, or Neonectria spp. were isolated; total cankers sampled $=403$. Statistically more cankers had Fusarium than Phomopsis or Neonectria $(\mathrm{p}<$ $0.005)$

Figure 37: Total number of Fagus grandifolia stems sampled at seven sites in the Appalachian region from which Fusarium, Phomopsis, or Neonectria spp. were isolated; total beech sampled = 140; Statistically more Fagus grandifolia stems had Fusarium than Phomopsis or Neonectria $(\mathrm{p}<0.005)$

Figure 38: Fusarium species in the Fusarium tricinctum complex (Images from Nelson et al., 1983)

Figure 39: Fusarium species isolated from blocky cankers on Fagus grandifolia in the Appalachian region

Figure 40: Mean diameter (mm) of Fusarium and Neonectria colonies after 7 and 14 days on PDA $(n=10)$. Means were calculated from measurements of two perpendicular axes on each of ten colonies. Fusarium colonies were statistically larger than Neonectria colonies after 7 and 14 days $(\mathrm{p}<0.005)$---о- 70

Figure 41: Individual Fusarium colony (left) and Neonectria colony (right) after 14 days ------- 70 
Figure 42: Mean diameter (mm) of paired Fusarium and Neonectria colonies after 7 and 14 days on PDA $(n=10)$. Means were calculated from measurements of two perpendicular axes on each of ten colonies. Fusarium colonies were statistically larger than Neonectria colonies after 7 and 14 days $(p<0.005)$

Figure 43: Paired Fusarium (left side of plate) and Neonectria (right side of plate) isolates after 14 days. The Neonectria colony is overgrown by the Fusarium colony and statistically smaller than Neonectria colonies grown without Fusarium ( $<<0.001)$

Figure 44: Light microscope image of Fusarium fungus and Neonectria faginata growing together in the same medium. There are no connections between the adjacent hyphae of each fungus that would indicate physical interaction 


\section{Chapter 1: Literature Review}

\section{Fagus grandifolia}

American beech (Fagus grandifolia Ehrh.) is the only accepted native species of the genus Fagus in the United States, although local races and one variety may be recognized. Camp (1950) distinguished three races. Gray beech is found at high elevations from North Carolina northward and low elevations in Nova-Scotia; red beech occurs at mid-elevations in the southern Appalachians; and white beech occupies foothills and lowlands in the south and along the east coast. The one accepted variety is Carolina beech, $F$. grandifolia var. caroliniana (Little, 1953), which ranges from swamp-lands to high elevations throughout the south and north to New Jersey and Ohio (Rushmore, 1961). Another North American variety growing in northeastern Mexico, $F$. grandifolia var. mexicana (Little, 1965), was formerly given species status as $F$. mexicana (USDAFS, 1965).

The overall range of American beech extends from the southern regions of Canada's eastern provinces south to northern Florida and from the Atlantic Coast west to Wisconsin and eastern Texas (Rushmore, 1961; Little, 1979). Prior to glacial activity in North America (NA) beech ranged as far west as California and likely inhabited most of the continent (Berry, 1916; USDAFS, 1965). Outside North America Fagus spp. are broadly distributed in Europe, West Asia, and East Asia (Fang and Lechowicz, 2006). Europe and West Asia each have one species, $F$. sylvatica L. and F. orientalis Lipsky, respectively (Jalas and Suominen, 1991). East Asia has four Chinese species (F. engleriana Seem., F. longipetioliata Seem., F. lucida Rehder and Wilson, and $F$. hayatae Palib.), two Japanese species ( $F$. crenata Blume and $F$. japonica Maxim.) (Horikawa, 1972), and one Korean species (F. multinervis Nakai) (Kim, 1988).

American beech is a slow growing, long-lived, highly shade tolerant hardwood species, potentially living 350-400 years (Carpenter, 1974). It normally grows up to 80 feet tall, but ideal sites and conditions can produce individuals up to 120 feet tall (Brown, 1922). Diameters at breast height (DBH) average from 18-50 inches (Carpenter, 1974), and crown spreads can reach 80 feet or more (American Forestry Association, 1951). The roots of beech form a spreading, shallow heart root system (Rust and Savill, 2000) and root and stump sprouting are common. Growth is best in moist, well-drained soils of loamy texture and high humus content (Westveld, 1933) and the largest specimens are found in bottomlands of the Ohio and Missouri Rivers and western slopes of southern Appalachia (Carpenter, 1974).

Beech can grow in pure stands but is most often an associate in a mixture of species (Carpenter, 1974). American beech is an important component of four cover types: northern hardwood, Allegheny hardwood, Appalachian mixed hardwood, and bottomland mixed hardwood (Harlow et al., 1979; Burns 1983). Common associates include sugar maple (Acer saccharum Marsh.), black cherry (Prunus serotina Ehrh.), eastern white pine (Pinus strobus L.), red spruce (Picea rubens Sarg.), hemlock (Tsuga canadensis (L.) Carr.), hickories (Carya spp. Nuttall), oaks (Quercus spp. L.), and yellow birch (Betula alleghaniensis Britt.) (Rushmore, 1961).

Considering its low commercial value relative to common associates and high susceptibility to decay, American beech is often considered a nuisance species in forest management. Particularly 
in stands affected by beech bark disease where thickets of beech develop from root and stump sprouts. However, it is hard, strong and useful for veneer, pulping, railroad ties, flooring, furniture, and pallets for food storage (Carpenter, 1974). Its value as a fuel-wood is nearly equal to white oak (Mielke et al., 1986). Beech is important ecologically as a climax species (Halls, 1977) and resource for wildlife (Jakubas et al., 2005; Storer et al., 2005). Co-dominant beech help maintain microenvironments important to native organisms in hardwood forests (Storer et al., 2005), and rapid decay creates cavity and open nest sites for wildlife (Robb and Bookhout, 1995).

American beech also is a source of food for wildlife. The foliage and bark of beech offers foraging opportunities for insects, birds and mammals (Holmes and Schultz, 1988). Beechnuts are consumed by many birds, including blue jays, and numerous mammals (Perrins, 1966; Halls, 1977; Brown and Will, 1979; McLaughlin et al., 1994; Wolff, 1996; Heyd, 2005; Storer, et al., 2005). Squirrels (Sciurus spp. L.) eat catkins (Halls, 1977), and numerous animals eat the bark, including mice (Peromyscus spp. Gloger), a beaver (Castor canadensis Frazier) (Rushmore, 1961), and rabbits (Sylvilagus spp. Gray) (Hamilton, 1955). Furthermore, black bear (Ursus americanus Pallas) and marten (Martes americana Turton) populations are adversely affected by reductions in beech mast (Jakubas et al., 2005). Beech bark disease has not removed beech from the landscape in North America and a full understanding of the disease complex could help improve management of the disease and avoid the loss of this important ecosystem component.

\section{The Beech Bark Disease Complex}

Beech bark disease (BBD) is a complex of interacting causal agents, primarily the beech scale, Cryptococcus fagisuga Lindnger (Hemiptera: Eriococcidae) and several species of Ascomycetous fungi now classified in the genus Neonectria Wollenw. (Hypocreales:

Nectriaceae). The two components injure beech individually, but serious damage does not occur without their combination (Shigo, 1964). Beech scale infestation is indicated by wool-like wax secretions of nymphs and adults that appear as white flecks on boles in low-density infestations or give trees a whitewashed appearance at high densities. Mechanical injury from sapfeeding by beech scales facilitates fungal inoculation (Felt, 1933; Ehrlich, 1934; Lonsdale, 1979). As the beech scale feeds pectinases in its saliva precondition bark tissues for severe fungal invasion (Perrin, 1983). Conversely, bark tissues infected with Neonectria fungi are unfavorable scale habitat (Houston and O'Brien, 1983). The initial symptom of Neonectria infection is a slime flux or oozing sap produced by the fermentation of necrotic tissues by secondary saprophytic fungi (Ehrlich, 1934). Fungal infection affects the vascular system as perennial cankers kill bark tissue, yellow crowns, reduce leaf area, and possibly kill trees when stems are girdled (Ehrlich, 1934; Gate, 1988). Although evidence to date indicates Neonectria infection of beech is a function of beech scale infestation, severe infections do occur under low level infestation and Neonectria fungi can cause cankers on various tree species in the absence of scale attack (Houston, 1994a).

Numerous interacting factors predispose an individual tree to invasion by causal agents, incite further decline, and contribute to tree death (Manion, 1991). Individuals weakened by BBD may accordingly become predisposed to further decline through the activities of organisms inciting continued stress and then perhaps contributing to eventual death. Scolytid beetles often infest diseased beech and their galleries may then serve as infection courts for decay fungi, particularly 
the white rot Fomes fomentarius (L.) J.J. Kickx (Brower, 1949). Fomes infection leads to "beech snap" when boles break 3-5 m feet high, often due to wind (Gate, 1988).

Beech bark disease has been known in Europe for over 150 years (Ehrlich, 1934). There it is of concern because of its affects on beech plantations. In forest stands it often is a novelty, with disease pockets developing around a single infected tree that presumably serves as an inoculum source. The coevolution of the causal agents and host has resulted in significant resistance and a discontinuous distribution of infested trees in European forests (Wainhouse and Howell, 1983). Generally only single or small groups of trees die as the disease develops there whereas in North America the exotic nature of the beech scale-American beech relationship results in a different pattern of infestation and can lead to death of whole stands.

Near the end of the $19^{\text {th }}$ century European beech $(F$. sylvatica) saplings were shipped into Halifax, Nova Scotia in Canada (Ehrlich, 1934). These saplings were part of the city's public gardens when an infestation of beech scale was noticed around 1890. In the 1920's heavy American beech mortality occurred in the vicinity of Halifax at which time John Ehrlich of Harvard University began investigating the causal complex (Houston, 2005). Beech bark disease has moved south and west since its introduction into Nova Scotia. However, it has yet to spread through the entire range of American beech. Currently the disease is spreading through West Virginia, Ohio, and Virginia. Outlying infections in Tennessee, North Carolina, and Michigan also are known (Morin et al., 2005). Beech bark disease has reached less than $30 \%$ of the range of beech while spreading an estimated $14.9+/-0.9 \mathrm{~km} /$ year (Morin et al., 2007). Movement of the disease in North America has been characterized as frontal in nature. Shigo (1964) first described two phases of disease in North America. In this early characterization there was an initial Cryptococcus phase of epidemic BBD causal agents and heavy infection of larger trees as the disease advanced. A Xylococculus phase followed when the disease was well established in low level infections on smaller stems and native organisms were more influential. Shigo (1972) later described the spatial and temporal distribution of BBD in North America with three phases of disease progression:

- The advancing front: characterized by the introduction of beech scale followed by development of small but accumulating scale populations hosted by large mature trees with little Neonectria infection.

- The killing front: characterized by large, epidemic beech scale populations and copious Neonectria infections. Heavy and widespread mortality with quickly dying trees over large areas is prevalent.

- The aftermath zone: an area of established and endemic beech scale and Neonectria populations; widespread mortality with some large surviving beech that may be disease free or exhibit varying degrees of cankering. Thickets of small root sprouting beech arise from dead, susceptible individuals and often are highly susceptible to BBD, resulting in many defective small stems from the attack of established causal agents. Bark beetles and decay fungi attack dead and weakened individuals, encouraging beech snap.

However, BBD does not operate strictly on a frontline. Outlying pockets of disease ahead of or in an advancing front expand and coalesce into a killing front, which may have pockets of an advancing front within it. Likewise, aftermath zones may have pockets of advancing or killing 
fronts within them. In the last 20 years 10 cases of isolated pockets of scale infestation ahead of an advancing front have been documented (Morin et al., 2007). The lines between Shigo's phases are blurred and BBD often progresses as a conglomeration of eruptive centers of disease emanating from randomly distributed inoculation sources. Human activities likely exacerbate this distribution as evidenced by outlying disease centers in natural areas with high visitation. Whatever the case, the establishment of BBD in a stand is dependent on beech scale infestation. The Neonectria fungal component of the BBD complex is an opportunistic weak pathogen capitalizing on wound sites created by beech scales. Infections can normally be contained by defenses of healthy hosts but when scale infestation is intense enough to present Neonectria fungi the opportunity to overwhelm hosts infection is severe and BBD may be a serious threat to a stand. Given the dynamic nature of BBD, stand characteristics affecting beech scale infestation and Neonectria infection interact in a complex way, influencing each other as well as the beech scale and BBD.

\section{Beech Bark Disease Causal Agents}

\section{Beech Scale: Cryptococcus fagisuga}

\section{Classification}

Cryptococcus fagisuga is native to Europe and in super-family Coccoidea, family Eriococcidae. Common names included various combinations of the terms felt scale, beech coccus, and felted scale before the common name beech scale was widely accepted (Gate, 1988). In the early 1800's the beech scale was originally misconstrued to be a fungus and named Psilonia nivea until Baerensprung identified it as an insect in 1849 and called it Coccus fagi (Ehrlich, 1934). Others then classified it in the Adelges, Psylia, and Chermes genera and the genus Pseudococcus was widely used until 1890 when the organism was given the name Cryptococcus fagi Baerensprung by Douglas. The current designation of Cryptococcus fagisuga Lindinger was applied in the early 1900's (Gate, 1988).

\section{Biology and Life Cycle}

Gate (1988) developed a good description of the beech scale in Europe but the overwintering stage seems to differ in North America. Cryptococcus fagisuga is univoltine. Eggs are laid in summer and the first instar crawlers are dorsoventrally flattened with well-developed legs and antennae. Crawlers (nymphs) are about $0.3 \mathrm{~mm}$ long and active from mid-summer to late fall while searching for a site to feed and settle. After settling they lose their legs, cover themselves in a protective woolly wax and overwinter as first instars. Molting occurs and second instars appear from April through June, they remain legless and immobile before molting into adults from May to September. Parthenogenic regeneration excludes males. Adults are entirely female, ovoid, wingless, and have one pair of rudimentary legs and reduced antennae. They are about $1 \mathrm{~mm}$ long and remain affixed to their feeding site where they retain their filamentous wax under which they will lay about fifty eggs, each about $0.3 \mathrm{~mm}$ in length and hatching in approximately 25 days. Houston and O'Brien (1983) describe a similar beech scale life cycle in North America but the second instar is the overwintering stage. 
The beech scale has piercing/sucking mouthparts twice the length of its body. It feeds primarily intracellulalry in bark parenchyma but in the least developed bark access to the outer phloem tissue may be possible. Feeding occurs parallel and perpendicular to the bark surface through repeated probing from a single insertion point (Gate, 1988). Since a lack of mobility likely limits long range attraction through pheromones that occurs with some insects, the probing action of the stylet indicates taste is more important than attraction in finding a suitable host site (Gate, 1988). Galls of bark tissue sometimes form at insertion points (Lonsdale, 1983a). These galls may be a host reaction to compound injected in scale saliva. Scale attack itself is rarely lethal or even significant without the interaction of Neonectria fungi (Brower, 1949). However, large colonies can create necrotic tissues in cortex regions and impair cambial tissues (Lonsdale 1983a) and cortical necrosis generates bark abnormalities or stem disfigurement in highly susceptible individuals (Wainhouse and Gate, 1988).

\section{Population Dynamics}

\section{$\underline{\text { Dispersal on a Landscape }}$}

Long distance beech scale dispersion is predominantly wind driven in North America but humans move scales in beech material and phorecy with birds and other organisms disperses scales (Felt, 1933; Ehrlich, 1934). Wind dispersal is related to the size and shape of an object (Raynor et al., 1974). The dorsoventrally flattened shape and setae of crawlers increase their surface area and decrease their terminal velocity relative to eggs allowing them to travel higher and further, making them the main dispersal stage (Ehrlich, 1934; Brower, 1949; Wainhouse, 1980; Gate, 1988). Mobile crawlers that appear from June to November are the only stage in the beech scale life cycle available for wind dispersal (Wainhouse, 1980; Gate, 1988).

The microscopic size of beech scales allows contemplation of their dispersal based on a model for particulate matter described by Raynor et al. (1974). Wind dispersal is related to the morphology of an object, the prevailing wind, topography, and ground cover. As particulate matter enters a forest from an open field lateral spread is enhanced as wind speeds decrease, but this effect decreases rapidly with distance into the forest. The density of a stand affects the amount of convection that occurs, with denser stands creating more upward and less horizontal drafts. Vertical spread increases the potential for long-range dispersal.

Turbulence below a canopy is reduced relative to within or above the canopy (Raynor at al., 1974). The majority of beech scales are transported a short distance horizontally from a host by low level drafts within stands, but some carried above the canopy by convection and upper level drafts are shuttled long distances. Trapping studies suggest the proportion of beech scales actually traveling long distances is relatively low (Wainhouse, 1980). Wind speed during scale dispersal affects travel distance. Rapid winds above the canopy carry scales across a landscape nearly $15 \mathrm{~km} / \mathrm{yr}$ (Morin et al., 2007). This long range dispersal could explain outlying beech scale populations found on islands off the Maine coast (Brower, 1949) and North Carolina, Tennessee, and Michigan (Houston, 1994a). Crawlers move on hosts in search of suitable feeding sites and in response to positive phototaxy, aggregating into columns (Houston et al., 1979a; Gate, 1988). Some scale insects actively launch themselves into wind currents to be dispersed (Willard, 1979). There is evidence of launching behavior by crawlers, and when 
migrating high up a tree by they may encounter upward currents to be dispersed long distances (Gate, 1988).

Wind dispersal and positive phototaxic beech scale behavior (Gate, 1988) indicate canopy features may affect scale distribution. In a study of canopy classes Gove and Houston (1996) found co-dominant trees began to decline decades before intermediate trees. Dominant and codominant beech crowns may intercept dispersing beech scales, whereas non-beech dominants and co-dominants may filter dispersion and prevent contact with a host, the efficacy of which may vary with species. Thinned stands in Europe and North America experienced temporary reductions in scale populations (Parker, 1980 and1983; Crosby and Bjorkbom, 1958). Thinner canopies let in more light, luring scales higher in the tree where they can disperse greater distances, and let more particulates, including dispersing scales, into or out of a stand in air currents. Temporary reductions in scale populations from thinning could be offset by the entry of dispersing scales through thin canopies. Less dense canopies also let out moisture leading to drier, more exposed trunks which may deter scale, but they also let in more precipitation. Although beech scales may move in stemflow and ground water or be splashed from host-to-host precipitation negatively influences scale establishment by washing them from hosts (Kasson and Livingston, 2012) more than it facilitates dispersal within or out of a stand.

\section{$\underline{\text { Dispersal in a Stand and Host Selection }}$}

Beech scale has long been considered a European native, but there is evidence emerging that indicates it is native to Asia (Gwiazdowski et al., 2006). Stand distributions of native (presumably) and exotic beech scale populations differ. The more or less random, heavy infestation of trees is indicative of native populations found in Europe (Wainhouse and Gate, 1988), whereas the somewhat frontal nature of scale spread described above occurs with exotic populations in North America (Houston et al., 1979b). Beech density, distribution, and size influence scale distribution and infestation in stands. Houston et al. (1979a) found prevailing wind direction and distance from an inoculum source significantly affect scale infestation. Rates of beech scale spread within in a stand averaged $10.2 \mathrm{~m}$ horizontally and $15.1 \mathrm{~m}$ vertically at winds of $0.75 \mathrm{~m} / \mathrm{s}$ in a study by Wainhouse (1980).

Susceptible beech must be in proximity to an inoculum source for beech scales to generate new pockets of infestation. In England, European beech older than 15 years commonly host small beech scale populations while 20-40 year old individuals experience stronger attacks (Wainhouse and Gate, 1988). Indeed, larger, older, trees are considered more susceptible to heavy scale infestation in Europe and North America; stands with larger diameter and older beech may be more likely to develop severe infestations (Ehrlich, 1934; Mize and Lea, 1979; Houston, 1994a; Latty et al., 2003).

The established scales and fulfillment of their entire reproductive potential are key factors in population growth and directly related to host quality (Gate, 1988). Varying levels of key nutrients may benefit scale development or tree survival. Some researchers indicate beech scale favors more vigorous hosts (Gate, 1988), while others maintain vigor can help beech limit infestation and improve chances of survival (Burns and Houston, 1987). Although the relationship between vigor and scale infestation seems unclear, elevated bark nitrogen may facilitate heavy scale infestation while lower nitrogen $(\mathrm{N})$ may confer resistance (Wargo, 1988). 
Nitrogen is an essential nutrient required for beech scale growth and reproduction. Latty et al. (2003) and Latty (2005) detailed relationships between beech size, age, site quality, beech scale infestation and $\mathrm{N}$ storage and cycling. Nitrogen is the key limiting factor for scale infestation until a stand reaches $\mathrm{N}$ saturation, then available feeding space becomes limiting. Large, old beech trees on quality sites have higher bark nitrogen contents and stands with relatively little to no history of disturbance develop larger $\mathrm{N}$ pools.

When experimenting with forest trees and endemic scale populations in England, Wainhouse and Howell (1983) found evidence of preferentially colonized trees. This potential intraspecific variation in scale populations and implied variation in host defenses has been described as hosttracking and could lead to the development of a population increasingly preferring a specific host tree (Edmunds and Alstad, 1978). A resulting pre-adaptation for a selected set of tree defenses may develop in a population of scales, leading to the rapid growth of a large population on single trees (Lonsdale, 1980). Parthenogenic reproduction by the scale would further facilitate such development. Wainhouse and Gate (1988) determined the host-scale interaction to be most important to density on a given individual, specifically, genetics of both the host and scale have led to adapted scale populations (Houston et al., 1979a; Wainhouse and Howell, 1983).

The only discernable density dependent regulation of beech scale occurs at the crawler stage and is related to settling site availability (Wainhouse and Gate, 1988). Crawler mortality on individual hosts is as high as $86 \%$, with $10-20 \%$ of scales dispersing; the high mortality of crawlers on trees is related to the failure to become established (Gate, 1988). Although European beech has a certain level of resistance to beech scale that developed from their coevolution, the monoculture of beech in Europe renders some landscapes susceptible to heavy infestation (Wainhouse and Howell, 1983). In North America, the sprouting nature of beech and lack of beech harvesting provide an exotic, highly susceptible population (Houston, 1975).

\section{$\underline{\text { Environment }}$}

Numerous abiotic and biotic factors can influence beech scale populations. The beech scale is well known as a pest enjoying cooler temperatures in temperate climates that help define its range. In a study of canopy classes and decline due to disease, stands in central Maine had a more rapid progression of decline to lower canopy classes than stands closer to the southern coast of Maine (Gove and Houston, 1996). Differences were partly attributed to climate and stand dynamics, with the coastal stands having less harsh winter conditions. Local climatic and topographic features affecting dispersal may combine to create microclimates. Extreme winter temperatures (lethal $<-34^{\circ} \mathrm{C}$ ) and heavy rainfall negatively affect scale populations (Houston and Valentine, 1988; Kasson and Livingston, 2012). Canopy density affects microclimates within a stand by letting in more or less sunlight and influencing wind currents. Areas where cold air settles like valleys may resist scale infestation.

Topography creates microclimates with very cold or wet conditions affecting scale survival and may influence the settling of wind dispersed scales. Research by Houston et al. (1979a) suggests mid-slopes have greater scale infestations than upper or lower slopes, and Ehrlich (1934) reports beech should be favored on high broad ridges and selected against on steep slopes. Brower (1949) found beech became more heavily infested on north facing bole sections, and beech scales may prefer tree aspects based on exposure to wind, sun, and rain or the presence of bark 
organisms (Ehrlich, 1934; Houston et al., 1979a; Houston, 1983) . Relationships between stem surface aspect and scale infestation could project to the stand level.

The effects of BBD and selection of non-beech during harvest have led to highly susceptible stands ideal for new outbreaks in areas long affected by BBD (Houston, 1975). The removal of trees in managed stands may reduce nutrient pools relative to unmanaged stands (Latty et al., 2003). Disturbances, natural or human induced, alter succession, the allocation of nutrients, and growing space within a stand and associated changes in microclimates can influence scale distribution.

\section{$\underline{\text { Natural Enemies and Allies }}$}

As a bark feeder the beech scale is affected by other bark organisms that may assist or inhibit its ability to settle on a feeding site. Lichens vary in their affect on beech scales, some benefit scale with protection while others inhibit their establishment. Various lichen species in Canada seem to assist or prevent settling of scale insects and crustose lichens generally inhibit scale infestation (Houston, 1983). However, a crustose lichen in Europe, Lecanora conizaeoides Nye ex Cromb, may provide protection and enable scale establishment (Houston et al., 1979a). Conversely, the bark fungus Ascodichaena rugosa Butin was suspected Houston et al. (1979) to inhibit scale establishment. Bryophytes may play a role similar to that of lichens. Competitors for growing space with beech scale also include algae (Wainhouse and Gate, 1988) and fungi (Houston et al., 1979a). Bark infected by Neonectria fungi excludes beech scale (Houston and O'Brien, 1983).

Entomogenous fungi are found in the Zygomycota and Ascomycota (Ascomycetes and duerteomycetes) phyla. Cuticle degrading enzymes are important compounds used by fungi to breakdown host tissues and extracellular peptidases secreted by entomogenous fungi degrade organic materials in insect exoskeletons. Neonectria fungi have well known entomogenous relatives and their infection reportedly excludes further scale establishment (Gate, 1988), but the exclusion probably results from degradation of host tissue rather than parasitism of the scale. However, Verticillium lecanii Viegas is the only entomogenous fungus observed on beech scale or associated with collapsed populations (Lonsdale, 1983b; Gate, 1988). It only is associated with high scale densities and its effect on scale populations is not understood.

The beech scale has no known parasitoids (Gate, 1988). Predatory insects of the beech scale, Chilocorus spp. and Exochomus spp. (both Coccinellidae), are non-specific feeders associated with scale density and negligible as regulators (Mayer and Allen, 1983; Gate, 1988). The most notable insect predator of beech scales in North America is the twice-stabbed lady-beetle, Chilocorus stigma Say. (Mayer and Allen, 1983). The efficacy of this insect as a control for beech scale is limited by its failure to prey on all scale life stages, pension for dispersal, and an overwhelming scale reproductive rate (Mayer and Allen, 1983). A predatory Cecidomyid (Lestodiplosis sp.) preys upon all scale stages, but the feeding larvae are associated only with high scale density (Wainhouse and Gate, 1988). Less common predators include several other insects and mites (order Acari) which have even less impact on scale populations (Gate, 1988). A scale insect native to North America, Xylococculus betulae, is commonly hosted by yellow birch but feeds on beech bark and facilitates beech scale infestation by creating rough bark that provides protection (Shigo, 1962 and 1964). MacKenzie (2004) found more X. betulae on cankered beech than on disease-free beech in the Allegheny National Forest. Xylococculus 
betulae is prominent in areas with long histories of BBD and stands with a significant yellow birch population.

\section{Neonectria Fungi}

\section{Classification}

Neonectria fungi are classified as Ascomycetes. The fungal phylum Ascomycota can be divided into two broad categories: deuteromycetes and Ascomycetes. Deuteromycetes are imperfect or asexual stages of fungi that may or may not have a known sexual state. Cloning produces mass amounts of genetically identical conidia (asexual spores) in deuteromycetes. Any given fungus in Ascomycota may have one to several asexual states and produce conidia of various morphologies. Microconidia are small, usually single-celled, single-nucleate spores. Macroconidia are larger, multi-celled, multi-nucleate spores. Commonly, microconidia and macroconidia are produced by the same deuteromycete. Asexual stages of Neonectria fungi are in the form group Moniliales, form family Moniliaceae. Sexual stages of Neonectria fungi are in phylum Ascomycota, class Sordariomycetes, order Hypocreales, family Nectriaceae.

\section{$\underline{\text { Anamorph Classification }}$}

All asexual stages of Neonectria fungi are Hyphomycetes in the form group Moniliales, form family Moniliaceae, genus Cylindrocarpon Wollenw. (Brayford et al., 2004; Mantiri et al., 2001; Rossman et al., 1999). These anamorphs are characterized by upright, phialidic, hyaline conidiophores that produce hyaline cylindrical microcondia and macroconidia with zero to three cells and three to eight cells, respectively.

\section{$\underline{\text { Teleomorph Classification }}$}

Wollenweber (1917) first described the genus as he studied the fungus Neonectria ramulariae. Several Neonectria species were originally included in the genus Nectria (Fr.) Fr. These species have since been recognized as distinct from those in genus Nectria based on morphology by Rossman et al. (1999). They also determined genera with Nectria-like ascocarps initially placed in the family Nectriaceae should actually be split into two families, Bionectriaceae and Nectriaceae.

Nectrioid fungi are described as having brightly colored generally superficial perithecia and phialidic anamorphs (Hirooka and Kobayashi, 2007). The genus Neonectria as described by Rossman et al. (1999) is characterized by superficial, uniloculate, red, and $\mathrm{KOH}+$ perithecia. While Cylindrocarpon anamorphs are unique to Neonectria, perithecial anatomy also distinguishes the genus from other Nectriaceae genera. Perithecial walls have 2-3 regions, are $\sim 50 \mu \mathrm{m}$ or more thick, and are smooth or slightly rough to warted. The outer region is composed of 10-15 $\mu \mathrm{m}$ diameter angular cells with walls $1.5-2 \mu \mathrm{m}$ thick. The middle region, if present, has thick-walled cells oriented perpendicular to the centrum and the inner region has hyaline, thinwalled, elongate cells. Asci are unitunicate, sessile, and fusiform to clavate with an apical pore and sometimes a refractive ring. Ascospores are hyaline, ellipsoid-to-fusiform, smooth, ornamented or striate and 2-celled with a single medial septum. Although Nectria ascocarp anatomy differs from Neonectria, perhaps most notably in wall thickness and by having hyaline 
or pigmented ascospores, their respective Tubercularia and Cylindrocarpon anamorphs are the key characteristics that separate the two genera. Tubercularia species may be coelmycetous or hyphomycetous. Phylogenetic analysis of mitochondrial small subunit ribosomal DNA supports the separation of Nectria and Neonectria (Mantiri et al., 2001; Brayford et al., 2004), but future analyses may modify this taxonomy.

\section{Taxonomic History}

The classification of Neonectria fungi seemingly has been in a constant state of flux. Lohman and Watson (1943) refined the work of Ehrlich (1934) and identified Nectria coccinea var. faginata Lohman, Watson, and Ayers as the primary fungal agent in the North American disease complex. Rossman et al. (1999) renamed it Neonectria coccinea var. faginata (NCF). Molecular charcteristics indicated NCF was more closely related to European Nectria spp. than native North American Nectria fungi and was likely introduced in concert with the beech scale, but NCF was only found in America and its true origin is unknown (Mahoney et al. 1999). The main BBD pathogen in European beech was considered to be Nectria coccinea var. coccinea (NCC) (Mahoney et al., 1999) but Nectria ditissima Tul. (ND) also was implicated.

Nectria galligena Bres. (NG) is a native North American species infecting many hardwoods but only rarely causing cankers on healthy American beech (Houston, 1994a). However, due to its ever present nature as a native organism NG is readily able to invade scale-infested beech bark in North America (Spaulding et al., 1936; Cotter and Blanchard, 1981). The first fungus to appear in the BBD complex in North America often was NG, but NCF can more efficiently invade and fruit in scale-infested bark (Perrin, 1983) and replaces NG as disease progresses in a stand (Houston 1994a). This take over by NCF has been seen repeatedly in northeastern stands over the last 30 years (Cotter, 1977; Houston, 1994b). Another native fungus, Bionectria ochroleuca (Schwein.) Schroers and Samuels (BO), has been associated with dead and dying trees and occasionally associated with NG in WV and PA (Houston and Mahoney, 1987). The anamorph of BO, Clonostachys rosea, formerly Gliocladium roseum (Houston, 2005), was the most ubiquitous isolate from stands sampled in the early stages of a fungal infection in NY and PA (LaMadeleine, 1973). This organism is not well understood and appears to be less pathogenic than NCF or NG (Houston, 2005).

Recently, all species known to be involved in BBD were placed in the genus Neonectria (Brayford et al., 2004; Mantiri et al., 2001; Rossman et al., 1999). As a result, NCF, NCC, ND, and NG were renamed Neonectria coccinea var. faginata, Neonectria coccinea var. coccinea, Neonectria ditissima, and Neonectria galligena, respectively. More recently, molecular and morphological studies by Castlebury et al. (2006) determined N. ditissima and N. galligena are actually the same trans-Atlantic organism now referred to as $N$. ditissima. Furthermore, NCF was found to be distinct from NCC and these varieties were elevated to species status as Neonectria faginata (NF) and Neonectria coccinea (NC) and determined to be native to North America and Europe, respectively (Castlebury et al., 2006).

\section{Biology and Life Cycle}

Ascomycetes have various types of ascocarps. Fungi in family Nectriaceae form perithecia, flask-shaped structures with an outer wall of sterile hyphae and an inner layer, the hymenium or 
fruiting layer, composed of sterile hyphae and asci. Perithecia come in many colors and sizes and may form singly or in aggregates with or without a stroma. Those formed by Neonectria fungi associated with BBD are red-dark red in color, 200-400 micrometers in diameter, and aggregate in groups of a few to 60 in a poorly or well developed stroma (Castlebury et al., 2006). Neonectria perithecia mature from fall-to-early winter or whenever conditions permit.

Alexopoulos et al. (1996) provides a detailed biological description of Ascomycetes that applies to Neonectria fungi. Spores are the resting and dispersal states of both deuteromycetes and Ascomycetes. Asexual reproduction by Cylindrocaropon spp. occurs through mitotic and blastic production of conidia (asexual spores) from homokaryotic hyphae. Conidia appear in dry clusters on non-pigmented, separate conidiophores (asexual fruiting bodies) from midsummer-to-fall. Ascospores (sexual spores) are formed in asci via free cell formation following mating between compatible strains of Cylindrocarpon. Mating is bipolar with only two alleles on one mating type gene

Conidia and ascospores are both haploid. Germination results in the growth of homokaryotic hyphae with simple septa that allow the migration of organelles from compartment to compartment. Compartments of the hyphae may contain one, two, or many nuclei. Growth occurs at the tips of hyphae and as they elongate organelles, including nuclei, are shuttled forward to younger compartments and older compartments become empty and inactive. Homokaryotic hyphae regenerate clonally via conidia and conidiophores. Fusion of compatible strains of hyphae creates the heterokayotic condition necessary for sexual reproduction. Heterokayosis also may arise from mutation and could lead to parasexuality. When karyogamy takes place in a heterokaryon a diploid state is restored. Heterokayosis also may arise from mutation and could lead to parasexuality which occurs when sloppy mitotic divisions of the diploid state result in crossing over or the random loss of a duplicated chromosome. Novel nuclear conditions other than diploid are created by parasexuality.

\section{Population Dynamics}

\section{$\underline{\text { Disease Development }}$}

Like most canker organisms Neonectria fungi are weak pathogens that take advantage of stressed hosts (Manion, 1991). Without scale infestation infection is severely limited. Drought and poor nutrition related to soil composition predispose beech to more severe Neonectria infection (Lonsdale, 1980).

The disease cycle of pathogenic fungi is well understood, following distinct stages of development. Inoculation is the bringing together of inoculum, in the form of a conidium, spore, or mycelial fragment, and host. Any wound generated mechanically, or by biota or enzymatic activity can permit entry into a host, or the pathogen may penetrate host tissues using an infection peg and appressorium. Infection is established once host nutrients are obtained, followed by an incubation period that proceeds until symptoms or signs are generated on the host. Invasion then follows as the pathogen spreads throughout a host. To complete the cycle reproduction occurs on the host and inoculum is produced for further dissemination. Overwintering is a resting stage of pathogens that can occur at any part of the cycle. 


\section{$\underline{\text { Dispersal }}$}

The inocula dispersed by deuteromycetes and Ascomycetes are immobile conidia and spores. Local and long-range dispersal is entirely passive and predominately wind generated given the high surface area-to-mass ratios of fungal spores. Water may splash inocula into wind currents or spread it in a stand. The patterns of particulate dispersion described above (Raynor et al., 1974) hold true for insects and fungal spores alike. As with insects and plant material local and long distance dispersal of inocula is facilitated by humans and phorecy, the latter particularly when highly mobile insects come in contact with fungal inocula.

The constant influence of environment is a significant aspect of fungal population dynamics. Climate dictates temperature and available moisture, both must be in an ideal range for successful fungal growth. The ranges of hosts and pathogens also are under this control, and fungi have greater plasticity than their hosts in range of operation. Most fungi prefer one of three temperature/moisture regimes to perform their duties: hot and dry, warm and moist, or cool and wet. Neonectria fungi prefer cool, moist conditions found in temperate regions.

\section{Impacts of Beech Bark Disease}

The greatest impacts of BBD are an increase in beech mortality and an increase in coarse woody debris (CWD). McGee (2000) reports old growth and even-aged northern hardwood stands unaffected by BBD have proportionally lower volumes of CWD and fewer snags than similar stands impacted by BBD. Overall above ground biomass decreased in a diseased northern hardwood stand and sugar maple biomass increased as beech experienced high mortality, but additions of beech material to the forest floor did not lead to changes in nutrient cycling (Forrester, et al., 2003). However, changes in beech diameter classes or species composition could reduce beechnut production and affect nutrient cycling (Lovett et al., 2006).

Proportions of beech normally increase in northern hardwood stands without disturbance as beech typically out-competes associates like sugar maple and red maple (Acer rubrum L.) (Twery and Patterson III, 1984). Disturbance created by BBD in northern hardwood stands removes beech and opens gaps for other species but beech persists partly due to sprouting (Twery and Patterson III, 1984; Gavin and Peart, 1993; Griffin et al., 2003). Yellow birch will readily recruit small gaps created by biotic disturbance but does not respond well to sudden release (Forcier, 1975). Its proportions will decline as sugar maple or other more tolerant species occupy space, resulting in minimal changes in species composition (Twery and Patterson III, 1984).

Cucumber magnolia (Magnolia acuminata L.), black cherry, and sugar maple are replacing beech in the canopy of diseased stands in the Monongahela National Forest (MNF) (MacKenzie, 2004) and increases in importance of sugar and red maples and red oak in a conifer-hardwood forest affected by BBD have been recorded (Runkle, 1990; Lovett and Mitchell, 2004). Tolerant conifers are recruited into gaps in conifer-hardwood stands. Red spruce (Picea rubens Sarg.) is replacing beech in the understory in the MNF (MacKenzie, 2004), hemlock (Tsuga canadensis (L.) Carr.) often increases in importance with the loss of beech (Twery and Patterson III, 1984; Runkle, 1990; LeGuerrier et al., 2003), and the potential exists for beech and yellow birch to be 
entirely replaced during the generation of pure hemlock stands (Twery and Patterson III, 1984). However, beech likely will persist under all these scenarios through root sprouting.

MacKenzie (2004) and Morin et al. (2007) predict resistant beech will maintain a beech component in northern hardwood forests but mast production for wildlife will be altered. American beech is an important resource for wildlife. The foliage and bark of beech present habitat and foraging opportunities for insects, birds and mammals. Black bear and marten populations may be adversely affected by reductions in beech mast. Black bear reproduction increases following years of high beechnut production, and marten kit production and survival is thought to be improved with bumper beechnut crops (Jakubas et al., 2005). The impacts of BBD on wildlife are only now being investigated.

\section{Management of Beech Bark Disease}

Eradicating BBD causal agents or beech are not realistic goals and management of the disease is the standard response where applicable. Chemical controls, dormant oils and pressure washing can save historically valuable individual trees from scale attack (Mielke et al., 1986), and insect or fungal predators may have the potential to be developed as biocontrol agents (Houston, 1983; Lonsdale, 1983b; Mayer and Allen, 1983) but managing BBD focuses on reducing susceptible trees and identifying and increasing resistant trees (Mielke et al., 1986; Burns and Houston, 1987). The ultimate goals are to reduce losses of beech and regenerate healthy beech in diseased and disease-free stands. Silvicultural management can reduce the impacts of BBD, and it is important to tailor methods to site conditions and desired outcomes. The first step in a sound management strategy is to determine the levels of beech scale and Neonectria in the stand and what values (i.e. wildlife, recreation, production) are most important. Monitoring for beech scale and Neonectria fungi helps develop timetables for predicting heavy losses and planning management activities for all the stages of BBD (Mielke et al., 1986; Heyd, 2005).

Some guidelines have been developed managing for BBD at its various stages or on a general basis. In stands threatened by scale infestation and advancing fronts with a dense beech component, this species should be thinned to reduce scale spread and maple or oak associates favored to improve value and species diversity (Heyd, 2005). Large, over mature trees preferred by beech scales that could nurture populations and become an inoculum source for the stand should be removed (Houston et al., 1979a; Mielke et al., 1986). Heyd (2005) suggests thinning to a basal area of 70-100 $\mathrm{ft}^{2}$ leaving smaller diameter class beech that are presumably less susceptible to disease while maintaining some large beech for wildlife. Smooth barked beech should be retained and beech with an abundance of wounds that would create favorable habitat for scale should be removed (Mielke et al., 1986; Burns and Houston, 1987; Heyd, 2005). Vigorous beech compartmentalize wounds quickly and their thicker phloem protects the cambium from Neonectria infection (Burns and Houston, 1987) so they should be favored. Moving salvaged firewood into or out of advancing fronts should be avoided, especially from late summer to early fall when beech scales are mobile (Heyd, 2005).

In all areas affected by BBD, unhealthy, decayed, dead and heavily infested or infected beech should be salvaged and lightly or unaffected trees retained; herbicide treatments may eliminate susceptible advanced regeneration. Retaining lightly infested beech potentially expressing partial resistance and scale-free beech are important for improving the fitness of a stand (Mielke et al, 
1986). In killing fronts and aftermath zones, resistant beech will sprout but be less numerous than dead susceptible beech; removing all sprouts within $1.5 \mathrm{~m}$ of dead beech may quickly increase the resistant gene pool in a stand (MacKenzie, 2004). In aftermath zones particular attention should be paid to removing beech thickets and clearcuts may be appropriate if there are few if any remaining healthy beech (Ostrofsky and Houston, 1989). Scale infestation normally is innocuous to beech if there are light infestations not leading to Neonectria infection. Guidelines developed by Burns and Houston (1987) for stands long affected by BBD suggest removing beech with sunken cankers, to minimize future loss to defect that could be hidden as trees grow over wounds, and retaining scale-free and lightly infested trees with minimal defect or raised lesions. Smooth barked beech with no cankering should be favored and maintained as crop trees and a source for the next generation. Monocultures should be avoided. Overall stand health and vigor of all species should be maintained by harvesting wounded, poorly crowned, and deformed trees and avoiding overstocking.

General strategies for uneven-aged management in diseased stands include various harvesting regimes and selection criteria based on management objectives. Timely harvests at $\sim 10$ year intervals favoring commercial species other than beech can improve stand health and value; selection can be modified based on site conditions and forest floors scarified to discriminate against weed and nuisance species (Filip, 1978). When mast for wildlife is important and defect is acceptable, strip clearcuts can be applied with large, seed producing, potentially resistant trees retained in the uncut strips (Ostrofsky and Houston, 1989). Shelterwood cuts combined with herbicide treatment of regeneration have been effective for rehabilitating stands (Ostrofsky and McCormack, 1986). Group selection combined with single-tree removal increased more valuable sugar maple and hemlock components, and lead to improved growth in residual trees and quality of timber (Filip, 1978). Group harvests of overmature, defective, dying, and dead trees alternated with single-tree selections can salvage beech and manipulate stand structure (Leak and Filip, 1977).

Yellow birch is a unique associate of beech in that it is a common host of $X$. betulae, another bark feeding pest of beech and potential factor in BBD spread. Shigo $(1962,1964)$ notes $X$. betulae is capable of providing habitat for beech scales. It also could provide infection courts for Neonectria fungi in beech and yellow birch. Discrimination against the latter when harvesting might have an effect on $X$. betulae populations and the progression of BBD. Single-tree selections of unhealthy and defective beech and yellow birch over a 50 year period resulted in less than $20 \%$ infected beech basal area while an unmanaged neighboring stand had more than $60 \%$ infected basal area. In another nearby stand, unmanaged since one beech scale control thinning 50 years earlier, over $60 \%$ of the beech basal area was not infected. Prior to management $80-90 \%$ of beech in these stands had Neonectria infection, indicating that the preferential harvesting of unhealthy yellow birch with beech may reduce disease incidence (Leak, 2006).

As noted above the impacts of BBD may lead to less beech in some stands. More often prolific beech sprouting from stumps, and particularly roots, can be problematic following harvest. Salvage logging of beech in New England led to widespread root sprouting producing beech thickets rendered defective by BBD (Houston, 1975). Harvesting operations should be very careful to avoid root damage that could encourage root sprouting and the growth of beech thickets (Ostrofsky and Houston, 1989; Heyd, 2005). Track-mounted swing-to-bunch feller- 
bunchers and carefully marked skid trails for traditional cable skidding can minimize root damage (Ostrofsky and Houston, 1989). The many trails made by drive-to-tree feller-bunchers can damage roots excessively (Ostrofsky et al., 1986).

Beech scales have natural enemies that may have potential as biocontrol agents. The twicestabbed lady beetle, Chilocorus stigma, is native to North America and feeds on beech scales (Mayer and Allen, 1983). A close relative of C. stigma, the multicolored Asian lady beetle (Harmonia axyridis), is a generalist predator known to prey on adelgids (Flowers et al., 2005), which are sapfeeding insects similar to the beech scale in habit and morphology. Harmonia axyridis has been widely released as an exotic biocontrol agent (Koch and Galvan, 2008). If it could be determined that one of these two beetles, or their relatives, are effective predators of beech scales they may be able to prevent epidemics that lead to heavy mortality and long term damage if released in threatened scale-free stands or advancing fronts. Realistically, the logistics of rearing a population of generalist predators that would be poor biocontrol candidates for such a release is impractical.

The entomogenous fungus Verticillium lecanii is associated with high scale densities (Gate, 1988) and its effects on beech scale populations are not understood, but it has been used as a biocontrol for Coccus hesperidium (Coccidae) (Samsinakova and Kalalova, 1975) and other insects (Alavo and Accodji, 2004; Palande and Pokharkar, 2005). A fungal parasite is immobile and may be deployed with relatively site-specific dispersal depending on the time and method of application and its reproductive capabilities may compete with scale reproduction enhancing their efficacy as a control relative to predatory insects.

Gonatorhodiella highlei is a contact mycoparasite (obligate biotroph) of Neonectria fungi. Distinct buff colored patches of $G$. highlei on grey beech stems may be used to detect the presence of Neonectria before cankers are evident. Gain and Barnett (1970) found colonies of Neonectria could be overgrown by G. highlei with negligible harm to the former on various agar media (Gain and Barnett, 1970). However, in personal investigations by this author with potatodextrose agar, the size of Neonectria colonies paired with G. highlei was statistically smaller ( $\mathrm{p}<$ 0.001 ) than solo colonies after 20 days. The interactions of these fungi in nature and efficacy of G. highlei as a biocontrol have not been fully explored.

\section{Beech Resistance to Beech Bark Disease}

\section{$\underline{\text { Inherited Resistance }}$}

For many years some beech has been observed to escape both signs and symptoms of disease (Ehrlich, 1934; Shigo, 1962 and1964; Wainhouse and Howell, 1983; Houston, 1983). Neonectira infection and BBD are largely a function of beech scale infestation. Resistance studies of clonal European beech reveal genetic control of beech scale resistance (Wainhouse and Howell, 1983). Challenge trials with beech scale have shown some North American beech can resist scale infestation (Houston, 1982 and 1983). A small percentage of American beech populations ( 1$5 \%$ ) are estimated to remain asymptomatic following years of disease incidence (Houston, 1983). Challenge trials suggest resistance to beech scale is responsible (Houston, 1982, 1983). Studies indicate resistance to scale infestation can be inherited (Koch and Carey, 2005; Koch et al., 2010). Trees resistant to beech scale have close relationships, suggesting genetic control. Half-sib beech 
families with just one scale-free parent exhibit low levels of resistance relative to full-sib families from two un-infested parents (Koch et al., 2010). Susceptibility to infestation appears to be the dominant trait, or other quantitative factors are involved in resistance.

Inherited resistance is expressed as gene products or physical attributes of a host enable it to deter or tolerate pests. Antibiosis is a genetically controlled chemical disruption of insect physiology: the performance of the pest is reduced (Painter, 1951, 1958). Antixenosis is a genetic resistance that physically or chemically deters feeding or oviposition by a pest: the behavior of the pest is affected (Painter, 1951, 1958). European beech expressing resistance have more extensive regions of thick, lignified cells relative to susceptible trees (Lonsdale, 1983a). This may be an example of antixenosis and physical deterrence based on the inability of scales to penetrate bark cells. Tolerance is a type of condition where plants can withstand a given level of attack, and still grow and reproduce, that would damage a susceptible host (Painter, 1951, 1958). For example, an oak can produce many more acorns than needed and tolerate acorn weevil infestation to still produce the next generation.

Beech surviving BBD in Europe and North America are potentially genetically resistant, but in naturally regenerating beech stands variations in tree population dynamics may render these individuals susceptible in the future as the beech scale adapts to specific host genetics.

(Wainhouse and Gate, 1988).

\section{Ecological Resistance}

Ecological resistance is a mechanism, not related to gene expression, that sometimes defends plants from insects. Ecological resistance is a non-inherited pseudoresistance of plants to insects derived from the effects of environmental conditions more so than genetics. It is a temporary condition appearing randomly with little or no relation to co-evolution of host and pest and could occur in three ways: host evasion, host escape, and induced resistance (Panda and Kush, 1995; Medigo and Rice, 2006). Hosts can evade infestation with a reduced exposure time to potential inoculum. Early planting and crop rotations evade damaging insect life cycles in agricultural systems. Host escapes seemingly occur by pure chance when a susceptible host in an affected population remains un-affected. Escapes are poorly understood. Induced resistance occurs when the environment or plant ecology limit insect infestation.

Distinct from constitutive defenses that are ever-present, an induced defense occurs when a host responds to an environmental condition and is temporarily rendered unfavorable for infestation. Transient environmental factors such as interspecific competition or changes in nutrient cycles may temporarily induce resistance, or conversely, induce susceptibility, of trees to pests and pathogens (Bonello et al., 2006); these induced defenses can be localized or systemic (Eyles et al., 2010). In the BBD complex, decay fungi have been shown to limit scale establishment, perhaps due to induction of chemical pathways in response to decay (Cale et al., 2015). Genetic resistance can be partial and variable with the numbers of genes involved and their level of expression, whereas ecological resistance is variable as determined by biotic and abiotic factors.

The factors that influence ecological resistance also regulate what Holling (1973) refers to as resilience, which is the ability of a natural system to recover from disturbance and maintain persistent relationships among system components. Resilience is inversely related to stability: 
resilient systems have low stability (Holling, 1973). Stable systems have little fluctuation in levels of various components and can be severely disrupted by disturbance; whereas resilient systems have wide fluctuations and absorb changes induced by disturbance with limited disruption of relationships (Holling, 1973). The fluctuating, somewhat chaotic, nature of components in a resilient system allows the flexibility to withstand disturbance. The characteristics that render a system resilient may improve the ability of a host to react to attack and ecological resistance may well be an end result of resilience.

Variations in stand ecology and stand development may favor disease-free trees and the development of different phases of the disease in North America that contrast with the gap dynamics observed in BBD affected stands in Europe. Most of the environmental characteristics influencing beech scale infestation could be considered factors for induced resistance, and the scales themselves may even induce a resistance.

\section{Factors Potentially Influencing Ecological Resistance}

When exploring ecological resistance in American beech, factors affecting both beech scale and Neonectria fungi must be considered, even though scale establishment is most important for disease development. Forest professionals have noticed variations in the progression of BBD for many years. Management guidelines for promoting reductions in BBD based on stand structure have been previously described. Some pre-existing stand and site features that limit BBD could be considered a form of ecological resistance. Houston et al. (2005) studied disease progression on numerous plots in the northeast with a history of BBD of 50 years or more. Data from most plots suggested disease spread followed the existing model of advancing, killing, and aftermath stages. However, several plots suggested a deviation from typical BBD progression.

One plot in the Houston et al. (2005) study, in particular, experienced a delay in disease outbreak although causal agents had been present for over 20 years. Two other plots from that study located within two miles of each other exhibited markedly different levels of scale infestation, Neonectria fruiting, and beech mortality. Genetic resistance could not explain the slow progression of BBD since causal agents were not completely absent and scale-free beech appeared in numbers comparable to that expected from genetic resistance. Houston et al. (2005) proposed deviations in disease progression on these plots were a function of site conditions. Although BBD was present, the progression to a killing front or an aftermath stage had been delayed. Personal observations by this author include groups of scale free trees in stands affected by BBD for more than 20 years. Some of these groups have beech with minimal scale infestation, suggesting partial genetic resistance involving multiple genes, but ecological factors also may responsible.

Dense stands with low canopies may favor infestation. In European beech plantations of varying age, mortality from BBD was highest where there was competition related stress (Parker, 1983). Dense, pure stands in Europe experienced most severe disease during drought, especially where chalk under thin soil profiles was well drained (Lonsdale, 1980; Perrin,1983; Parker, 1983).

Scales and Neonectria inoculum settle where wind patterns take them. Wind patterns may sweep BBD inoculum over trees at higher elevations on steep slopes on the leeward side of ridge tops and deposit them farther down slope. Many scale-free trees have been observed on ridge tops 
while other portions of the stand down slope have severe BBD infection. Houston et al. (1979a) found less mortality on upper or lower slopes and increased mortality on mid slopes, and gentle slopes generally had less scale infestation. Also, Ehrlich (1934) observed stands on broad ridge tops that experienced less scale infestation relative to stands on steep slopes. Exposed trees showed less infestation relative to trees at stand interiors. In some stands beech scales seem to prefer tree aspects based on exposure to wind, sun, and rain (Ehlrich, 1934; Houston, 1983). This could project to the stand level with certain aspects favoring infestation. Certain topographic locations may favor or inhibit scale establishment, particularly relative to prevailing winds.

Early work regarding BBD in North America during the beginning of the $20^{\text {th }}$ century focused on describing the complex and its components, its effects on American beech, and to some extent identifying limiting factors (Felt, 1933; Erhlich, 1934; Brower, 1949). After that BBD research was lacking as forest mangers generally looked upon the complex as beneficial, removing an unwanted "weed" species from the landscape when thickets did not form. However, more recently, as the ecological importance of all species has been recognized, there has been a mild resurgence in BBD research and interest in preserving beech on the landscape. Research on characterization, resistance, impacts, and possible management of BBD has been described above. There also has been limited work on the environmental factors influencing BBD.

\section{Chapter 2: Study of Ecological factors}

\section{Hypothesis and Objectives}

This research is based on the hypothesis that some disease-free American beech exhibit ecological resistance, a transient condition related to environmental factors that influence beech scale attack and/or Neonectria infection. The beech bark disease (BBD) complex involves the dynamic interactions of numerous biotic and abiotic factors. Resistance to scale infestation by American beech (Fagus grandifolia Ehrh.) is a heritable trait; however, a variety of ecosystem factors may influence the incidence and severity of BBD. The absence of BBD symptoms or signs on an individual tree does not imply genetic resistance. Specific objectives are to:

1. Examine stand features including incidence severity and longevity of BBD, species composition, stand density, and canopy features;

2. Evaluate forest floor components including soils, coarse woody debris, litter layer, understory, and the presence of mycorrhizal fungi, and;

3. Record landscape and topographical features including climate, slope, aspect, and elevation.

\section{Study Sites}

Sites were selected based on the following criteria: 1. had to have a history of BBD, meaning stands must represent killing fronts or aftermath zones, and; 2. component of disease-free beech had to be present. Meeting these requirements was not always easy but was facilitated by communication with forest health professionals and extensive investigation of stands with a 
beech component. Fifteen Appalachian hardwood stands with a several-decades long history of BBD and a component of disease-free beech were identified (Table 1). A total of 102 plots were sampled. Shapefiles of beech distributions on each plot were acquired with a Magellan Mobilemapper ${ }^{\mathrm{TM}}$ CE (Magellan Corp., Deerfield, IL) and uploaded into ArcMap. Satellites for mapping were not available while at the Holden Arboretum site. A regional map showing locations of sites can be seen in Appendix 1, Figure 1. Shapefiles were combined with topographic map layers to produce detailed digital maps of each site that indicate beech scale and Neonectria ratings for each beech (Appendix 1). Maps for the Holden Arboretum were produced manually in ArcMap and only represent mean infestation and infection at the site, not distributions of beech on each plot.

Table 1: Study sites in the Appalachian region.

\begin{tabular}{|c|c|c|}
\hline Location & Number of Plots & Appendix 1 Maps \\
\hline Allegheny National Forest, PA & 5 & Figures 2, 3 \\
\hline Beverly, WV I & 5 & Figures 4,5 \\
\hline Beverly, WV II & 5 & Figures 6,7 \\
\hline Blackwater Falls State Park, WV I & 7 & Figures 8,9 \\
\hline Blackwater Falls State Park, WV II & 6 & Figures 10,11 \\
\hline Blackwater Falls State Park, WV III & 5 & Figures 12,13 \\
\hline Cranberry Wilderness, WV & 6 & Figures 14,15 \\
\hline Dolly Sods Recreation Area, WV I & 5 & Figures 16,17 \\
\hline Dolly Sods Recreation Area, WV II & 5 & Figures 18,19 \\
\hline Gaudineer Scenic Area, Monongahela National Forest, WV & 10 & Figures 20,21 \\
\hline Great Smoky Mountains National Park, TN & 8 & Figures 22,23 \\
\hline Holden Arboretum, Kirtland, OH & 5 & Figures 24,25 \\
\hline Kumbrabow State Forest, WV & 10 & Figures 26,27 \\
\hline Middle Mountain, Monongahela National Forest, WV & 10 & Figures 28,29 \\
\hline Shaver's Fork Recreation Area, Monongahela National Forest, WV & 10 & Figures 30,31 \\
\hline
\end{tabular}

\section{Methodology}

\section{Field}

\section{Plot Establishment}

At each study site circular 0.04-hectare plots were established on northeast-southwest parallel transects. Plot centers were placed about 80-100 $\mathrm{m}$ apart, starting from a randomly selected point in a stand with disease-free beech. Transects had two-five plots and were approximately $100 \mathrm{~m}$ apart. Variations of this design where employed as necessary based on terrain or to include beech in study plots. Plot boundaries were marked in cardinal directions with pin flags. Plot centers also where marked. Data collection began using ten plots, but early on it was realized the extensive nature of sampling was extremely time consuming and limiting the number of plots on a given site was necessary to effectively manage time. Variances for five and ten plots were calculated from selected parameters estimated at the Shaver's Fork and Gaudineer sites. Twotailed F-tests indicated no statistically significant differences in parameters between five and ten plots (Table 2). Therefore, subsequent sites were sampled with five plots; more than five plots were established whenever time permitted. Accordingly, Blackwater Falls State Park, which was originally sampled as one site with thirteen plots, was considered two distinct sites; a ridge top with six plots and a mid-slope with seven plots. 
Table 2: Two-tailed F-test variance ratios $\left(F=\sigma^{2}{ }_{1} / \sigma^{2}{ }_{2}\right)$ and $p$-values of five plots vs. ten plots for selected parameters measured at Shaver's Fork and Gaudineer sites.

\begin{tabular}{lcc}
\multicolumn{1}{c}{ Parameter } & Shaver's Site $\left(\mathrm{F}=\sigma^{2}{ }_{1} / \sigma_{2}^{2}\right)$ & Gaudineer Site $\left(\mathrm{F}=\sigma^{2}{ }_{1} / \sigma_{2}^{2}\right)$ \\
\hline Trees per hectare & $1.84^{\mathrm{a}} ; \mathrm{p}=0.58$ & $1.06^{\mathrm{a}} ; \mathrm{p}=0.86$ \\
Basal Area per hectare & $1.23^{\mathrm{a}} ; \mathrm{p}=0.90$ & $1.17^{\mathrm{a}} ; \mathrm{p}=0.77$ \\
Beech per hectare & $1.61^{\mathrm{a}} ; \mathrm{p}=0.68$ & $1.12^{\mathrm{a}} ; \mathrm{p}=0.81$ \\
Beech Basal Area per hectare & $1.68^{\mathrm{b}} ; \mathrm{p}=0.48$ & $1.17^{\mathrm{a}} ; \mathrm{p}=0.77$
\end{tabular}

${ }^{\mathrm{a}} \mathrm{F}_{0.025,9,4}=8.90 ;{ }^{\mathrm{b}} \mathrm{F}_{0.025,4,9}=4.72$.

\section{Stand Features}

Canopy density was estimated at several points in a plot using a concave spherical densiometer (Robert E. Lemmon, FOREST DENSIOMETERS Bartlesville, OK) and basal area (BA) estimated from plot center using BAF $10\left(\sim 1 \mathrm{~m}^{2} /\right.$ acre BA). A TruPulse $360^{\circ}$ laser rangefinder (Laser Tecnology Inc., Centennial, CO) was used to establish distances from plot centers. Total height, canopy class, and diameters were recorded for all beech $>5 \mathrm{~cm}$ diameter at breast height (DBH) and non-beech $>10 \mathrm{~cm}$ DBH. Coordinates (decimal degrees, WGS 1984) and elevations of all beech stems were recorded with a Mobilemapper ${ }^{\mathrm{TM}} \mathrm{CE}$. The slope and aspect of each plot were recorded.

Coarse woody debris was measured on $13 \mathrm{~m}$ transects from plot center to the north and east boundaries. Diameter, species (if known), and decay level were recorded for debris crossing transects and greater than $1 \mathrm{~cm}$ diameter. All standing dead stems and stumps $>10 \mathrm{~cm}$ were counted as standing CWD (SWCD) and their height, species (if known), diameter measured at breast height or the stump's highest point, and decay level recorded. Debris decay was recorded at four levels; sound wood with or without bark (1), sapwood decayed (2), sapwood and some heartwood decayed (3), or decayed throughout (4).

Circular subplots were used to sample regeneration, litter, herbaceous layers, and soils. Subplot boundaries were temporarily established halfway from plot center to plot boundary in each cardinal direction using a $2 \mathrm{~m}$ diameter plastic hoop. Species and number of tree seedlings and saplings, herbaceous species, litter depth, and dominant species of leaf litter within the subplot boundary were recorded. A 1-inch soil auger was used to collect 12-18 inch cores used to estimate soil types based on the Munsell color system.

\section{Cryptococcus Infestation and Neonectria Infection Ratings}

Cryptococcus infestation and Neonectria infection were rated separately on four sides of each beech using a qualitative five-category rating system of no infestation/infection (0), trace infestation/infection (1), light infestation/infection (2), moderate infestation/infection (3), or heavy infestation/infection (4). Detailed descriptions are given in Table 3. Each category represents a range of infestation/infection; images of each category were taken and used to develop a quick-reference guide for evaluating individual beech stems (Appendix 2). Images of zero ratings were not included as they represent healthy beech with no evidence of beech scale infestation or Neonectria infection. 
Table 3: Descriptions of Cryptococcus infestation and Neonectria infection categories.

\begin{tabular}{|c|c|c|}
\hline Category & Cryptococcus & Neonectria \\
\hline 0 & $\begin{array}{l}\text { No beech scale evident; tree initially } \\
\text { looks clean and scale(s) NOT evident } \\
\text { upon close inspection; hands lens may } \\
\text { be needed to confirm }\end{array}$ & $\begin{array}{l}\text { No Neonectria evident; tree initially looks } \\
\text { clean and canker(s)/perithecia NOT } \\
\text { evident upon close inspection; hands lens } \\
\text { may be needed to confirm }\end{array}$ \\
\hline 1 & $\begin{array}{l}\text { Trace scale population; tree initially } \\
\text { looks scale-free but infestation evident } \\
\text { upon close inspection, hands lens may } \\
\text { be needed to confirm }\end{array}$ & $\begin{array}{l}\text { Trace Neonectria; tree initially looks } \\
\text { infection-free but cankers or perithecia } \\
\text { evident upon close inspection; hands lens } \\
\text { may be needed to confirm }\end{array}$ \\
\hline 2 & $\begin{array}{l}\text { Beech scale clearly evident from a } \\
\text { short distance; scales singular or } \\
\text { uniformly dispersed in clusters; } \\
\text { majority of stem scale-free }\end{array}$ & $\begin{array}{l}\text { Cankers/perithecia clearly evident from } \\
\text { short distance; few scattered or clusters of } \\
\text { cankers; majority of stem infection-free }\end{array}$ \\
\hline 3 & $\begin{array}{l}\text { Beech scale clearly evident from a } \\
\text { short distance; scales singular or } \\
\text { uniformly dispersed AND in small } \\
\text { clusters OR many clusters of scales; } \\
\text { majority of stem may or may not be } \\
\text { scale-free }\end{array}$ & $\begin{array}{l}\text { Cankers/perithecia clearly evident from } \\
\text { short distance; cankers litter large portion } \\
\text { of stem; majority of stem likely cankered; } \\
\text { streaks may appear; bark may be peeling } \\
\text { off in small sections }\end{array}$ \\
\hline 4 & $\begin{array}{l}\text { Beech scale clearly evident from short } \\
\text { distance; large clusters of scales all } \\
\text { over stem; majority of stem likely } \\
\text { infested }\end{array}$ & $\begin{array}{l}\text { Cankers/perithecia clearly evident from } \\
\text { short distance; cankers affect nearly entire } \\
\text { stem; multiple streaks; bark may be peeling } \\
\text { off in small sections; tree dead? }\end{array}$ \\
\hline
\end{tabular}

Categories of scale infestation were developed with field observation and laboratory examination of beech bark samples. To estimate scale populations bark samples measuring $6.5 \mathrm{~cm}^{2}$ were collected in the field with a hammer and chisel. Beech scale ratings were quantified in the lab as described below. Categories of Neonectria infection were developed only with field observation of beech at Blackwater Falls I and II. Neonectria ratings were quantified by estimating the mean number of cankers per $0.5 \mathrm{~m}^{2}$ of stem on ten trees from each category. Any portion of a tree in each category may have no beech scales or Neonectria cankers at all and each category represents an estimated mean per unit surface area.

\section{Bark Organisms}

Beech stems in each plot also were examined for lichens, insects, or fungi. Bark samples with Neonectria perithecia were collected for laboratory examination and processing. Samples were collected with a $1.3 \mathrm{~cm}$ diameter leather punch from three beech within each plot or nearby if necessary. Severely cracked, blocky, or blistered bark was sampled using the same methodology. 


\section{Laboratory}

\section{Cryptococcus Infestation Ratings}

Bark samples collected from Shaver's Fork and Gaudineer and measuring $6.5 \mathrm{~cm}^{2}$ were examined using a Leica EZ 4 stereoscope (Leica Microsystems Inc., Buffalo Grove, IL). Ten bark samples were examined for each scale infestation category. The qualitative field rating only included observation of wax tufts produced by adult beech scales. Therefore, the number of adults under tufts on each bark sample was counted, but not crawlers or eggs.

\section{Neonectria Samples}

Neonectria samples recovered from bark plugs were identified to species using ascospore morphology as described by Castlebury et al. (2006). Perithecia were slide mounted in water under a Leica EZ 4 stereoscope (Leica Microsystems Inc., Buffalo Grove, IL) and ascospores viewed at 400x-1000x magnification with a Nikon Eclipse E600 light microscope (Nikon Instruments Inc., Melville, NY). Perithecia and bark tissues, sampled from plugs with a bone biopsy tool were surface sterilized in $0.615 \%$ sodium hypochlorite for 5-10 minutes and placed on Difco ${ }^{\mathrm{TM}}$ potato dextrose agar to isolate Neonectria species and other fungi. The 18S rRNA, ITS1, 5.8S rRNA, ITS2, and 28S rRNA regions of selected isolates identified using ascospore morphology were amplified with PCR. Amplified DNA products were shipped to Davis Sequencing in Davis, CA for sequencing. Comparison of sequences from selected isolates to known sequences confirms this identification.

\section{$\underline{\text { Statistical Analyses }}$}

\section{Cryptococcus Infestation and Neonectria Infection Ratings}

Regression was used to evaluate the relationships between the qualitative visual ratings used in the field and estimated numbers of beech scale on $6.5 \mathrm{~cm}^{2}$ bark squares or cankers per $0.5 \mathrm{~m}^{2}$. Estimates were plotted as the dependent variable against beech scale and Neonectria categories and a line fitted in Excel 2010 (Microsoft ${ }^{2}$, Redmond, WA). The mean number of scales on a $6.5 \mathrm{~cm}^{2}$ bark sample and cankers per $0.5 \mathrm{~m}^{2}$ estimated for each category were extrapolated to estimates of sample populations for each beech observed in the field using the surface area of a cylinder as the surface area $\left(\mathrm{cm}^{2}\right.$ for Cryptococcus, $\mathrm{m}^{2}$ for Neonectria) of the first $2.4 \mathrm{~m} \log$ (SA $=2 \pi \mathrm{rh}$; where $\mathrm{r}=0.5(\mathrm{DBH})$ and $\mathrm{h}=2.4384)$. The infestation or infection ratings for plots were calculated as the mean estimated scale population or number of cankers per beech tree.

\section{Field Data}

\section{$\underline{\text { Descriptive Statistics }}$}

An Excel 2010 database was compiled from field sampling. Descriptive statistics were used to evaluate incidence and severity of scale infestation and Neonectria infection and stand features including species composition. All parameters were recorded as plot data (Appendix 3, Table 1) 
and site data, converted to numerical form when necessary, and used as independent variables in multivariate analyses using infestation and infection as responses.

Proportions of beech with a given infestation or infection rating, or both, were calculated in Excel as a percent of total beech sampled. Mean ratings of infestation and infection for individual beech were rounded to the nearest whole number to fit each tree into a category. Individual stems also were evaluated using a combination of scale infestation and Neonectria infection.

Incidence and severity of causal agents on plots was estimated from proportions of beech with each infestation or infection rating. Species compositions in each scale infestation and Neonectria rating were calculated from the mean of each species. The infestation or infection ratings for plots were calculated as the mean estimated scale population or number of cankers per beech tree.

Percent dominant, co-dominant, intermediate, and suppressed individuals for each tree species were calculated as a proportion of total stems. Species diversity was calculated with the Shannon-Wiener index, $\mathrm{H}=-\sum \mathrm{p}_{i} \ln \mathrm{p}_{i}$ (Shannon and Weaver, 1948) where $\mathrm{p}_{i}$ is the proportion of the $i$ th species. The similarity in abundance of each species, or evenness (E), was calculated by dividing the Shannon-Wiener index $(\mathrm{H})$ by the natural $\log$ of species richness $(\mathrm{S}):(\mathrm{E}=\mathrm{H} / \mathrm{lnS})$, where richness is the total number of species.

Volumes of CWD were calculated as cubic meters per hectare for each plot with a line intersect sampling formula $\left(\mathrm{V}=\left(\pi^{2} 10000 / 80000 \mathrm{~L}\right)\left(\sum \mathrm{d}^{2}\right)\right)$ where $\mathrm{L}=$ length of sample line in meters and $\mathrm{d}=$ diameter in centimeters of woody debris intersecting the sample line. Standing CWD volumes were calculated as volumes of a cylinder $\left(\mathrm{V}=\pi \mathrm{r}^{2} \mathrm{HT}\right)$ in cubic meters, summed, and converted to cubic meters per hectare. Percent of species comprising CWD and SCWD were calculated as proportions of total volume. Climate data were gathered from the National Oceanic and Atmospheric Administration National Weather Service website (http://www.weather.gov/) and represent annual means from 1981-2010 (Appendix 3, Table 2). Growing degree days (GDD) on the NOAA website are calculated using a base of $50{ }^{\circ} \mathrm{C}\left(\mathrm{GDD}={ }^{\circ} \mathrm{C}_{\text {daily max }}-{ }^{\circ} \mathrm{C}\right.$ daily $\min / 2)-50)$.

Soil series for plots were obtained from the USDA Natural Resources Conservation Web Soil Survey (http://websoilsurvey.nrcs.usda.gov/app/WebSoilSurvey.aspx). Soil horizon depths were estimated by correlating field data on soil color and related depth with on-line soil series information (https://soilseries.sc.egov.usda.gov/OSD_Docs/). Percent sand, silt, and clay were estimated by matching soil types associated with soil series to the soil triangle. Other soil related data was obtained from the Web Soil Survey (Appendix 3, Table 2).

\section{Correlation}

Parameters were analyzed for correlations with beech scale infestation and Neonectria infection in JMP 12.0® (SAS Institute Inc., Cary, NC) using plot as the sampling unit. Correlation coefficients comparing all possible pairs of parameters were generated. Graphs for visual displays of correlation matrices were generated in the SAS Visual Analytics Hub Data Explorer® (SAS Institute Inc., Cary, NC). Positive correlation indicates one parameter increases 
or decreases as the other does; negative correlation indicates one parameter increases when the other decreases. These data were used only for exploratory analysis in prelude to multivariate analyses.

\section{Principal Component Analysis and General Linearized Model}

Data were evaluated with principal component analysis (PCA) in JMP 12.0 to reduce data set to a few principal components, or latent variables, most responsible for the variance within a data set. Latent variables are composed of the recorded parameters. Loading values for recorded parameters generated by PCA range from -1 to 1 and indicate the amount of variation in each parameter explained by the latent variable. Absolute values farther from zero suggest more variation is explained. The loading values table in a JMP 12.0 PCA output assigns transparencies to each value, with less transparency indicating a greater distance from zero relative to other values. In the PCA output from the data for this study transparencies shifted with absolute loading values $\geq 0.4000$. The goal of PCA was to reduce a large number of parameters to a few important latent variables. Given the close relationship between scale infestation and Neonectria infection the inclusion of either could disrupt the calculation of loading values for parameters composing latent variables. To avoid such disruption scale infestation and infection were excluded in PCA but used in subsequent regression analyses as independent variables (predictors).

Parameters estimated by PCA to have higher loading values $(\geq 0.4000)$ in significant principal components were selected to generate latent variables used as independent variables in the following stepwise multiple regression model....

$$
\mathrm{y}_{\mathrm{n}}=\beta_{0}+\beta_{1}\left(\mathrm{~b}_{\mathrm{n} 1} \mathrm{x}_{\mathrm{n} 1}+\cdots+\mathrm{b}_{\mathrm{ni}} \mathrm{x}_{\mathrm{ni}}\right)+\beta_{2}\left(\mathrm{~b}_{\mathrm{n} 2} \mathrm{x}_{\mathrm{n} 2}+\cdots+\mathrm{b}_{\mathrm{nj}} \mathrm{x}_{\mathrm{nj}}\right)+\cdots+\beta_{\mathrm{p}}\left(\mathrm{b}_{\mathrm{np}} \mathrm{x}_{\mathrm{np}}+\cdots+\mathrm{b}_{\mathrm{nq}} \mathrm{x}_{\mathrm{nq}}\right)+\varepsilon_{\mathrm{n}}
$$

....where $\mathrm{y}$ is the response variable, $\beta_{0}$ is the $\mathrm{y}$ intercept, $\beta$ is a parameter estimate (for latent variables), terms in parentheses are latent variables used to predict $\mathrm{y}, \mathrm{b}$ is a loading value used as a coefficient for each parameter comprising a latent variable, $\mathrm{x}$ is a parameter used to build a latent variable, and $\varepsilon$ is the error. All possible interactions were included and scale infestation or Neonectria infection were included as responses or predictors where appropriate to build models. Initial regression analyses identified significant factors and interactions and eliminated nonsignificant factors and interactions. Subsequent analyses included significant factors and interactions from initial analyses and ultimately identified those factors and interactions that are significant based on parameter estimates and p-values generated by the model. All parameters used in regression were checked for normal distributions and transformed when necessary to achieve the best possible fit under a normal curve. Data transformations are listed in Appendix 4, Table 1.

\section{Spatial Analysis}

Samples that are geographically close tend to be more similar than those further apart if there is spatial dependence (Isaaks and Srivastava, 1989), such as relationship to distance from an inoculum source. Distribution patterns that are uniform, random, aggregated, or trending can be identified with semivariograms (Park and Tollefson, 2005). Spatial distributions can be evaluated with semivariograms that graph spatial dependence, plotting one half the squared difference of a 
sample pair against the distance between the two samples generating the parameters range, sill, and nugget (Davis 1994). Range is the distance at which two samples are independent, sill is the semivariance at a distance greater than or equal to the range, and nugget is the semivariance at lag distance zero. Semivariogram functions can be defined as:

$$
\gamma(h)=1 / 2 \mathrm{n}(h) \sum\left[\mathrm{Z}\left(\mathrm{x}_{i}\right)-\mathrm{Z}\left(\mathrm{x}_{i+h}\right)\right]^{2}
$$

where $\gamma(h)$ is one half the variance of two sample values at $h$ distance apart; $\mathrm{Z}\left(\mathrm{x}_{\mathrm{i}}\right)$ is the recorded value at sample point $\mathrm{x}_{i} ; \mathrm{Z}\left(\mathrm{x}_{i+h}\right)$ is the recorded value sample point at $\mathrm{x}_{i+h}$; and $\mathrm{n}(h)$ is the total number of sample pairs for a given $h$ (Park et al., 2011).

Semivariograms do not test the significance level of distribution patterns (Davis, 1994). However, results can be used to characterize the effects of parameters identified by PCA and GLM as important in this study and make inferences about the effects of site features. Ratings of infestation and infection and geographic coordinates (decimal degrees) used to map beech trees and severity of causal agents at sites (Appendix 1) were used to examine spatial dependence with semivariograms generated in GS+ version 10 (Gamma Design Software, Plainwell, MI). Coordinates were converted from decimal degrees to Universal Transverse Mercator (UTM) meters, coordinates for the Holden Arboretum site were not available, and technical problems rendered analysis of data for Beverly I and Blackwater Falls I unsuccessful. Semivariogram models were selected based on best $r^{2}$ for fitting the model. Models that are nugget have random dispersion and no spatial dependence; linear models display and trend but have no spatial dependence. Gaussian, exponential, and spherical models indicating an aggregation or some pattern and spatial dependence are of interest for spatial analysis. The degree of spatial dependence is represented by the percent variability explained by the model, (sill-nugget)/sill x100 (Park et al., 2011).

\section{Results}

\section{Cryptococcus Infestation and Neonectria Infection Ratings}

Mean counts of adults under wax tufts from ten $6.5 \mathrm{~cm}^{2}$ beech bark samples collected for each scale infestation category indicate the qualitative visual ratings are representative of different scale populations (Figure 1). There is an exponential relationship where mean scale populations more than double from one category to the next. One tailed t-tests indicate all categories have statistically different estimated scale populations $(\mathrm{p}<0.001)$. To be clear it should be noted that for any given beech observed not every $6.5 \mathrm{~cm}^{2}$ of bark necessarily has a population of scales representative of the mean in Figure 1. Some bark sections may have no scale at all but, excepting Category 4, there are a maximum number of scales that could be present for each category. Extrapolating to bole (first $2.4 \mathrm{~m} \mathrm{log}$ ) estimates in the field using estimated bark surface area the infestation rating system follows a similar exponential trend (Figure 2). 


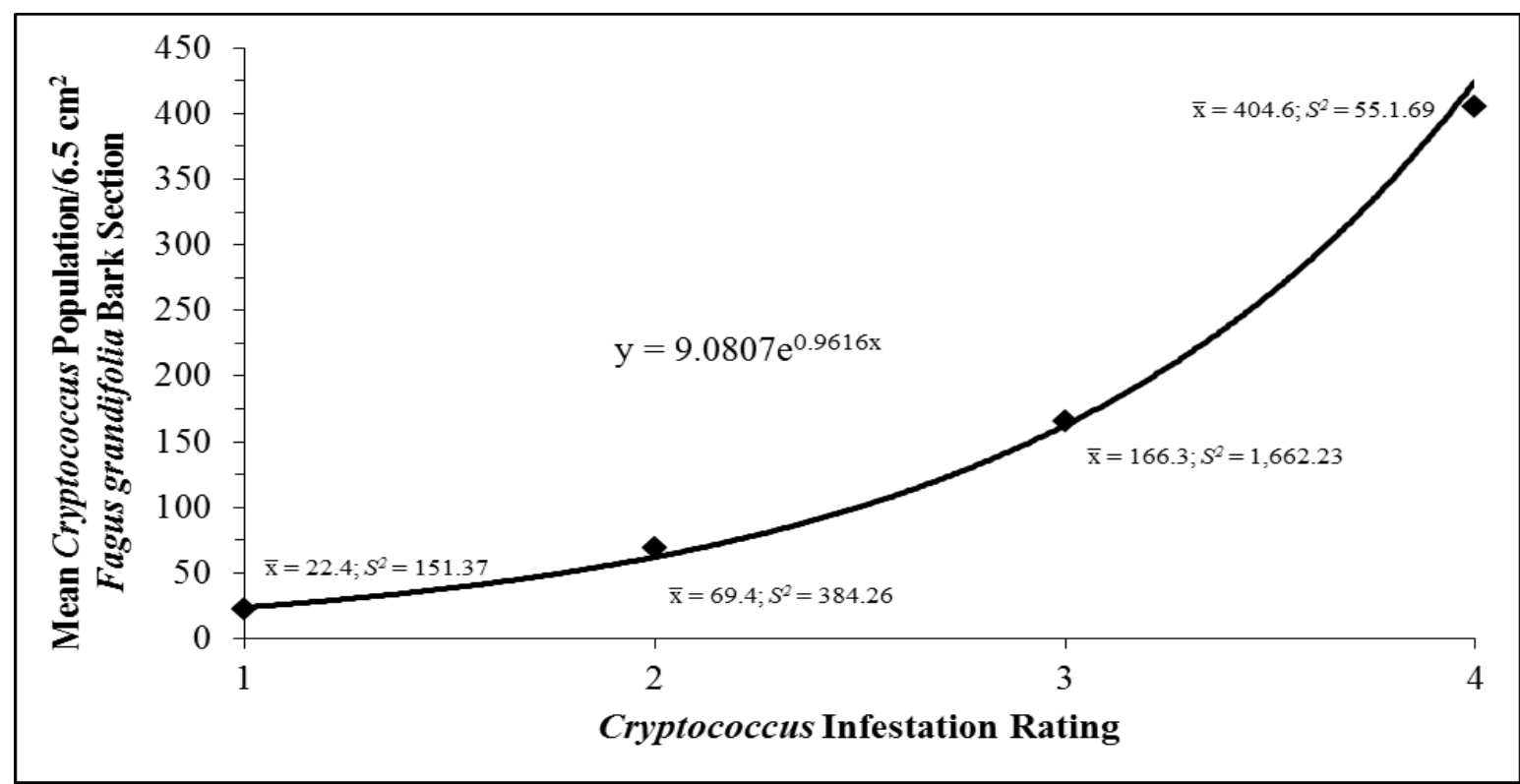

Figure 1: Relationship between Cryptococcus infestation rating and mean number of Cryptococcus adults per $6.5 \mathrm{~cm}^{2}$ Fagus grandifolia bark.

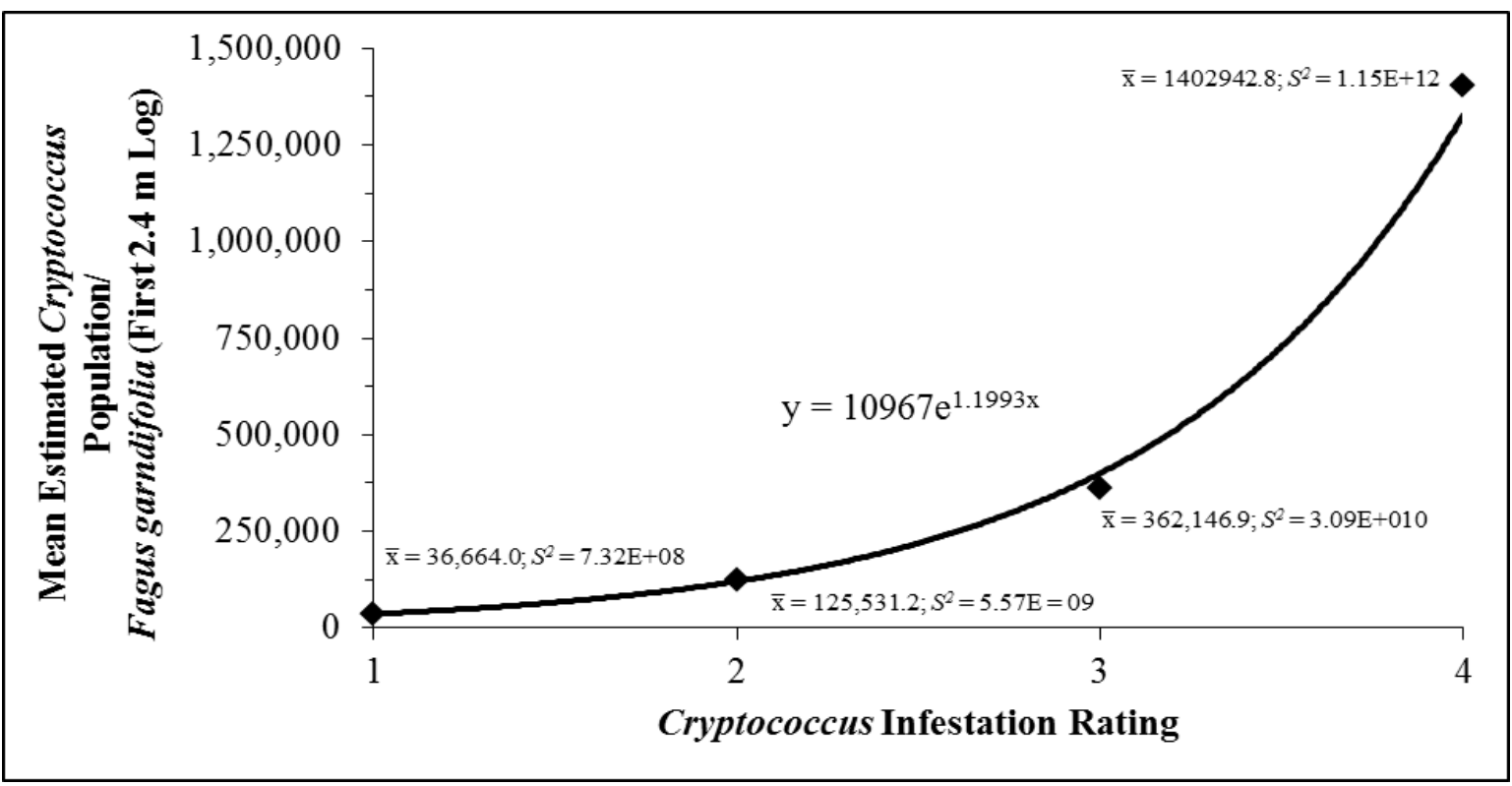

Figure 2: Relationship between Cryptococcus infestation rating and estimated Cryptococcus adult population per Fagus grandifolia calculated from estimated bark surface area.

Mean counts of Neonectria cankers per $0.5 \mathrm{~m}^{2}$ beech bark estimated for each infection category indicate the qualitative visual ratings are representative of different infection levels (Figure 3 ). There is an exponential relationship where cankers at least nearly double from one category to the next. One tailed t-tests indicate all categories have statistically different numbers of cankers $(\mathrm{p}<0.001)$. On any given beech observed not every $0.5 \mathrm{~m}^{2}$ of bark necessarily has cankering representative of the mean in Figure 3. Some bark sections may have no cankers at all but, excepting Category 4 , there are a maximum number of cankers that could be present for each 
category. Extrapolating to bole (first $2.4 \mathrm{~m} \log$ ) estimates in the filed using estimated bark surface area the infection rating system follows a similar exponential trend (Figure 4).

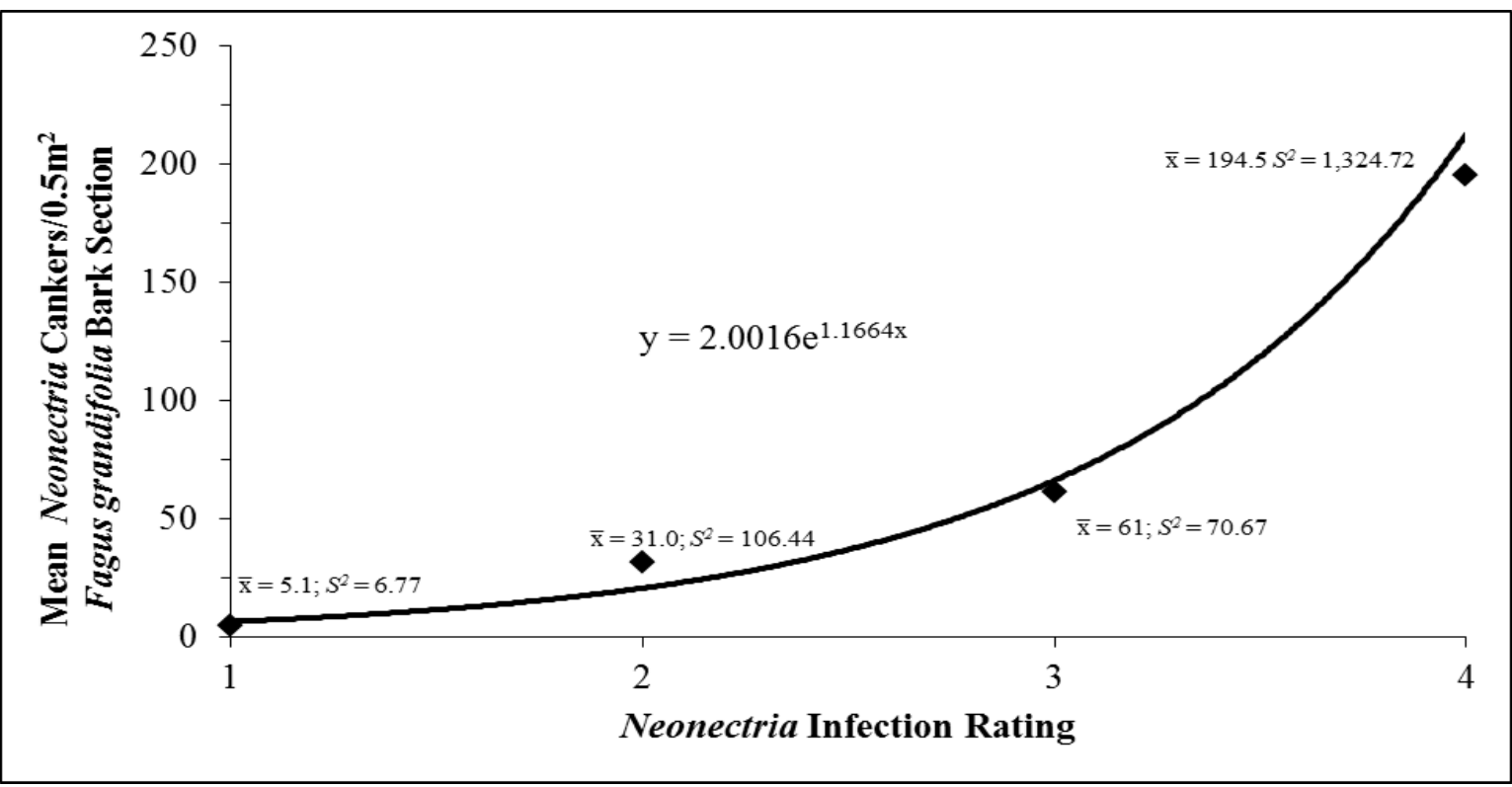

Figure 3: Relationship between Neonectria infection rating and mean number of cankers per $0.5 \mathrm{~m}^{2}$ Fagus grandifolia bark.

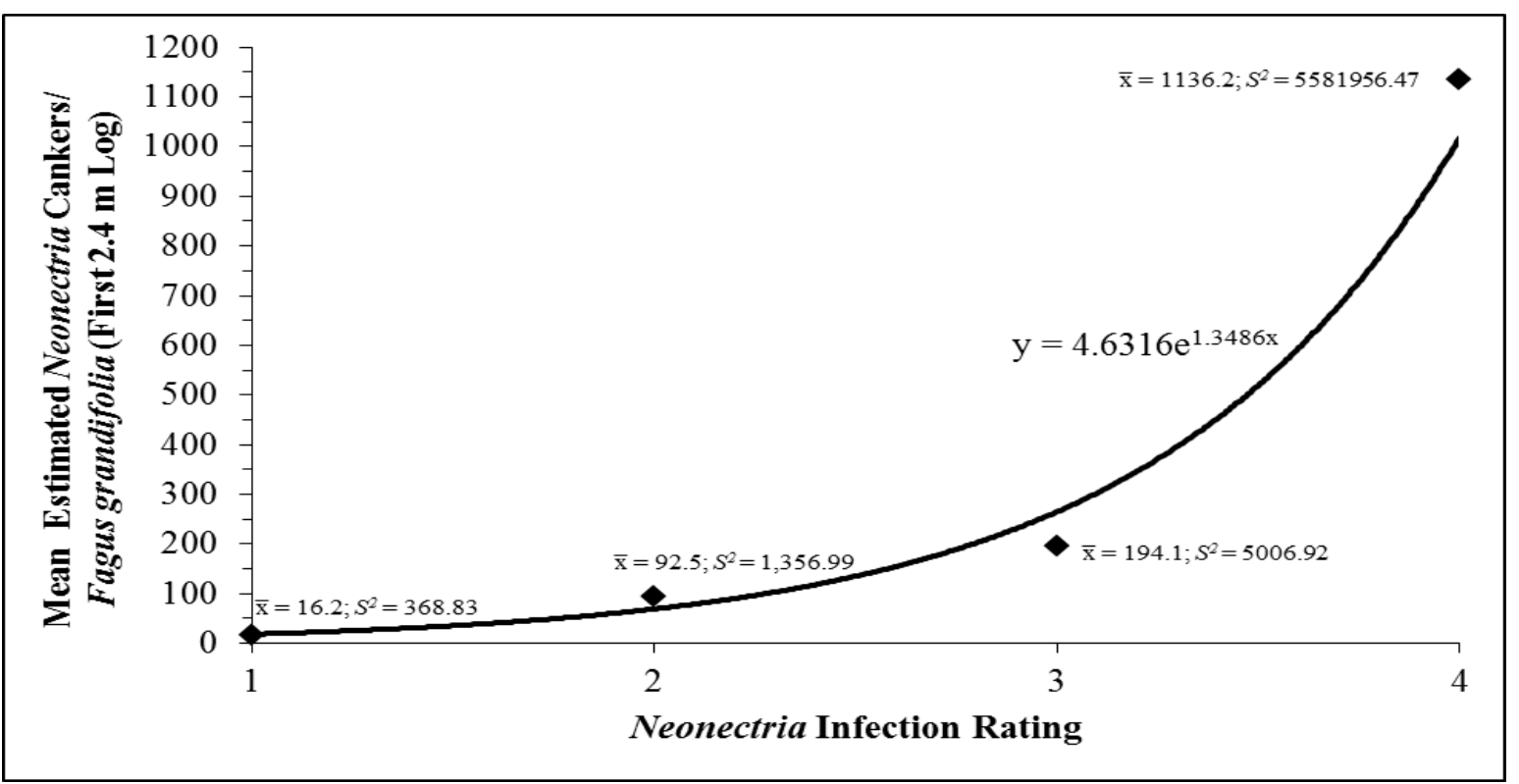

Figure 4: Relationship between Neonectria infection rating and mean number of cankers per Fagus grandifolia calculated from estimated bark surface area.

\section{Cryptococcus Infestation and Neonectria Infection}

Overall, sites had low infestation and infection ratings (Table 4). Most American beech in the study plots had trace $(36.7 \%)$ or light $(31.4 \%)$ beech scale infestations, less than $1 \%$ were heavily infested (Figure 5). An overwhelming majority (69.7\%) of beech had no Neonectria 
infection, but heavy infection (15.1\%) was the second most abundant category (Figure 6). Considering concurrent infestation and infection, $14.3 \%$ of beech stems were free of both scale infestation and Neonectria infection, 28.2\% had trace infestation and no infection, and 24.3\% were lightly infested but not infected (Figure 7).

Table 4: Mean Cryptococcus infestation and Neonectria infection ratings at sites.

\begin{tabular}{lcc}
\hline \multicolumn{1}{c}{ Site } & Mean Cryptococcus rating & Mean Neonectria Rating \\
\hline Allegheny National Forest & 1.42 & 0.13 \\
Beverly, I & 0.20 & 0.20 \\
Beverly, II & 1.00 & 0.46 \\
Blackwater Falls I & 1.19 & 1.37 \\
Blackwater Falls II & 0.15 & 0.36 \\
Blackwater Falls III & 0.04 & 0.49 \\
Cranberry Wilderness & 1.49 & 0.25 \\
Dolly Sods I & 0.84 & 0.42 \\
Dolly Sods II & 1.35 & 0.58 \\
Gaudineer Scenic Area & 1.00 & 0.23 \\
Holden Arboretum & 0.44 & 0.13 \\
Kumbrabow State Forest & 1.33 & 0.40 \\
Middle Mountain & 1.35 & 0.43 \\
Shaver's Fork & 1.14 & 0.00 \\
Great Smoky Mountains & 0.70 & 0.14 \\
\hline
\end{tabular}

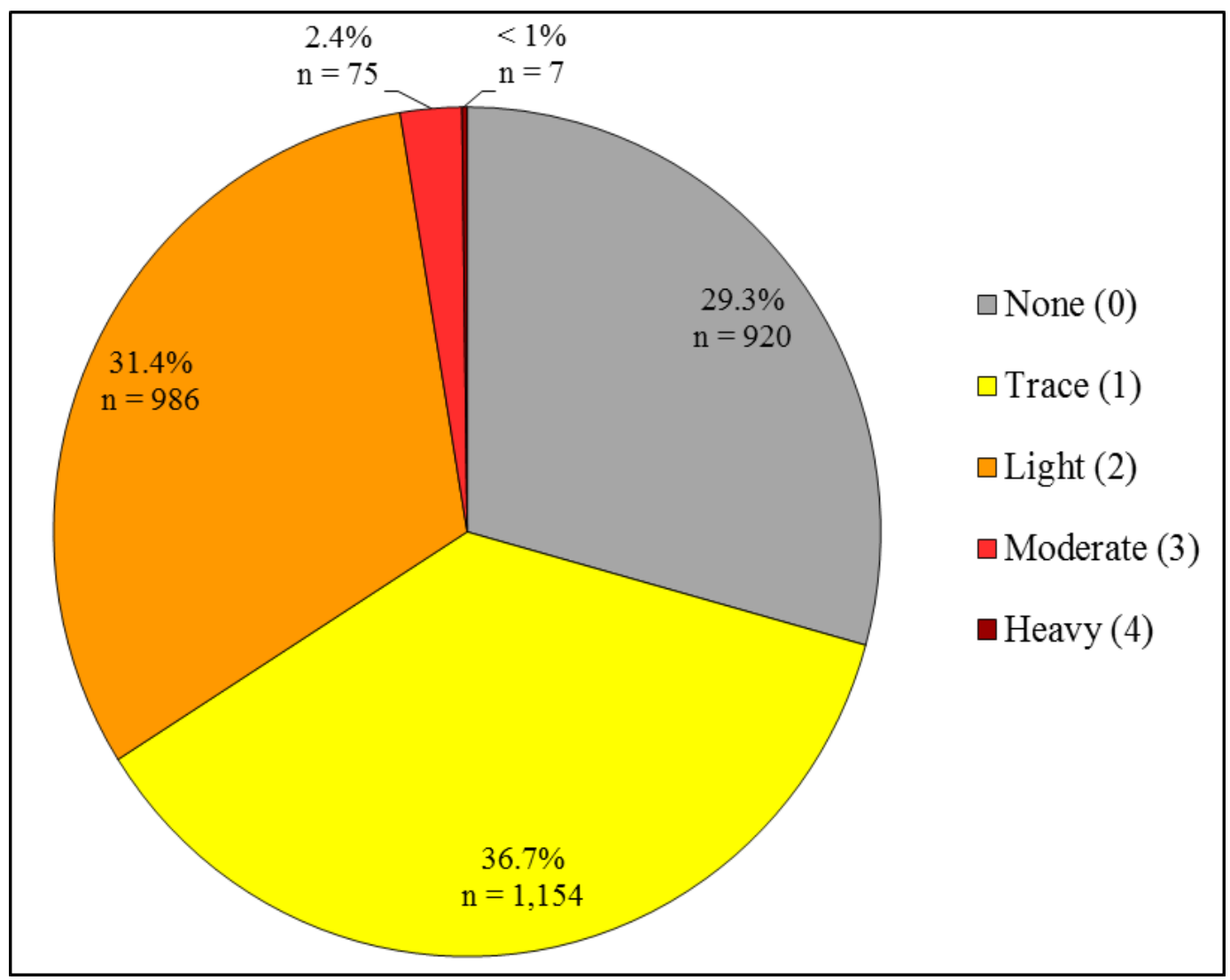

Figure 5: Percent Fagus grandifolia at study sites with Cryptococcus infestation ratings of None (0), Trace (1), Light (2), Moderate (3), and Heavy (4), $\mathrm{N}=3,142$. 


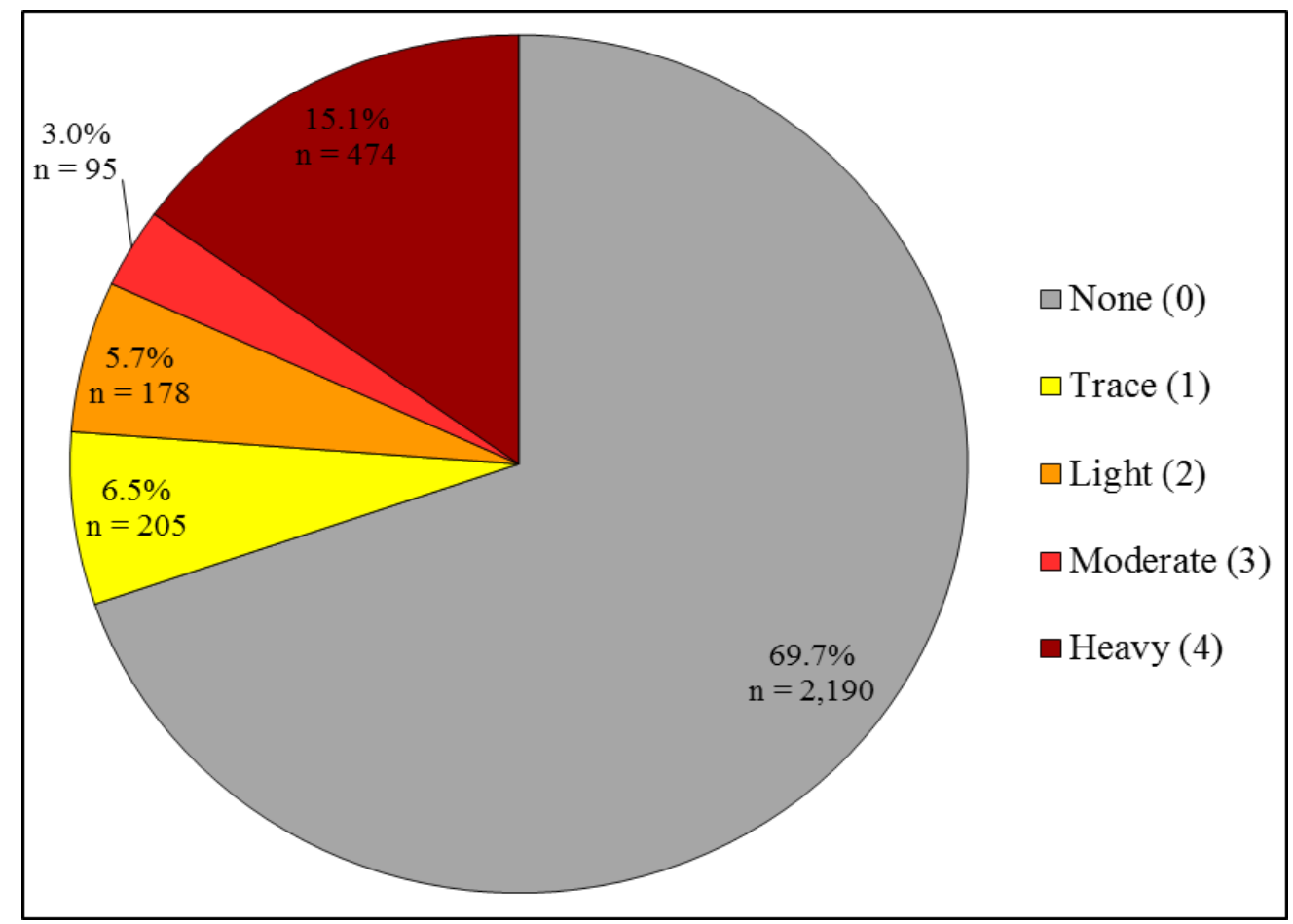

Figure 6: Percent Fagus grandifolia at study sites with Neonectria infection ratings of None (0), Trace (1), Light (2), Moderate (3), and Heavy (4), N = 3,142.

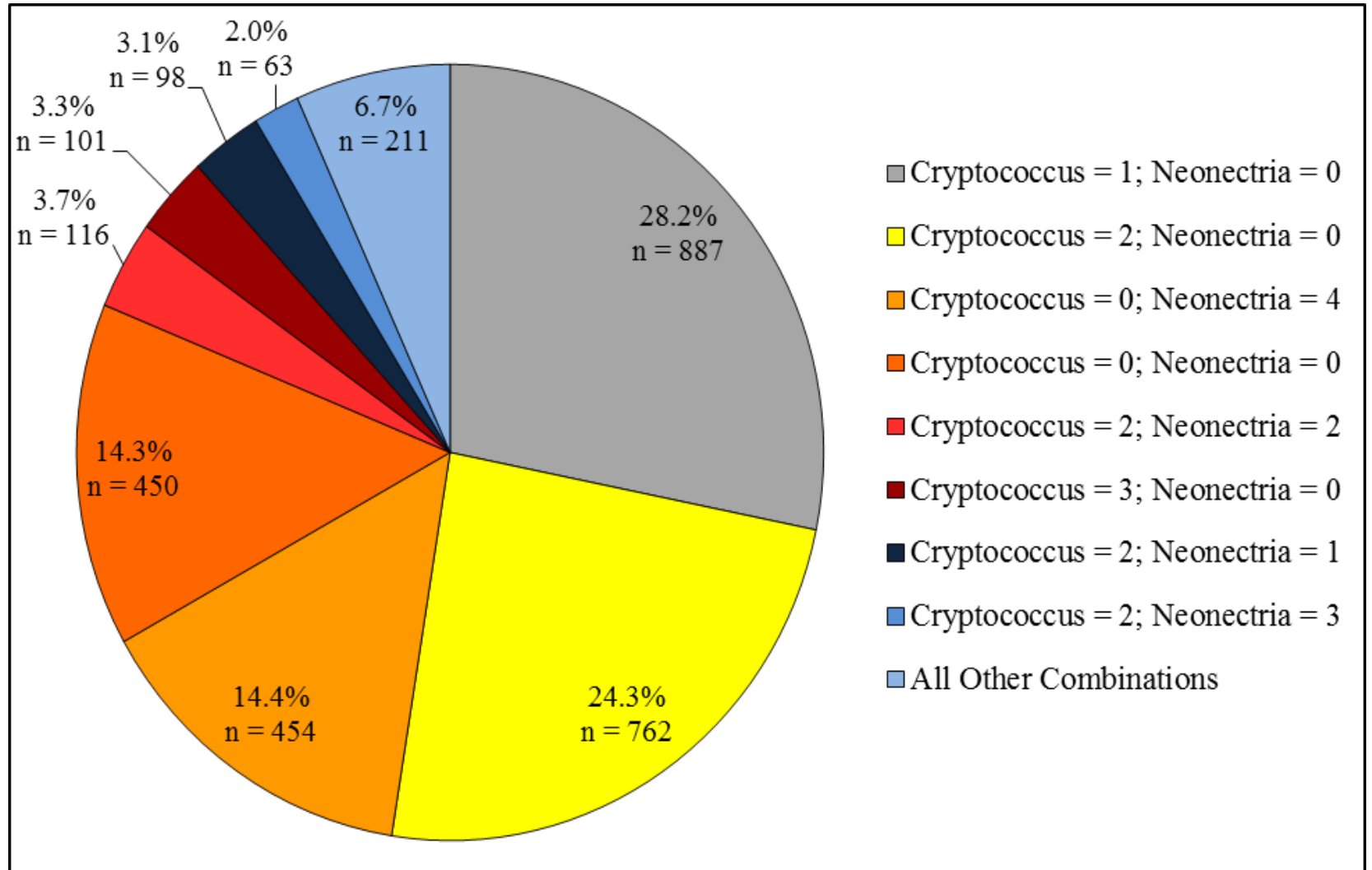

Figure 7: Percent Fagus grandifolia at study sites with concurrent Cryptococcus infestation and Neonectria infection ratings, $\mathrm{N}=3,142$. 
The largest beech diameter classes had the lowest mean infestation ratings, but each larger diameter class had a small sample size relative to smaller diameter classes (Table 5). Beech 10$20 \mathrm{~cm}$ DBH had the highest mean infestation rating, but beech 50-60 $\mathrm{cm}$ also had a relatively high mean rating. The middle diameter classes with trees ranging from 20-50 $\mathrm{cm}$ DBH had relatively high infection ratings (Table 6). The two largest diameter classes had the highest and lowest infection ratings, but each had a small sample sizes relative to smaller diameter classes.

Table 5: Mean Cryptococcus infestation of Fagus grandifolia by diameter class $(\mathrm{N}=3,142)$.

\begin{tabular}{crc}
\hline Diameter Class (cm) & \multicolumn{1}{c}{$\mathbf{n}$} & $\begin{array}{c}\text { Mean Estimated Cryptococcus Rating/ } \\
\text { Fagus grandifolia (First 2.4' Log) }\end{array}$ \\
\hline $0-10$ & 1183 & 1.01 \\
$10.01-20$ & 1179 & 1.32 \\
$20.01-30$ & 522 & 1.16 \\
$30.01-40$ & 171 & 1.12 \\
$40.01-50$ & 55 & 1.13 \\
$50.05-60$ & 18 & 1.25 \\
$60.01-70$ & 8 & 0.75 \\
$70.01-90$ & 6 & 0.59 \\
\hline
\end{tabular}

Table 6: Mean Neonectria infection of Fagus grandifolia by diameter class $(\mathrm{N}=3,142)$.

\begin{tabular}{crc}
\hline Diameter Class (cm) & \multicolumn{1}{c}{ n } & $\begin{array}{c}\text { Mean Estimated Neonectria Rating/ } \\
\text { Fagus } \text { grandifolia (First 2.4' Log) }\end{array}$ \\
\hline $0-10$ & 1183 & 0.48 \\
$10.01-20$ & 1179 & 0.89 \\
$20.01-30$ & 522 & 1.26 \\
$30.01-40$ & 171 & 1.27 \\
$40.01-50$ & 55 & 1.72 \\
$50.05-60$ & 18 & 0.92 \\
$60.01-70$ & 8 & 0.00 \\
$70.01-90$ & 6 & 2.00 \\
\hline
\end{tabular}

All the data regarding infestation and infection indicate plots have low levels of disease and thus well chosen to study of ecological factors limiting disease. Sites also have past mortality. Beech accounted for $57.8 \%$ of standing SCWD, and unknown debris and beech for $23 \%$ of CWD (Figure 8). The next most common debris species was black cherry, accounting for $14.6 \%$ of SCWD and $6.1 \%$ of CWD. 


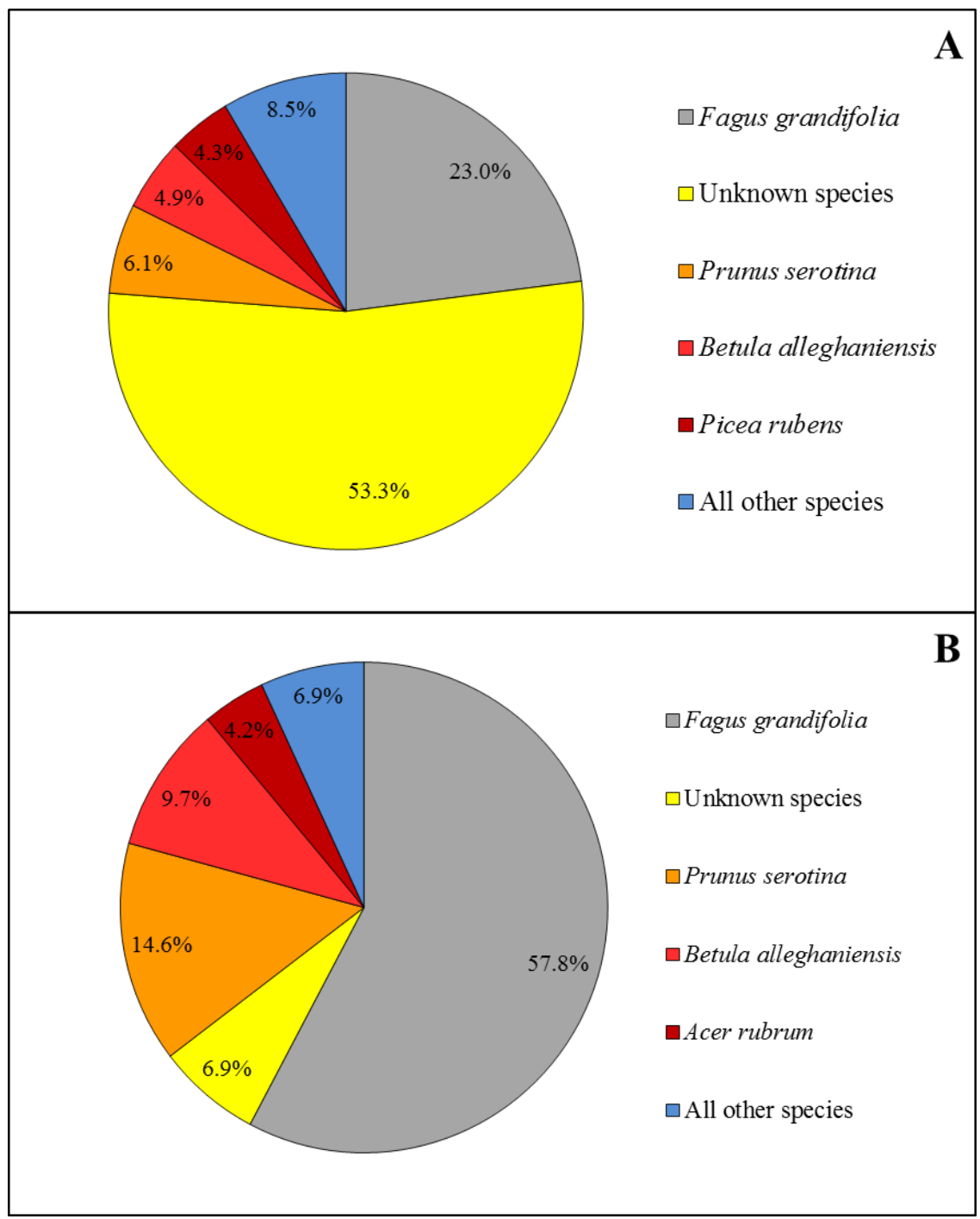

Figure 8: Woody debris, by species, at all 15 study sites. A: Coarse woody debris, percent of volume $\left(\mathrm{m}^{3}\right)$ B: Standing coarse woody debris, percent of volume $\left(\mathrm{m}^{3}\right)$.

Neonectria samples were identified, based on ascospore morphology, as Neonectria faginata (M.L. Lohman, A.M.J. Watson \& Ayers) Castl. \& Rossman. Nucleotide BLASTS with a limited number of fungal isolates in NCBI confirmed morphological identification and that $N$. faginata was isolated regularly from cankers (Appendix 5, Tables 1 and 2). A 506 nucleotide sequence of ITS (88\% of the submitted sequence) from one isolate had $99 \%$ alignment with a known $N$. faginata isolate (Neonectria faginata strain Nf24A1 18S ribosomal RNA gene, partial sequence; internal transcribed spacer $1,5.8 \mathrm{~S}$ ribosomal RNA gene, and internal transcribed spacer 2, complete sequence; and 28S ribosomal RNA gene, partial sequence, Sequence ID: gb|JQ868431.1|Length: 539). A 487 nucleotide ITS1 sequence (96\% of the submitted sequence) from another isolate also had 99\% alignment with a known $N$. faginata isolate (Neonectria faginata strain Nf75A1 18S ribosomal RNA gene, partial sequence; internal transcribed spacer 1, 5.8S ribosomal RNA gene, and internal transcribed spacer 2, complete sequence; and 28S ribosomal RNA gene, partial sequence, Sequence ID: gb|JQ868435.1|Length: 529). Both alignments had E-values of 0.0 suggesting that the probability of alignment due to chance is infinitely small that there is homology between compared sequences. 


\section{Species Composition with Cryptococcus Infestation or Neonectria Infection}

Mean species compositions (\%) were calculated for plots and sites. Sample plots and sites could be described as beech-maple forest type with a small conifer component. Species composition (stems $\geq 10 \mathrm{~cm} \mathrm{DBH)} \mathrm{generally} \mathrm{included} \mathrm{eleven} \mathrm{species} \mathrm{seen} \mathrm{in} \mathrm{Figure} \mathrm{9.} \mathrm{Plots} \mathrm{and} \mathrm{sites}$ inherently contained high proportions of beech from experimental design, maple as a group (red maple, Acer rubra; sugar maple, Acer saccharum, striped maple; Acer pensylvanicum L.) was second in abundance and conifer components consisted of red spruce (Picea rubens) and hemlock (Tsuga canadensis).

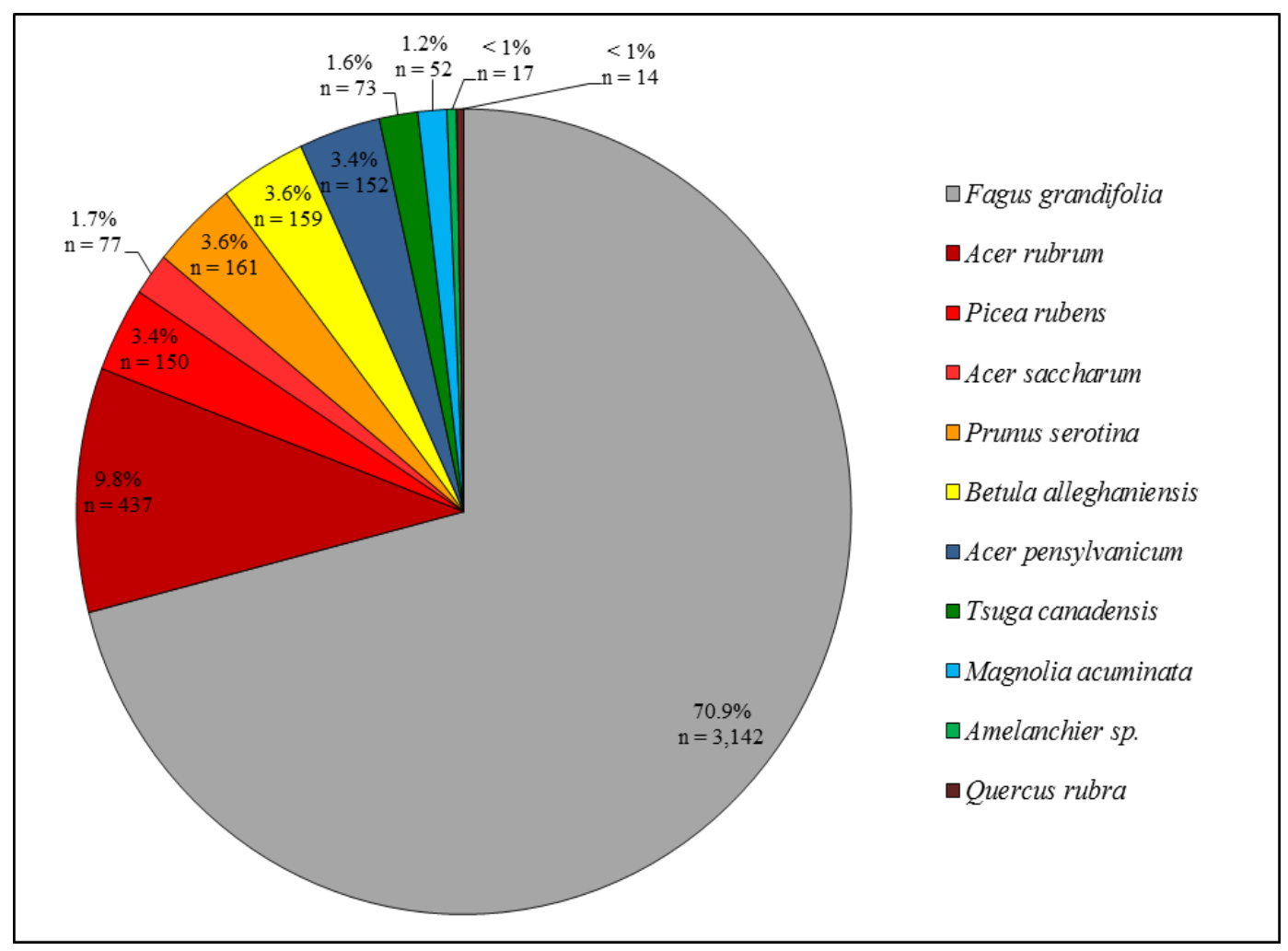

Figure 9: Species compositions of plots $(\mathrm{N}=4,434)$.

\section{Cryptococcus Infestation}

Plots only had trace-to-moderate infestations; $72 \%$ of plots had trace infestation (Figure 10). Mean species compositions (\%) of plots were calculated. Data indicate red spruce and yellow birch components were smaller in light versus trace infestations and absent in moderate infestations. Striped maple proportions were lower in light and moderate infestations but red maple proportions where greater in plots with moderate infestation. Beech proportions remained relatively similar in plots with trace-to-moderate infestation ratings (Figure 11). 


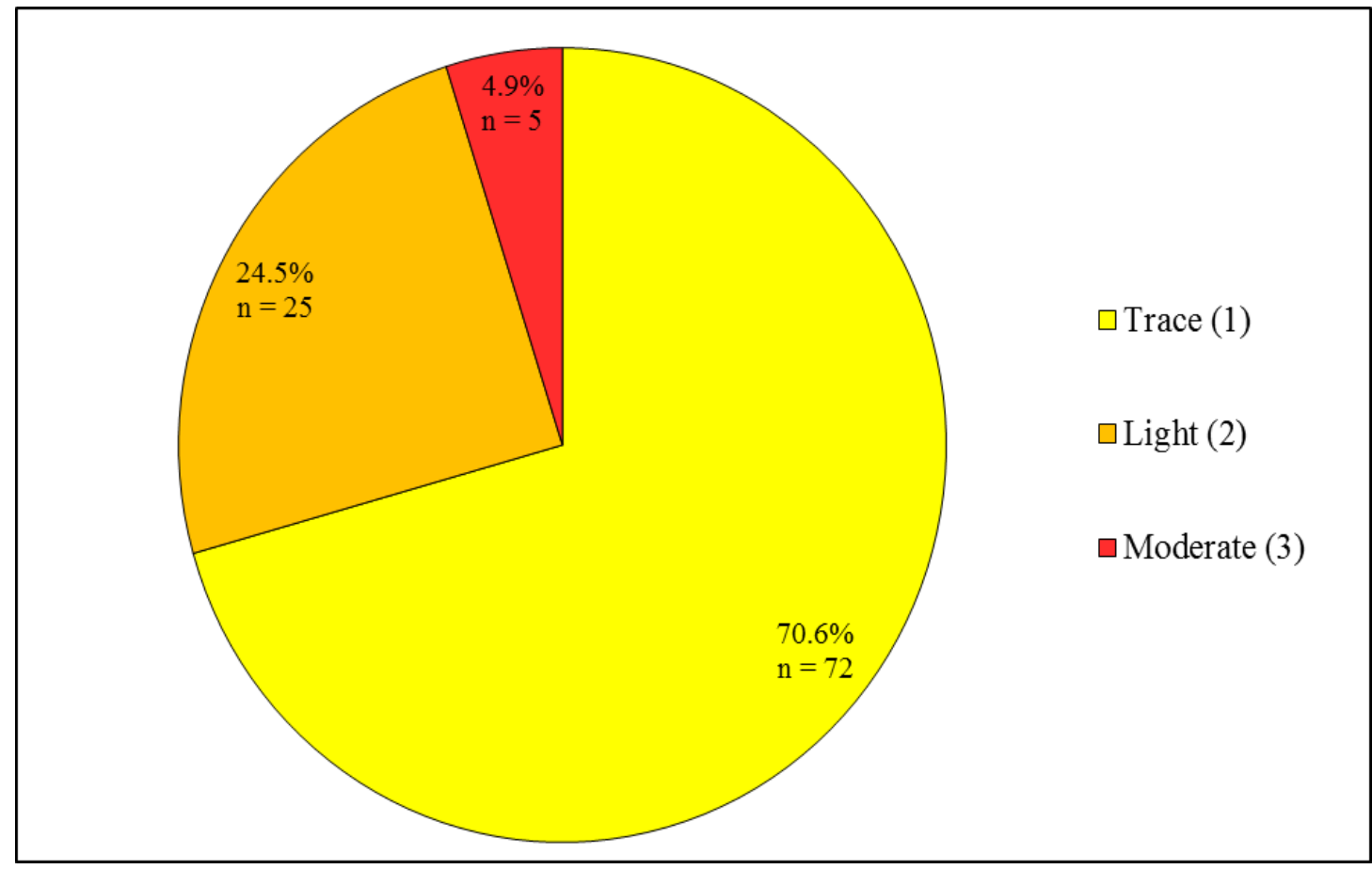

Figure 10: Proportion of plots with trace (1), light (2), and moderate (3) Cryptococcus infestation ratings $(\mathrm{N}=102)$.

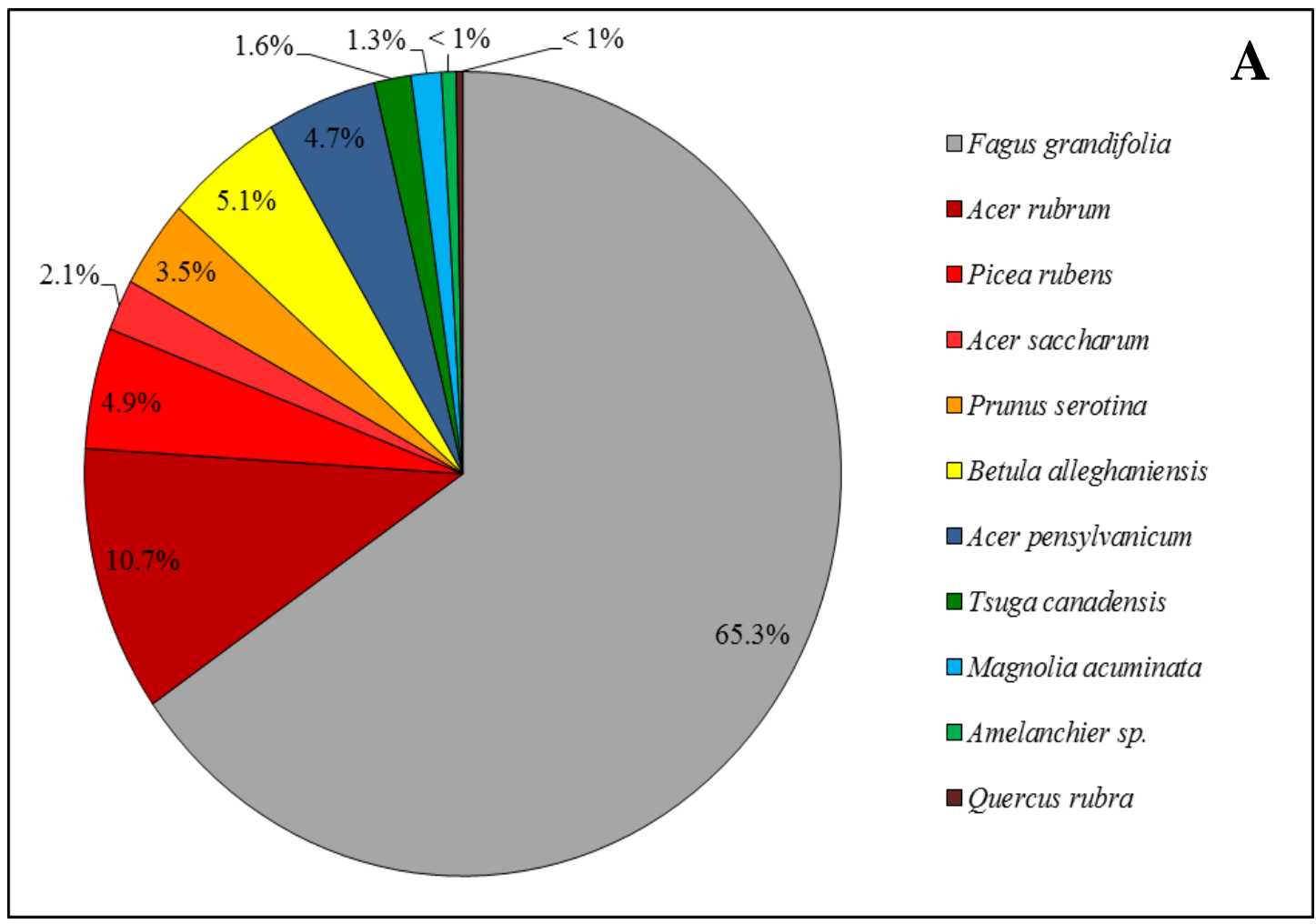



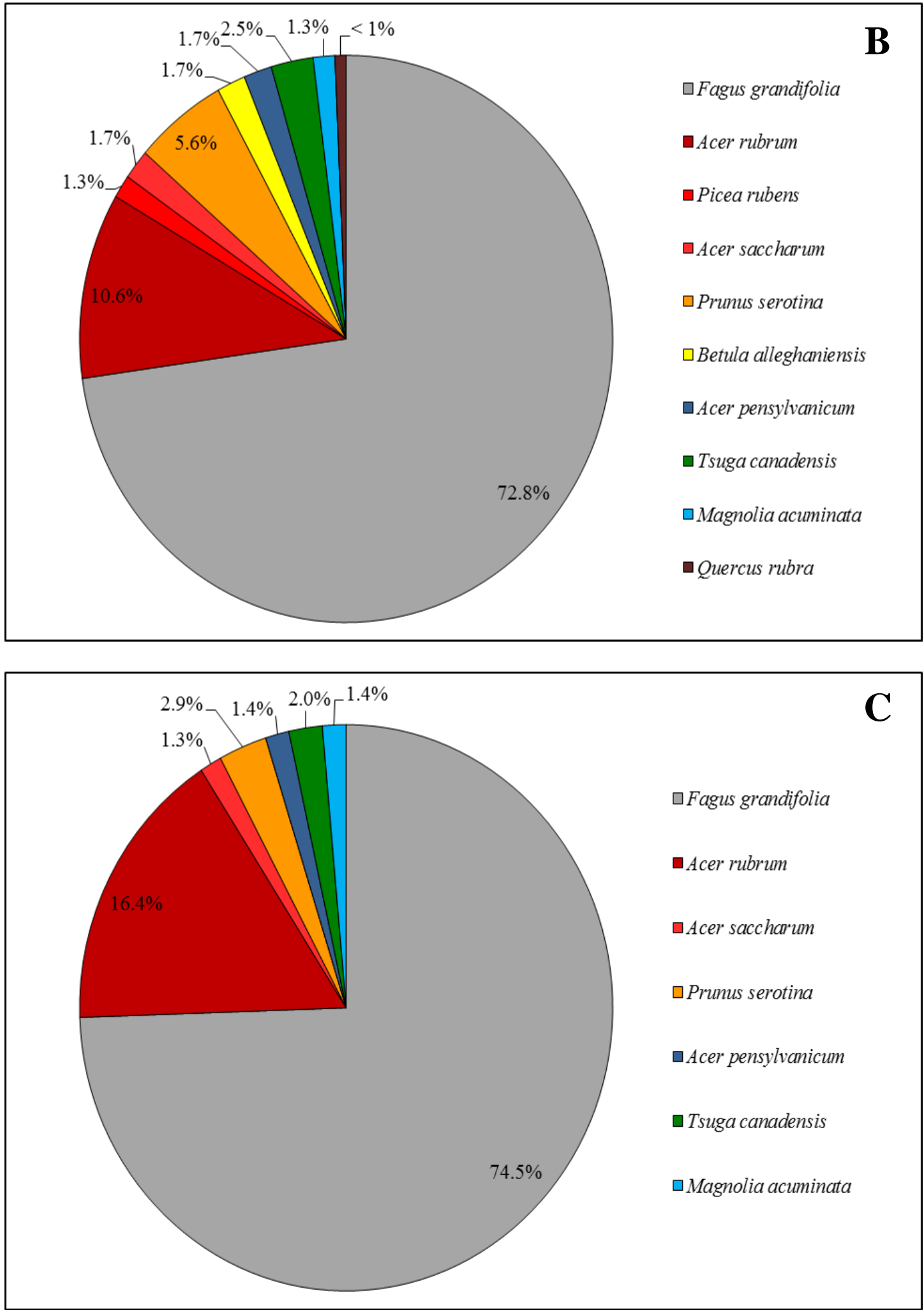

Figure 11: Species compositions of plots with trace $(\mathrm{A}), \mathrm{n}=72$; light $(\mathrm{B}), \mathrm{n}=25$; and moderate (C), $\mathrm{n}=5$ Cryptococcus infestation ratings $(\mathrm{N}=102)$. 


\section{Neonectria Infection}

Trace-to-moderate Neonectria infection was most common in plots and there were equally as many plots $(8.8 \%$ ) with heavy infection as plots without Neonectria (Figure 12). Data indicate red spruce proportions were highest when there was no infection but lowest when infection was trace or light. Striped maple, hemlock, and yellow birch generally were more abundant in plots with higher infection ratings. Beech was more common in plots with trace and light infection ratings (Figure 13).

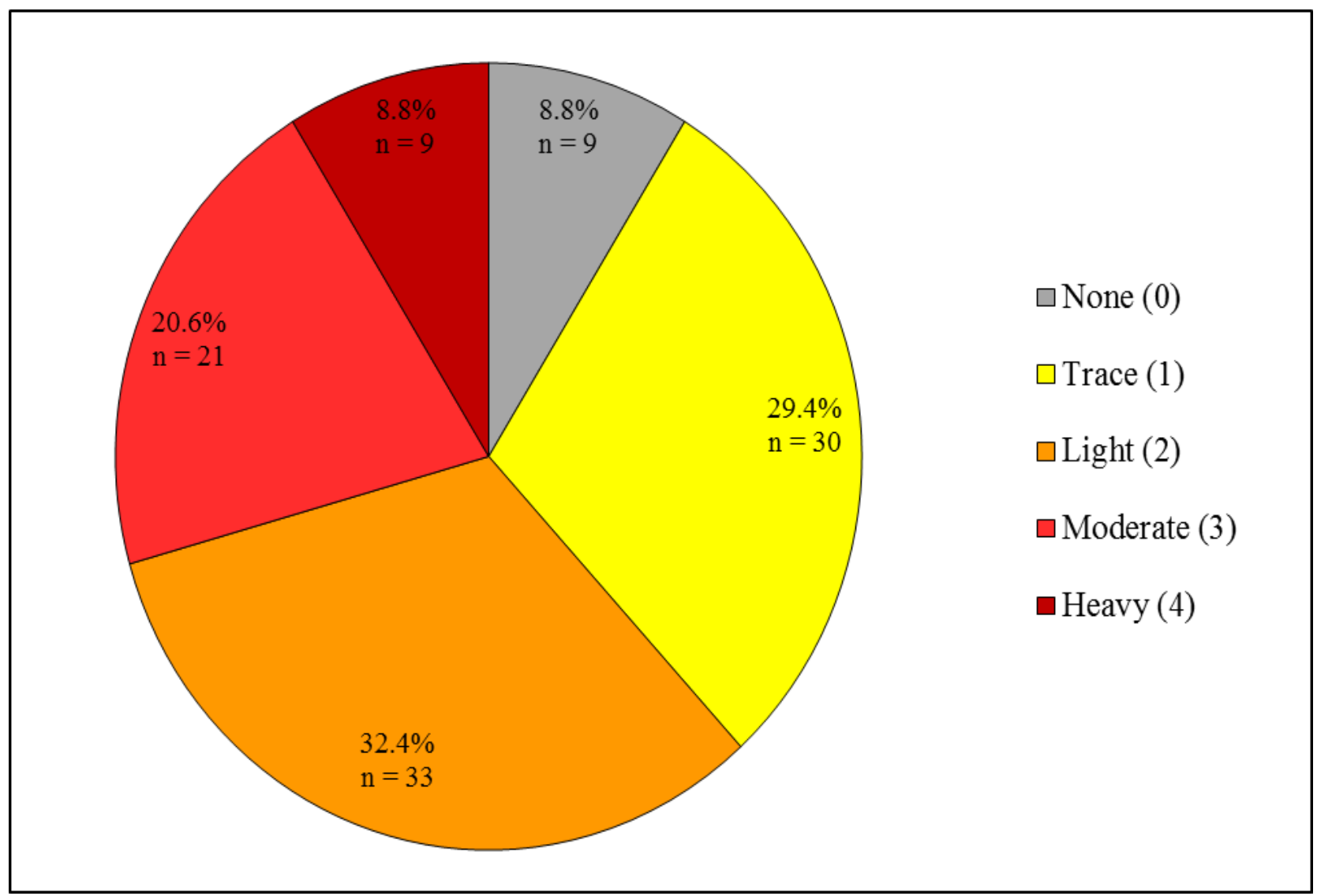

Figure 12: Proportion of plots with none (0), trace (1), light (2), moderate (3), and heavy (4) Neonectria infection ratings $(\mathrm{N}=102)$. 

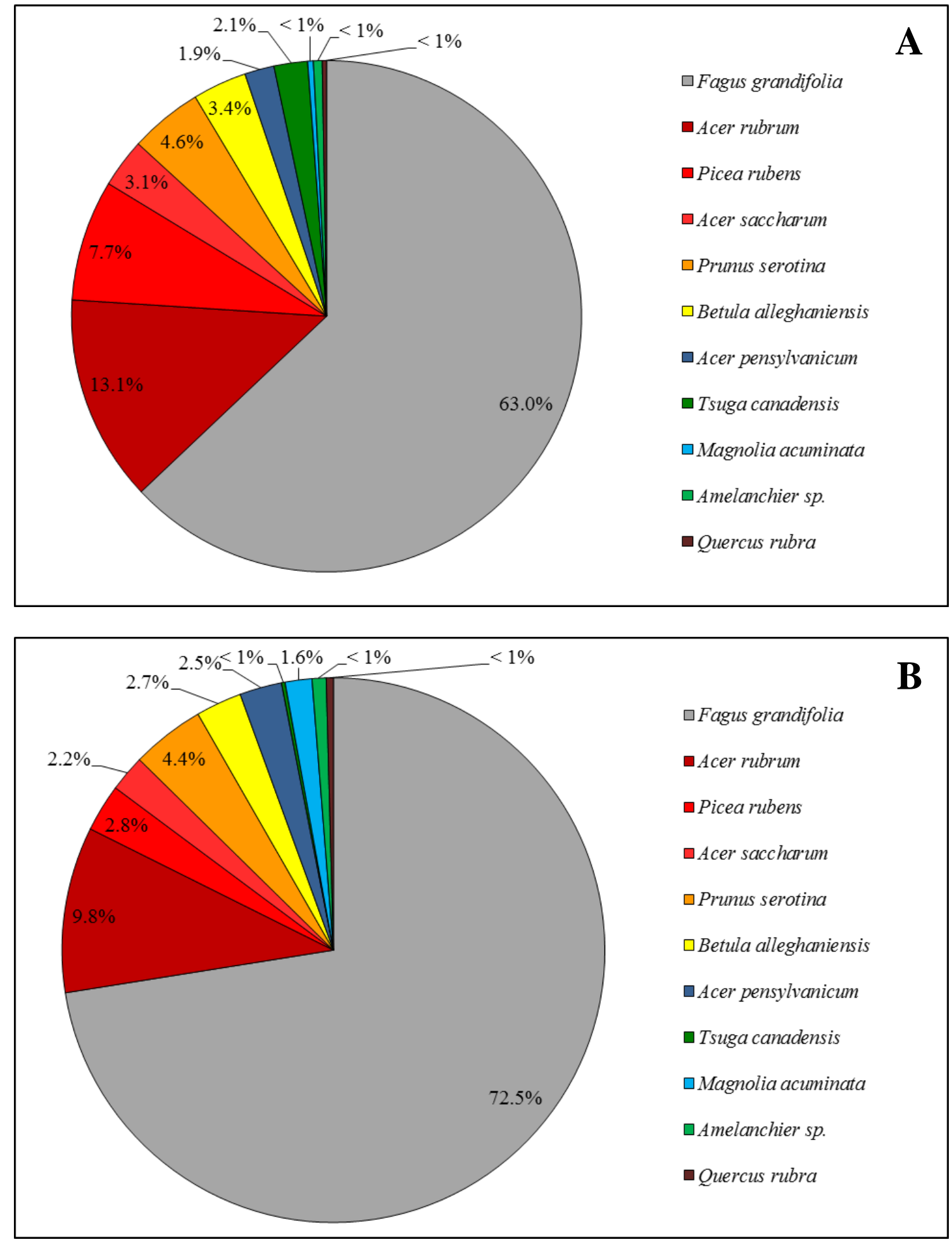

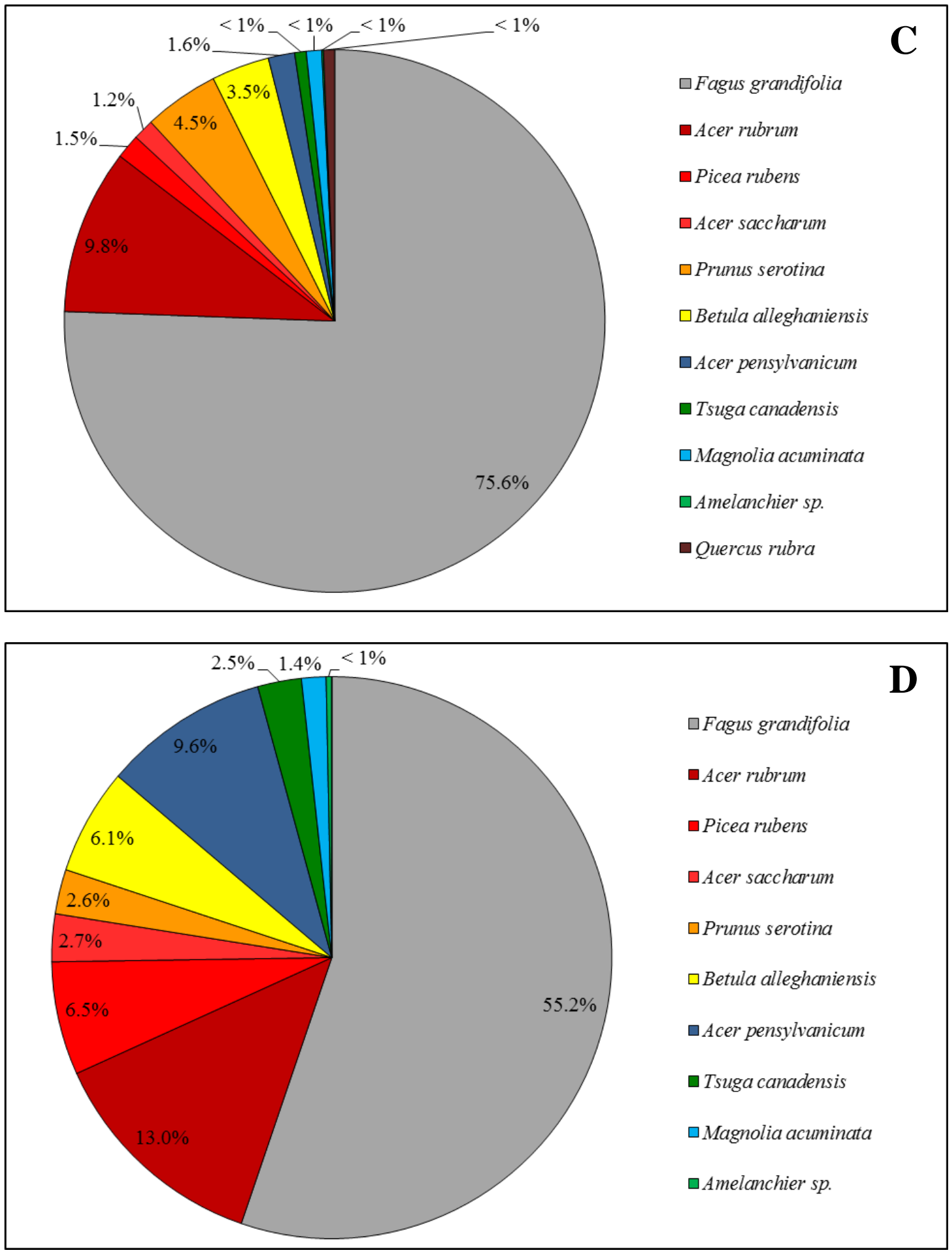


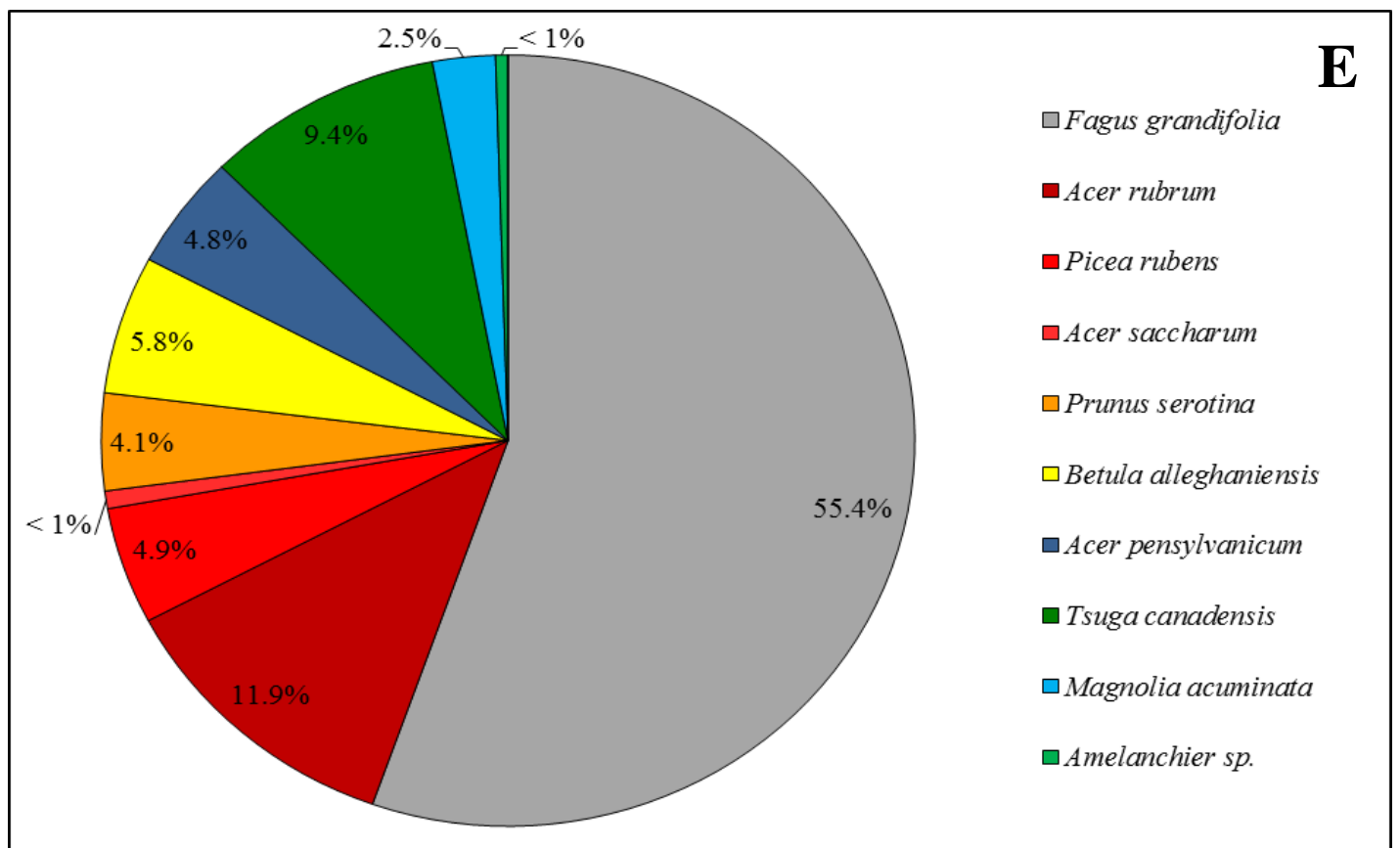

Figure 13: Species compositions of plots with none $(\mathrm{A}), \mathrm{n}=9$; trace $(\mathrm{B}), \mathrm{n}=30$; light $(\mathrm{C}), \mathrm{n}=$ 33; and moderate $(\mathrm{D}), \mathrm{n}=23$; and heavy $(\mathrm{E}), \mathrm{n}=9$ Neonectria infection ratings $(\mathrm{N}=102)$.

\section{$\underline{\text { Analyses of Parameters Representing Ecological Factors }}$}

\section{Correlation}

Exploratory analyses indicate parameters have generally weak-to-moderate correlations with Cryptococcus infestation or Neonectria infection (Appendix 4, Figure 1). Scale infestation and Neonectria infection had weak negative correlation $(r=-0.068)$. The strongest correlation for scale infestation was beech DBH, however it was weak $(r=0.316)$. The strongest correlation for Neonectria infection was striped maple percentage of CWD $(r=0.912)$, the next strongest correlation was soil E horizon thickness $(r=0.293)$. Given this data there are no strong correlations for any parameter with infestation or infection except striped maple percentage of CWD. Parameters selected through PCA for further analyses based on the criterion noted above in Methodology are displayed in Appendix 4, Table 1. Correlations of all parameters with infestation and infection are displayed in Appendix 4, Tables 1 and 2.

\section{Principal Component Analyses}

A scree plot suggests four principal components (PC's) account for most of the variance in scale infestation data (Figure 14). Changes in eigenvalue and explanation of variance sharply decrease after four components as indicated by the plotted line. Principal component 1 composed primarily of climate, soils, and stand structure accounts for $9.39 \%$ of variability in data; PC 2 composed primarily species composition and soil profile data accounts for $6.40 \%$ of variability; PC 3 composed primarily of stand density and structure and wind direction accounts for $5.51 \%$ of variability; and PC 4 composed primarily of bark organisms, temperature, and forest floor components accounts for $4.58 \%$ of variability (Figures 15-20). Values farther away from an axis indicate greater explanation of variability in a parameter by that principal component. 


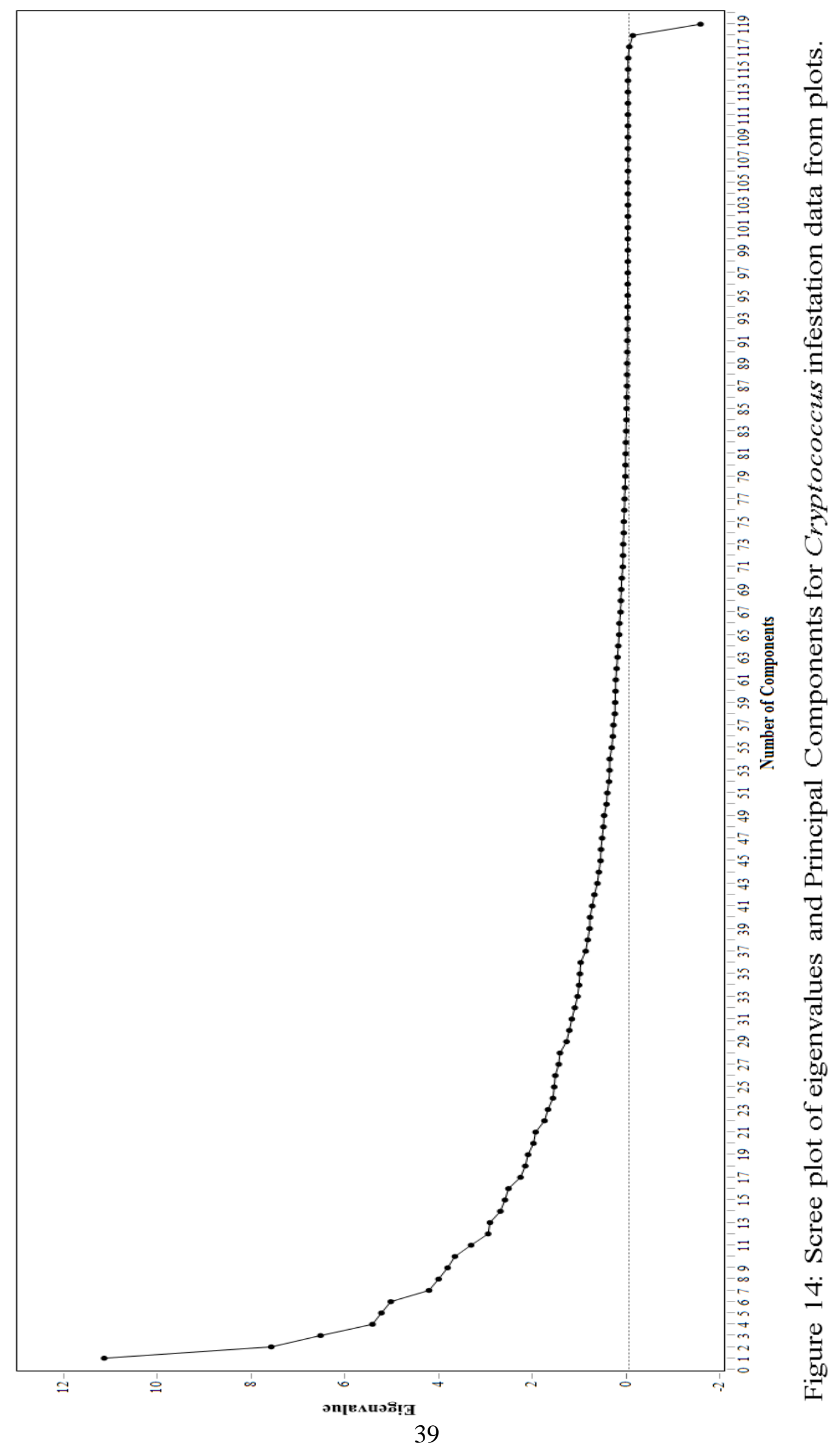




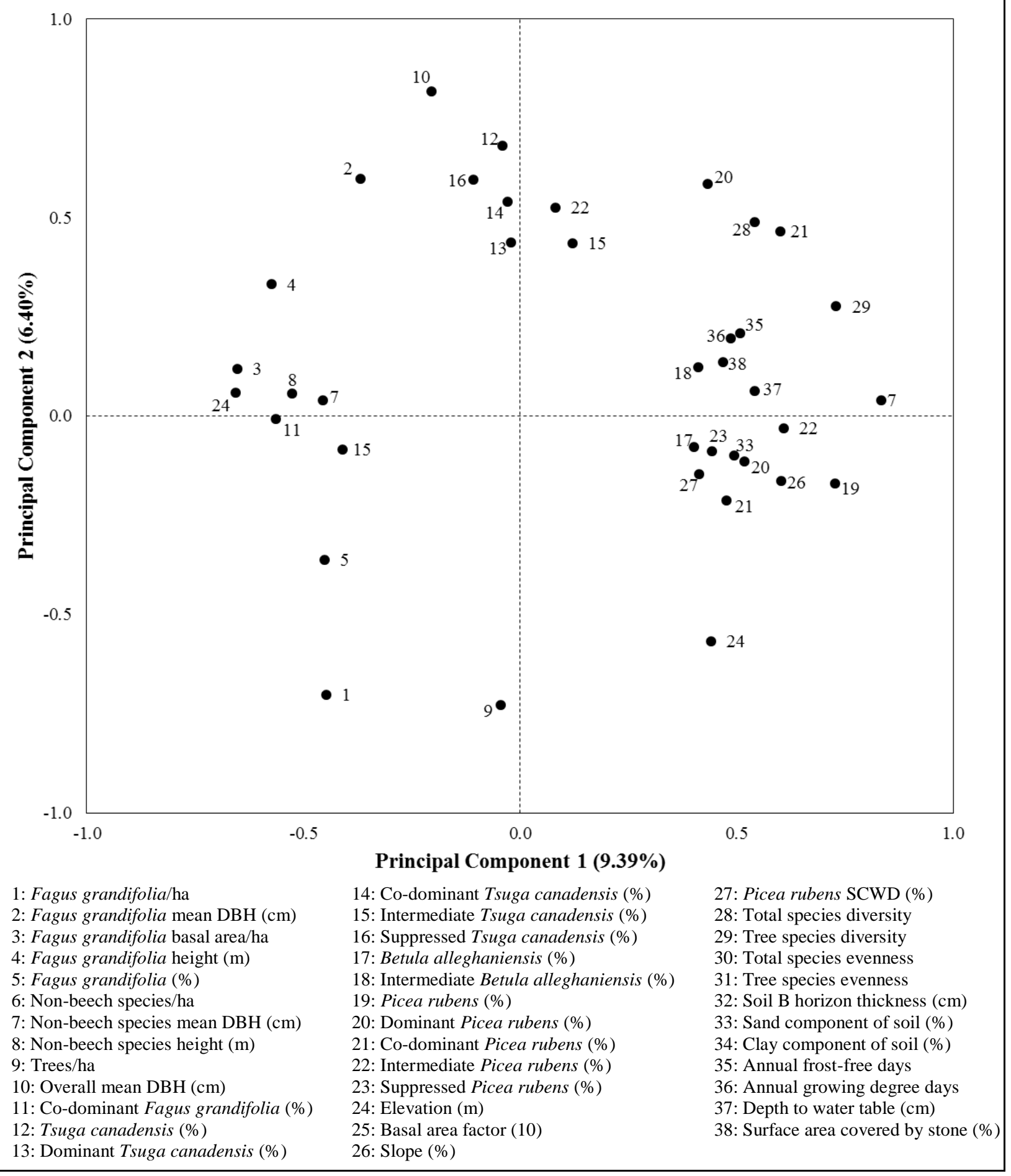

Figure 15: Loading values plot of Principal Components 1 and 2. 


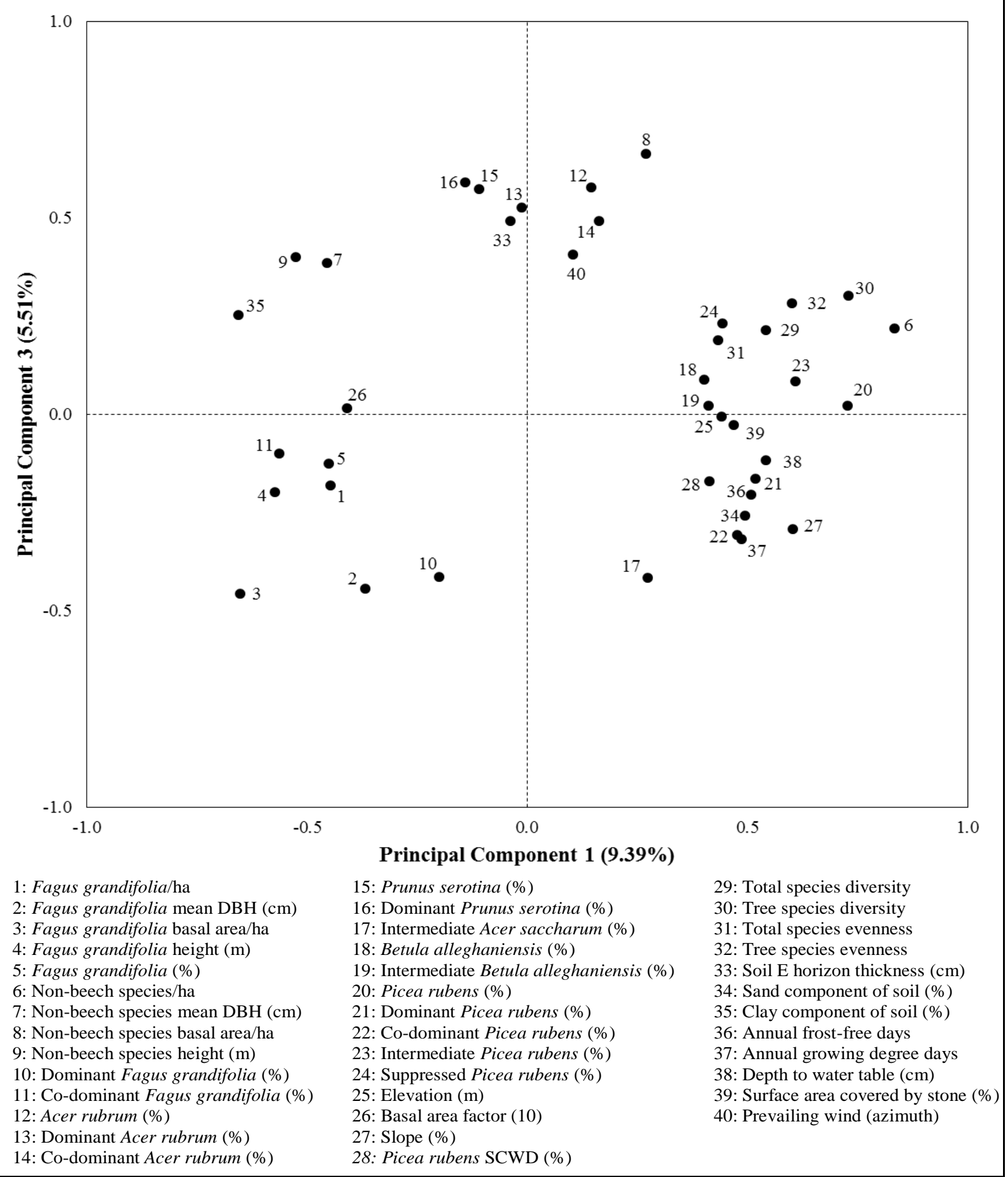

Figure 16: Loading values plot of Principal Components 1 and 3. 


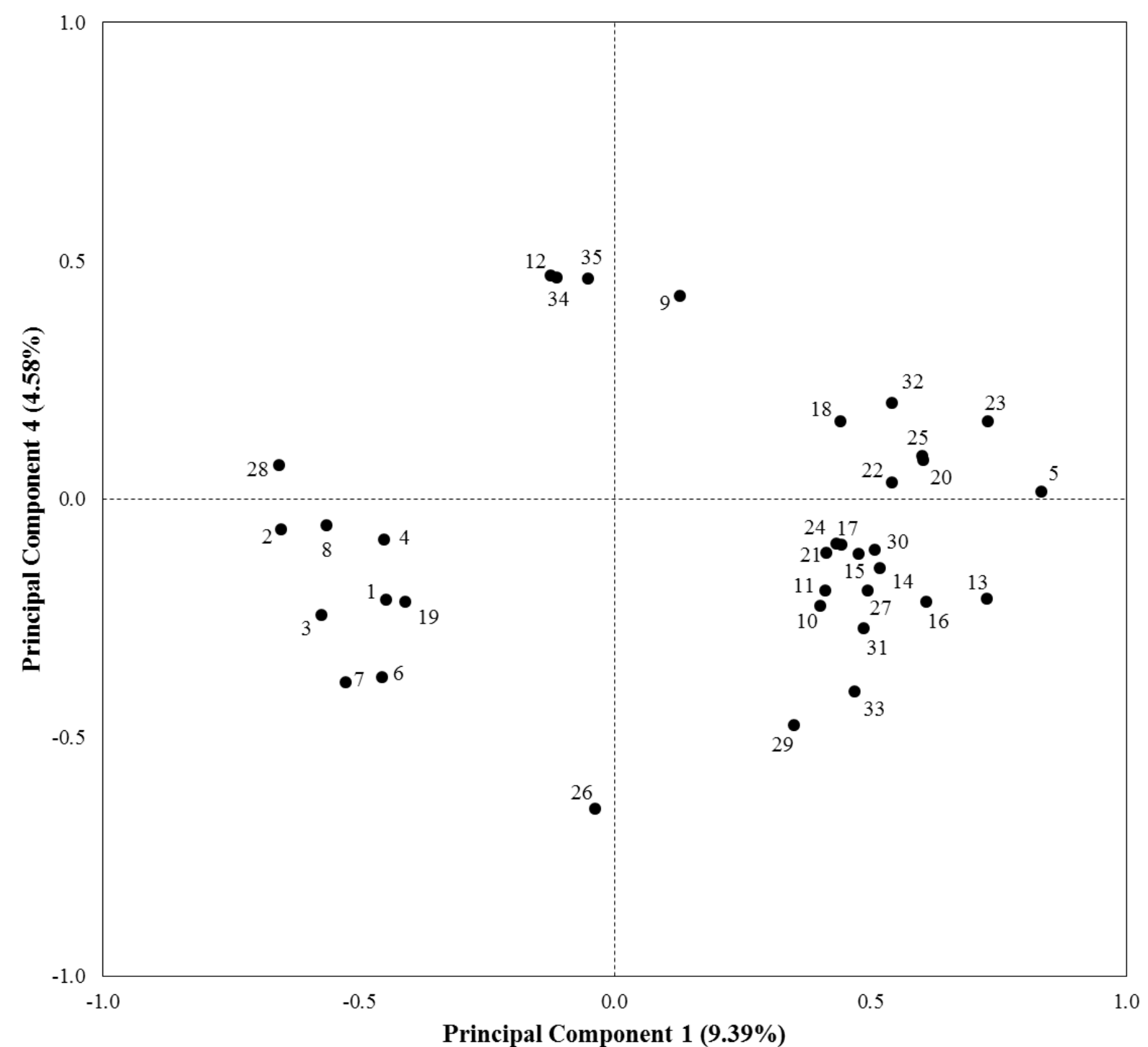

1: Fagus grandifolia/ha

2: Fagus grandifolia basal area/ha

3: Fagus grandifolia height (m)

4: Fagus grandifolia (\%)

5: Non-beech species/ha

6: Non-beech species mean DBH $(\mathrm{cm})$

7: Non-beech species height (m)

8: Co-dominant Fagus grandifolia (\%)

9: Intermediate Acer rubrum (\%)

10: Betula alleghaniensis (\%)

11: Intermediate Betula alleghaniensis (\%)

12: Quercus rubra $(\%)$
13: Picea rubens (\%)

14: Dominant Picea rubens (\%)

15: Co-dominant Picea rubens (\%)

16: Intermediate Picea rubens (\%)

17: Suppressed Picea rubens (\%)

18: Elevation $(\mathrm{m})$

19: Basal area factor (10)

20: Slope $(\%)$

21: Picea rubens SCWD (\%)

22: Total species diversity

23: Tree species diversity

24: Total species evenness
25: Tree species evenness

26: Soil E horizon thickness $(\mathrm{cm})$

27: Sand component of soil (\%)

28: Clay component of soil (\%)

29: Mean annual temperature $\left({ }^{\circ} \mathrm{C}\right)$

30: Annual frost-free days

31: Annual growing degree days

32: Depth to water table $(\mathrm{cm})$

33: Surface area covered by stone (\%)

34: Fagus grandifolia w/ A. rugosa (\%)

35: Fagus grandifolia with blocky cankers (\%)

Figure 17: Loading values plot of Principal Components 1 and 4. 


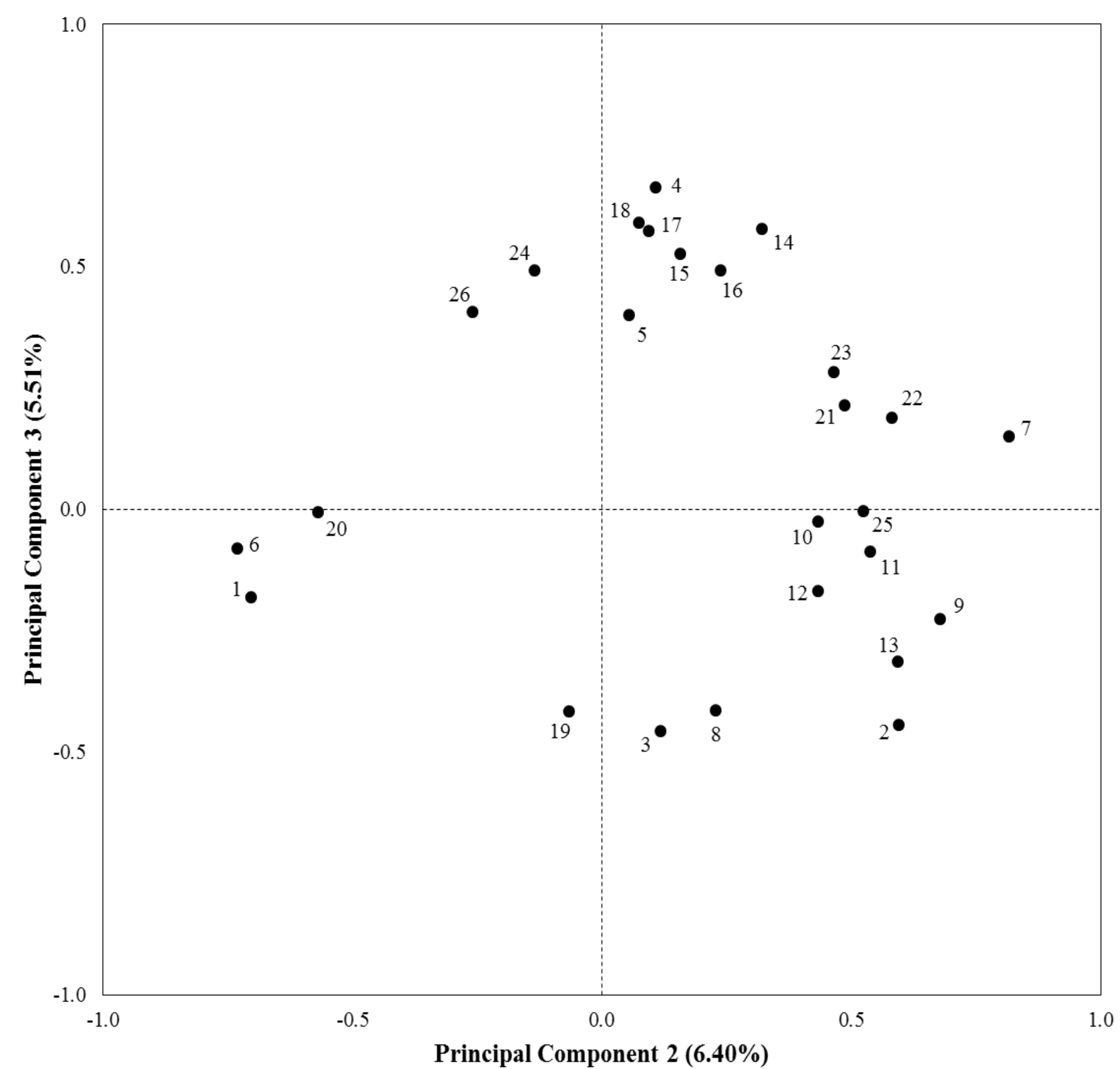

1: Fagus grandifolia/ha

2: Fagus grandifolia mean DBH $(\mathrm{cm})$

3: Fagus grandifolia basal area/ha

4: Non-beech species basal area/ha

5: Non-beech species height $(\mathrm{m})$

6: Trees/ha

7: Overall mean DBH (cm)

8: Dominant Fagus grandifolia (\%)

9: Tsuga canadensis (\%)
10: Dominant Tsuga canadensis (\%)

11: Co-dominant Tsuga canadensis (\%)

12: Intermediate Tsuga canadensis (\%)

13: Suppressed Tsuga canadensis (\%)

14: Acer rubrum (\%)

15: Dominant Acer rubrum (\%)

16: Co-dominant Acer rubrum (\%)

17: Prunus serotina (\%)

18: Dominant Prunus serotina (\%)
19: Intermediate Acer saccharum (\%) 20: Elevation (m)

21: Total species diversity

22: Total species evenness

23: Tree species evenness

24: Soil E horizon thickness $(\mathrm{cm})$

25: Soil B horizon thickness $(\mathrm{cm})$

26: Prevailing wind (azimuth)

Figure18: Loading values plot of Principal Components 2 and 3. 


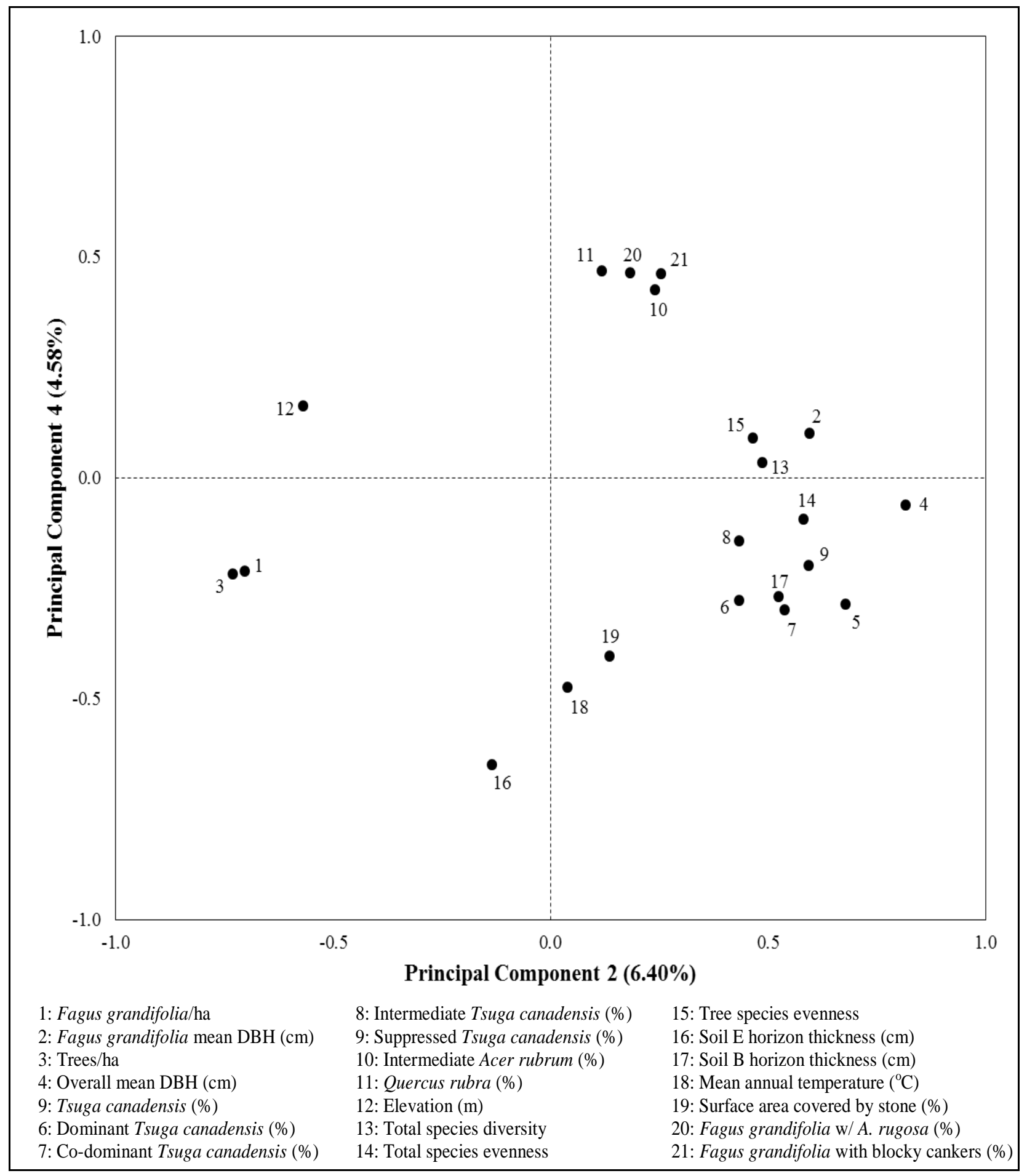

Figure 19: Loading values plot of Principal Components 2 and 4. 


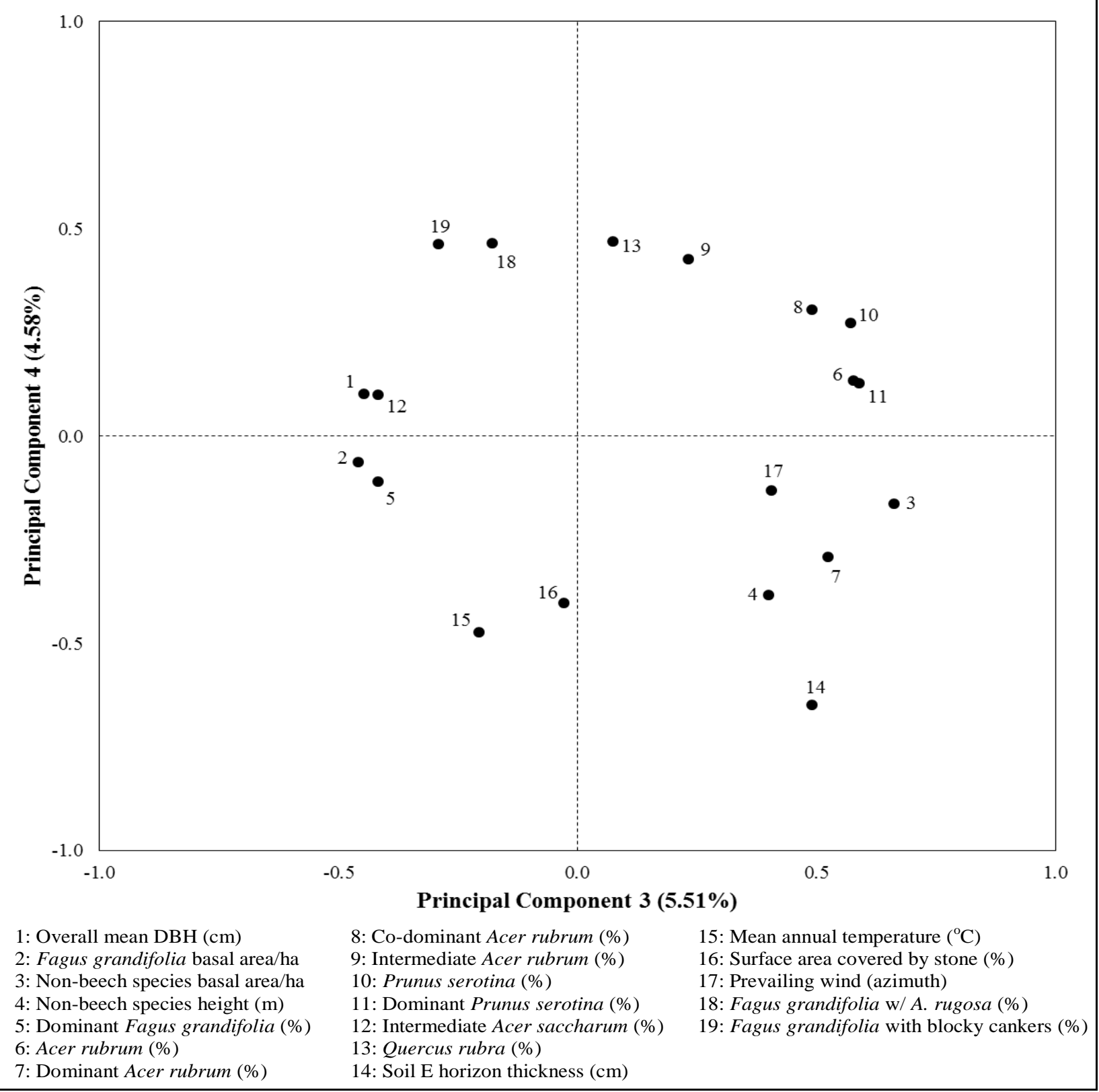

Figure 20: Loading values plot of Principal Components 3 and 4.

\section{Stepwise Multiple Regression Analyses}

Principal component analysis indicates the variability of twenty-nine parameters are well explained by climate, soils and stand structure (PC1); the variability of fourteen parameters are well explained by species composition and soil profile (PC2); the variability of thirteen parameters are well explained by stand density and structure, and wind patterns (PC3); and the variability of seven parameters are well explained by bark organisms, climate, and forest floor (PC4) These results indicate infestation and infection may be affected by density, size, and height of both beech and non-beech species; overall stand density and DBH; species compositions of canopy strata; species diversity; bark organisms; and site related factors such as elevation, slope, wind patterns and soils and the associated availability of water (Table 7). 
Table 7: Loading values (absolute values) of parameters composing Principal Components (PC1-PC4)/Latent Variables used as predictors for Cryptococcus infestation and Neonectria infection in stepwise multiple regressions. Absolute loading values indicate amount of variation in a parameter is explained by the Principal Component/Latent Variable; values $\geq 0.400$ (bold) are considered important (see Methodology section on Page 24 or JMP 12.0 instructions).

\begin{tabular}{|c|c|c|c|c|}
\hline Parameter & $\begin{array}{c}\text { PC1/ } \\
\text { Climate, Soils, } \\
\text { Stand Structure }\end{array}$ & $\begin{array}{l}\text { PC2/ Species } \\
\text { Composition, } \\
\text { Soil Profile }\end{array}$ & $\begin{array}{c}\text { PC3/ Stand } \\
\text { Density } \\
\text { and Structure, } \\
\text { Wind Patterns }\end{array}$ & $\begin{array}{c}\text { PC4/Bark } \\
\text { Organisms, } \\
\text { Climate, } \\
\text { Forest Floor }\end{array}$ \\
\hline Fagus grandifolia/ha & 0.447 & 0.703 & 0.181 & 0.212 \\
\hline Fagus grandifolia mean DBH $(\mathrm{cm})$ & 0.367 & 0.596 & 0.446 & 0.101 \\
\hline Fagus grandifolia basal area/ha & 0.650 & 0.118 & 0.457 & 0.065 \\
\hline Fagus grandifolia height (m) & 0.572 & 0.331 & 0.198 & 0.243 \\
\hline Fagus grandifolia $(\%)$ & 0.450 & 0.363 & 0.126 & 0.085 \\
\hline Non-beech species/ha & 0.835 & 0.040 & 0.218 & 0.014 \\
\hline Non-beech species mean DBH $(\mathrm{cm})$ & 0.454 & 0.040 & 0.384 & 0.374 \\
\hline Non-beech species basal area/ha & 0.271 & 0.109 & 0.663 & 0.166 \\
\hline Non-beech species height (m) & 0.524 & 0.056 & 0.401 & 0.385 \\
\hline Trees/ha & 0.044 & 0.730 & 0.081 & 0.218 \\
\hline Overall mean DBH (cm) & 0.203 & 0.818 & 0.149 & 0.063 \\
\hline Dominant Fagus grandifolia $(\%)$ & 0.200 & 0.229 & 0.415 & 0.110 \\
\hline Co-dominant Fagus grandifolia $(\%)$ & 0.562 & 0.009 & 0.100 & 0.056 \\
\hline Tsuga canadensis $(\%)$ & 0.039 & 0.680 & 0.226 & 0.287 \\
\hline Dominant Tsuga canadensis (\%) & 0.020 & 0.435 & 0.026 & 0.278 \\
\hline Co-dominant Tsuga canadensis (\%) & 0.027 & 0.539 & 0.089 & 0.299 \\
\hline Intermediate Tsuga canadensis (\%) & 0.123 & 0.435 & 0.168 & 0.144 \\
\hline Suppressed Tsuga canadensis (\%) & 0.106 & 0.594 & 0.315 & 0.199 \\
\hline Acer rubrum (\%) & 0.146 & 0.321 & 0.578 & 0.133 \\
\hline Dominant Acer rubrum (\%) & 0.012 & 0.158 & 0.525 & 0.293 \\
\hline Co-dominant Acer rubrum (\%) & 0.163 & 0.239 & 0.491 & 0.303 \\
\hline Intermediate Acer rubrum (\%) & 0.129 & 0.242 & 0.233 & 0.425 \\
\hline Prunus serotina $(\%)$ & 0.108 & 0.095 & 0.573 & 0.271 \\
\hline Dominant Prunus serotina (\%) & 0.140 & 0.075 & 0.590 & 0.127 \\
\hline Intermediate Acer saccharum (\%) & 0.275 & 0.066 & 0.417 & 0.099 \\
\hline Betula alleghaniensis (\%) & 0.403 & 0.079 & 0.087 & 0.223 \\
\hline Intermediate Betula alleghaniensis (\%) & 0.414 & 0.122 & 0.021 & 0.193 \\
\hline Quercus rubra $(\%)$ & 0.124 & 0.119 & 0.075 & 0.469 \\
\hline Picea rubens $(\%)$ & 0.728 & 0.170 & 0.022 & 0.209 \\
\hline Dominant Picea rubens $(\%)$ & 0.520 & 0.116 & 0.164 & 0.145 \\
\hline Co-dominant Picea rubens (\%) & 0.479 & 0.214 & 0.307 & 0.116 \\
\hline Intermediate Picea rubens (\%) & 0.609 & 0.031 & 0.084 & 0.215 \\
\hline Suppressed Picea rubens (\%) & 0.445 & 0.090 & 0.231 & 0.096 \\
\hline Elevation & 0.442 & 0.568 & 0.005 & 0.162 \\
\hline Basal area factor (10) & 0.408 & 0.085 & 0.015 & 0.216 \\
\hline Slope $(\%)$ & 0.604 & 0.164 & 0.293 & 0.081 \\
\hline Picea rubens SCWD (\%) & 0.415 & 0.147 & 0.171 & 0.112 \\
\hline Total species diversity (plots + subplots) & 0.543 & 0.488 & 0.214 & 0.034 \\
\hline Total species evenness (plots + subplots) & 0.435 & 0.583 & 0.188 & 0.094 \\
\hline Tree species diversity (plots) & 0.731 & 0.275 & 0.303 & 0.162 \\
\hline Tree species evenness (plots) & 0.603 & 0.465 & 0.283 & 0.089 \\
\hline Soil E horizon thickness & 0.037 & 0.134 & 0.492 & 0.651 \\
\hline Soil B horizon thickness & 0.084 & 0.525 & 0.004 & 0.270 \\
\hline Mean annual temperature $\left({ }^{\circ} \mathrm{C}\right)$ & 0.351 & 0.039 & 0.206 & 0.474 \\
\hline Annual frost-free days & 0.510 & 0.208 & 0.206 & 0.106 \\
\hline Annual growing degree days & 0.487 & 0.194 & 0.318 & 0.272 \\
\hline Surface area covered by stone $(\%)$ & 0.470 & 0.136 & 0.027 & 0.403 \\
\hline Fagus grandifolia w/ A. rugosa (\%) & 0.112 & 0.183 & 0.177 & 0.465 \\
\hline Fagus grandifolia with blocky cankers (\%) & 0.051 & 0.254 & 0.289 & 0.463 \\
\hline Sand component of soil (\%) & 0.497 & 0.101 & 0.259 & 0.193 \\
\hline Clay component of soil (\%) & 0.656 & 0.058 & 0.253 & 0.071 \\
\hline Depth to water table $(\mathrm{cm})$ & 0.544 & 0.063 & 0.118 & 0.202 \\
\hline Prevailing wind (azimuth) & 0.105 & 0.259 & 0.407 & 0.132 \\
\hline
\end{tabular}


The parameters in Table 7 and associated loading values and Cryptococcus infestation or Neonectria infection were applied as predictors for the response Cryptococcus infestation or Neonectria infection in the following general linearized model for stepwise multiple regression:

$\mathrm{y}=\beta_{0}+\beta_{1}$ Climate, Soils, Stand Structure $+\beta_{1}$ Species Composition, Soil Profile $+\beta_{2}$ Stand Density and Structure, Wind Patterns $+\beta_{3}$ Bark Organisms, Climate, Forest Floor $+\beta$ Neonectria or Cryptococcus $+\beta_{4}($ Climate, Soils, Stand Structure)(Species Composition, Soil Profile) $+\beta_{5}($ Climate, Soils, Stand Structure)(Stand Density and Structure, Wind Patterns $)+\beta_{6}($ Climate, Soils, Stand Structure $)($ Bark Organisms, Climate, Forest Floor $)+$ $\beta_{7}$ (Climate, Soils, Stand Structure)(Neonectria or Cryptococcus) $+\beta_{8}$ (Species Composition, Soil Profile)(Stand Density and Structure, Wind Patterns) $+\beta_{9}$ (Species Composition, Soil Profile)(Bark Organisms, Climate, Forest Floor $)+\beta_{10}$ (Species Composition, Soil Profile)(Neonectria or Cryptococcus) $+\beta_{11}$ (Stand Density and Structure, Wind Patterns)(Bark Organisms, Climate, Forest Floor) $+\beta_{12}$ (Stand Density and Structure, Wind Patterns)(Neonectria or Cryptococcus) $+\beta_{13}$ (Bark Organisms, Climate, Forest Floor)(Neonectria or Cryptococcus $)+\beta_{14}($ Climate, Soils, Stand Structure)(Species Composition, Soil Profile)(Stand Density and Structure, Wind Patterns) $+\beta_{15}($ Climate, Soils, Stand Structure)(Species Composition, Soil Profile)(Bark Organisms, Climate, Forest Floor $)+\beta_{16}($ Climate, Soils, Stand Structure)(Species Composition, Soil Profile)(Neonectria or Cryptococcus) $+\beta_{17}$ (Species Composition, Soil Profile)(Stand Density and Structure, Wind Patterns)(Bark Organisms, Climate, Forest Floor) $+\beta_{18}$ (Species Composition, Soil Profile)(Stand Density and Structure, Wind Patterns)(Neonectria or Cryptococcus) $+\beta_{19}$ (Stand Density and Structure, Wind Patterns)(Bark Organisms, Climate, Forest Floor)(Neonectria or Cryptococcus) $+\beta_{20}$ (Climate, Soils, Stand Structure)(Bark Organisms, Climate, Forest Floor)(Neonectria or Cryptococcus) $+\beta_{21}$ (Climate, Soils, Stand Structure)(Stand Density and Structure, Wind Patterns)(Neonectria or Cryptococcus) $+\beta_{22}$ (Species Composition, Soil Profile)(Bark Organisms, Climate, Forest Floor)(Neonectria or Cryptococcus) $+\beta_{23}$ (Climate, Soils, Stand Structure)(Stand Density and Structure, Wind Patterns)(Bark Organisms, Climate, Forest Floor)(Neonectria or Cryptococcus) $+\beta_{24}$ (Climate, Soils, Stand Structure)(Species Composition, Soil Profile)(Stand Density and Structure, Wind Patterns)(Bark Organisms, Climate, Forest Floor) $+\beta_{25}$ (Climate, Soils, Stand Structure)(Species Composition, Soil Profile)(Stand Density and Structure, Wind Patterns)(Bark Organisms, Climate, Forest Floor) $+\beta_{26}($ Climate, Soils, Stand Structure)(Species Composition, Soil Profile)(Stand Density and Structure, Wind Patterns)(Neonectria or Cryptococcus) $+\beta_{27}$ (Species Composition, Soil Profile)(Stand Density and Structure, Wind Patterns)(Bark Organisms, Climate, Forest Floor) (Neonectria or Cryptococcus $)+\beta_{28}$ (Climate, Soils, Stand Structure)(Stand Density and Structure, Wind Patterns)(Bark Organisms, Climate, Forest Floor)(Neonectria or Cryptococcus) $+\beta_{29}($ Climate, Soils, Stand Structure)(Species Composition, Soil Profile)(Bark Organisms, Climate, Forest Floor) (Neonectria or Cryptococcus) $+\beta_{30}$ (Climate, Soils, Stand Structure)(Species Composition, Soil Profile)(Stand Density and Structure, Wind Patterns)(Bark Organisms, Climate, Forest Floor)(Neonectria or Cryptococcus) $+\varepsilon$

\section{Cryptococcus Infestation}

An initial stepwise multiple regression indicates significance in the whole model $(\mathrm{F}=4.130, \mathrm{df}=$ $92, \mathrm{p}<0.0001)$. Three latent variables and the interaction of two latent variables were significant for Cryptococcus infestation (Table 8). Plots of actual vs. predicted Cryptococcus infestation values and residuals vs. predicted infestation values indicate the regression model was unbiased (Figure 21). A fitted line and confidence interval plotted on actual vs. predicted values both cross 
the line for the mean indicating significant variation in the data. The residual plot forms a random cloud of points indicating no pattern among the differences between actual and predicted values that could skew results. These results indicate scale infestation may be affected by density, size, and height of both beech and non-beech species; species compositions of canopy strata; species diversity; bark organism; site related factors such as elevation, temperature, slope, and soils and the associated availability of water; and the interactions of some of these factors.

Table 8: Estimates for latent variables used to predict Cryptococcus infestation in an initial stepwise multiple regression.

\begin{tabular}{|c|c|c|c|c|}
\hline Intercept and Latent Variable & Estimate & $\begin{array}{c}\text { Standard } \\
\text { Error }\end{array}$ & $t$-ratio & $\begin{array}{c}\text { Probability } \\
t \\
\end{array}$ \\
\hline Intercept & 23.01542 & 4.28122 & 5.38 & $<0.0001 *$ \\
\hline Climate, Soils, Stand Structure & -0.00629 & 0.00205 & -3.06 & $0.0030^{*}$ \\
\hline Species Composition and Soil Profile & -0.00283 & 0.00336 & -0.84 & 0.4014 \\
\hline Stand Density and Structure, Wind Patterns & -0.07360 & 0.02474 & -2.98 & $0.0039 *$ \\
\hline Bark Organisms, Climate, Forest Floor & -0.00737 & 0.00241 & -3.06 & $0.0030^{*}$ \\
\hline Neonectria & -0.07199 & 0.05368 & -1.34 & 0.1837 \\
\hline (Climate, Soils, Stand Structure)x(Species Composition and Soil Profile) & 0.00001 & 0.00001 & 1.24 & 0.2177 \\
\hline (Climate, Soils, Stand Structure)x(Stand Density and Structure, Wind Patterns) & -0.00017 & 0.00011 & -1.59 & 0.1154 \\
\hline (Climate, Soils, Stand Structure)x(Bark Organisms, Climate, Forest Floor) & 0.00000 & 0.00000 & 4.53 & $<0.0001 *$ \\
\hline (Species Composition and Soil Profile)x(Bark Organisms, Climate, Forest Floor) & 0.00001 & 0.00001 & 1.17 & 0.2472 \\
\hline (Stand Density and Structure, Wind Patterns)x(Bark Organisms, Climate, Forest Floor) & -0.00019 & 0.00013 & -1.55 & 0.1251 \\
\hline (Stand Density and Structure, Wind Patterns)x(Neonectria) & -0.00741 & 0.00378 & -1.96 & 0.0532 \\
\hline (Climate, Soils, Stand Structure)x(Species Composition and Soil Profile)x(Bark Organisms, Climate, Forest Floor) & 0.00000 & 0.00000 & -1.98 & 0.0507 \\
\hline
\end{tabular}

*Indicates significance $(\alpha=0.05)$
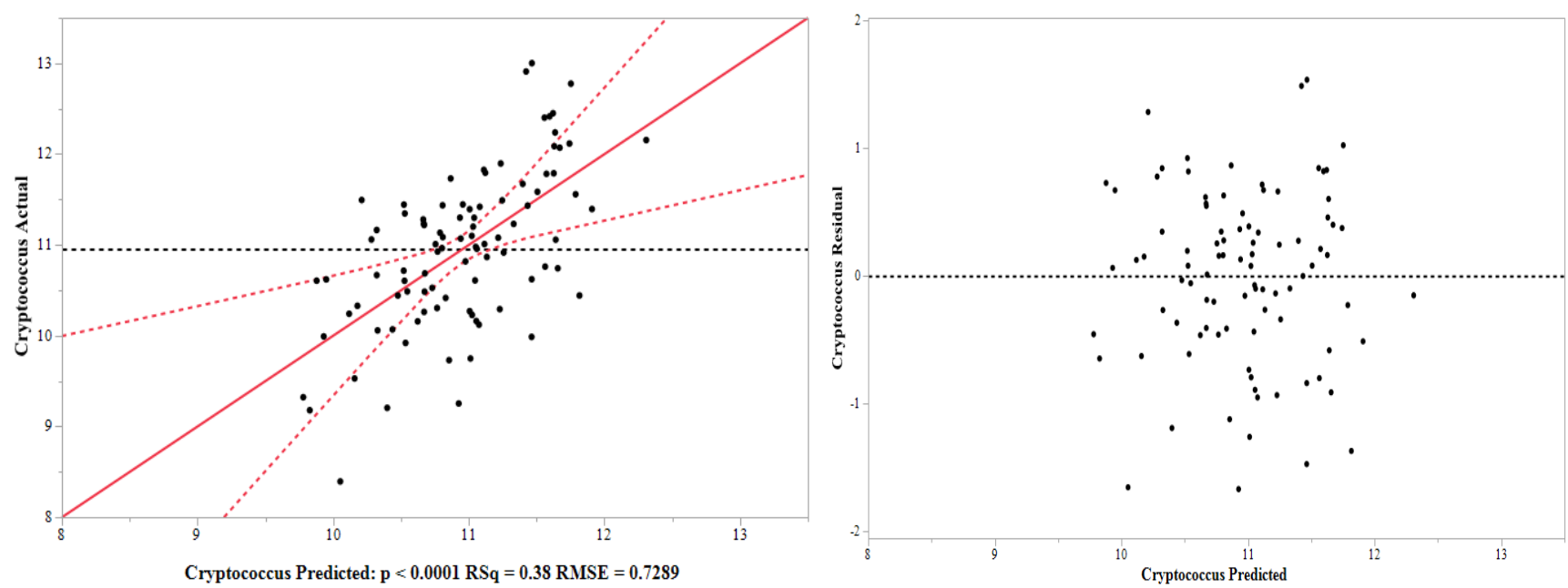

Figure 21: Actual vs predicted Cryptococcus infestation (left) and residuals of predicted Cryptococcus infestation values around the mean (right) for initial stepwise multiple regression. Dashed black lines are means; dashed red lines are the $95 \%$ confidence interval; solid red line is a fitted line.

A subsequent and ultimately final analysis applying significant latent variables and interactions identified by initial analysis as predictors for the response Cryptococcus infestation in the following general linearized model for stepwise multiple regression:

$y=\beta_{0}+\beta_{1}$ Climate, Soils, Stand Structure $+\beta_{2}$ Stand Density and Structure, Wind Patterns $+\beta_{3}$ Bark Organisms,

Climate, Forest Floor $+\beta_{4}$ (Stand Density and Structure, Wind Patterns)(Bark Organisms, Climate, Forest Floor) 
Results indicate significance in the whole model $(\mathrm{F}=5.712 \mathrm{df}=101, \mathrm{p}=0.0045)$. Two latent variables were significant (Table 9). Plots of actual vs. predicted Cryptococcus infestation values and residuals vs. predicted infestation values indicate the regression model is unbiased (Figure 22). Data in both plots were a bit more compressed on the $\mathrm{x}$-axis than in the initial regression reflecting the reduction in the number of predictors and loss of outlying data. A fitted line and confidence interval plotted on actual vs. predicted values both cross the line for the mean indicating significant variation in the data. The residual plot forms a random cloud of points indicating no pattern among the differences between actual and predicted values that could skew results. A contour plot and response surface show climate, soils, stand structure and bark organisms, climate, forest floor both have negative relationships with Cryptococcus infestation; as the influence of each latent variable increases infestation decreases (Figure 23). As did preliminary regression these results indicate density, size, and height of both beech and nonbeech species; species compositions of canopy strata; species diversity; bark organism; site related factors such as elevation, temperature, slope, and soils and the associated availability of water may influence infestation but the interactions of these factors are not as important.

Table 9: Estimates for latent variables used to predict Cryptococcus infestation in final stepwise multiple regression.

\begin{tabular}{rcccc}
\hline Intercept and Latent Variable & Estimate & Standard Error & $\boldsymbol{t}$-ratio & Probability $\boldsymbol{t}$ \\
\hline Intercept & 12.06170 & 0.34867 & 34.59 & $<0.0001^{*}$ \\
Climate, Soils, Stand Structure & -0.00197 & 0.00060 & -3.29 & $0.0014^{*}$ \\
Bark Organisms, Climate, Forest Floor & -0.00230 & 0.00070 & -3.27 & $0.0015^{*}$ \\
\hline
\end{tabular}
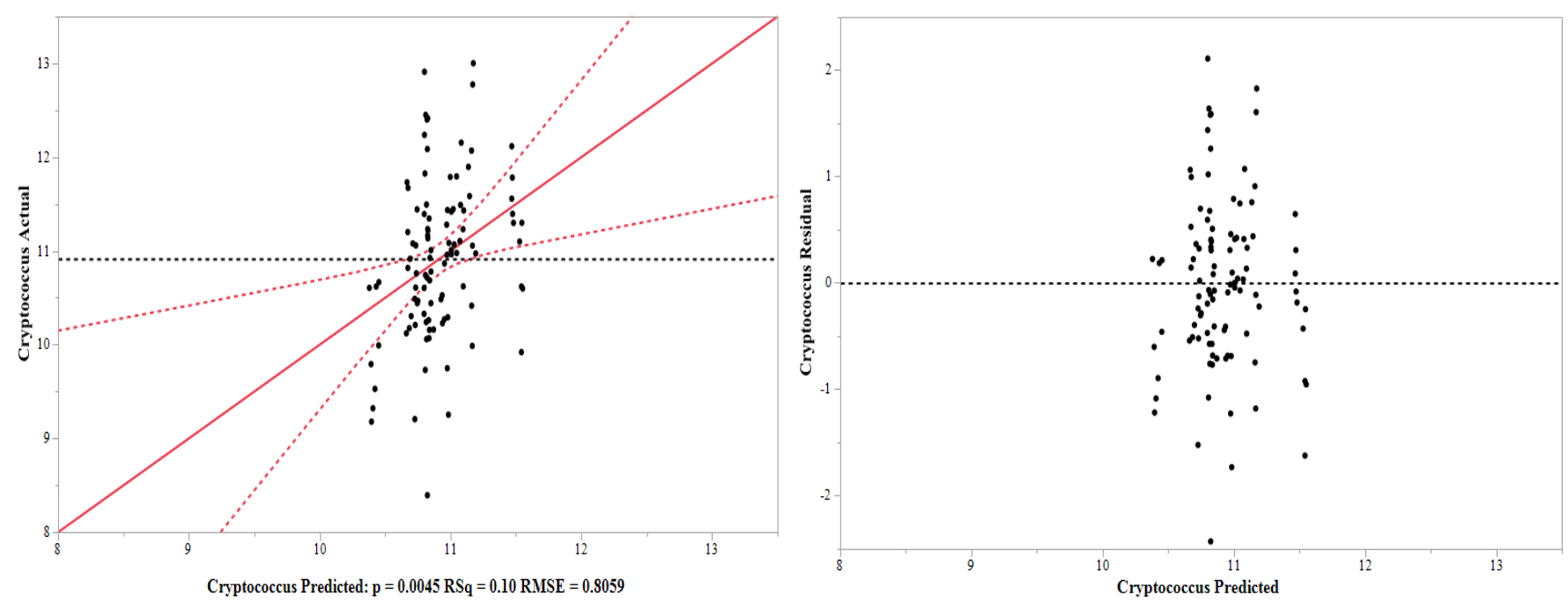

Figure 22: Actual vs predicted Cryptococcus infestation (left) and residuals of predicted Cryptococcus infestation values around the mean (right) for final stepwise multiple regression. Dashed black lines are means; dashed red lines are the $95 \%$ confidence interval; solid red line is a fitted line. 

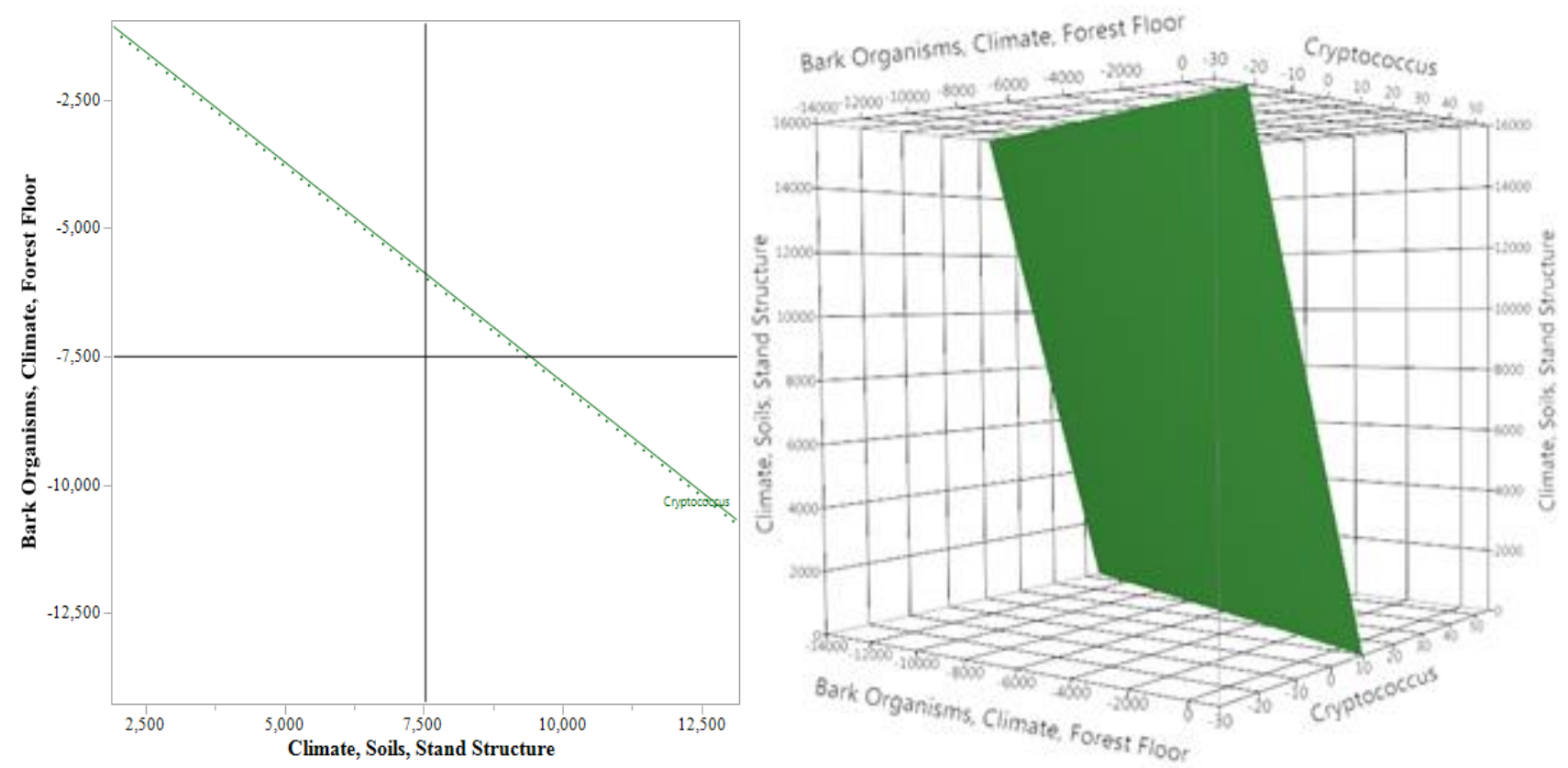

Figure 23: Contour plot and response surface for Cryptococcus infestation vs. climate, soils, stand structure and bark organisms, climate, forest floor.

\section{$\underline{\text { Neonectria Infection }}$}

An initial stepwise multiple regression indicates significance in the whole model $(\mathrm{F}=3.565$, $\mathrm{df}=$ 92, $\mathrm{p}<0.0001)$. Significant predictors included Cryptococcus and the interactions of several latent variables with one another and Cryptococcus (Table 10). Plots of actual vs. predicted Neonectria infection values and residuals vs. predicted infection values indicate the regression model was unbiased (Figure 24). A fitted line and confidence interval plotted on actual vs. predicted values both cross the line for the mean indicating significant variation in the data. The residual plot forms a random cloud of points indicating no pattern among the differences between actual and predicted values that could skew results. These results indicate Neonectria infection may be affected by scale infestation; density, size, and height of both beech and nonbeech species; overall stand density and DBH; species compositions of canopy strata; species diversity; bark organisms; site related factors such as elevation, temperature, slope, wind patterns and soils and the associated availability of water scale infestation. Results indicate also that the interactions of these factors may be more important for Neonectria infection than for scale infestation. 
Table 10: Estimates for latent variables used to predict Neonectria infection in an initial stepwise multiple regression.

\begin{tabular}{|c|c|c|c|c|}
\hline Intercept and Latent Variable & Estimate & $\begin{array}{l}\text { Standard } \\
\text { Error }\end{array}$ & $t$-ratio & Prob. $t$ \\
\hline Intercept & -32.49585 & 22.41419 & -1.45 & 0.1516 \\
\hline Climate, Soils, Stand Structure & 0.01532 & 0.00791 & 1.94 & 0.0568 \\
\hline Species Composition, Soil Profile & 0.00849 & 0.00848 & 1.00 & 0.3201 \\
\hline Stand Density and Structure, Wind Patterns & 0.03881 & 0.11696 & 0.33 & 0.7410 \\
\hline Bark Organisms, Climate, Forest Floor & 0.01777 & 0.00923 & 1.92 & 0.0585 \\
\hline Cryptococcus & 2.54460 & 1.18181 & 2.15 & $0.0348^{*}$ \\
\hline (Climate, Soils, Stand Structure)x(Species Composition, Soil Profile) & -0.00003 & 0.00005 & -0.59 & 0.5580 \\
\hline (Climate, Soils, Stand Structure)x(Stand Density and Structure, Wind Patterns) & -0.00354 & 0.00118 & -2.99 & $0.0039^{*}$ \\
\hline (Climate, Soils, Stand Structure)x(Bark Organisms, Climate, Forest Floor) & 0.00000 & 0.00000 & -1.46 & 0.1476 \\
\hline (Climate, Soils, Stand Structure) $\mathrm{x}($ Cryptococcus) & 0.00266 & 0.00770 & 0.34 & 0.7312 \\
\hline (Species Composition, Soil Profile)x(Stand Density and Structure,Wind Patterns) & -0.00407 & 0.00109 & -3.73 & $0.0004^{*}$ \\
\hline (Species Composition, Soil Profile)x(Bark Organisms, Climate, Forest Floor) & -0.00003 & 0.00005 & -0.56 & 0.5796 \\
\hline (Species Composition, Soil Profile)x(Cryptococcus) & 0.01051 & 0.00831 & 1.27 & 0.2099 \\
\hline (Stand Density and Structure, Wind Patterns)x(Bark Organisms, Climate, Forest Floor) & -0.00414 & 0.00138 & -2.99 & $0.0038^{*}$ \\
\hline (Stand Density and Structure, Wind Patterns)x(Cryptococcus) & -0.38776 & 0.12998 & -2.98 & $0.0039 *$ \\
\hline (Bark Organisms, Climate, Forest Floor)x(Cryptococcus) & 0.00320 & 0.00899 & 0.36 & 0.7226 \\
\hline $\begin{array}{r}\text { (Climate, Soils, Stand Structure)x(Species Composition, Soil Profile)x } \\
\text { (Stand Density and Structure, Wind Patterns) }\end{array}$ & -0.00001 & 0.00000 & -3.37 & $0.0012 *$ \\
\hline $\begin{array}{r}\text { (Species Composition, Soil Profile)x(Stand Density and Structure, Wind Patterns)x } \\
\text { (Bark Organisms, Climate, Forest Floor) }\end{array}$ & -0.00001 & 0.00000 & -3.41 & $0.0011^{*}$ \\
\hline (Species Composition, Soil Profile)x(Stand Density and Structure, Wind Patterns)x(Cryptococcus) & 0.00177 & 0.00123 & 1.44 & 0.1552 \\
\hline (Stand Density and Structure,Wind Patterns)x(Bark Organisms, Climate, Forest Floor)x(Cryptococcus) & 0.00152 & 0.00127 & 1.19 & 0.2372 \\
\hline (Climate, Soils, Stand Structure)x(Bark Organisms, Climate, Forest Floor)x(Cryptococcus) & 0.00000 & 0.00000 & 2.25 & $0.0279 *$ \\
\hline (Climate, Soils, Stand Structure)x(Stand Density and Structure, Wind Patterns)x(Cryptococcus) & 0.00130 & 0.00109 & 1.19 & 0.2366 \\
\hline $\begin{array}{r}\text { (Climate, Soils, Stand Structure)x(Stand Density and Structure, Wind Patterns)x } \\
\text { (Bark Organisms, Climate, Forest Floor) }\end{array}$ & 0.00000 & 0.00000 & 1.30 & 0.1990 \\
\hline $\begin{array}{r}\text { (Climate, Soils, Stand Structure)x(Stand Density and Structure, Wind Patterns)x } \\
\text { (Bark Organisms, Climate, Forest Floor)x(Cryptococcus) }\end{array}$ & 0.00000 & 0.00000 & -2.81 & $0.0065^{*}$ \\
\hline
\end{tabular}

*Indicates significance $(\alpha=0.05)$
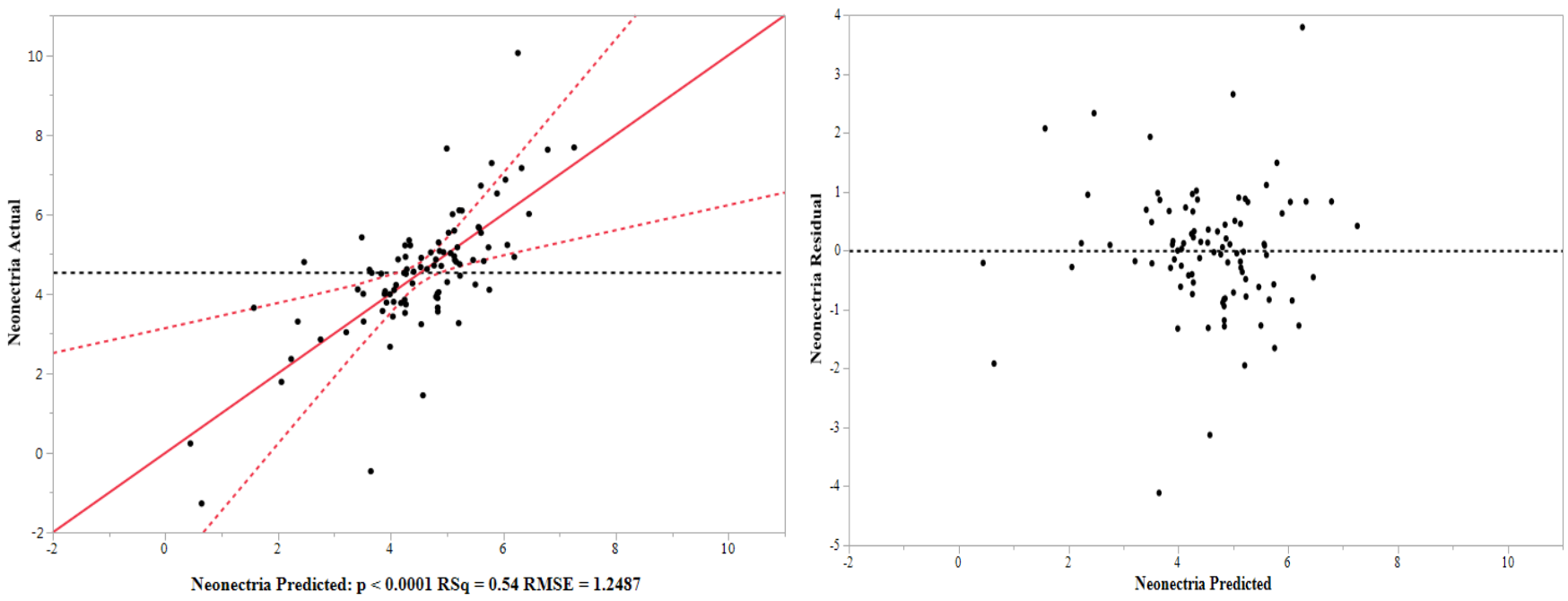

Figure 24: Actual vs predicted Neonectria infection (left) and residuals of predicted Neonectria infection values around the mean (right) for initial stepwise multiple regression. Dashed black lines are means; dashed red lines are the $95 \%$ confidence interval; solid red line is a fitted line. 
A subsequent and ultimately final analysis applying significant latent variables and interactions identified by initial analysis as predictors for the response Neonectria infection in the following general linearized model for stepwise multiple regression:

$\mathrm{y}=\beta_{0}+\beta_{1}$ Cryptococcus $+\beta_{2}($ Climate, Soils, Stand Structure $)($ Stand Density and Structure, Wind Patterns $)+\beta_{3}($ Species Composition, Soil Profile)(Stand Density and Structure, Wind Patterns) $+\beta_{4}$ (Stand Density and Structure, Wind

Patterns)(Bark Organisms, Climate, Forest Floor $)+\beta_{5}($ Stand Density and Structure, Wind Patterns)(Cryptococcus $)+$ $\beta_{6}$ (Climate, Soils, Stand Structure)(Species Composition, Soil Profile)(Stand Density and Structure, Wind Patterns) + $\beta_{7}$ (Species Composition, Soil Profile)(Stand Density and Structure, Wind Patterns)(Bark Organisms, Climate, Forest Floor) + $\beta_{8}\left(\right.$ Climate, Soils, Stand Structure)(Bark Organisms, Climate, Forest Floor)(Cryptococcus) $+\beta_{9}($ Climate, Soils, Stand Structure)(Stand Density and Structure, Wind Patterns)(Bark Organisms, Climate, Forest Floor)(Cryptococcus)

Results indicate significance in the whole model $(\mathrm{F}=10.277 \mathrm{df}=92, \mathrm{p}=0.0045)$. The interactions between Cryptococcus infestation and two latent variables, and the interactions between Cryptococcus infestation and three latent variables were significant (Table 11). Plots of actual vs. predicted Cryptococcus infestation values and residuals vs. predicted infestation values indicate the regression model was unbiased (Figure 25). As with Cryptococcus infestation, data in both plots were a bit more compressed on the $\mathrm{x}$-axis than in the initial regression reflecting the reduction in the number of predictors and loss of outlying data. A fitted line and confidence interval plotted on actual vs. predicted values both cross the line for the mean indicating significant variation in the data. The residual plot forms a random cloud of points indicating no pattern among the differences between actual and predicted values that could skew results. A contour plot and response surface show Cryptococcus x climate, soils, stand structure $\mathrm{x}$ bark organisms, climate, forest floor and Cryptococcus $\mathrm{x}$ climate, soils, stand structure $\mathrm{x}$ stand density and structure, wind patterns $\mathrm{x}$ bark organisms have a positive relationships with Neonectria infection; as the influence of the interactions increases infection increases (Figure 26). These results indicate infection may be affected by the interactions between scale and density, size, and height of both beech and non-beech species, species compositions of canopy strata, species diversity, bark organism, site related factors such as elevation, temperature, slope, and soils and the associated availability of water.

Table 11: Estimates for latent variables used to predict Neonectria infection in final stepwise multiple regression.

\begin{tabular}{|c|c|c|c|c|}
\hline Intercept and Latent Variable & Estimate & Standard Error & $t$-ratio & Probability $t$ \\
\hline Intercept & 4.04905 & 0.21188 & 19.11 & $<0.0001^{*}$ \\
\hline (Climate, Soils, Stand Structure)x(Bark Organisms, Climate, Forest Floor)x(Cryptococcus) & 0.00000 & 0.00000 & 2.49 & $0.0147 *$ \\
\hline $\begin{array}{r}\text { (Climate, Soils, Stand Structure)x(Stand Density and Structure, Wind Patterns)x } \\
\text { (Bark Organisms, Climate, Forest Floor)x(Cryptococcus) }\end{array}$ & 0.00000 & 0.00000 & -2.80 & $0.0062 *$ \\
\hline
\end{tabular}

$*$ Indicates significance $(\alpha=0.05)$ 

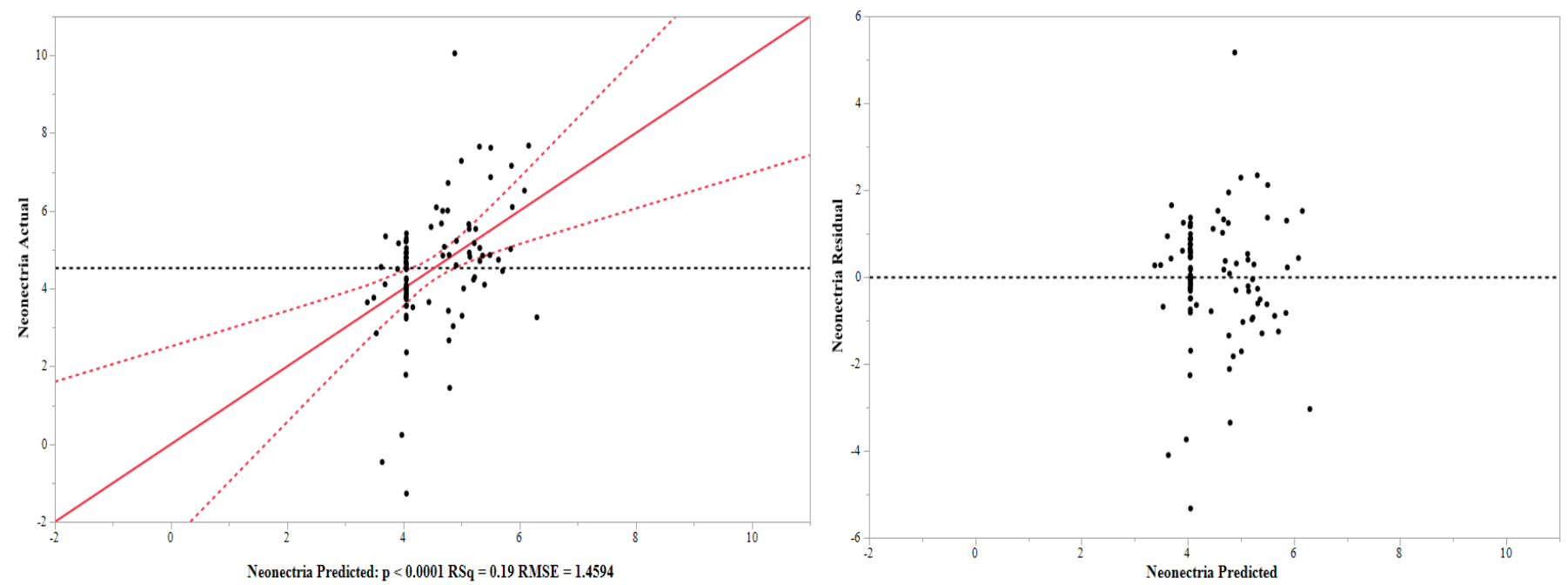

Figure 25: Actual vs predicted Neonectria infection (left) and residuals of predicted Neonectria infection values around the mean (right) for final stepwise multiple regression. Dashed black lines are means; dashed red lines are the $95 \%$ confidence interval; solid red line is a fitted line.
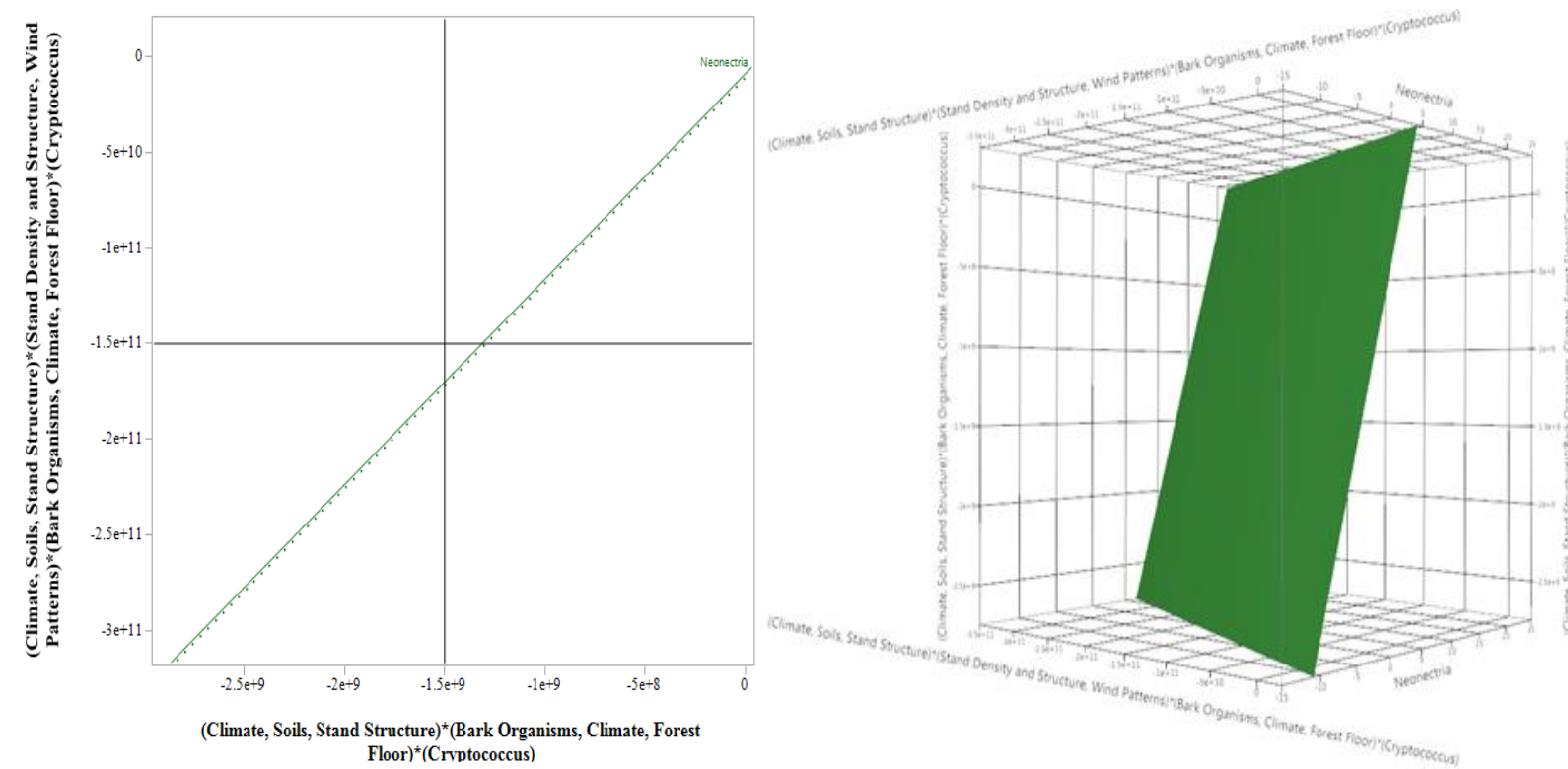

Figure 26: Contour plot and response surface for Neonectria infection vs. climate, soils, stand structure*bark organisms, climate, forest floor and climate, soils, stand structure*stand density and structure, wind patterns* bark organisms, climate, forest floor*Cryptococcus infestation.

\section{Spatial Analyses}

\section{Cryptococcus Infestation}

Scale infestation had spatial dependence at two sites (Table 12). Blackwater Falls II fit a Gaussian model (Figure 27 A) where samples within $215 \mathrm{~m}$ of one another are spatially dependent (variability explained $=79.2 \%$ ). Great Smoky Mountains National Park fit a spherical 
model (Figure $27 \mathrm{~B}$ ) where samples within $\sim 103.2 \mathrm{~m}$ of one another are spatially dependent (variability explained $=52.9 \%$ ). All other sites fit nugget or linear models that represent no spatial dependence.

Table 12: Semivariogram parameters for Cryptococcus infestation at study sites in the Appalachian region.

\begin{tabular}{lclccccc}
\hline \multicolumn{1}{c}{ Site } & Mean & $\begin{array}{c}\text { Semivariogram } \\
\text { Model }\end{array}$ & Nugget & Sill & $\begin{array}{c}\text { Range } \\
\text { (m) }\end{array}$ & $\begin{array}{c}\text { \% Variability } \\
\text { Explained by } \\
\text { Spatial } \\
\text { Dependence }\end{array}$ & $\boldsymbol{r}^{\mathbf{2}}$ \\
\hline Allegheny National Forest & 1.42 & Nugget & 0.382 & 0.382 & N/A & N/A & 0.000 \\
Beverly, WV I & 0.20 & Nugget & 0.680 & 0.680 & N/A & N/A & 0.000 \\
Blackwater Falls II & $\mathbf{0 . 1 5}$ & Gaussian & $\mathbf{0 . 1 7 8}$ & $\mathbf{0 . 8 5 7}$ & $\mathbf{2 1 5 . 8}$ & $\mathbf{7 9 . 2}$ & $\mathbf{0 . 9 3 6}$ \\
Blackwater Falls III & 0.04 & Nugget & 0.449 & 0.449 & N/A & N/A & 0.439 \\
Cranberry Wilderness & 1.49 & Linear & 0.676 & 1.096 & N/A & N/A & 0.688 \\
Dolly Sods I & 0.84 & Nugget & 0.626 & 0.626 & N/A & N/A & 0.000 \\
Dolly Sods II & 1.35 & Nugget & 0.362 & 0.362 & N/A & N/A & 0.570 \\
Gaudineer Scenic Area & 1.00 & Linear & 0.208 & 0.320 & N/A & N/A & 0.434 \\
Kumbrabow State Forest & 1.33 & Linear & 0.593 & 0.597 & N/A & N/A & 0.000 \\
Middle Mountain & 1.35 & Linear & 0.460 & 0.594 & N/A & N/A & 0.343 \\
Shaver's Fork & 1.14 & Nugget & 0.084 & 0.084 & N/A & N/A & 0.000 \\
Great Smoky Mountains & $\mathbf{0 . 7 0}$ & Spherical & $\mathbf{0 . 2 4 7}$ & $\mathbf{0 . 5 2 4}$ & $\mathbf{1 0 3 . 2}$ & $\mathbf{5 2 . 9}$ & $\mathbf{0 . 5 3 7}$ \\
\hline
\end{tabular}

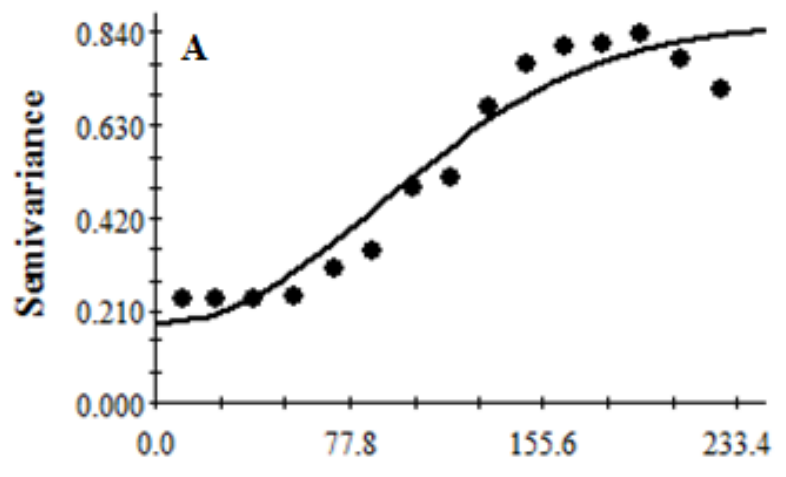

Lag Distance (m)

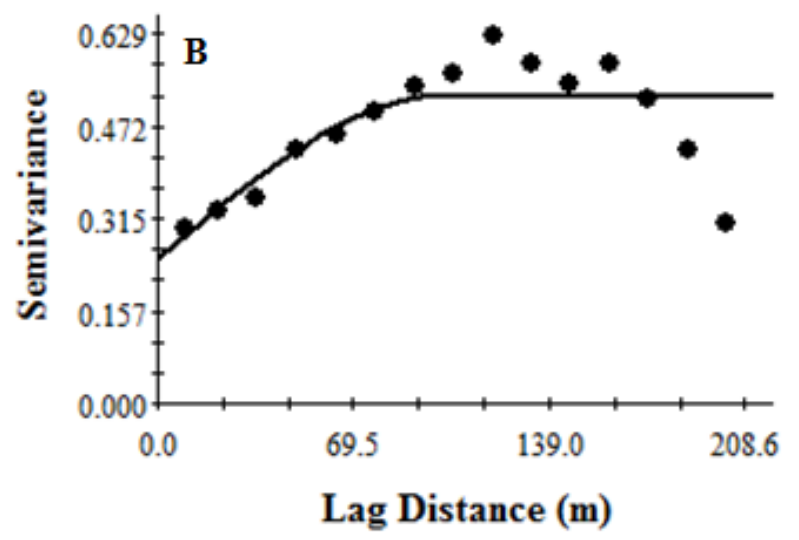

Figure 27: Spatial structures of Cryptococcus infestation at Blackwater Falls State Park II, WV (A) and Great Smoky Mountains National Park, TN (B).

\section{$\underline{\text { Neonectria Infection }}$}

Neoenctria infection had spatial dependence at two sites (Table 13). Allegheny National Forest fit an exponential model (Figure $28 \mathrm{~A}$ ) where samples within $\sim 123.6 \mathrm{~m}$ of one another are spatially dependent (variability explained $=68.6 \%$ ). Cranberry wilderness fit a Gaussian model (Figure $28 \mathrm{~B}$ ) where samples within $\sim 32.9 \mathrm{~m}$ of one another are spatially dependent (variability explained $=60.9 \%$ ). All other sites fit nugget or linear models that represent no spatial dependence. 
Table 13: Semivariogram parameters for Neonectria infection at study sites in the Appalachian region.

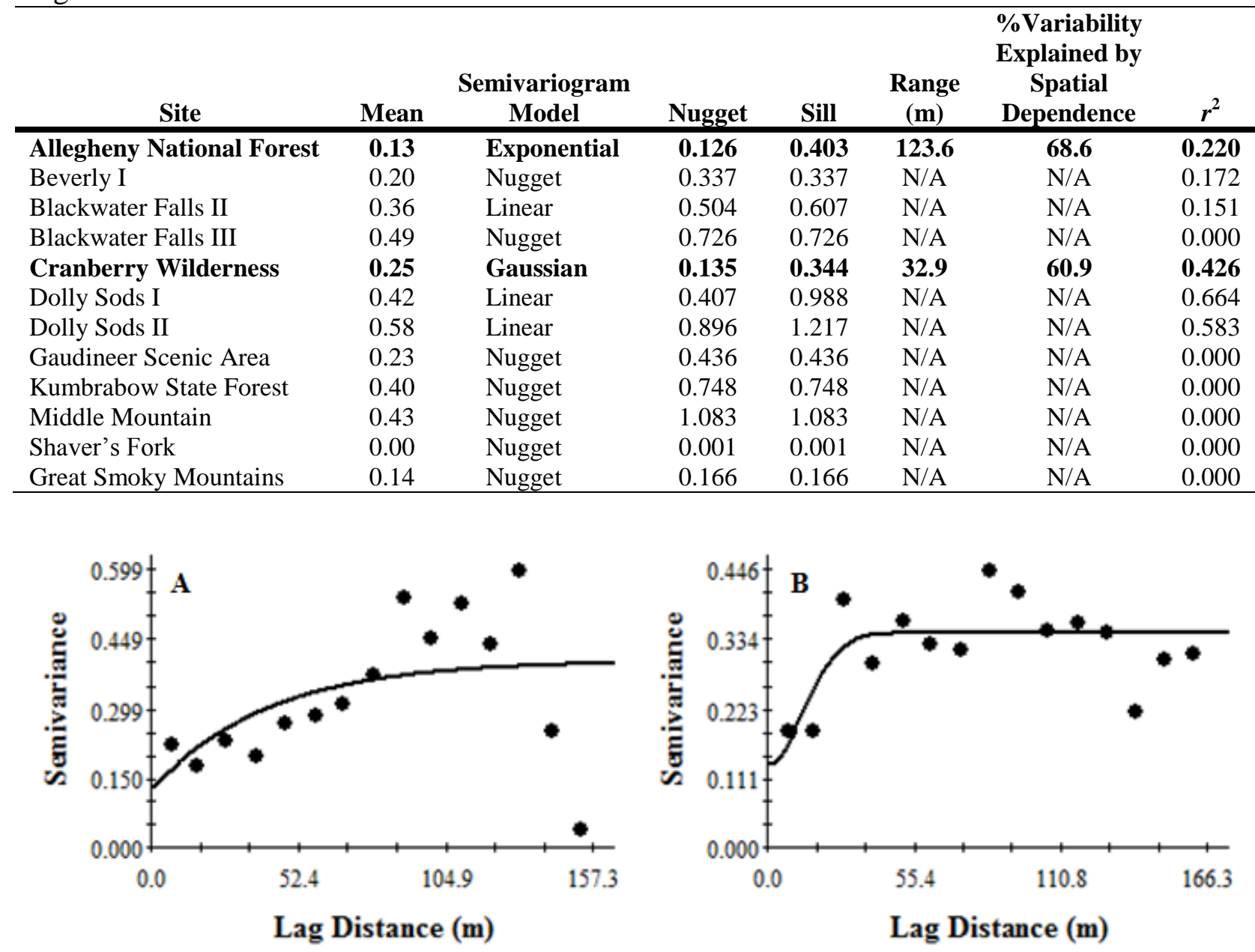

Figure 28: Spatial structures of Neonectria infection at Allegheny National Forest, PA (A) and Cranberry Wilderness, WV (B).

\section{Discussion}

\section{Cryptococcus Infestation and Neonectria Infection}

Cryptococcus infestation and Neonectria infection were negatively correlated (-0.068). Most study plots where located in what would be expected to be aftermath zones based on long histories of BBD. Shigo (1972) describes aftermath zones as having decreasing and endemic scale populations giving way to heavy Neonectria infection and widespread past mortality. Negative correlation between causal agents could then be expected. Furthermore, Long histories of disease are reflected in CWD and SCWD loads. Beech dominated sample plots and there some heavily infected trees and mortality as evidenced by the proportion of beech accounting for CWD and SCWD. Morphological and molecular identifications of perithecia collected at each site indicate Neonectria faginata is the predominant species on beech at study sites. Predominance of $N$. faginata indicates an extended period of BBD activity (Houston, 1994a; Kasson and Livingston, 2009). 
Some plots where located in Holden Arboretum and the Great Smoky Mountains in remote pockets of disease that had relatively low infestation and infection ratings. These are indicative of the advancing front described by Shigo (1972) as having low levels of causal agents. Overall Shigo's characterization of BBD progression appears reliable, but the effects of environment may produce variations in observed levels of causal agents. Furthermore, the spread of BBD overall is not definitively frontal in nature as described by Shigo, however outlying disease centers indicate disease spread occurs as epicenters coalesce to produce larger areas representative of the different zones of disease described by Shigo.

Regression analyses suggest scale infestation is important for Neonectria infection. Garnas (2009) and Cale et al. (2012) assert that infection is not significantly related to infestation. Garnas' data was based on using wax tufts as a surrogate for scale population size. Cale's observations were made with imagery on a very limited number of beech. The pitfalls of evaluating densities of causal agents without corroborative quantification are obvious. The area of wax covering produced by adult scales is not necessarily indicative of population size, and without counting actual scales or eggs no conclusion about the population size can be made. Data reported in this study where estimates for trees and plots were obtained from actual counts of scale insects and Neonectria cankers should be more reliable.

\section{$\underline{\text { Stand Features }}$}

Variation in beech proportions, height, DBH, and basal area were well explained by PCA. All of those factors except beech DBH were part of latent variables significant for infestation in regression, and all including beech DBH were part of latent variables significant for infection in regression. Descriptive data suggest red spruce and yellow birch decrease or are absent at higher infestation ratings. The red spruce proportions in total and in all canopy strata, total and intermediate yellow birch proportions, total and dominant black cherry proportions, and BAF also were well explained by PCA. All of these factors minus black cherry parameters were included in latent variables significant for infestation while all were included in latent variables significant for infection. Total proportions of red oak and red maple, and proportions of intermediate red maple were included in latent variables significant for infestation and infection. Proportions of dominant and co-dominant red maple and proportions of intermediate sugar maple were part of latent variables significant for infection.

Beech per hectare, proportions of total and intermediate yellow birch, proportions of red spruce in total, in all strata, and in SCWD, proportion of intermediate red maple, total species and tree diversities, and total species evenness have negative correlation with scale infestation.

Proportions of total and co-dominant beech, beech basal area and height, non-beech species $\mathrm{DBH}$, height, and per hectare, total proportion of red oak, BAF, and tree species evenness have positive correlation with infestation (Appendix 4, Table 1).

Beech total proportion, DBH, basal area and height; non-beech basal area and height; overall proportion of yellow birch; proportions of co-dominant, intermediate and SCWD red spruce; proportions of red maple total, dominant, co-dominant, intermediate red maple; proportion of intermediate sugar maple; total and dominant black cherry proportions; total proportion of red oak; BAF; total species and tree diversities; and total species evenness have negative correlation 
with Neonectria infection. Overall proportion of beech and beech per hectare; non-beech species per hectare; proportion of intermediate yellow birch; proportions of red spruce overall and in suppressed stratum; and tree species evenness have positive correlation with infection(Appendix 4, Table 1).

Beech scales are positively phototaxic and predominantly dispersed by wind between and within stands (Gate, 1988), so species composition of a stand and canopy strata may affect their dispersal and distribution. Neonectria inoculum also is predominantly dispersed by wind between and within stands. Splashing water may disperse inoculum of both agents within stands. Gove and Houston (1996) reported a general delay in progression of disease from co-dominant to intermediate beech classes. Negative correlation for both infestation and infection with dominant and co-dominant proportions of red spruce and red maple indicates these species may disrupt inoculum dispersal between stands. Negative correlation for both infestation and infection with intermediate red spruce and red maple indicate red spruce and red maple may disrupt the spread of inoculum within a stand.

Proportion of intermediate yellow birch has a negative correlation with infestation but a positive correlation with infection and total proportion of yellow birch has negative correlation with both infestation and infection. These data and the variation in correlation between infestation and infection and other parameters describing non-beech species components suggest non-beech species may filter out dispersing beech scales and Neonectria inoculum and prevent them from landing on a beech host. Positive and negative correlation between BAF and infestation and infection, respectively, indicate dense stands may favor scale infestation and dispersal, whereas they may hinder Neonectria infection and dispersal.

Positive correlations for infestation with beech proportion, height and basal area suggest more scale inoculum may be intercepted by beech when they are large, tall and more abundant. Positive correlations for infection with beech proportion, and beech per hectare but negative correlations for infection with beech basal area, and height indicate the abundance of beech facilitates fungal inoculum distribution, perhaps both between and within stands, more than beech size. Negative correlations for both infestation and infection with total species evenness, and total species and tree species diversity indicate more diverse stands, presumably with relatively less beech, limit the dispersal of inoculum or contact of causal agents with a beech host. These data coupled with positive correlations for both infestation and infection with tree species evenness and beech proportions merely may reflect expected situations where more beech hosts result in greater levels of disease; however, it also may reflect a reduction of inoculum loads that could be expected in stands with less beech.

Although beech height was positively correlated with infestation and taller beech are inherently larger in diameter, smaller diameter beech were observed during this study to be infested at least as often as larger diameter beech. Previous research indicates beech scale prefers vigorous, larger diameter and older trees that provide more feeding opportunities and improved nutrient availability (Ehrlich, 1934; Mize and Lea, 1979; Latty et al., 2003). However, mortality rates are highest among large trees of low vigor (Mize and Lea, 1979). Results of past research suggesting larger beech are preferred may be the result of infested smaller beech being quickly removed from the landscape. Sap-feeding insects favor stressed hosts (Galway et al., 2004). Smaller, perhaps stressed beech may incur heavy infestations more readily. Heavy infestations may 
further weaken trees and reduce growth, rendering them more susceptible to invasion by any number of fungi (Ehrlich, 1934). Beech wood decays rapidly when exposed to microorganisms (Scheffer and Cowling, 1966). The infestation of smaller beech may not be noticed over time as they die and quickly decay. Furthermore, if smaller infested beech quickly die, it may reduce the pool of scale inoculum in a stand by limiting the next generation.

Species composition and the resulting litter may affect nutrient cycling. Decomposition rates and the nutrients released among tree genera and species vary in Appalachian hardwood stands (Gosz, et al., 1973; Blair, 1988; Adams and Angradi, 1996). The translocation of nutrients, more precisely nitrogen, shuttled from leaves prior to abscission may vary with genus and species. Research indicates litter of maple species may retain more nitrogen relative to other hardwood species (Blair, 1988; Adams and Angradi, 1996). Perhaps stands with more maple recycle nitrogen more slowly and affect nitrogen content of beech bark which, as discussed below, is a key factor for scale and Neonectria development. Also, large non-beech species may sequester nutrients away from beech and could influence microclimates by virtue of their distribution, size, and stratum.

The effects of stand features may not entirely exclude either disease agent, but they could limit their development or dispersal enough to have an influence on BBD incidence or severity. Garnas et al. (2012 and 2013) infer species compositions and stand characteristics are not drivers in the BBD complex. However, differences in disease related to species composition and stand structure have been observed in North America. Stands in New England dominated by hemlock had more beech affected by BBD (Twery and Patterson, 1983 and 1984). Larger stressed beech in North America tend to have higher mortality rates (Mize and Lea, 1979), perhaps because they are in higher canopy classes and intercept inoculum more often. Data from Leak (2006) suggest reducing yellow birch may reduce disease.

Data from this study suggest stand features have an influence on the incidence and severity of $\mathrm{BBD}$, the efficacy of which may vary with species composition overall and in canopy strata. Furthermore, stand structure and species composition could influence microclimates or nutrient cycling that hinder or favor beech scale or Neonectria development.

\section{Forest Floor Components}

Parameters with variation well explained by PCA in significant latent variables and related to forest floor components include clay and sand components of soil, depth of soil E horizon, stone surface cover, and depth to water table. All these parameters except thickness of E horizon where part of latent variables significant for infestation in regression, while all where part of latent variables significant in regression for infection.

Sand in soil, depth to water table, and E horizon thickness have negative correlation with infestation; stone surface cover and clay in soil have positive correlation with infestation. Clay and sand in soil have negative correlation with infection; stone surface cover, depth to water table, and thickness of E horizon have positive correlation with infection. Soil E horizons generally are sandy in nature and leached of nutrients. 
Negative correlation for infestation with sand in soil, depth to water table, and E horizon thickness suggest dry soils inhibit infestation; positive correlation between stone surface cover, clay in soil and infestation further supports inhibition of infestation by dry soils. The effects of these parameters on Neonectria infection are not as decisive. Sand and clay both have negative correlation with infection suggesting soil moisture is not as important to infection as it is to infestation. Depth to water table and soil E horizon thickness having positive correlation with infection further support this. Soil conditions seem not to have effects on infection that are as definitive as for infestation, however, there also is no indication that infection is absolutely unrelated to soils. Therefore, the generalization that fungal infection is favored by moist, cool conditions could be asserted. Furthermore, Neonectria is well known to be dependent on scale infestation and the establishment of an infestation may partially override any influences that soils and water availability have on infection.

Clay soils retain moisture more readily than sandy soils. In the soil triangle as one proportion increases the others either remain unchanged or decrease. Data in this study reflecting increased clay proportions may essentially be construed as also reflecting lower proportions of sand. Changes in bark chemistry related to infection by decay fungi seem to inhibit scale infestation while favoring Neonectria infection (Cale et al., 2015). Soil composition could influence bark chemistry and render beech at certain sites more or less susceptible to scale infestation or Neonectria infection based on available nutrients that may favor or limit infestation or infection. Sap-sucking insects are attracted to hosts under stress (Galway et al., 2004). Drought stress has been reported to increase disease, especially with particular soil conditions (Lonsdale, 1980; Parker, 1983; Perrin, 1983).

Establishment of sap-sucking insects is limited by low amino nitrogen content (Dadd and Mittler, 1965). Low total and amino nitrogen is a characteristic of asymptomatic trees (Wargo, 1988). High nitrogen content in old-growth relative to second-growth beech is associated with increased disease severity (Latty et al., 2003; Latty, 2005). Nitrogen also is a key nutrient for fungal growth (Alexopoulos, 1996). Neonectria fungi are poor pathogens that opportunistically infect wounded or stressed trees (Manion, 1991). Mild cases of nutrient or water stress may render beech less palatable to scales or Neonectria fungi. Slightly stressed beech may have just enough defenses to hold off severe infection along with a deficiency in nutrients that makes them inferior hosts. Beech is known to prefer moist soils. Well-drained sandy soils may leach key nutrients such as nitrogen out of sites, limiting the establishment of beech scale or Neonectria on bark of trees not necessarily under drought stress.

Similarly, soil profiles with deep water tables may not hold enough water to support the most suitable hosts. Conversely, landscapes with large stones at/near the surface may pool water or clay dominated soils may hold water and nutrients more efficiently to the benefit of beech scale or Neonectria fungi. The maps of Blackwater Falls-I (Appendix 1, Figures 8 and 9) indicate two hot spots of increased infestation and the same locations also are hot spots of increased infection. Although not obvious on the maps these areas were observed during sampling to be the lowest lying and wettest on site. Soils also may have an effect on stand structure and species composition, which appear to be important factors for both causal agents of BBD. 


\section{Landscape and Topography}

Parameters with variation well explained by PCA in significant latent variables and related to landscape and topography include slope, elevation, frost free days (FFD), growing degree days (GDD), temperature, prevailing wind, beech with A. rugosa, and beech with blocky cankers (blocky cankers and A. rugosa will be addressed in more detail in Chapter 3). All these parameters except prevailing wind were part of latent variables significant for infestation in regression and all were part of latent variables significant for infection.

Elevation, slope, and FFD have negative correlation with infestation while GDD, temperature, beech with A. rugosa, and beech with blocky cankers have positive correlation with infestation. Slope, FFD, GDD, temperature, beech with A. rugosa, and beech with blocky cankers have negative correlation with infection; elevation and prevailing wind have positive correlation with infection.

Negative correlation for infestation with FFD but positive correlation with GDD and temperature indicates warm climates favor scale while cold climates may be limiting. Negative correlation for infestation with elevation indicates moisture or temperature may be an influence. Data from this study already suggests scale infestation may be favored by moist environments and higher elevations may tend to be drier and cooler. Also, steeper slopes may tend to be drier and limiting for infestation.

Negative correlations for infection with FFD, GDD, and temperature indicate warm, dry conditions hinder Neonectria development. This could be expected given fungal development commonly is favored by cool, moist environments. Although higher elevations tend to be drier, they do experience periodic events of elevated moisture when squeezing precipitation out of storm clouds. These wet periods may provide enough moisture on stems to promote rapid development of Neonectria and increases in disease incidence and severity. Wind data was analyzed as azimuth direction; a positive correlation between wind and infection indicates winds out the west and north promote infection. Negative correlation for infection with slope indicates steeper slopes experience less infection. This could be due to interactions between wind and slope as inoculum is swept up and over windward facing steep slopes, or conversely as inoculum is swept over leeward facing steep slopes and deposited on gentle slopes and in valleys. Such phenomena may also result in ridgetops experiencing less disease as inoculum is swept over. Steep slopes more exposed to sun and wind and susceptible to water runoff would likely be drier, warmer environments that hinder either causal agent.

Plots at Great Smoky Mountains (GSM) and Shaver's Fork (SF) were on ridgetops (Appendix 1, Figures 22 and 23; Figures 30 and 31, respectively); GSM has steep slopes to the north and south and SF has a steep slope to the west. According to NOAA data prevailing winds come out of the southwest at GSM while at SF they come from the northwest. These sites had the some of the lowest mean infestation ratings (Table 15) and infection ratings (Table 16). Data from GSM may indicate an advancing front with expected low levels of disease agents, but SF is in an aftermath zone.

Some researchers have attributed differences in disease progression to site or climate conditions (Ehrlich, 1934; Houston et al., 1979; Parker 1980, 1983; Lonsdale, 1980; Houston and Valentine, 
1988; Perrin, 1983; Houston et al., 2005). Gove and Houston (1996) observed more rapid disease progression in increment cores of more northerly sites relative to southern sites. Somewhat conversely, extreme cold temperatures are lethal to beech scale (Barter, 1953), and infestation has been found to be reduced with extended periods of low temperatures (Houston and Valentine, 1988; Kasson and Livingston, 2012).

This study suggests warm climates also may be a limiting factor. Milder climates with fewer extremely cool or warm periods may be optimum for beech scale infestation. The range of BBD is already being defined by cold temperatures to the north in Canada, and warmer temperatures presumably will limit its incidence or severity to the south and west. However, local climatic and topographic features may create microclimates that affect scale or Neonectria dispersal and establishment. In a more than twenty year study Houston et al. (2005) observed differences in disease progression on sites only a few miles apart and attributed these differences to site conditions. Outlying pockets of BBD in the South and Midwest may be indicative of sites that have ideal conditions for scale infestation. These sites may eventually be epicenters for widespread infection, or they may prove to be hot spots of increased disease at the fringes of the range of BBD in North America.

\section{Spatial Analyses}

Spatial dependence occurs when the infestation or infection of individuals, in this study beech trees, is a function of their proximity to one another. In spatial analyses range is the distance at which that dependence may be active. Spatial analyses indicate Cryptococcus infestation has spatial dependence at the Blackwater Falls II (BW-II) and Great Smoky Mountains (GSM) sites. Neonectria infection has spatial dependence at the Allegheny National Forest (ANF) and Cranberry Wilderness (CB) sites. The distance for spatial dependence (range) is much greater at BW-II vs. GSM (Table 11), and at ANF vs. CB (Table 12). Houston and Houston (2000) found spatial relationships in disease related to genetic diversity. Putatively resistant American beech had consistently reduced heterozygosity in alleles relative to susceptible individuals. Groups of beech that exhibit resistance may result not only from root sprouting that is prolific in beech but also from seed that are homozygous in resistance alleles. Conversely, Houston et al. (1979a) found that distance from an inoculum source was important for scale infestation, it may be inferred that there are environmental and site factors that influence variation in that distance.

Neonectria infection is dependent on scale infestation. Data in this study suggest there is less infestation with more intermediate red spruce and red maple. Red spruce is absent at BW-II, ANF, and CB but present at GSM (14.4\% total red spruce). At CB vs. ANF there are greater proportions of intermediate red maple (2.8\% vs. $0.0 \%)$ and total red maple (10.7\% vs. $2.1 \%)$. However, intermediate red maple is absent at BW-II and essentially so at GSM $(0.3 \%)$ while total red maple is more abundant at BW-II than GSM (14.8\% vs. $1.5 \%)$. Differences in spatial dependence among these pairs of sites perhaps reflect a situation where non-beech tree species intercepting inoculum of either disease agent spreading from a source tree. Although red maple may not be contributing to this difference at GSM relative to BW-II there may be red spruce and other species intercepting inoculum.

Data from this study indicate clay (positive correlation with infestation) and depth to water table (negative correlation with infestation) affect scale infestation. The indication is more available 
water seems to favor infestation. There is more clay in soil at BW-II than at GSM (20\% and $10 \%$, respectively) and at ANF than at CB (30\% and 20\%, respectively). There also is a shallow water table at ANF relative to CB (39cm vs. $216 \mathrm{~cm}$, respectively). However, these depths are the same at BW-II and GSM. Still, these soil and hydrology factors may facilitate a greater distance for spatial dependence at BW-II and ANF. Scales dispersing from an inoculum source may need to travel a longer distance at these sites to find a suitable host based on available water for hosts.

\section{Conclusions}

Genetics are expectedly the driving factor in host tree responses to attacks by disease agents. The concept of ecological resistance tries to account for the influence of ecological factors, but those factors often are responsible for triggering, or not, a genetic response by the host. However, it is widely accepted that stressors, such as drought, do render host trees more susceptible to disease agents as described by Manion (1991) and the concept of the death spiral. This concept can be extended to ecological factors that may not induce severe stress to a host but contribute to the survival, distribution, and efficacy of causal agents as well as the response by a host whether it be genetically driven or not. In short, the presence of inherited resistance does not by any means exclude the influences of environment on disease incidence and severity.

In this study PCA was used to emphasize variation in a large number of ecological parameters and identify latent variables that describe patterns in the data. Loading values identified parameters whose variation is best explained by PCA. Latent variables composed of parameters best explained by PCA then were used as predictors in regression. Correlations were used to characterize the relationships of parameters in latent variables with the responses scale infestation and Neonectria infection. Ultimately there was no single factor that could be pointed to as a cause for the apparent limiting of BBD at these study sites. Numerous factors including partial inherited resistance likely are acting in concert to influence disease progression. Garnas et al. (2012 and 2013) suggest climate and site characteristics do not significantly contribute to BBD development, while citing disease ontogeny and time since disease introduction as primary factors. Disease development beyond introduction is undeniably influenced, as well as introduction itself, by environment and ecology or more specifically climate and species interactions.

Data in this study reveals relationships with climate related factors such as elevation, frost free days, slope, and wind patterns. The northern limit of beech scale has been established along the Canada-United States border by cold climates. The southern limit is currently being established by warm climates as beech scales spreads south. As beech scale fully establishes a range in North America stands at the fringes of its distribution should exhibit less disease incidence and severity due to conditions that limit infestation. Furthermore, this research suggests beech more often remains disease-free in stands with sandy soils that retain less water. Ridge-tops and steep slopes, that present drier conditions likely will experience less disease than low lying moist areas. Also, stands with higher proportions of red spruce, red maple, and associated stand structures may limit the establishment of BBD causal agents by affecting their dispersal or creating unfavorable microenvironments.

This study tried to illuminate how variations in landscape and environment can influence BBD incidence and severity. Specifically, it endeavored to identify site factors associated with 
putatively resistant beech. Ultimately, only a handful of the over 100 parameters evaluated may affect the causal agents of BBD. However, there are some directions that any future studies could take. A more focused study of species compositions may find species that intercept inoculum, induce microclimates enhancing the effects of growing degree and frost free days, or that may be associated with non-beech height and density. Other studies may more closely investigate the effects of soil properties on bark chemistry and the ability of scales or fungal inoculum to colonize beech bark, particularly among the presence of other bark organisms.

\section{Chapter 3: Blocky Canker Study}

\section{Background}

Species of Fusarium cause cankers on numerous hardwoods including maples (Skelly and Wood, 1966), cottonwoods (Toole, 1963) and oaks (Toole, 1966). They have been isolated from bark of American beech but not associated with cankers (Cotter and Blanchard, 1982; Sinclair and Lyon, 2005). Blocky, cracked cankers regularly have been observed in the Appalachian region on beech stems affected or unaffected by beech bark disease (Figure 29). These cankers are similar to those found on maples (Figure 30) and cause discoloration in sapwood of beech (Figure 31). However, they do not kill the cambium as evidenced by sprouts growing out of cankers (Figure 32). Furthermore, the blocky cankers seem to exclude or limit Neonectria infection (Figure 33), and whenever Neonecetria perithecia are seen on the cankers the perithecia are dead (Figure 34). In contrast, the blocky cankers do not exclude beech scale (Figure 35). Analyses of ecological factors above indicate blocky cankers may be important for BBD establishment; the proportion of plots at sites with blocky cankers was found to be a significant, positively correlated factor for scale infestation. However, blocky cankers were negatively correlated with but not significant for Neonectria infection. Given this information, further investigation into the blocky cankers is warranted.

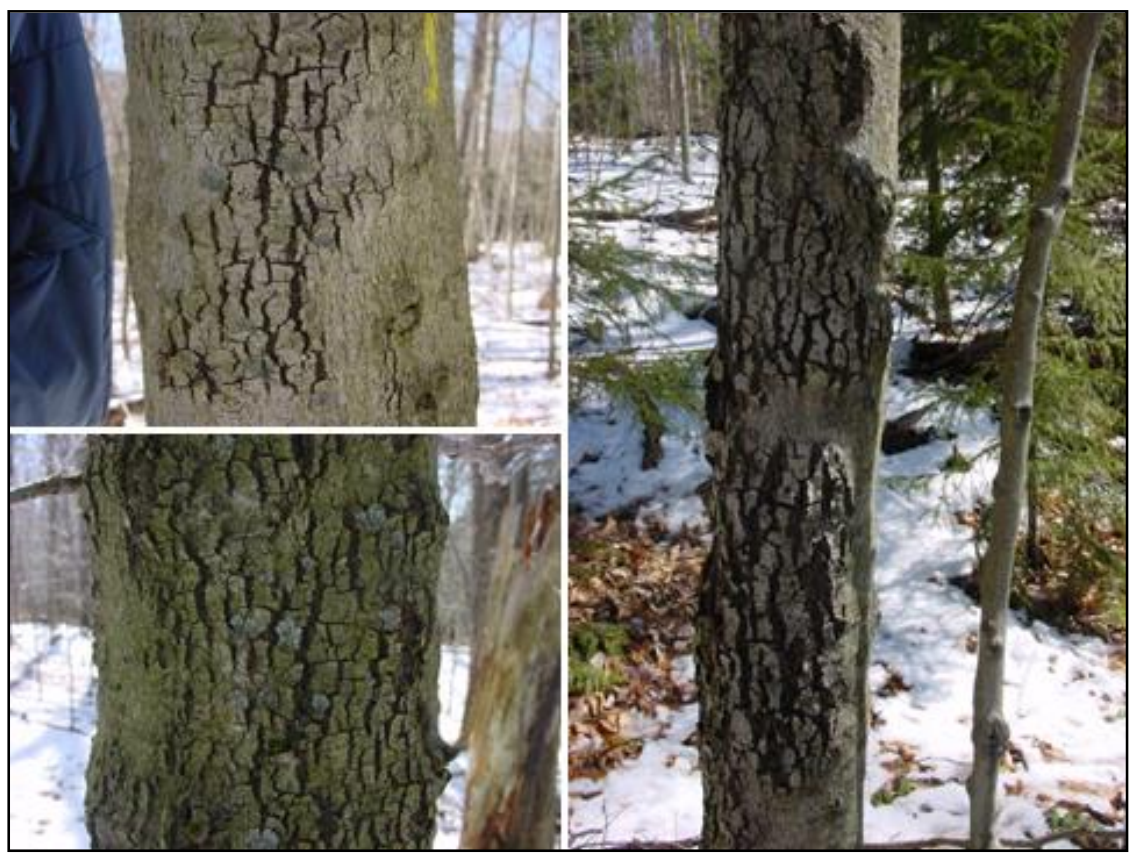

Figure 29: Blocky cankers observed on Fagus grandifolia in Randolph County, WV. 


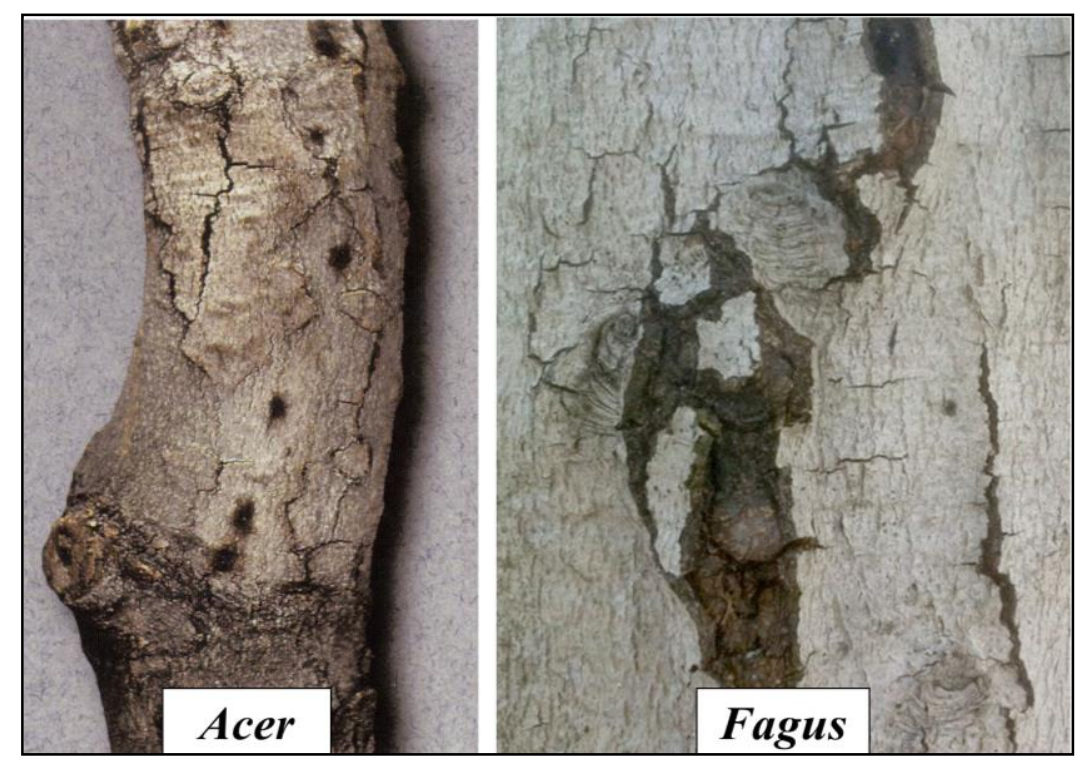

Figure 30: Fusarium canker on Acer sp. (Image from Sinclair and Lyon, 2005) and blocky canker on Fagus grandifolia in Randolph County, WV.

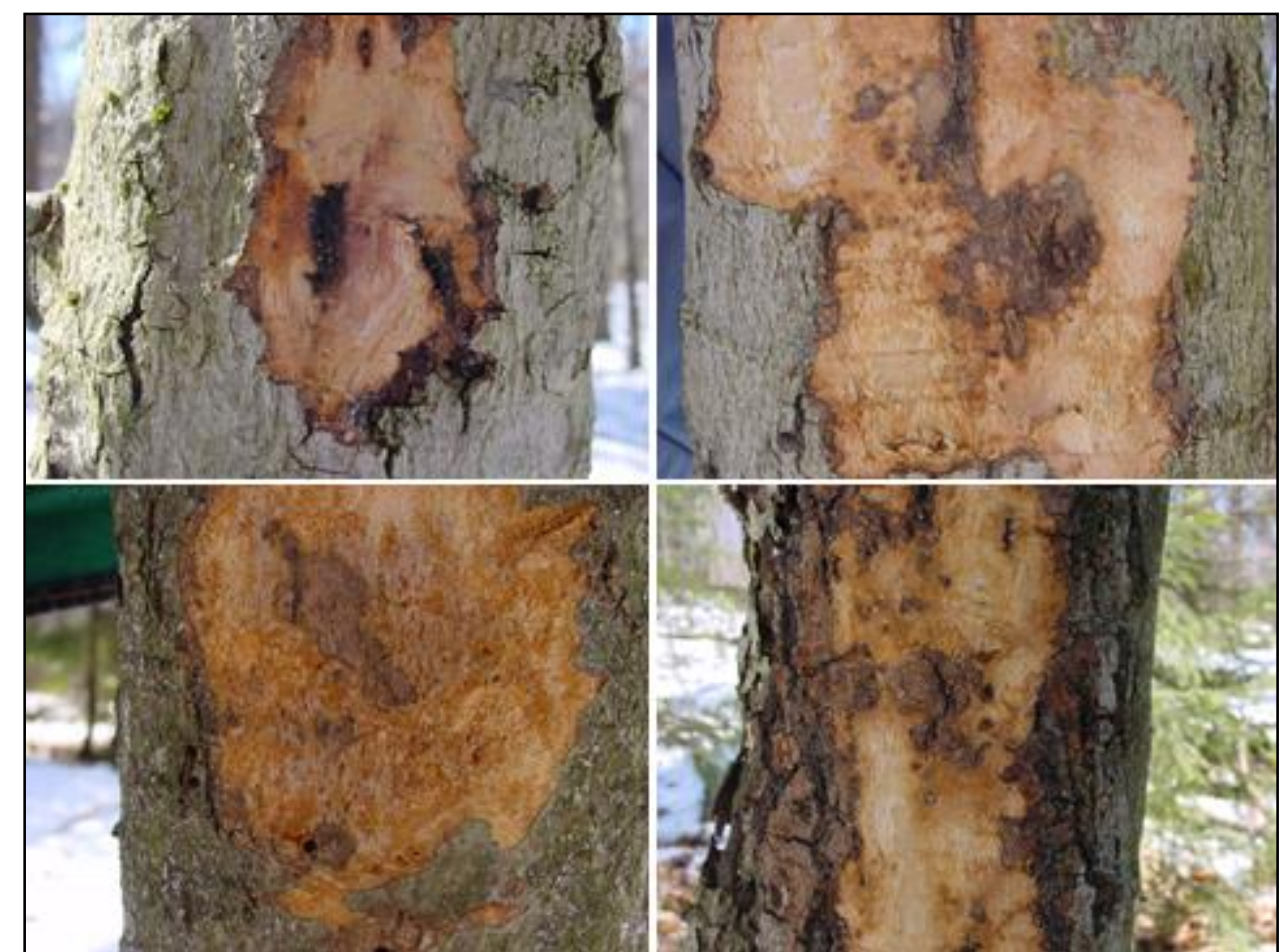

Figure 31: Discolored tissues under blocky cankers on Fagus grandifolia in Randolph County, WV. 


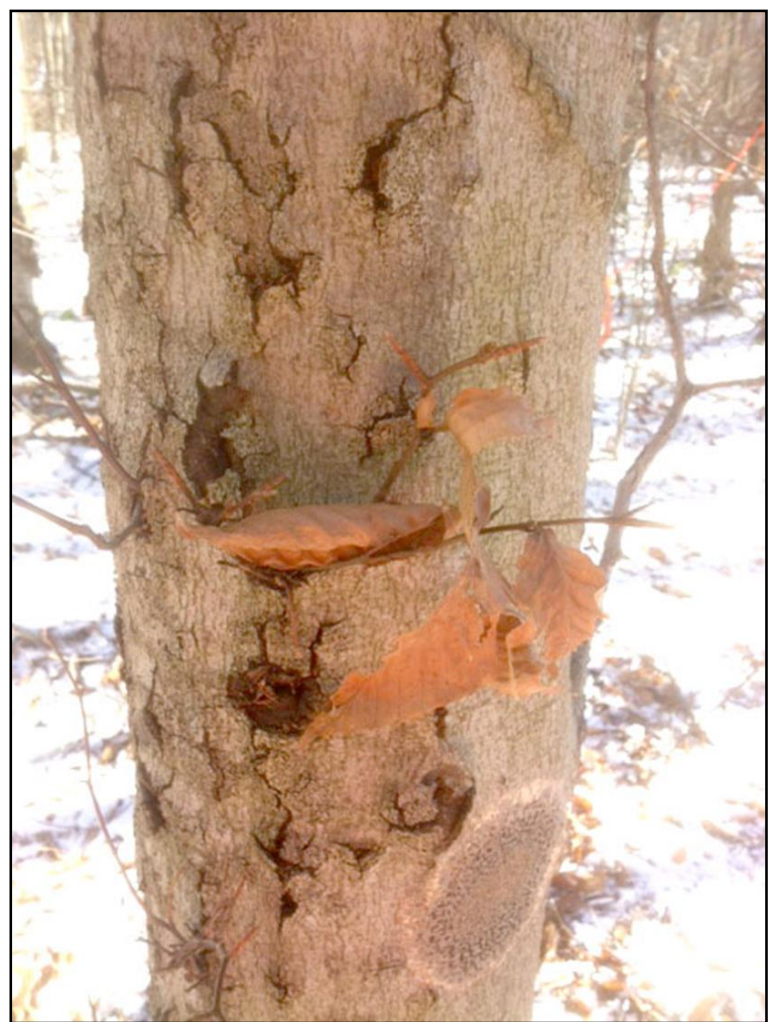

Figure 32: Epicormic sprouts growing from blocky cankers on Fagus grandifolia in Tucker County, WV.

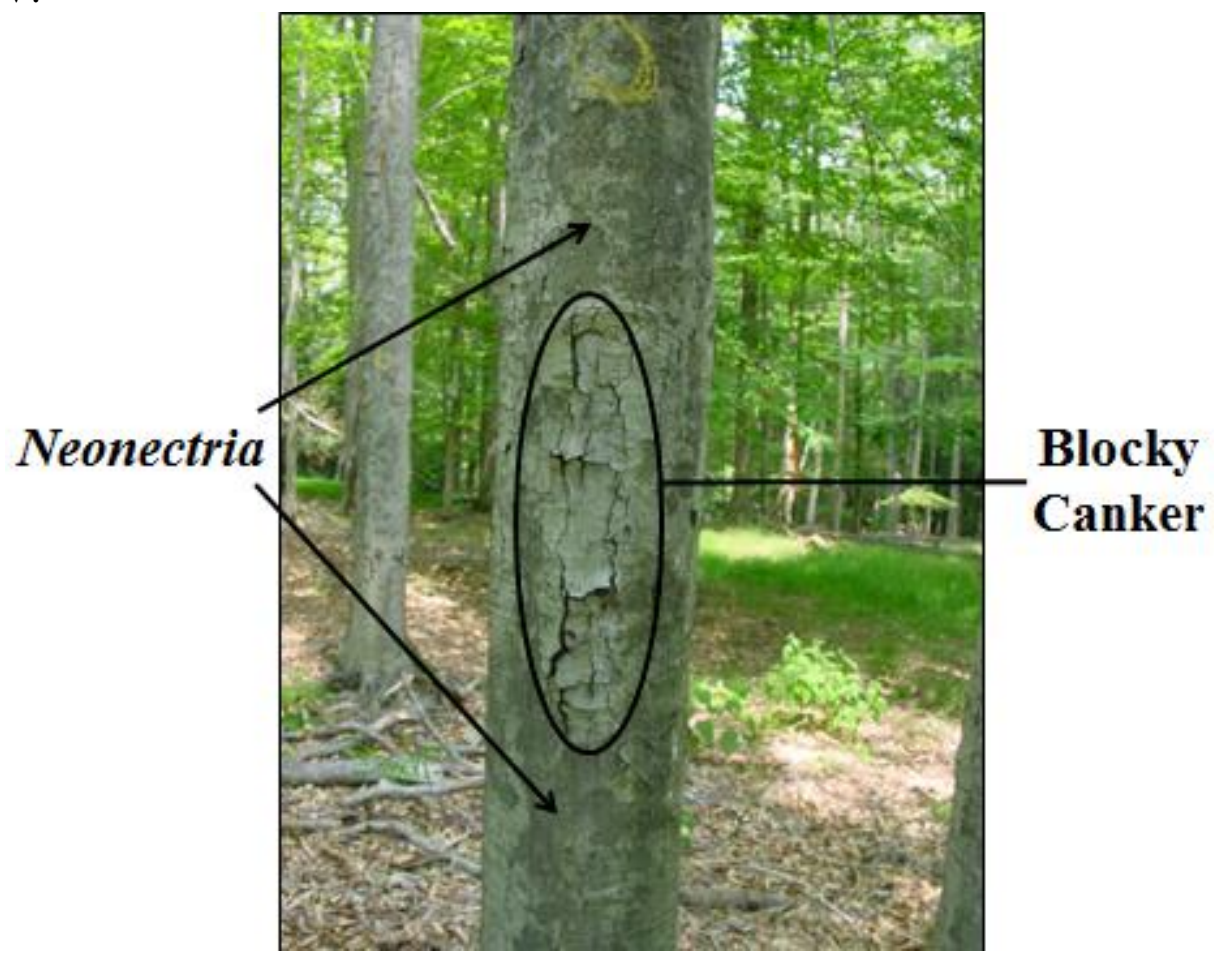

Figure 33: Blocky canker on Fagus grandifolia in Tucker County, WV. Neonectria fruiting is not evident in the encircled blocky area. 


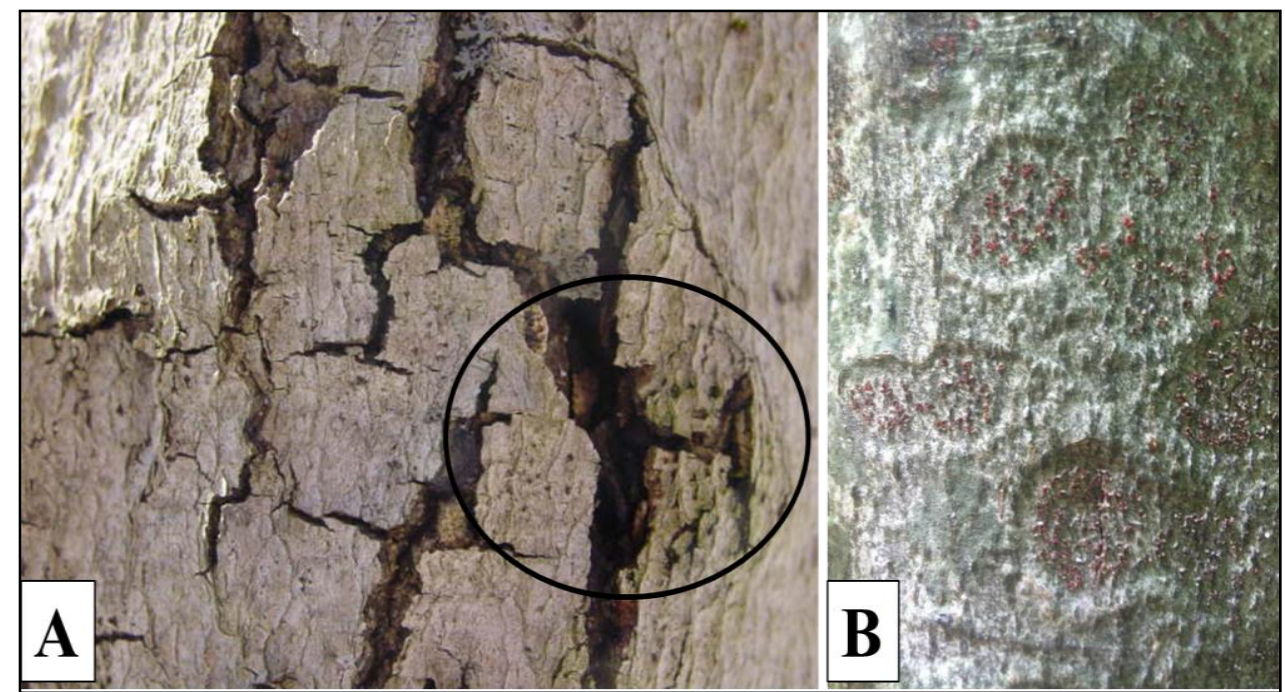

Figure 34: Blocky canker on Fagus grandifolia with dead Neonectria perithecia (A) and Neonectria cankers with viable perithecia (B) in Randolph County, WV.

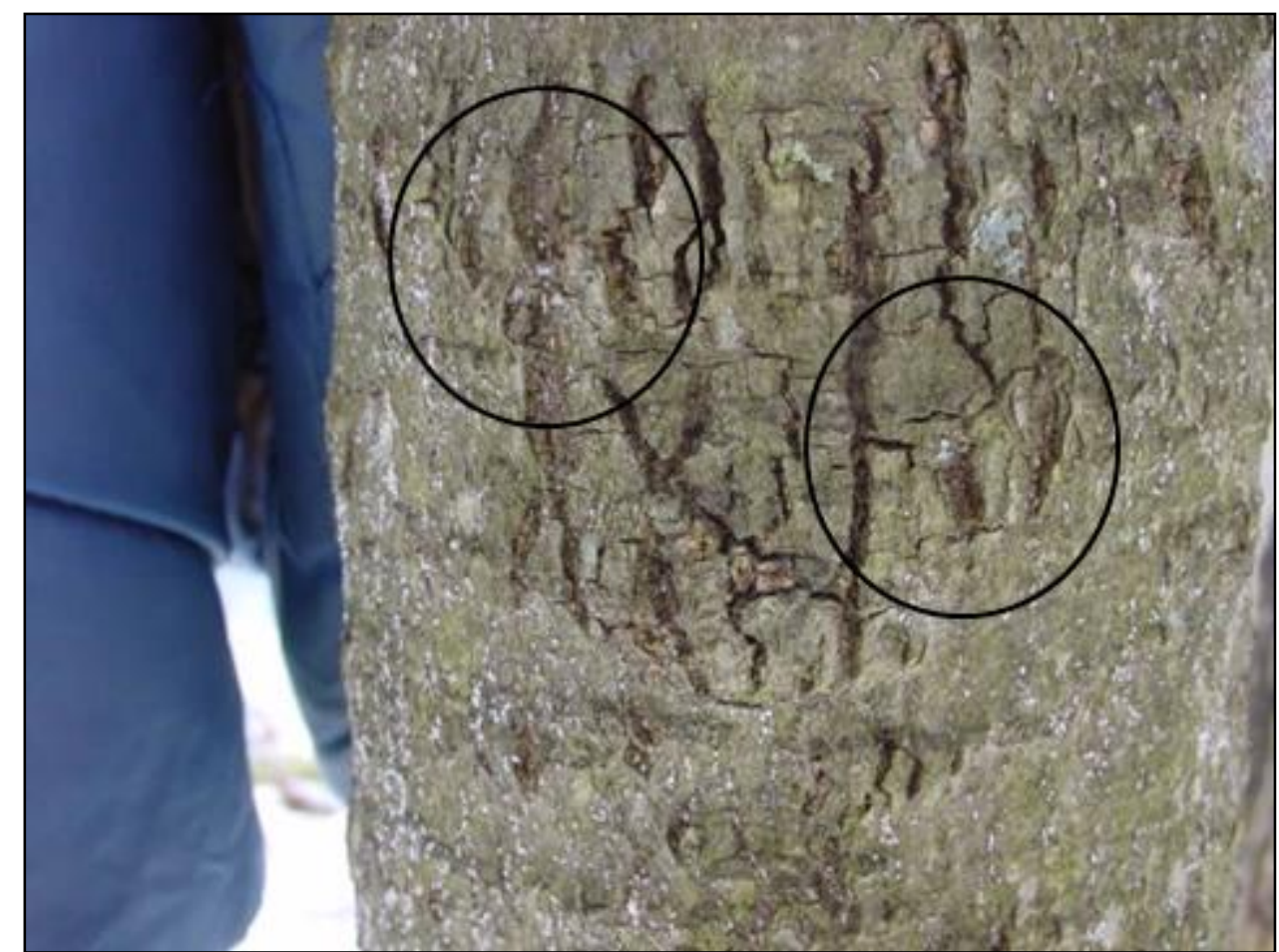

Figure 35: Blocky canker with Cryptococcus on Fagus grandifolia in Randolph County, WV.

\section{Hypothesis and Objectives}

This investigation is based on the hypothesis that blocky cankers observed on American beech are caused by a bark pathogen that may inhibit or compete with Neonectria fungi. The experiment attempted to identify fungi associated with unusual blocky cankers on American beech. Specific objectives are to:

1. Sample blocky cankers to isolate and identify fungi, if any, regularly associated them; 
2. Evaluate the relationships, if any, of fungi isolated from blocky cankers on Neonectria fungi, and;

3. Conduct field inoculations of American beech with fungi isolated from blocky canker fungi and Neonectria fungi and evaluate the effects on beech bark

\section{Methodology}

\section{Fungal Identification}

A total of 1,565 3mm bark plugs were collected at seven sites in Pennsylvania, West Virginia, and Tennessee (Table 14). In total, 403 blocky cankers and 140 beech stems were sampled. Plugs were cultured on potato dextrose agar (PDA) to isolate fungi. Cultural and morphological characteristics were used for identification. To confirm morphological identification, the ITS of the rRNA-encoding region of a representative fungal sample obtained from blocky cankers was amplified with PCR. Amplified DNA products were shipped to Davis Sequencing in Davis, CA for sequencing.

Table 14: Study sites in the Appalachian region where blocky cankers on Fagus grandifolia were sampled.

\begin{tabular}{lcc}
\hline \multicolumn{1}{c}{ Location } & $\begin{array}{c}\text { Cankers } \\
\text { Sampled }\end{array}$ & $\begin{array}{c}\text { Stems } \\
\text { Sampled }\end{array}$ \\
\hline Allegheny National Forest, PA & 45 & 15 \\
Blackwater Falls State Park, WV I & 68 & 23 \\
Blackwater Falls State Park, WV III & 45 & 15 \\
Gaudineer Scenic Area, Monongahela National Forest, WV & 85 & 29 \\
Great Smoky Mountains National Park, TN & 18 & 8 \\
Kumbrabow State Forest, WV & 70 & 26 \\
Middle Mountain, Monongahela National Forest, WV & 72 & 24 \\
\hline
\end{tabular}

\section{Fungal Growth and Competition}

Single spore isolates of selected fungi and Neonectria fungi were cultured on PDA (10 replicates) individually to compare growth rates. They also were paired in petri dishes (10 replicates) on PDA to observe growth rates when competing and how they interact. Observations were recorded after 7 and 14 days.

\section{$\underline{\text { Nucleotide/Statistical Analyses }}$}

Sequencing results were evaluated with a nucleotide blast in the BLAST program at the National Center for Biotechnology Information (NCBI) website (http://blast.ncbi.nlm.nih.gov/Blast.cgi). Mean diameters of colonies at 7 days and 14 days were obtained by measuring the length (mm) of ten colonies along two perpendicular axes. Differences in colony size of individual and competing isolates were evaluated with Student's t-test. 


\section{Results}

\section{$\underline{\text { Fungal Identification }}$}

A total of 403 cankers were sampled. Fusarium species were recovered from 344 (85\%) of sampled cankers (Figure 36). One hundred forty beech stems were sampled, Fusarium species were recovered from 133 (95\%) (Figure 37). Phomopsis species were the next most commonly isolated fungi but only from $20 \%$ of cankers and $37 \%$ of stems.

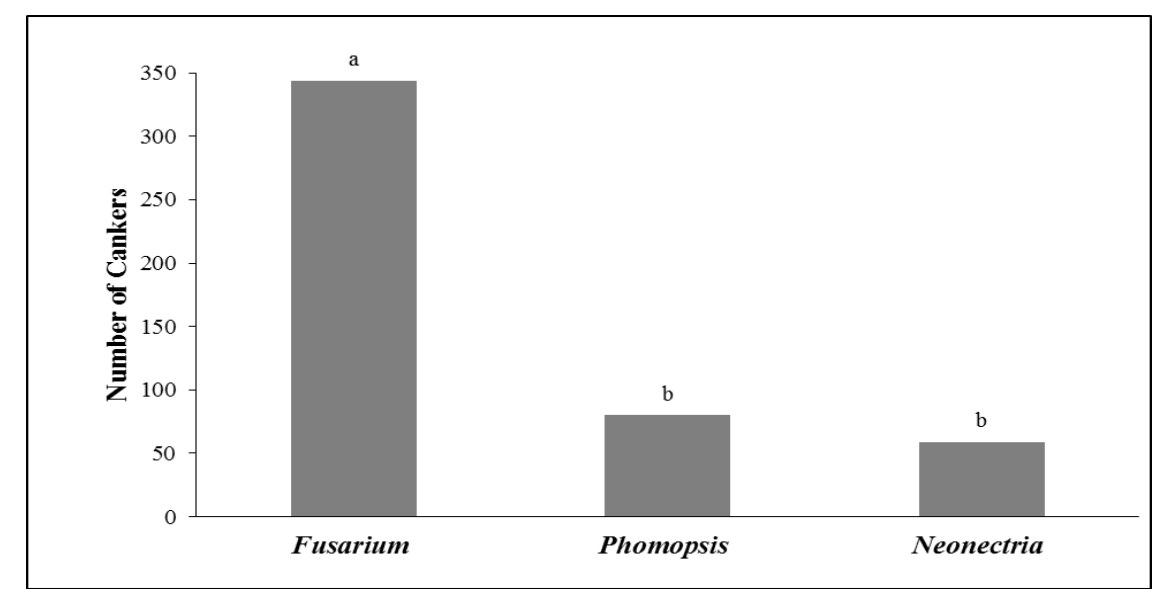

Figure 36: Total number of blocky beech cankers sampled at seven sites in the Appalachian region from which Fusarium, Phomopsis, or Neonectria spp. were isolated; total cankers sampled $=403$. Statistically more cankers had Fusarium than Phomopsis or Neonectria $(\mathrm{p}<$ $0.005)$.

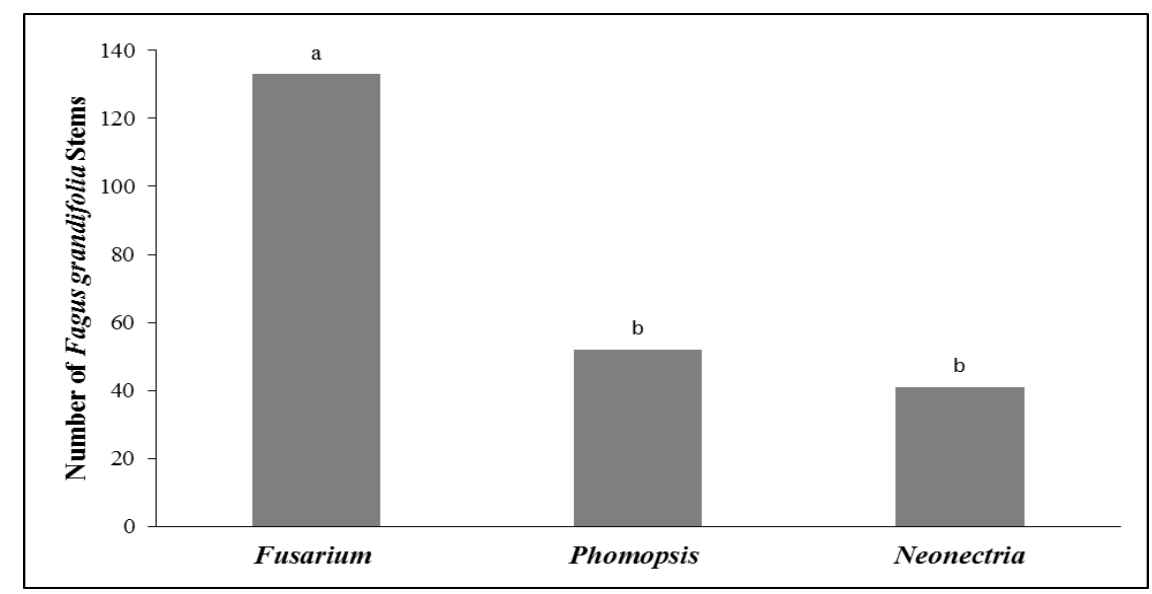

Figure 37: Total number of Fagus grandifolia stems sampled at seven sites in the Appalachian region from which Fusarium, Phomopsis, or Neonectria spp. were isolated; total beech sampled = 140; Statistically more Fagus grandifolia stems had Fusarium than Phomopsis or Neonectria $(\mathrm{p}<0.005)$.

An NCBI nucleotide blast of a representative fungal sample indicated Fusarium tricinctum was commonly isolated from blocky cankers on American beech (Appendix 5, Table 3). A 502 nucleotide sequence of ITS (97\% of the submitted sequence) had 100\% alignment with a known 
F. tricinctum isolate (Fusarium tricinctum isolate HLJ_11 internal transcribed spacer 1, partial sequence; 5.8S ribosomal RNA gene and internal transcribed spacer 2, complete sequence; and 28S ribosomal RNA gene, partial sequence; Sequence ID: gb|JN088234.1|Length: 518). An NCBI nucleotide blast E-value of 0.0 suggests little alignment due to chance and homology between the two sequences. Fusarium tricinctum designates a complex of three species, $F$. poae $F$. chlamydosporum, and $F$. sporotrichioides, each of which has distinct morphological characteristics (Figure 38; Nelson et al., 1983). These varied characteristics also were evident in Fusarium tricinctum isolates obtained from blocky cankers (Figure 39).

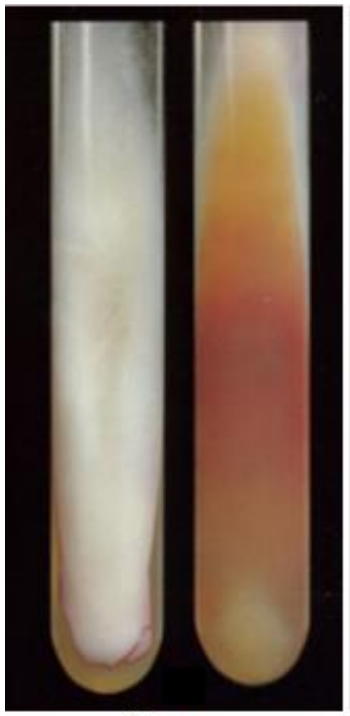

F. poae

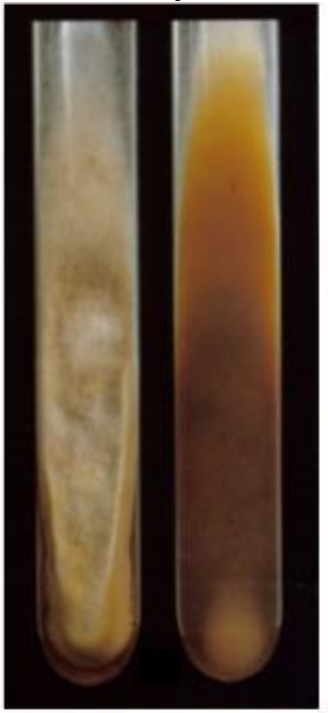

F. chlamydosporum

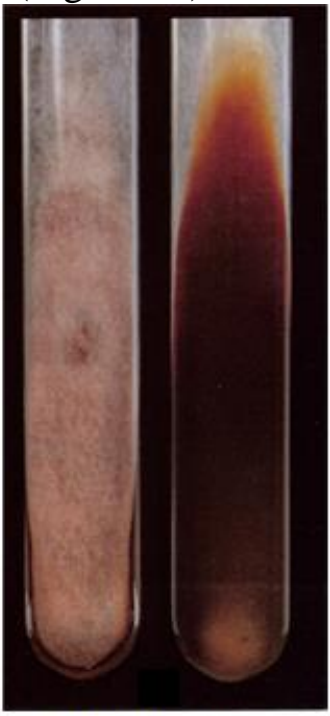

F. sporotrichioides

Figure 38: Fusarium species in the Fusarium tricinctum complex (Images from Nelson et al., 1983).
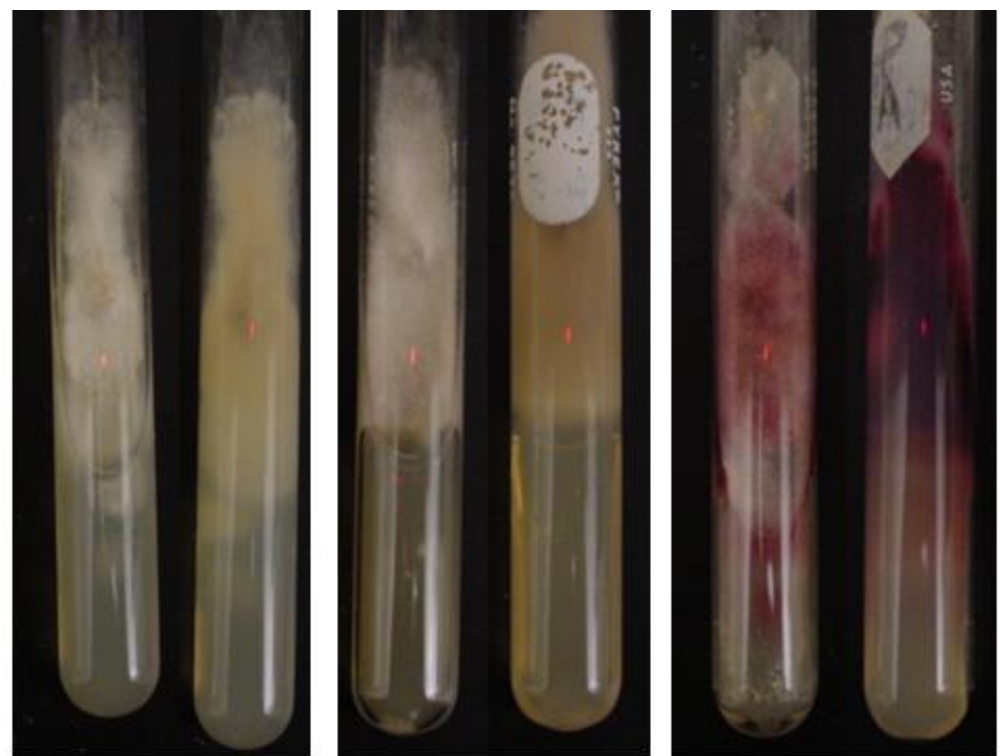

Figure 39: Fusarium species isolated from blocky cankers on Fagus grandifolia in the Appalachian region. 


\section{Fungal Growth and Competition}

When grown individually or paired, for 7 and 14 days, Fusarium colonies were statistically larger than Neonectria colonies (Figures 40-42; $\mathrm{p}<0.005$ ). Neonectria colonies competing with Fusarium were statistically smaller than individually grown colonies after 7 days $(\mathrm{p}=0.008)$ and 14 days (Figure 43; $p<0.001$ ). There was no evidence of hyphal connections that could indicate direct contact between Fusarium and Neonectria colonies when grown together (Figure 44).

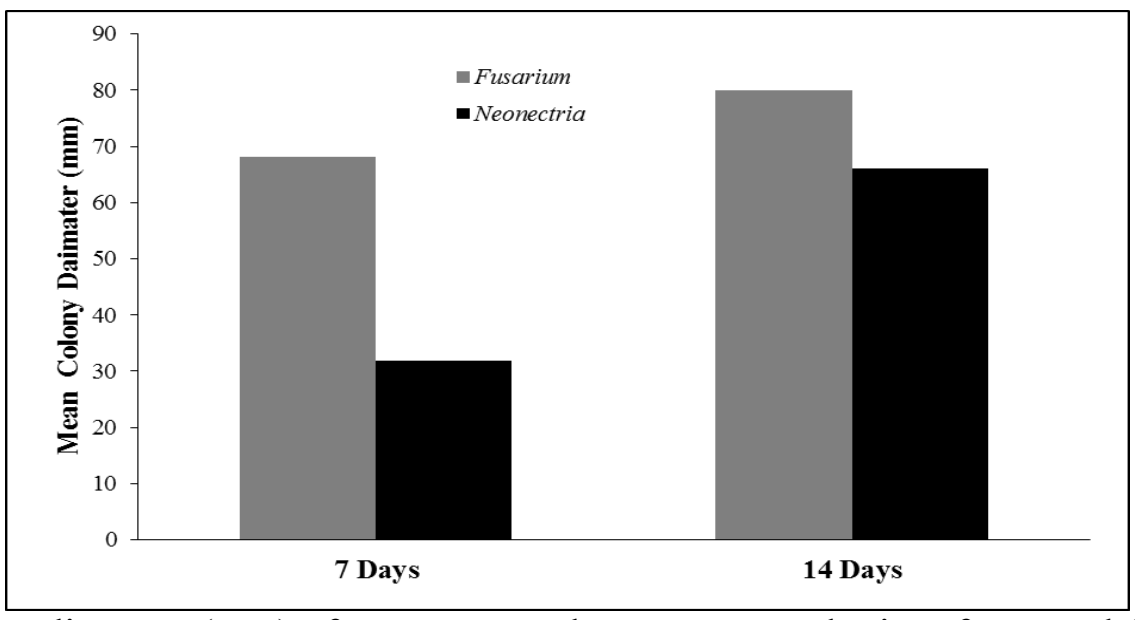

Figure 40: Mean diameter (mm) of Fusarium and Neonectria colonies after 7 and 14 days on PDA $(n=10)$. Means were calculated from measurements of two perpendicular axes on each of ten colonies. Fusarium colonies were statistically larger than Neonectria colonies after 7 and 14 days $(\mathrm{p}<0.005)$.

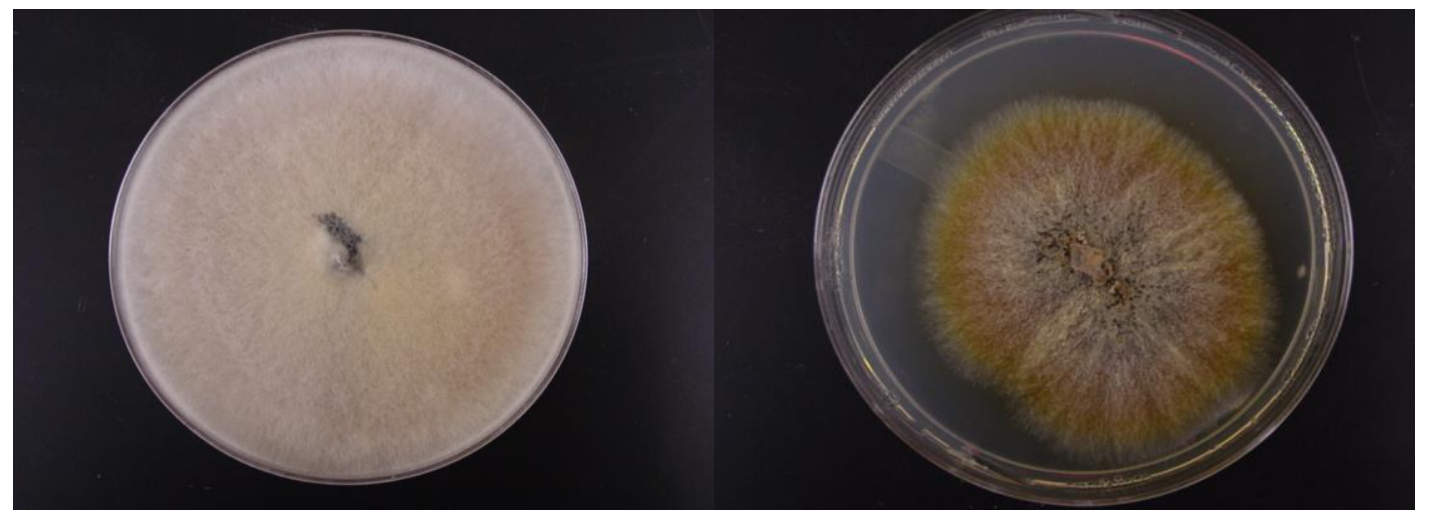

Figure 41: Individual Fusarium colony (left) and Neonectria colony (right) after 14 days. 


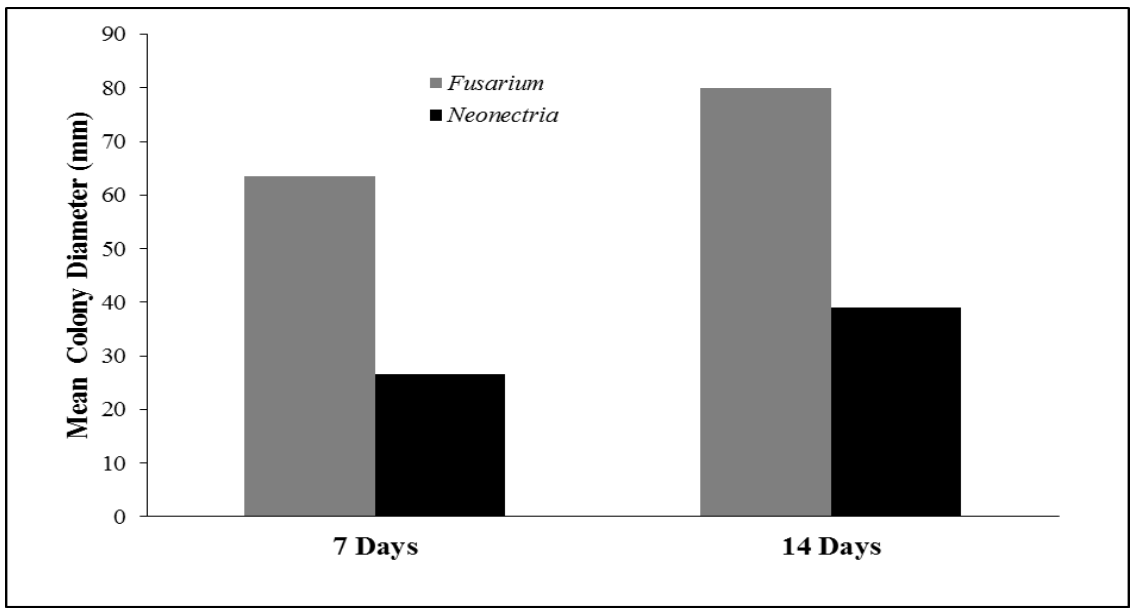

Figure 42: Mean diameter (mm) of paired Fusarium and Neonectria colonies after 7 and 14 days on PDA $(n=10)$. Means were calculated from measurements of two perpendicular axes on each of ten colonies. Fusarium colonies were statistically larger than Neonectria colonies after 7 and 14 days $(\mathrm{p}<0.005)$.

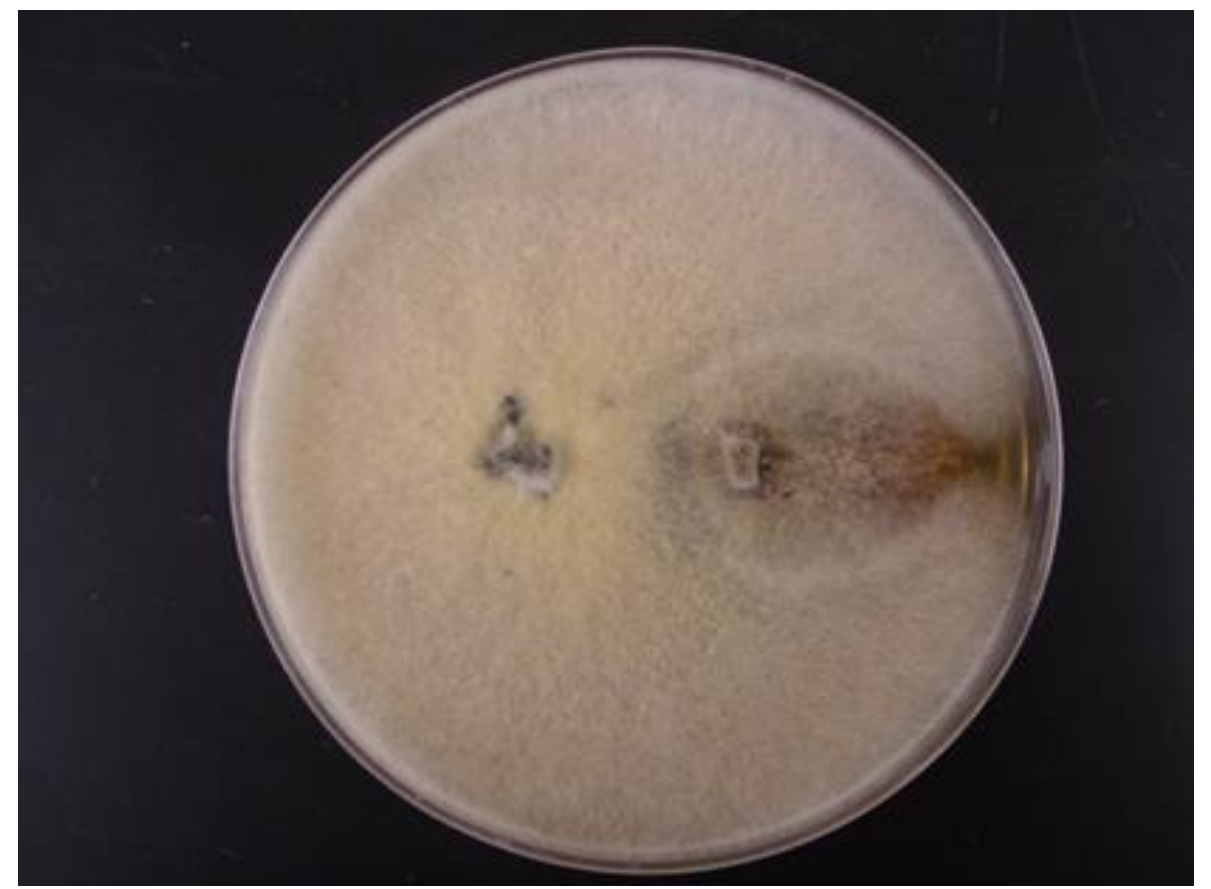

Figure 43: Paired Fusarium (left side of plate) and Neonectria (right side of plate) isolates after 14 days. The Neonectria colony is overgrown by the Fusarium colony and statistically smaller than Neonectria colonies grown without Fusarium (p < 0.001). 


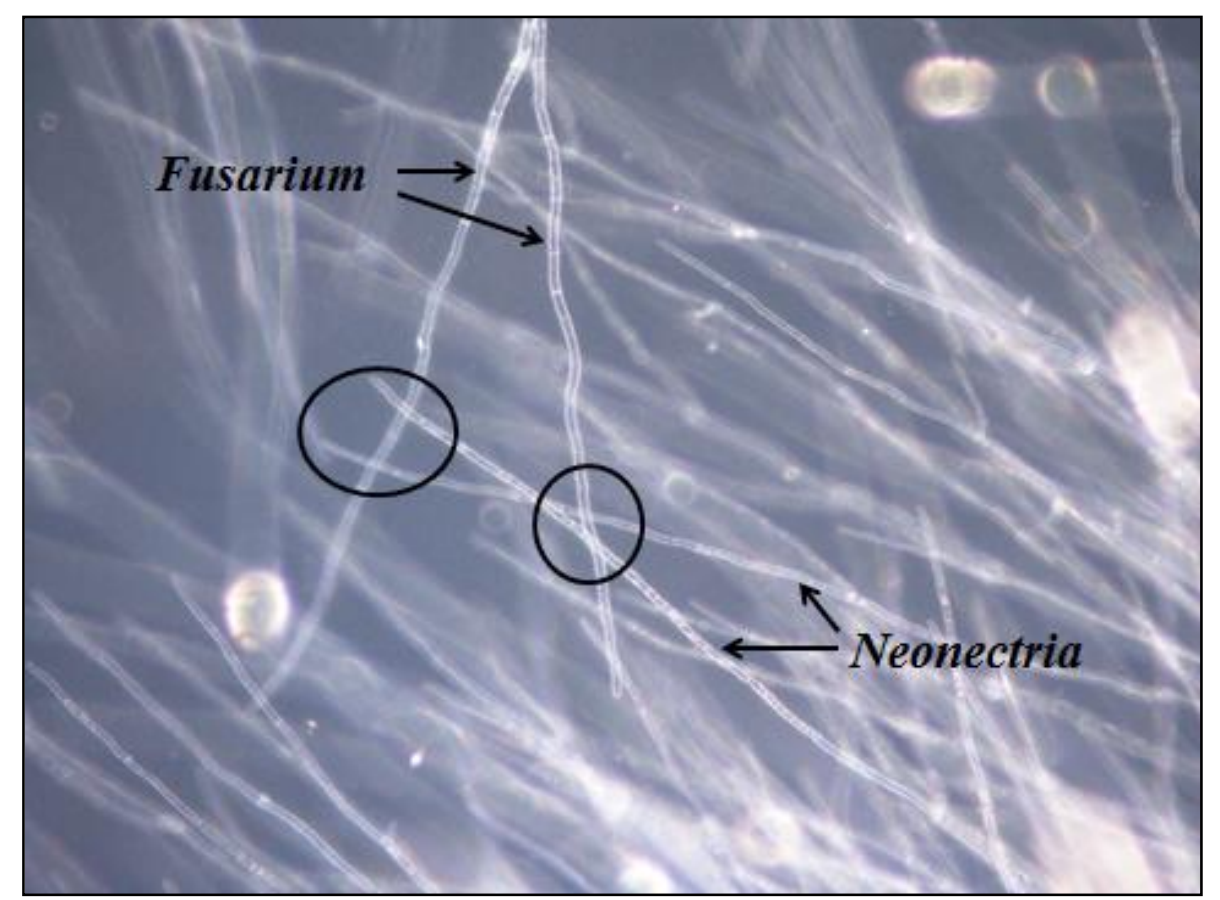

Figure 44: Light microscope image of Fusarium fungus and Neonectria faginata growing together in the same medium. There are no connections between the adjacent hyphae of each fungus that would indicate physical interaction.

\section{Discussion}

The results of this investigation indicate Fusarium tricinctum is predominant in the unusual blocky cankers. The spread of $F$. tricinctum in beech bark may produce distinct blocky cankers that influence the spread of Neonectria fungi associated with BBD. Fusarium fungi covered entire plates after 14 days in all replicates. Pairing with Neonectria did not reduce Fusarium growth, but Neonectria colonies were smaller when grown with Fusarium. Microscopic examination of mingled hyphae did not reveal hyphal connections between the fungi in culture, but there could be chemical interactions. Based on the growth of colonies in culture, competition by Fusarium fungi in bark of American beech may limit Neonectria infection. Fusarium fungi were routinely isolated from bark samples of blocky cankers. Analyses of ecological factors indicate blocky cankers are significant for and positively correlated with infestation but negatively correlated with infection. Observations in the field and laboratory suggest blocky cankers did not inhibit scale establishment, but did inhibit Neonectria fungi. Fusarium fungi may generate blocky cankers that are relatively innocuous for beech but exclude Neonectria. Wounds inflicted by beech scale may be colonized by Fusarium fungi before Neonectria fungi can enter. Conversely, Neonectria fungi may enter bark wounds first but be quickly overgrown and limited by Fusarium fungi that follow. Furthermore, Fusarium fungi may be latent on beech bark and actively form blocky cankers when triggered by host stress, including scale infestation.

Positive correlation between infestation and beech with another bark fungus $A$. rugosa suggests scale establishment is favored by A. rugosa. Houston et al. (1979a) found scale populations were reduced on European beech with A. rugosa. Studies of the effects of A. rugosa on tree bark by Butin and Parameswaran (1980) found the fungus encourages thickened periderm. However, 
Speer and Butin (1980) found scale stylets can still penetrate thickened periderm when secondary periderm is not formed. Furthermore, growth of A. rugosa on American beech differs from its growth on European beech in that stroma is often thinner and less compact offering a favorable habitat for scale (Houston, 2005).

Negative correlation between beech with A. rugosa and Neonectria infection suggests Neonectria is limited by the presence of A. rugosa. Seemingly the effects of A. rugosa on scale may be mixed. The effect of $A$. rugosa on infection in this study may be a function of the dependence of Neonectria on scale or an exclusion of Neonectria by A. rugosa similar to the apparent exclusion by Fusarium fungi reported here.

\section{Conclusions}

Analyses of ecological factors suggest scale infestation is positively, but Neonectria infection is negatively, correlated with $A$. rugosa and blocky cankers. Blocky cankers seem to be innocuous to beech and not problematic for the cambium. Whereas A. rugosa and blocky cankers with an apparent association with Fusarium fungi seemingly include scale they may exclude Neonectria. If Neonectria infection excludes scale establishment as reported, but Fusarium does not, then the observed positive correlations with infestation make sense: A. rugosa or Fusarium infections excluding Neonectria may enable more infestation. The A. rugosa and blocky canker phenomena are curious and detailed investigations may illuminate how, if at all, A. rugosa and Fusarium fungi affect the beech bark disease complex. 


\section{$\underline{\text { Literature Cited }}$}

Adams, M.B.; Angradi, T.R. 1996. Decomposition and nutrient dynamics of hardwood leaf litter in the Fernow whole-watershed acidification experiment. Forest Ecology and Management 83: 61-69.

Alavo, T.B.C; Accodji, M. 2004. The entomopathogenic fungus Verticillium lecanii (Deuteromycetes, Moniliaceae). The proteins hydrophobins and the biological control of aphids (Homoptera, Aphididae): literature review. Archives of Phytopathology and Plant Protection. 37: 201-204.

Alexopoulos, C.J.; Mims, C.W.; Blackwell, M.M. 1996. Introductory Mycology, $4^{\text {th }}$ ed. John Wiley and Sons, New York, NY.

American Forestry Association. 1951. Report on American big trees, Part I. American Forests 57: 25-26.

Barter, G. W. 1953. Additional observations on the beech scale in New Brunswick. Bi-Monthly Progress Report, Division of Forest Biology, Canada Department of Agriculture 9: 1-2.

Berry, E.W. 1916. Notes on the ancestry of beech. Plant World 19: 68-77.

Blair, J.M. 1988. Nitrogen, sulfur and phosphorus dynamics in decomposing deciduous leaf litter in the southern Appalachians. Soil Biology and Biochemistry 20: 693-701.

Bonello, P; Gordon, T.R; Herms, D.A; Wood, D.L.; Erbilgin, N. 2006. Nature and ecological implications of pathogen-induced systemic resistance in conifers: a novel hypothesis. Physiological and Molecular Plant Pathology 68:95-104.

Brayford, D.; Honda, B.M.; Mantiri, F.R. 2004. Neonectria and Cylindrocarpon: the Nectria mammoidea group and species lacking microconidia. Mycologia 96: 572-597.

Brower, A.E. 1949. The Beech Bark Disease in Acadia National Park. Journal of Economic Entomology 42(2): 226-228.

Brown, H.P. 1922. Trees of New York State, native and naturalized. New York State University College of Forestry Technical publication 15. 401p.

Brown, M.K.; Will, G. 1979. Food habits of the fisher in northern New York. New York Fish and Game Journal 26:87-92.

Burns, R.M., tech. comp. 1983. Silvicultural systems for the major forest types of the United States. Agricultural Handbook 445. USDA Forest Service, Washington D.C. 191p.

Burns, B.S.; Houston, D.R. 1987. Managing beech bark disease: evaluating defects and reducing losses. Northern Journal of Applied Forestry 4: 28-33. 
Butin, H.; Parameswaran, N. 1980. Ultrastructure of Aschodichaena rugosa on beech bark. Archives of Microbiology 126: 87-95.

Cale, J.A; Letkowski, S.K.; Teale, S.A.; Castello, J.D. 2012. Beech bark disease: an evaluation of the predisposition hypothesis in an aftermath forest. Forest Pathology 42: 52-56.

Cale, J.A; Ashby, A.W.; West, J.L.; Teale, S.A.; Johnston, M.T.; Castello, J.D. 2015. Scale insects, decay and canker fungi in American beech. Forest Pathology 45: 71-75.

Camp, W.H. 1950. A biogeographic and paragentic analysis of the American Beech (Fagus). American Philosophical Society Yearbook, 1950: 166-169.

Camp, W.H. 1951. A study of the relative virulence of beech bark disease on the several types of forest beech present in eastern Canada and Maine. American Philosophical Society Yearbook, 1951: 180-183.

Carpenter, R.D. 1974. American Beech. American woods. USDA Forest Service FS-220. Washington, D.C. 8p.

Castlebury, L.A.; Rossman, A.Y.; Hyten, A.S. 2006. Phylogenetic relationships of Neonectria/Cylindrocarpon on Fagus in North America. Canadian Journal of Botany 84: 14171433.

Cotter, H.V.T. 1977. Beech bark disease; fungi and other associated organisms. MS thesis. University of New Hampshire, Durham. 142 p.

Cotter, H.V.T.; Blanchard, R.O. 1981. Identification of the two Nectria taxa causing bole cankers of American beech. Plant Disease. 65: 332-334.

Cotter, H.V.T.; Blanchard, R.O. 1982. The fungal flora of bark of Fagus grandifolia. Mycologia 74: 836-843.

Crosby, D.; Bjorkbom, J.C. 1958. Timley salvage can reduce losses from beech scale-nectria attack. USDA Forest Service Northeast Forest Experiment Station Research Note 82. Newton Square, PA. 4p.

Dadd, R.H.; Mittler, T.E. 1965. Studies on artificial feeding of the aphid Myzus persicae (Sulzer). III. Some major nutritional requirements. Journal of insect Physiology 11: 717-743.

Davis, P.M. 1994. Statistics for describing populations. In: Pedigo, L.P. and Buntin, G.D. eds., Handbook of Sampling Methds for Arthropods in Agriculture p. 33-54. CRC Press, Boca Raton, FL.

Edmunds, G.F.; Alstad, D.N. 1978. Coevolution in insect herbivores and conifers. Science. 199: 941- 945. 
Ehrlich, J. 1934 The beech bark disease, a Nectria disease of Fagus, following Cryptococcus fagi (Baer.). Canadian Journal of Forest Research 10: 593-692.

Eyles, A.; Bonello, P.; Ganley, R.; Mohammed, C. 2010. Induced resistance to pests and pathogens in trees. New Phytologist 185: 893-908.

Fang, J.; Lechowicz, M.J. 2006. Climatic limits for the present distribution of beech (Fagus L.) species in the world. Journal of Biogeography 33: 1804-1819.

Felt. E.P. 1933. The beech scale and a fungus. Journal of Economic Entomology 26: 510.

Filip, S.M. 1978. Impact of beech bark disease on uneven-age management of a northern hardwood forest (1952-1976). USDA Forest Service Genera Technical Report NE-45. Newton Square, PA. $7 p$.

Flowers, R.W.; Salom, S.M.; Kok, L.T. Competitive interactions among two specialist predators and a general predator of hemlock woolly adelgid, Adelges tsugae (Homoptera: Adelgidae), in the laboratory. Environmental Entomology 34: 664-675.

Forcier, L.K. 1975. Reproductive strategies and cooccurrence of climax species. Science 189: 808-810.

Forrester, J.A.; McGee, G.G.; Mitchell, M.J. 2003. Effects of beech bark disease on aboveground biomass and species composition in a mture northern hardwood forest, 1985 to 2000. Journal of the Torrey Botanical Society 130: 70-78.

Gain, R.E.; H.L. Barnett. 1970. Parasitism and axenic growth of the mycoparasite Gonatorhodiella highlei. Mycologia 62: 1122-1129.

Galway, K.E.; Duncan, E.P.; Syrett, P.; Emberson, R.M.; Sheppard, A.W. 2004. Insect performance and host-plant stress: a review from a biological control perspective In: Cullen, J.M.; Briese, D.T.; Kriticos, D.J.; Lonsdale, W.M.; Morin, L.; and Scott, J.K. eds., 2004. Proceedings of the XI International Symposium on Biological Control of Weeds. CSIRO Entomology, Canberra, Australia, 648 pp.

Gate, I.M. 1988. Population ecology of the beech scale (Cryptococcus fagisuga Lindinger). Doctoral Thesis, University of London.

Gavin, D.G.; Peart, D.R. 1993. Effects of beech bark disease on the growth of American beech (Fagus grandifolia). Canadian Journal of Forest Research 23: 1566-1575.

Garnas, J. 2009. Organism interactions and forest structural change in a nonnative disease complex: beech bark disease in North America. PhD Thesis, Dartmouth College, Hanover, NH.

Garnas, J.; Houston, D.R.; Ayres, M.P.; Evans, C. 2012. Disease ontogeny overshadows effects of climate and species interactions on population dynamics in a nonnative forest disease complex. Ecography 35: 412-421. 
Garnas, J.; Houston, D.R.; Twery, M.J.; Ayres, M.P.; Evans, C. 2013. Inferring controls on the epidemiology of bech bark disease from spatial patterning of disease organisms. Agricultural and Forest Entomology 15: 146-156.

Gosz, J.R.; Likens, G.E.; Bormann, F.H., 1973. Nutrient release from decomposing leaf and branch litter in the Hubbard Brook Forest, New Hampshire. Ecological Monographs 43: 173191.

Gove, J.H.; Houston, D.R. 1996. Monitoring the growth of American beech affcetd by beech bark disease in Maine using the Kalman filter. Environmental and Ecological Statistics 3: 167187.

Griffin, J.M.; Lovett, G.M.; Arthur, M.A.; Weathers, K.C. 2003. The distribution and severity of beech bark disease in the Catskill Mountains, N.Y. Canadian Journal of Forest Research 33: 1754-1760.

Gwiazdowski, R.A.; Van Driesche, R.G.; Desnoyers, A.; Lyon, S.; Wu, S. 2006. Possible geographic origin of beech scale, Cryptococcus fagisuga (Hemiptera: Eriococcidae), an invasive pest in North America. Biological Control 39: 9-18.

Halls, Lowell K. 1977. American beech/Fagus grandifolia Ehrh. In: Southern fruit-producing woody plants used by wildlife. USDA Forest Service, General Technical Report SO-16. Southern Forest: 147-148.

Hamilton, L.S. 1955. Silvicultural characteristics of American Beech. USDA Forest Service, Northeastern Forest Experiment Station Beech Utilization Series No. 13. 39p.

Harlow, W.M.; Harrar, E.S.; White, F.M., eds. 1979. Textbook of Dendrology. McGraw-Hill Book Company, San Francisco, CA.

Heyd, H.L. 2005.Managing beech bark disease in Michigan. In: Evans, C.; Lucas, J.A.; Twery, M.J., eds. Beech bark disease: proceedings of the beech bark disease symposium, 2004, Saranac Lake, NY. Gen. Tech. Rep. NE-331. Newton Square, PA: USDA Forest Service, Northeastern Research Station: 128-132.

Hirooka, Y.; Kobayashi, T. 2007. taxonomic studies of nectrioid fungi in Japan. I: The genus Neonectria. Mycoscience. 48: 53-62.

Holmes, R.T.; Schultz, J.C. 1988. Food availability of forest birds; effects of prey distribution and an abundance on bird foraging. Canadian Journal of Zoology 66: 720-728.

Holling, C.S. 1973. Resilience and stability of ecological systems. Annual Review of Ecology and Systematics 4:1-23.

Horikawa, Y. 1972. Atlas of the Japanese flora: an introduction to the plant sociology of East Asia. Gakken Co. Ltd, Tokyo. 
Houston, D.R. 1975. Beech bark disease, the aftermath forests are structured for a new outbreak. Journal of Forestry. 73: 660-663.

Houston, D.R. 1982. A technique to artificially infest beech bark with the beech scale, Cryptococcus fagisuga (Lindinger). Res. Pap. NE-507. Broomall, PA: USDA Forest Service, Northeastern Forest Experiment Station. 8 p.

Houston, D.R. 1983. American beech resistance to Cryptococcus fagisuga. In: Proceedings of the IUFRO beech bark disease working party conference; 1982 September 26-October 8; Hamden, CT. Gen. Tech. Rep. WO-37. Washington, DC: USDA Forest Service: 38-42.

Houston, D.R. 1994a. Major new tree disease epidemics: beech bark disease. Annual Review of Phytopathology. 32: 75-87.

Houston, D.R. 1994b. Temporal and spatial shift within the Nectria pathogen complex associated with beech bark disease of Fagus grandifolia. Canadian Journal of Forest Research. 24: 960-968.

Houston, D.R. 2005. Beech bark disease: 1934-2004: what's new since Ehrlich? In: Evans, C.; Lucas, J.A.; Twery, M.J., eds. Beech bark disease: proceedings of the beech bark disease symposium, 2004, Saranac Lake, NY. Gen. Tech. Rep. NE-331. Newton Square, PA: USDA Forest Service, Northeastern Research Station: 2-13.

Houston, D.R.; O’Brien, J.T. 1983. Beech bark disease. Forest Insect and Disease Leaflet 75. Washington, DC. USDA. 8 p.

Houston, D.R.; Mahoney, E.M. 1987. Beech bark disease: association of Nectria ochroleuca in West Virginia, Pennsylvania, and Ontario. Phytopathology (abstract). 77(11): 1615.

Houston, D.R.; Valentine, H.T. 1988. Beech bark disease: The temporal pattern of cankering in aftermath forests of Maine. Canadian Journal of Forest Research 18: 38-42.

Houston, D.R.; Parker, E.J.; Lonsdale, D. 1979a. Beech bark disease: patterns of spread and development of the initiating agent Cryptococcus fagisuga. Canadian Journal of Forest Research. 9: 336-344.

Houston, D.R.; Parker, E.J.; Perrin, R.; Lang, K.L. 1979b. Beech bark disease: A comparison of the disease in North America, Great Britain, France, and Germany. European Journal of Forest Pathology 9: 199-211.

Houston, D.B.; Houston, D.R. 2000. Allozyme genetic diversity among Fagus grandifolia trees restistant or susceptible to beech bark disease in natural populations. Canadian Journal of Forest Research 30: 778789.

Houston, D.R.; Rubin, B.D.; Twery, M.J.; Steinman, J.R. 2005. Spatial and Temporal Development of Beech Bark Disease in the Northeastern United States. In: Evans, C.; Lucas, J.A.; Twery, M.J., eds. Beech bark disease: proceedings of the beech bark disease symposium, 
2004, Saranac Lake, NY. Gen. Tech. Rep. NE-331. Newton Square, PA: USDA Forest Service, Northeastern Research Station: 2-13.

Isaaks, E.H.; Srivastava, R.M. 1989. An Introduction to Applied Geostatistics. Oxford University Press, New York, NY.

Jakubas, W.J.; McLaughlin, C.R.; Jensen, P.G.; McNulty, S.A. 2005. Alternate year beechnut production and its influence on bear and marten populations. In: Evans, C.; Lucas, J.A.; Twery, M.J., eds. Beech bark disease: proceedings of the beech bark disease symposium, 2004, Saranac Lake, NY. Gen. Tech. Rep. NE-331. Newton Square, PA: USDA Forest Service, Northeastern Research Station: 79-87.

Jalas, J,; Suominen, J. 1991. Atlas flora Europaeae: distribution of vascular plants in Europe 1-9. Akateminen Kirjakauppa, Helsinki.

Kasson, M.T.; Livingston, W.H. 2009. Spatial distribution of Neonectria species associated with beech bark disease in northern Maine. Mycologia 101: 190-195.

Kasson, M.T.; Livingston, W.H. 2012. Relationships among beech bark disease, climate, radial growth response and mortality of American beech in northern Maine, USA. Forest pathology 42: 199-212.

Kim, J.W. 1988. The physiology of forest vegetation on Ulreung-do, Korea. Phytocoenologia 16: 259-281.

Koch, J.L.; Carey, D.W. 2005. The genetics of resistance of American beech to beech bark disease: knowledge through 2004. In: Evans, C.; Lucas, J.A.; Twery, M.J., eds. Beech bark disease: proceedings of the beech bark disease symposium, 2004, Saranac Lake, NY. Gen. Tech. Rep. NE-331. Newton Square, PA: USDA Forest Service, Northeastern Research Station: 98105.

Koch, R.L.; Galvan, T.L. 2008. Bad side of a good beetle: the North American experience with Harmonia axyridis. BioControl 53: 23-35.

LaGuerrier, C.; Marceau, D.J.; Bouchard, A.; Brisson, J. 2003. A modeling approach to assess the long term impact of beech bark disease in northern hardwood forest. Canadian Journal of Forest Research 33: 2416-2425.

LaMadeleine, L.A. 1973. Electrophoretic differentiation of several species of Nectria. MS thesis, University of New Hampshire. Durham. 36 p.

Latty, E.F. 2005. Stand-level Patterns and Ecosystem Consequences of Beach Bark Disease. In: Evans, C.; Lucas, J.A.; Twery, M.J., eds. Beech bark disease: proceedings of the beech bark disease symposium, 2004, Saranac Lake, NY. Gen. Tech. Rep. NE-331. Newton Square, PA: USDA Forest Service, Northeastern Research Station: 98-105. 
Latty, E.F.; Canham, C.D.; Marks, P.L. 2003. Beech bark disease in northern hardwood forests: the importance of nitrogen dynamics and forest history for disease severity.

Leak, W.B. 2006. Fifty-year impacts of the beech bark disease in the Bartlett Experimental Forest, New Hampshire. Northern Journal of Applied Forestry 23(2): 141-143.

Leak, W.B.; Filip, S.M. 1977. Thirty-eight years of group selection in New England northern hardwoods. Journal of Forestry. 75: 641-643.

Little, E.L.; Jr. 1953. Check list of the native and naturalized trees of the United States (including Alaska). USDA Handbook 41. 472 p.

Little, E.L., Jr. 1965. Mexican beech, a variety of Fagus grandifolia. Castanea 30: 167-170.

Little, E.L.; Jr. 1979. Checklist of United States trees (native and naturalized). Agricultural Handbook No. 541. USDA Forest Service, Washington, D.C.

Lohman, M.L.; Watson, A.J. 1943. Identity and host relations of Nectria species associated with diseases of hardwoods in the eastern states. Lloydia. 6: 77-108.

Lonsdale, D. 1979. Nectria infection of beech bark in relation to infestation by Cryptococcus fagisuga Lindiger. European Journal of Forest Pathology 10: 161-168.

Lonsdale, D. 1980. Nectria coccinea infection of beech bark: variations in disease in relation to predisposing factors. Annals of Forest Science 37: 307-317.

Lonsdale, D. 1983a. Wood and bark anatomy of young beech in relation to Cryptococcus attack. In: Houston, D.R. 1983. Proceedings of the IUFRO beech bark disease workshop party conference; 1982 September 26-October 8; Hamden, CT. Gen. Tech. Rep. WO-37. Washington, DC: USDA Forest Service: 99-104.

Lonsdale, D. 1983b. Fungal associations in the build-up and decline of Cryptococcus fagisuga populations. In: Houston, D.R. 1983. Proceedings of the IUFRO beech bark disease workshop party conference; 1982 September 26-October 8; Hamden, CT. Gen. Tech. Rep. WO-37. Washington, DC: USDA Forest Service: 99-104.

Lovett, G.M.; Mitchell, M.J. 2004. Sugar maple and nitrogen cycling in the forests of eastern North America. Frontiers in Ecology and Environment 2: 81-88.

Lovett, G.M.; Canham, C.D.; Arthur, M.A.; Weathers, K.C.; Fitzhugh, R.D. 2006. Forest ecosystem responses to exotic pests and pathogens. Bioscience 56: 395-405.

MacKenzie, M. 2004. Survival of the fittest: beech bark disease-resistant beech will leave more offspring. In: Evans, C.; Lucas, J.A.; Twery, M.J., eds. Beech bark disease: proceedings of the beech bark disease symposium, 2004, Saranac Lake, NY. Gen. Tech. Rep. NE-331. Newton Square, PA: USDA Forest Service, Northeastern Research Station: 65-67. 
Mahoney, E.M.; Milgroom, M.G.; Sinclair, W.A. 1999. Origin, genetic diversity, and population structure of Nectria coccinea var. faginata in North America. Mycologia 91(4): 583-592.

Manion, P.D. 1991. Tree disease concepts, second editon. Englewood Cliffs, NJ: Prentice Hall Inc. $402 \mathrm{p}$.

Mantiri, F.R.; Samuels, G.J.; Rahe, J.E.; Honda, B.M. 2001. Phylogenetic relationships in Neonectria species having Cylindrocarpon anamorphs inferred from mithochondrial ribosomal DNA sequences. Canadian Journal of Botany 79:334-340.

Mayer, M.; Allen, D.C. 1983. Chilocorus stigma (Coleoptera: Coccinallidae) and other predators of the beech scale in central New York. In: Houston, D.R. 1983. Proceedings of the IUFRO beech bark disease workshop party conference; 1982 September 26-October 8; Hamden, CT. Gen. Tech. Rep. WO-37. Washington, DC: USDA Forest Service: 99-104.

McGee, G.G. 2000. The contribution of beech bark disease-induced mortality to coarse woody debris loads in northern hardwood stands of Adirondack Park, New York, U.S.A. Canadian Journal of Forest Research. 30: 1453-1462.

McLaughlin, C.R.; Matula Jr., G.J.; O’Connor, R.J. 1994. Synchronous reproduction by Maine black bears. International Conference on Bear Research and Management 9: 471-479.

Mielke, M.E.; Houston, D.R.; Bullard, A.T. 1986. Beech bark disease management alternatives. In: Proceedings, Integrated Pest Management symposium for northern forests. University of Wisconsin Extension Service, Madison, WI: 272-280.

Mize, C.W.; Lea, R.V. 1979. The effect of beech bark disease on the growth and survival of beech in northern hardwoods. European Journal of forest Pathology. 9: 243-248.

Morin, R.S.; Liebhold, A.M.; Luzader, E.R.; Lister, A.J.; Gottschalk, K.W.; Twardus, D.B. 2005. Mapping host-species abundance of three major exotic forest pests. Res. Pap. NE-276. Newton Square, PA: USDA Forest Service, Northeastern Research Station 11p.

Morin, R.S.; Liebhold, A.M.; Tobin, P.C.; Gottschalk, K.W.; Luzader, E. 2007. Spread of beech bark disease in the eastern United States and its relationship to regional forest composition. Canadian Journal of Forest Research 37: 726-736.

Nelson, P.E.; Toussoun, T.A; Marasas, W.F.O. 1983. Fusarium species: an illustrated manual for identification. The Pennsylvania State University Press. State College, PA.

Ostrofsky, W.D.; McCormack Jr., M.L. 1986. Silvicultural management of beech and the beech bark disease. Northern Journal of Applied Forestry. 3: 89-91.

Ostrofsky, W.D.; Houston, D.R. 1989. Harvesting alternatives for stands damaged by the beech bark disease. Proceedings of the Society of American Foresters National Convention; 1988 October 16-19. SAF Pub. No. 88-01. 
Ostrofsky, W.D.; Seymour, R.S.; Lemin, R.C. 1986. Damage to northern hardwoods from thinning using whole tree harvesting technology. Canadian Journal of Forest Research. 16: 12381244.

Painter, R.H. 1951. Insect resistance in crop plants. The Macmillan Co. New York, NY. 520p. Painter, R.H. 1958. Resistance of plants to insects. Annual Review of Entomology 3: 267-290.

Palande, P.R.; Pokharkar, D.S. 2005. Evaluation of Verticillium lecanii against Brevicoryne brassicae on cole crops. Annals of Plant Protection Science 13(1): 213-269.

Panda, N.; Khush, G.S1995. Host plant resistance to insects. CAB International, Wallingford, UK. 444p.

Park, Y.L.; Tollefson, J.J. 2005. Characterization of the spatial dispersion of corn root injury by corn rootworms (Coleoptera: Chrysomelidae). Journal of Economic Entomology 98(2): 378-383.

Park, Y.L.; Perring, T.M.; Krell, R.K.; Hashim-Buckey, J.M,; Hill, B.L. 2011. Spatial distribution of Pierce's Disease related to incidence, vineyard characteristics, and surrounding land uses. American Journal of Enology and Viticulture 62(2): 229-238.

Parker, E.J. 1980. Population trends of Cryptococcus fagisuga Lindinger following different thinning intensities of young beech. Annals of Forest Science 37: 299-306.

Parker, E.J. 1983. Beech bark diseases in Great Britain. In: Houston, D.R. 1983. Proceedings of the IUFRO beech bark disease workshop party conference; 1982 September 26-October 8; Hamden, CT. Gen. Tech. Rep. WO-37. Washington, DC: USDA Forest Service: 50-53.

Pedigo, L.P.; Rice, M.E. 2006. Entomology and Pest Management, $5^{\text {th }}$ ed. Prentice Hall. Upper Saddle River, NJ. 784p.

Perrin, R. 1983. Specificity of Cryptococcus fagisuga and Nectria coccinea association in beech bark disease in Europe. In: Houston, D.R. 1983. Proceedings of the IUFRO beech bark disease workshop party conference; 1982 September 26-October 8; Hamden, CT. Gen. Tech. Rep. WO37. Washington, DC: USDA Forest Service: 50-53.

Perrins, C.M. 1966. The effect of beech crops on Great Tit populations and movements. British Birds 59: 419-432.

Robb, J.R.; Bookhout, T.A. 1995. Factors influencing wood duck use of natural cavities. Journal of Wildlife Management 59: 372-383.

Raynor, G.S.; Hayes, J.V.; Ogden, E.C. 1974. Particulate dispersion into and within a forest. Boundary-layer Meteorology 7: 429-456.

Rossman, A.Y.; Samuels, G.J.; Rogerson, C.T.; Lowen, R. 1999. Genera of Bionectriaceae, Hypocreaceae and Nectriaceae (Hypocreales, Ascomycetes). Studies in Mycology 42: 1-248. 
Runkle, J.R. 1990. Eight years change in an old Tsuga Canadensis woods affected by beech bark disease. Bulletin of the Torrey botanical Club 117: 409-419.

Rushmore, F.M. 1961. Silvical characteristics of beech (Fagus grandifolia). USDA Forest Service Station Paper 161. Northeast Forest Experiment Station. 26p.

Rust S.; Savill P.S. 2000. The root systems of Fraxinus excelsior and Fagus sylvatica and their competitive relationships. Forestry 5: 499-508.

Samsinakova, A.; Kalalova, S. 1975. Artificial infection of scale insect with entomogenous fungi Verticillium lecanii and Aspergillus candidus. Entomophaga. 20: 361-364.

Scheffer, T.C.; Cowling, E.B. 1966. Natural resistance of wood to microbial deterioration. Annual Review of Phytopathology 4: 147-170.

Shannon, C. E.; Weaver W. 1948. A mathematical theory of communication. The Bell System Technical Journal 27: 379-423 and 623-656.

Shigo, A.L. 1962. Another scale insect on beech. USDA Forest Service Station Paper 168. Northeast Forest Experiment Station. 13 p.

Shigo, A.L. 1964. Organism interactions in the beech bark disease. Phytopathology 54: 263-269.

Shigo, A.L. 1972. The beech bark disease today in the northeastern United States. Journal of Forestry 70: 286-289.

Sinclair, W.; Lyon, H.H. 2005. Diseases of trees and Shrubs, $2^{\text {nd }}$ ed. Cornell University Press. Ithaca, NY.

Skelly, J.M; Wood, F.A. 1966. The occurrence and etiology of an annual canker of sugar maple in Pennsylvania. Canadian Journal of Botany 44: 1401-1411.

Spaulding, P.; Grant, T.J.; Ayres, T.T. 1936. Investigations of Nectria diseases in hardwoods of New England. Journal of Forestry 34: 169-171.

Speer, E.O.; Butin, H. 1980. Is there a relationship between Dichaena rugosa and beech bark disease. Annals of Forest Science 37: 357-359.

Storer, A.J.; Rosemeir, J.N.; Beachy, B.L.; Flaspohler, D.J. 2005. In: Evans, C.; Lucas, J.A.; Twery, M.J., eds. Beech bark disease: proceedings of the beech bark disease symposium, 2004, Saranac Lake, NY. Gen. Tech. Rep. NE-331. Newton Square, PA: USDA Forest Service, Northeastern Research Station: 72-78.

Toole, E.R. 1963. Cottonwood canker caused by Fusarium solani. Plant Disease Reporter 47: 1032-1035. 
Toole, E.R. 1966. Stem canker of red oak caused by Fusarium solani. Plant Disease Reporter 50: $160-161$.

Twery, M.J.; Patterson III, W.A. 1983. Effects of species composition and site factors on the severity of beech bark disease in western Massachusetts and the White Mountains of New Hampshire: a preliminary report. In: Houston, D.R. 1983. Proceedings of the IUFRO beech bark disease workshop party conference; 1982 September 26-October 8; Hamden, CT. Gen. Tech. Rep. WO-37. Washington, DC: USDA Forest Service: 99-104.

Twery, M.J.; Patterson III, W.A. 1984. Variations in beech bark disease and its effects on species composition and structure of northern hardwood stands in central New England. Canadian Journal of Forest Research. 14: 565-574.

USDA Forest Service. 1965. Silvics of forest tress of the United States. USDA Agricultural Handbook 271: 762 p. Washington D.C.

Wainhouse, D. 1980. Dispersal of first instar larvae of the felted beech scale Cryptococcus fagisuga. Journal of Applied Ecology 17: 523-532.

Wainhouse, D.; Gate, I.M. 1988. The beech scale. In: Berryman, A.A., ed. Dynamics of Forest Populations: Patterns, Causes, Implications. Plenum Press, NY.

Wainhouse D.; Howell, R.S. 1983. Intraspecific variation in beech scale populations and in susceptibility of their host Fagus sylvatica. Ecological Entomology. 8: 351-359.

Westveld, R.H. 1933. The relation of certain soil characteristics to forest growth and composition in the northern hardwood forest of northern Michigan. Michigan Agricultural Experiment Station technical Bulletin 135. 51p.

Willard, J.R. 1979. Dispersal of California red scale (Aonidiella aurantii (Maskell)) (Homoptera: Diaspididae) in relation to weather variables. Journal of the Australian Entomological Society. 15: 395-404.

Wollenweber, H.W. 1917. Fusaria autographice dilineata. Annals of mycology 15: 1-56.

Wolff, J.O. 1996. Population fluctuation of mast-eating rodents are correlated with production of acorns. Journal of Mammology 77: 850-856. 


\section{Appendix 1: Maps of Study Sites}

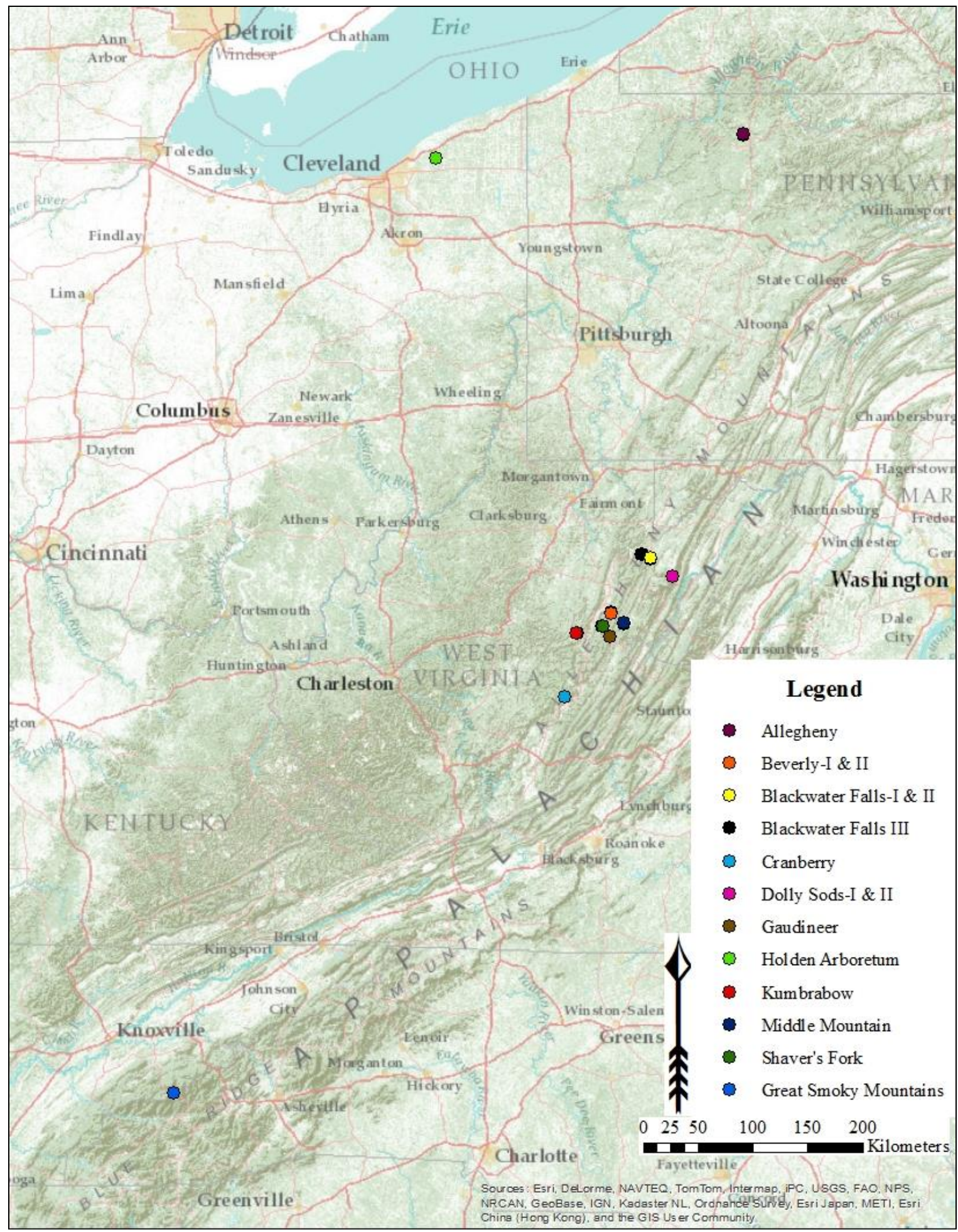

Figure 1: Map of all study sites in the Appalachian region. 


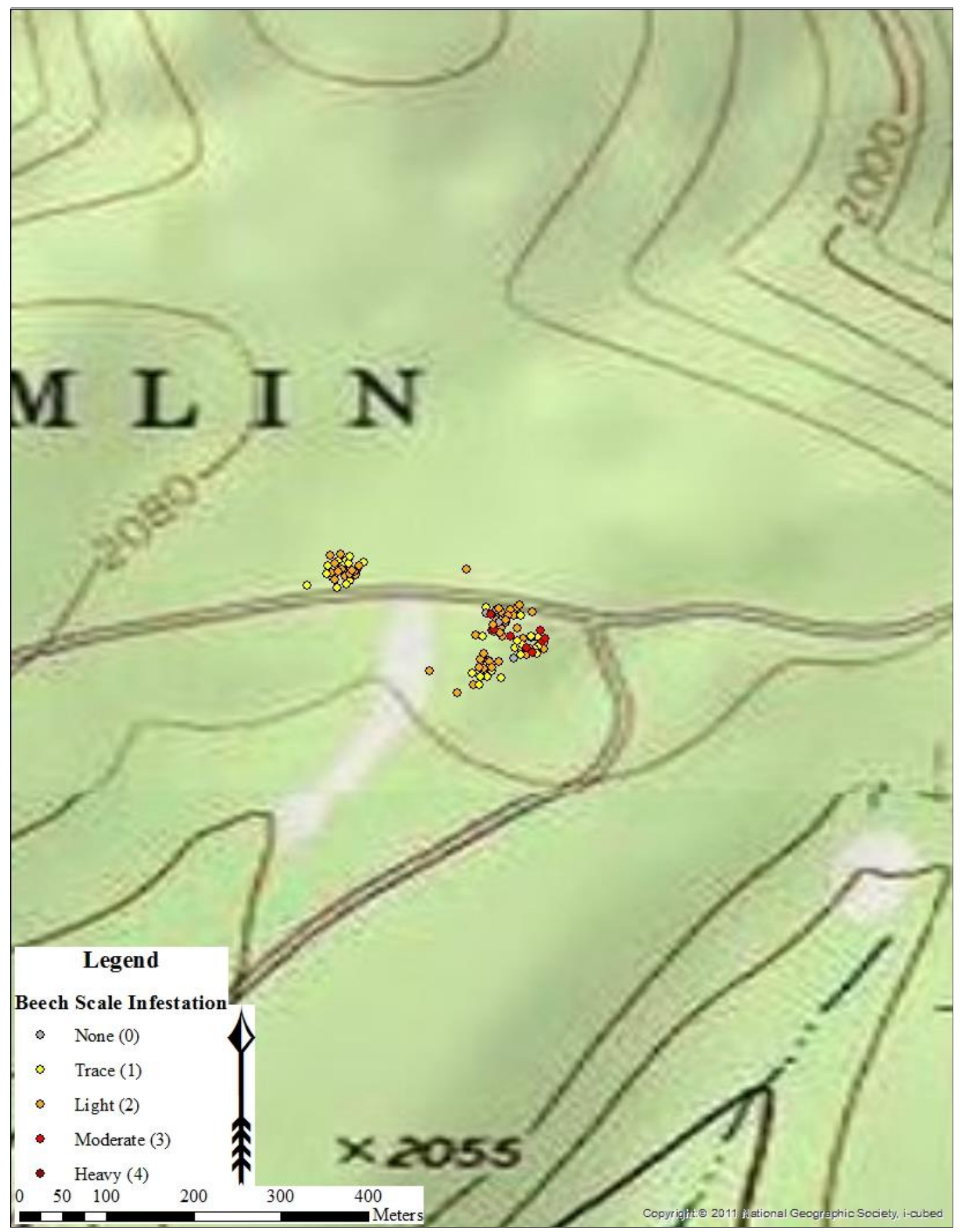

Figure 2: Distribution and Cryptococcus infestation of Fagus grandifolia at Allegheny National Forest Site, McKean County, PA (117 Fagus grandifolia sampled). 


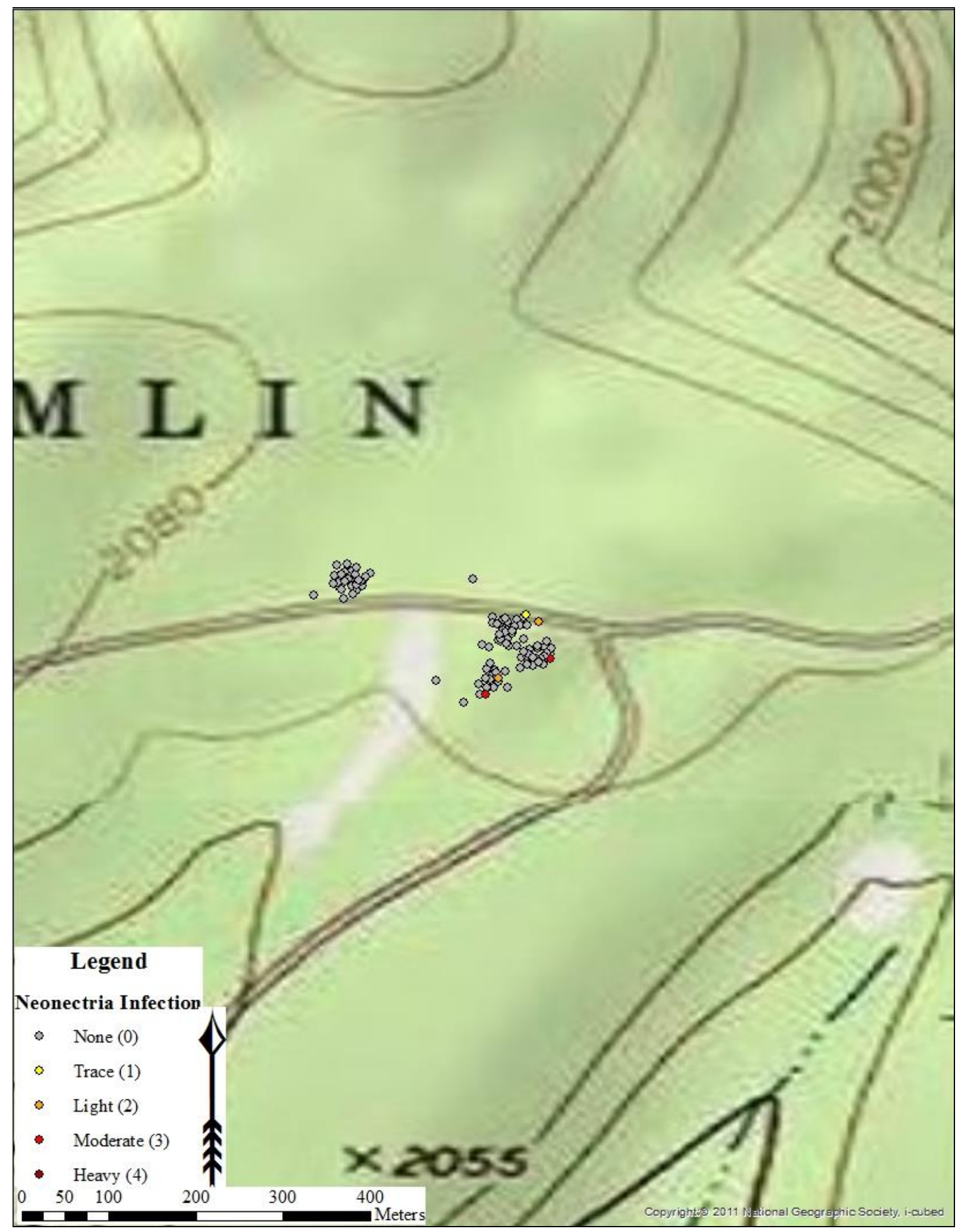

Figure 3: Distribution and Neonectria infection of Fagus grandifolia at Allegheny National Forest Site, McKean County, PA (117 Fagus grandifolia sampled). 


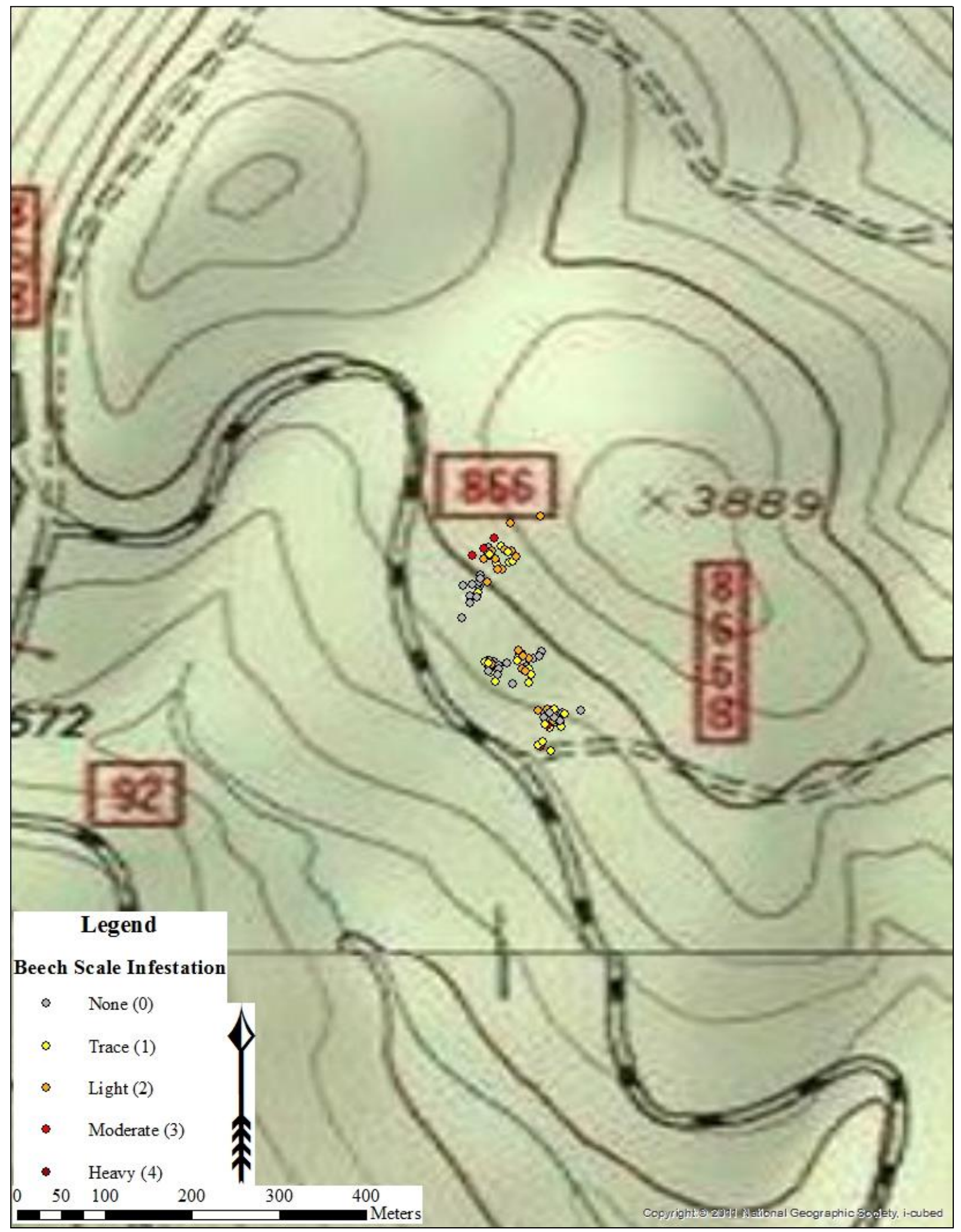

Figure 4: Distribution and Cryptococcus infestation of Fagus grandifolia at Beverly-I site, Randolph County, WV (95 Fagus grandifolia sampled). 


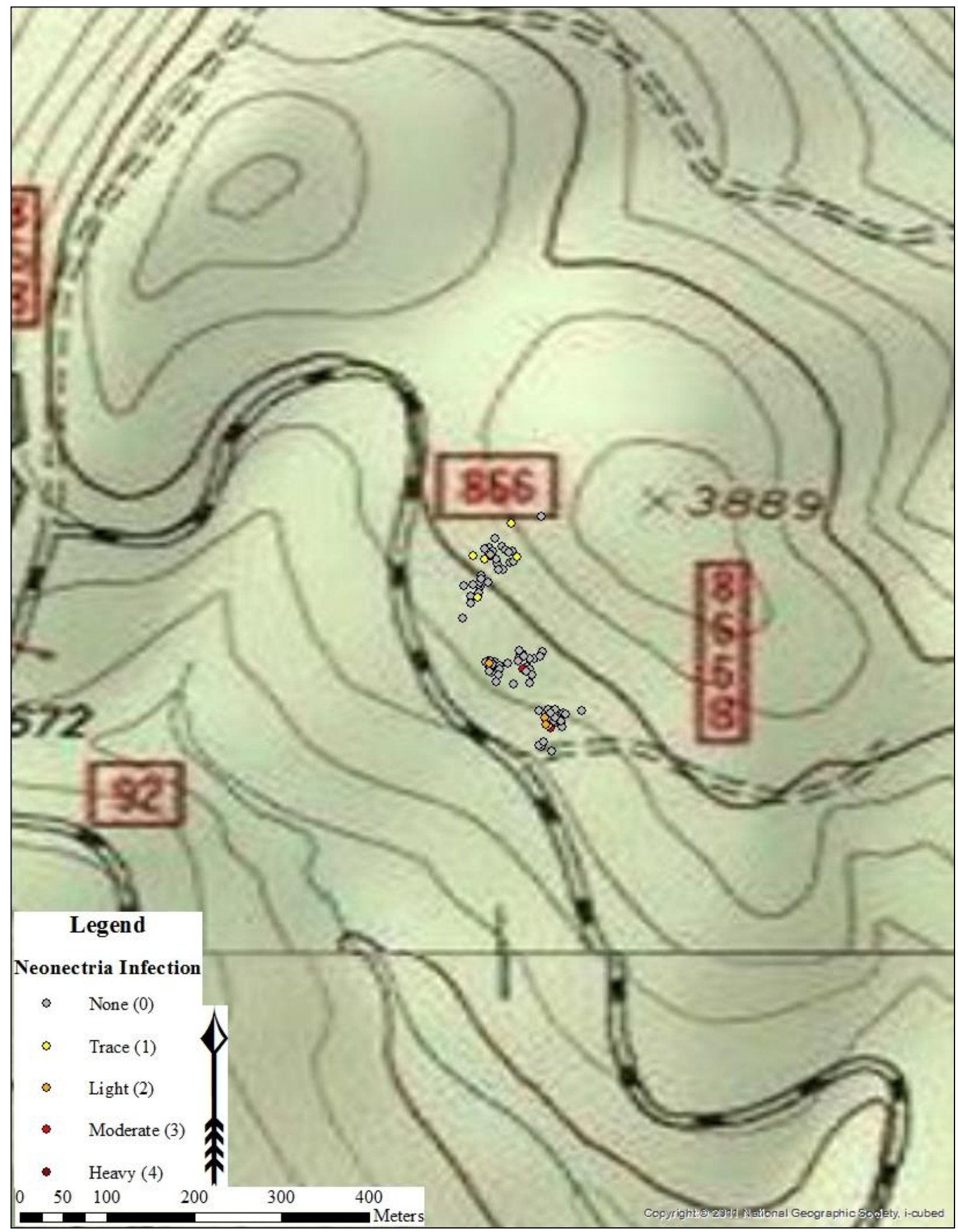

Figure 5: Distribution and Neonectria infection of Fagus grandifolia at Beverly-I site, Randolph County, WV (95 Fagus grandifolia sampled). 


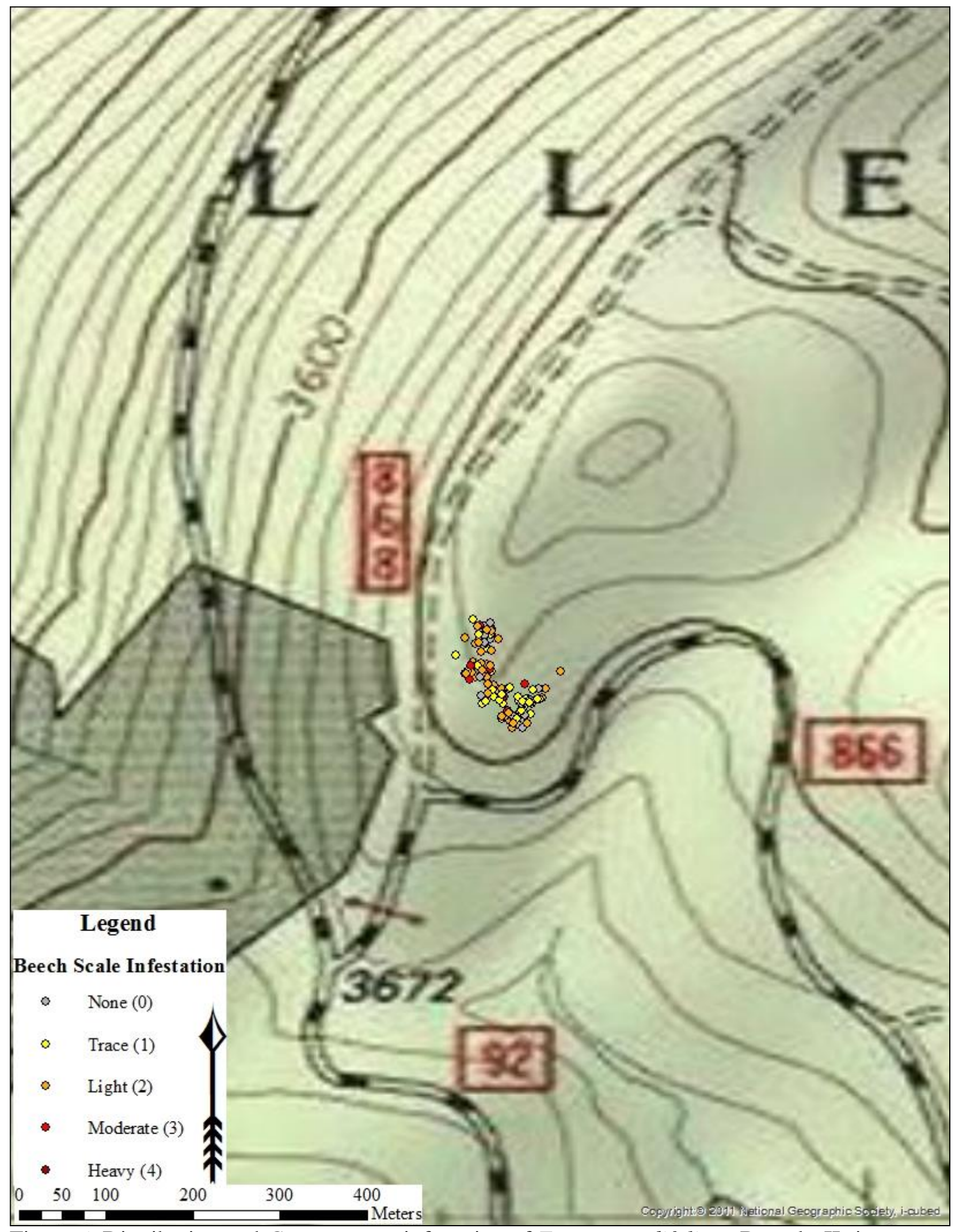

Figure 6: Distribution and Cryptococcus infestation of Fagus grandifolia at Beverly-II site, Randolph County, WV (122 Fagus grandifolia sampled). 


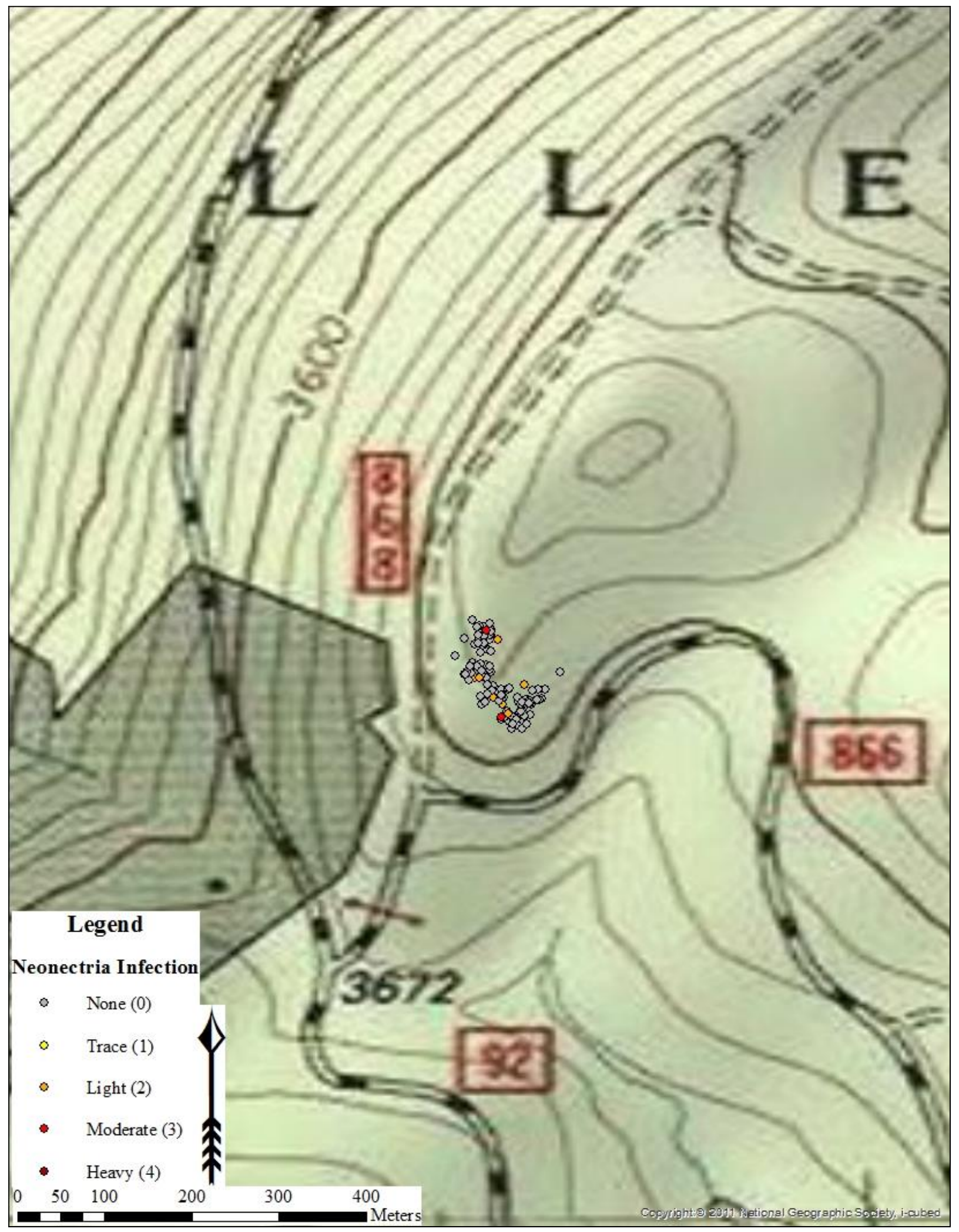

Figure 7: Distribution and Neonectria infection of Fagus grandifolia at Beverly-II site, Randolph County, WV (122 Fagus grandifolia sampled). 


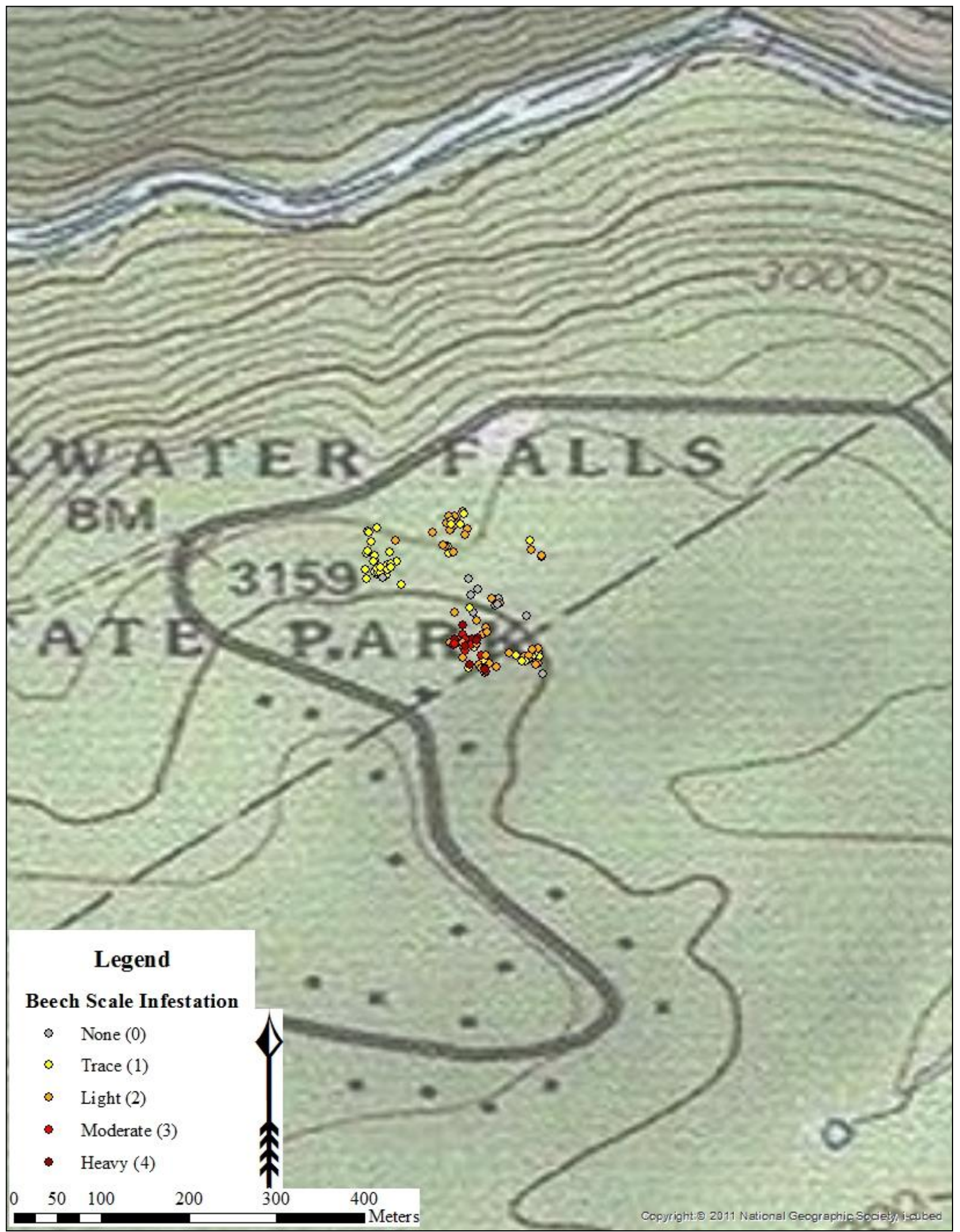

Figure 8: Distribution and Cryptococcus infestation of Fagus grandifolia at Blackwater Falls State Park-I site, Tucker County, WV (128 Fagus grandifolia sampled). 


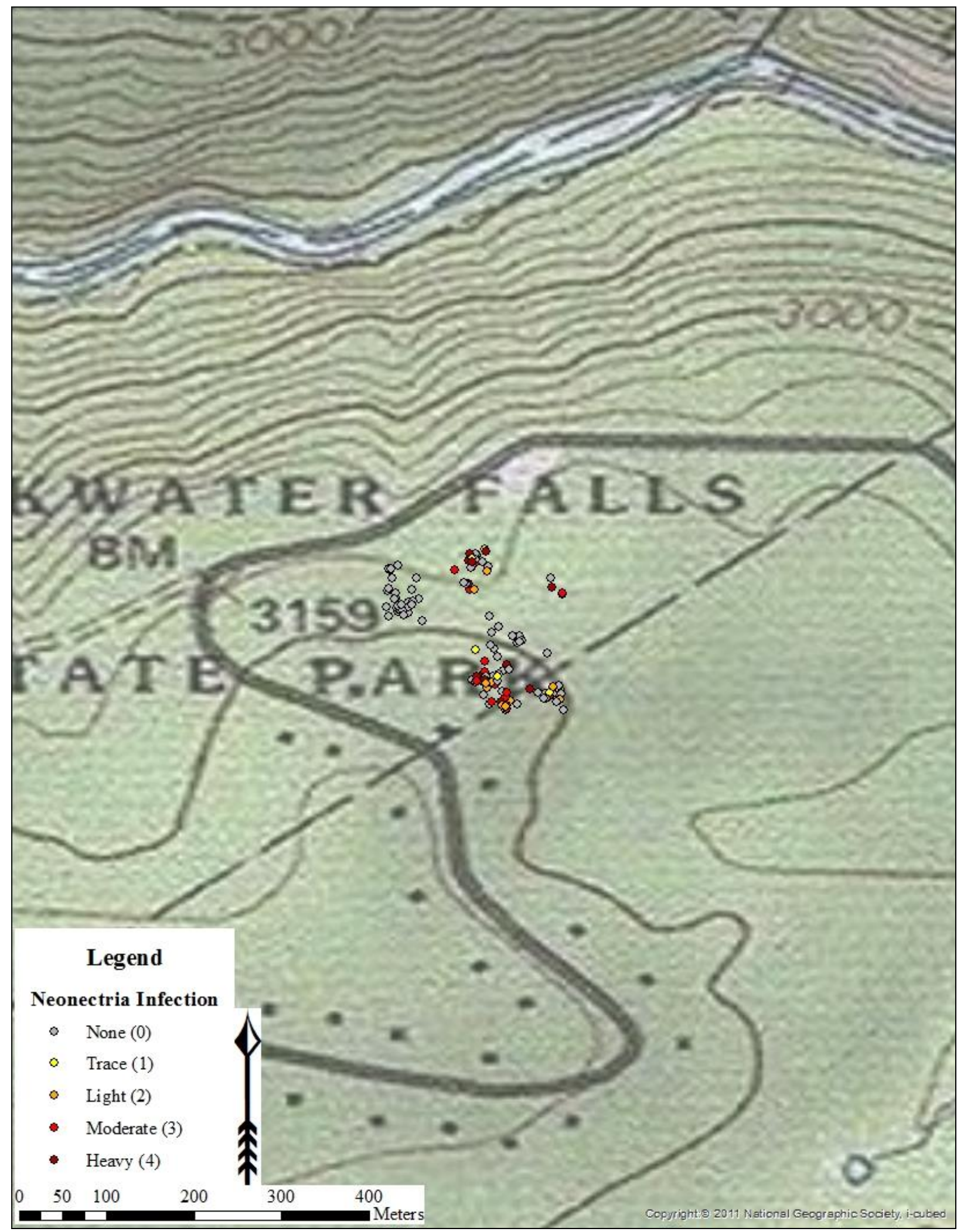

Figure 9: Distribution and Neonectria infection of Fagus grandifolia at Blackwater Falls State Park-I site, Tucker County, WV (128 Fagus grandifolia sampled). 


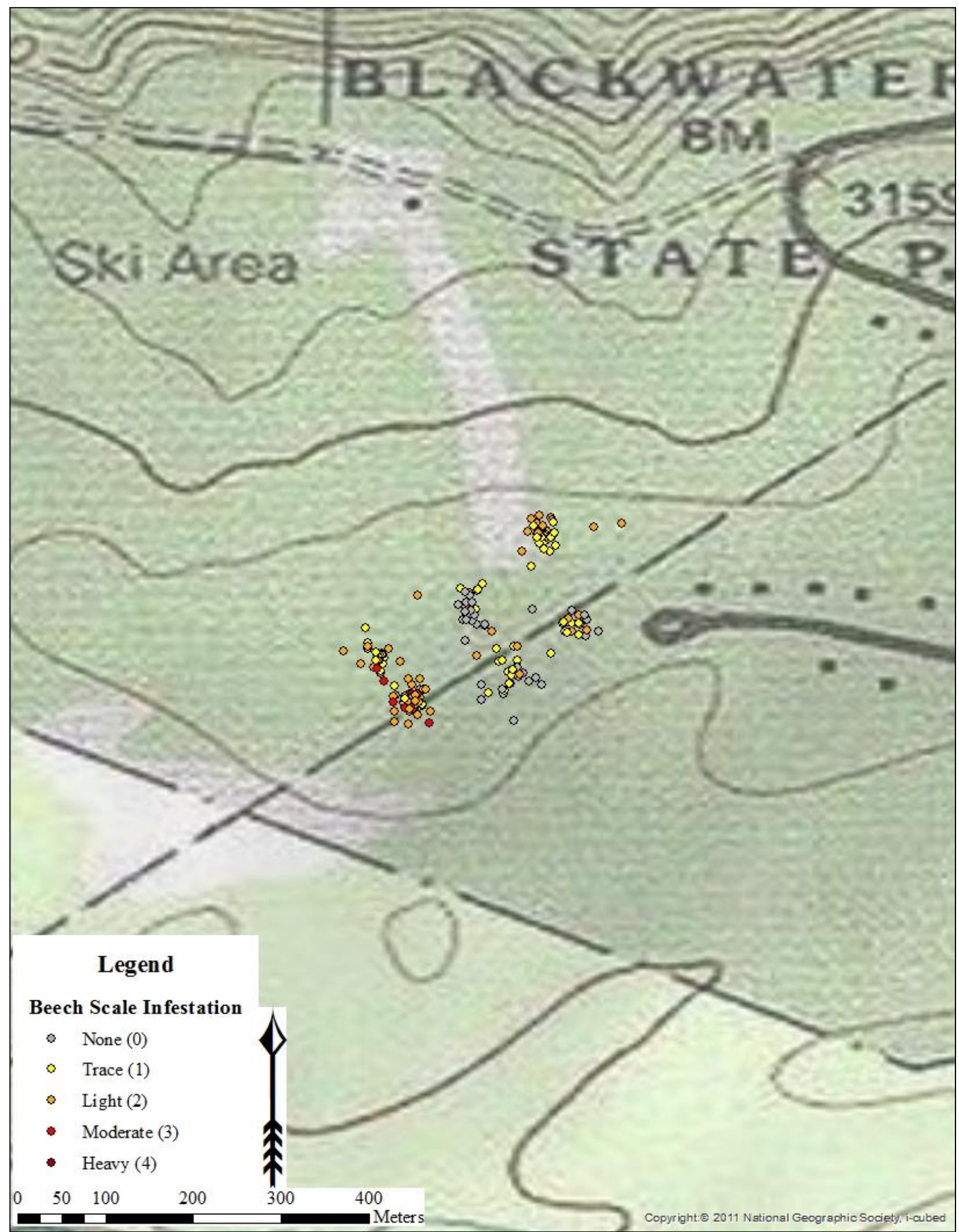

Figure 10: Distribution and Cryptococcus infestation of Fagus grandifolia at Blackwater Falls State Park-II site, Tucker County, WV (192 Fagus grandifolia sampled). 


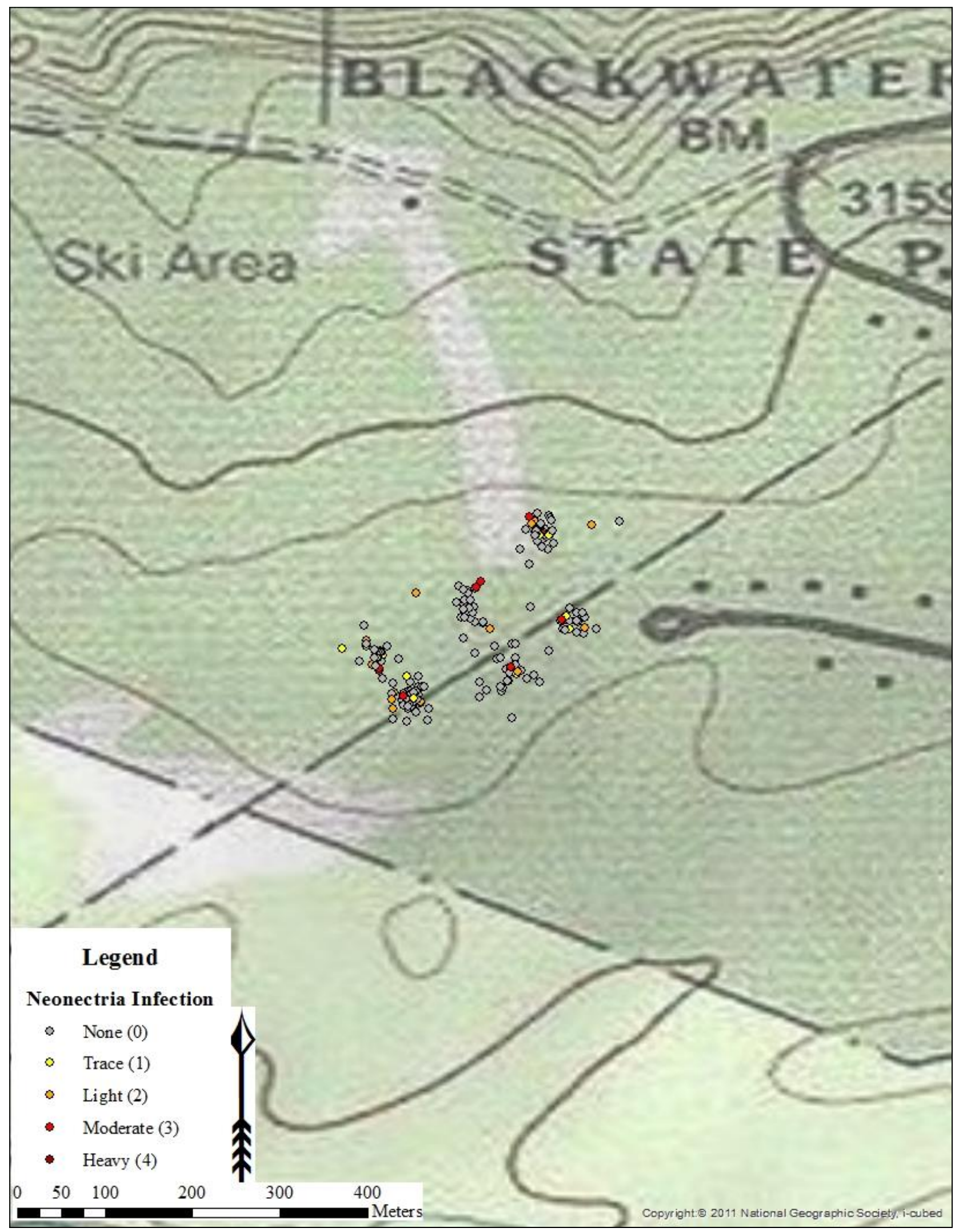

Figure 11: Distribution and Neonectria infection of Fagus grandifolia at Blackwater Falls State Park-II site, Tucker County, WV (192 Fagus grandifolia sampled). 


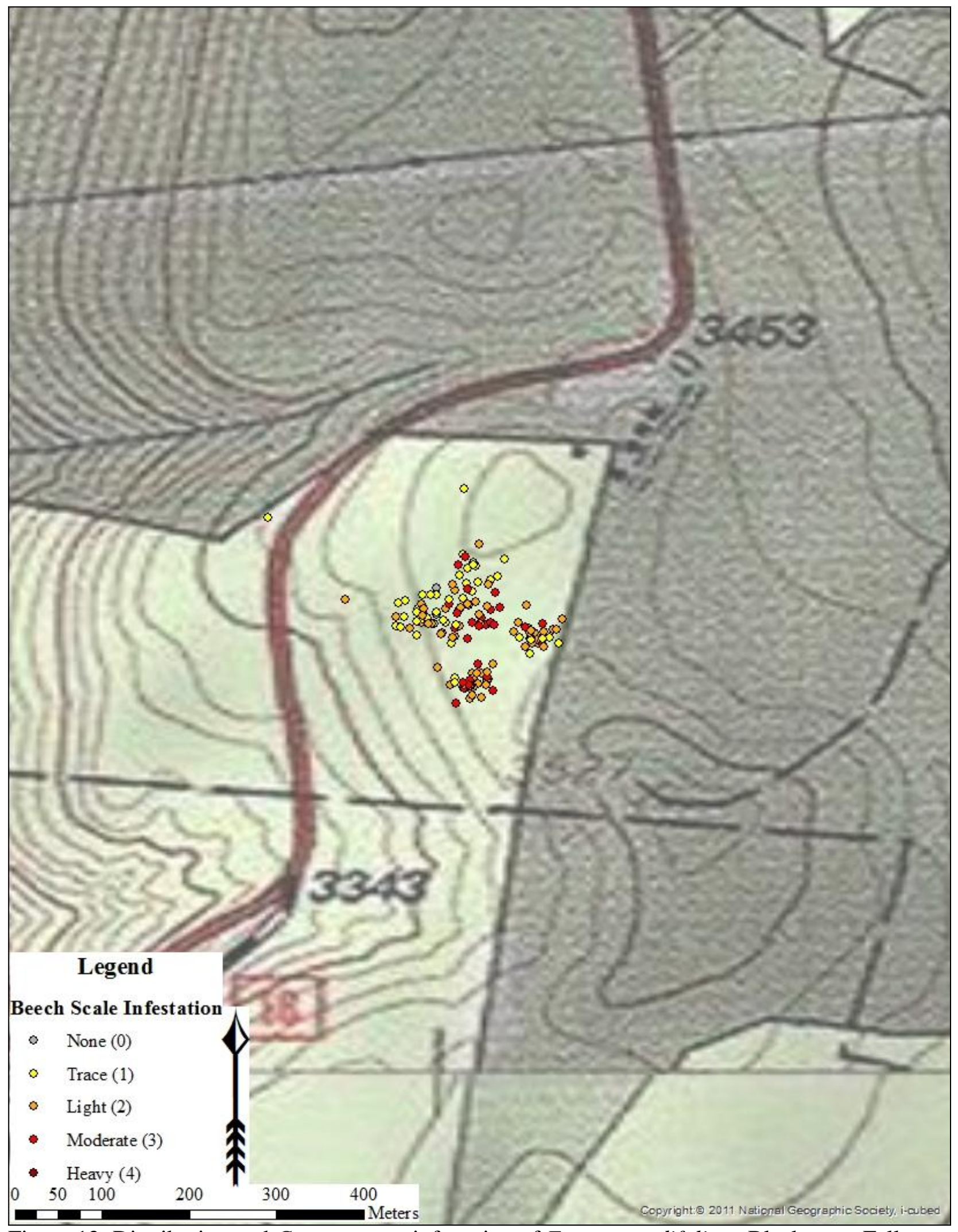

Figure 12: Distribution and Cryptococcus infestation of Fagus grandifolia at Blackwater Falls State Park-III site, Tucker County, WV (161 Fagus grandifolia sampled). 


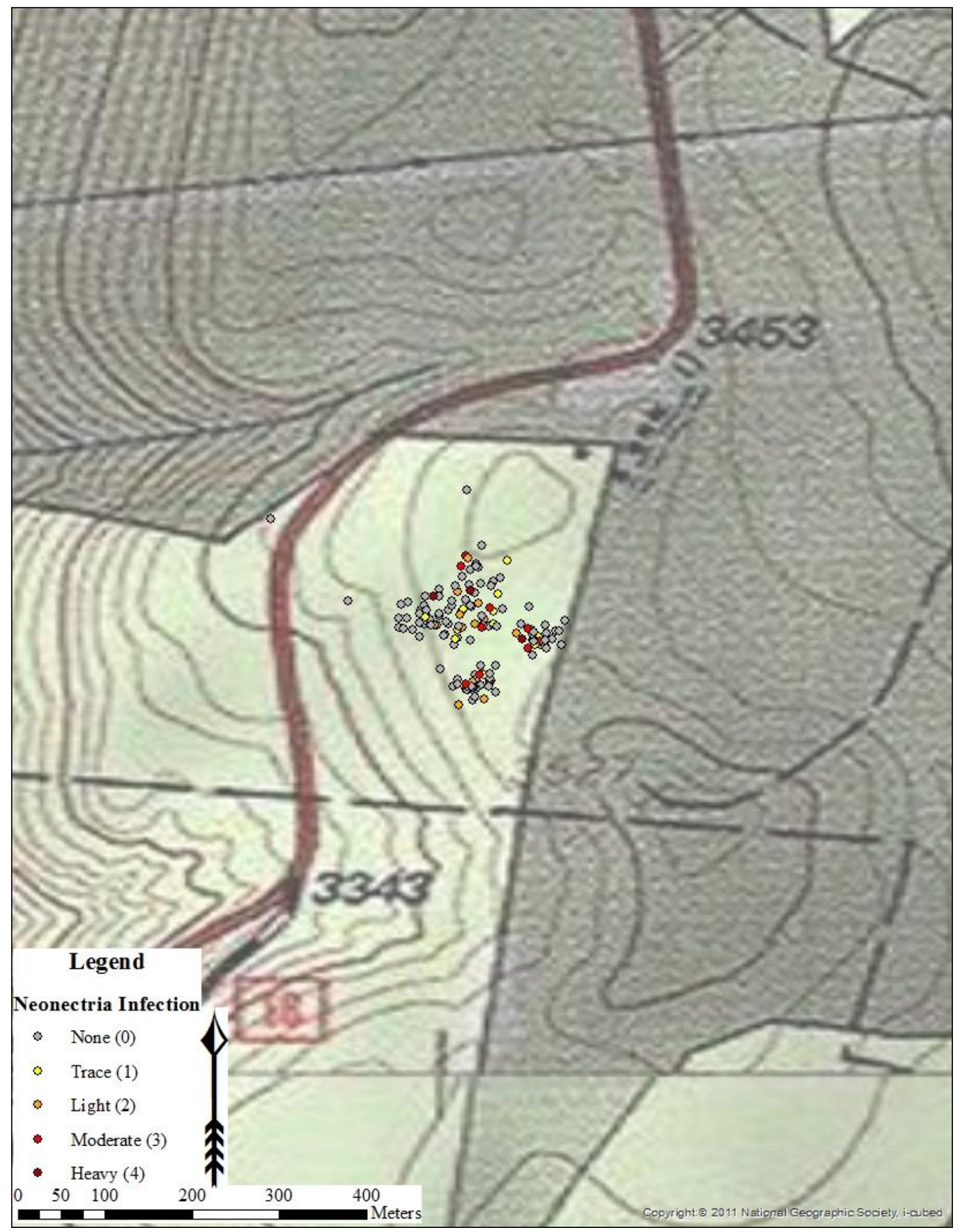

Figure 13: Distribution and Neonectria infection of Fagus grandifolia at Blackwater Falls State Park-III site, Tucker County, WV (161 Fagus grandifolia sampled). 


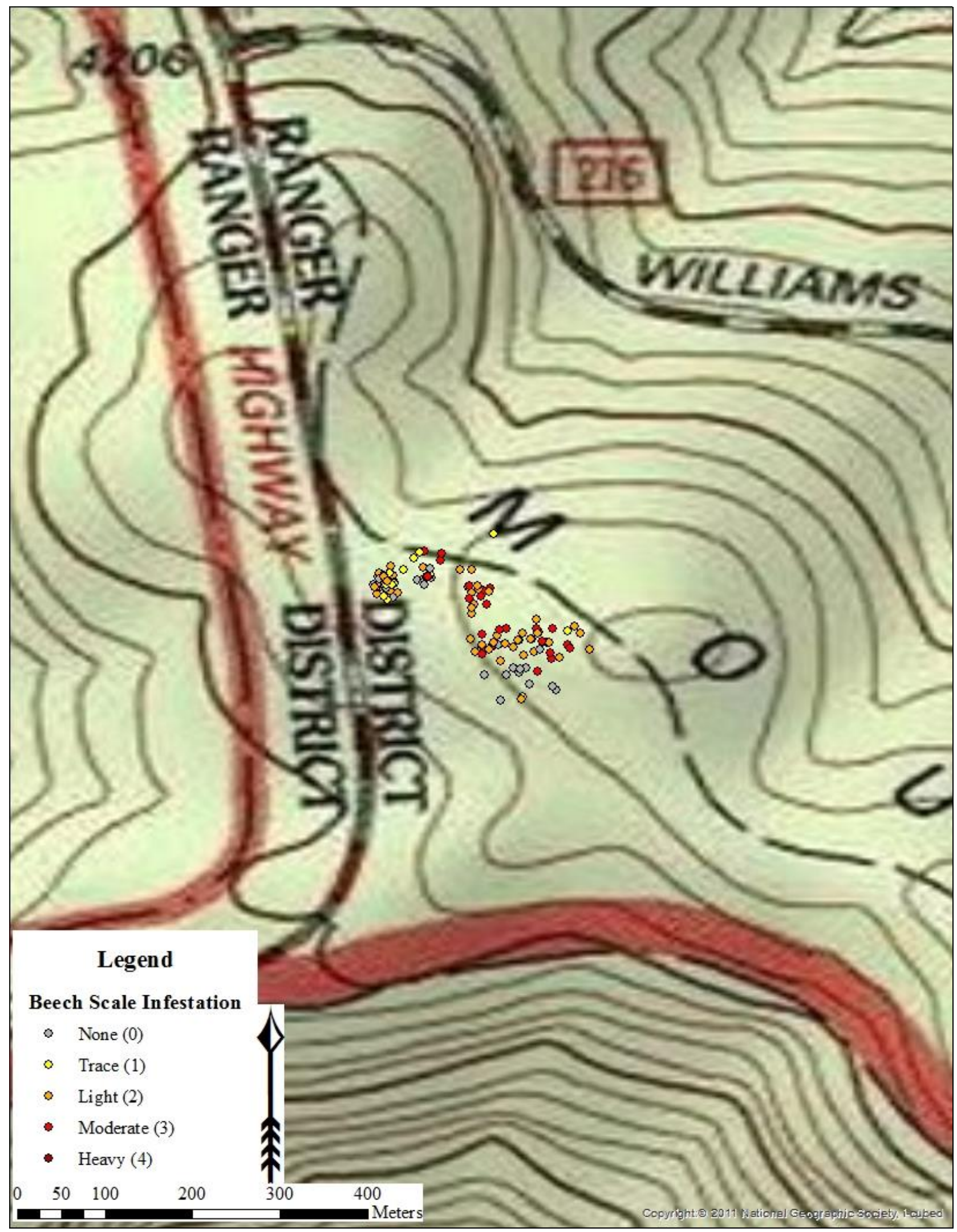

Figure 14: Distribution and Cryptococcus infestation of Fagus grandifolia at Cranberry Wilderness site, Pocahontas County, WV (126 Fagus grandifolia sampled). 


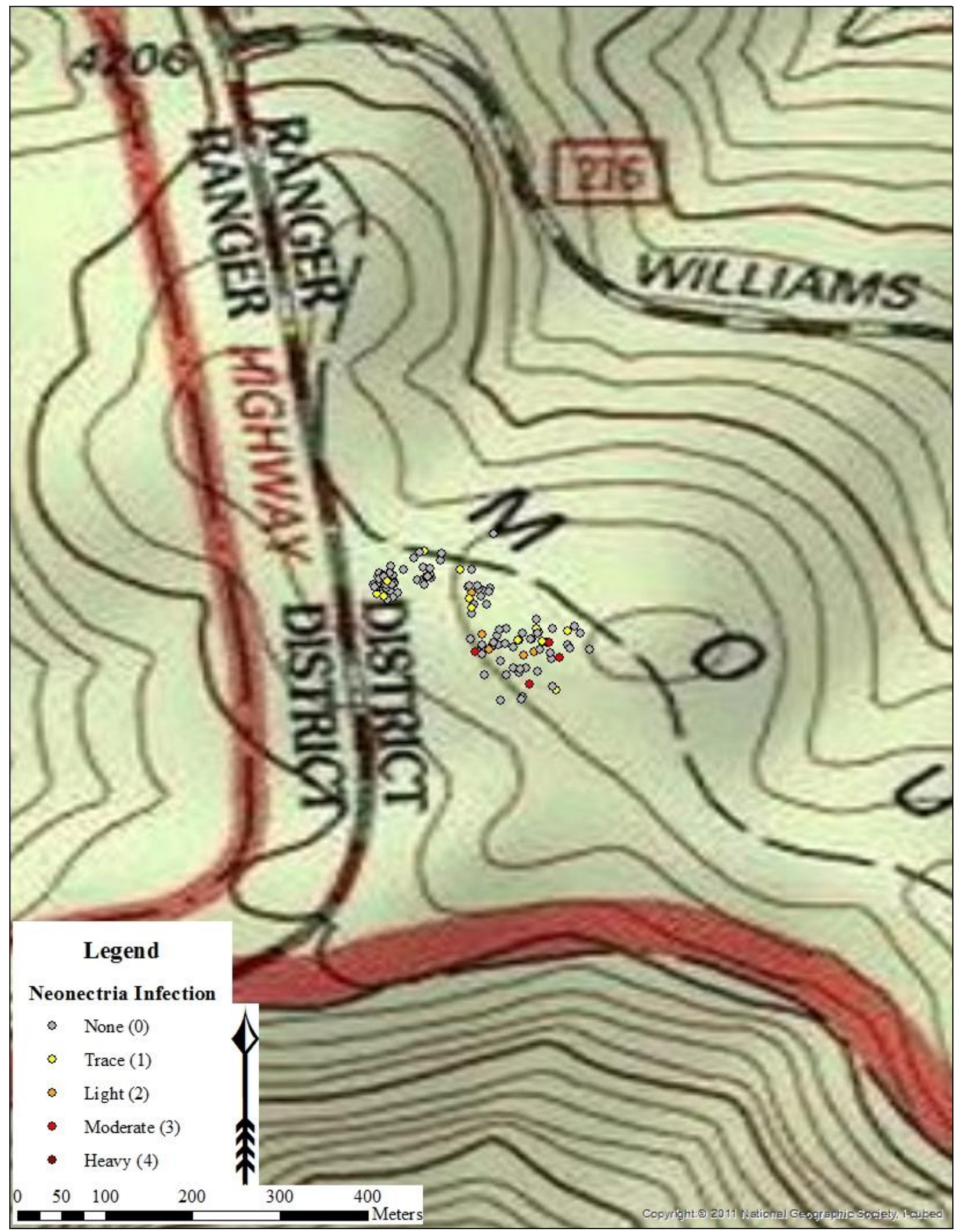

Figure 15: Distribution and Neonectria infection of Fagus grandifolia at Cranberry Wilderness site, Pocahontas County, WV (126 Fagus grandifolia sampled). 


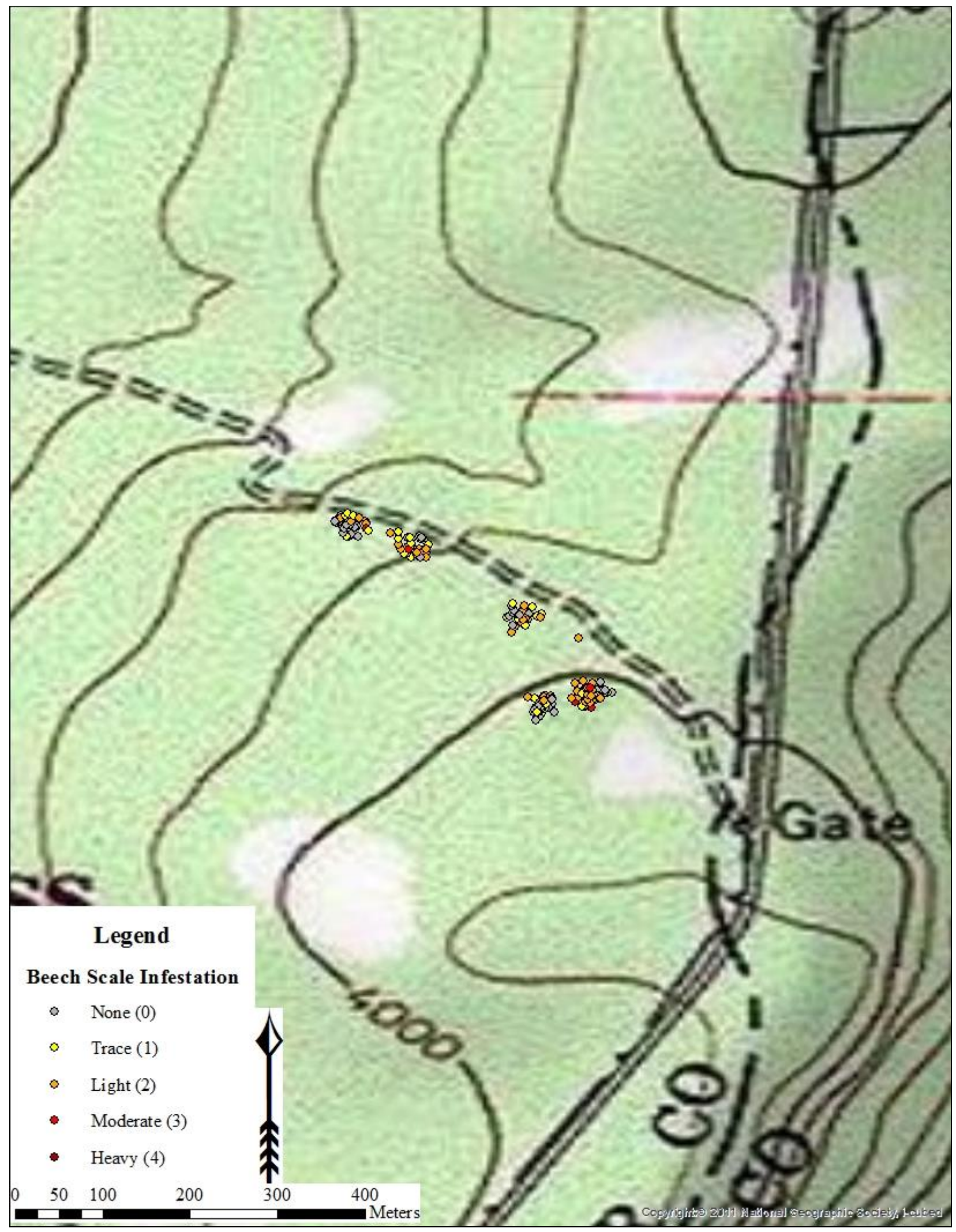

Figure 16: Distribution and Cryptococcus infestation of Fagus grandifolia at Dolly Sods Recreation Area-I site, Tucker County, W (220 Fagus grandifolia sampled). 


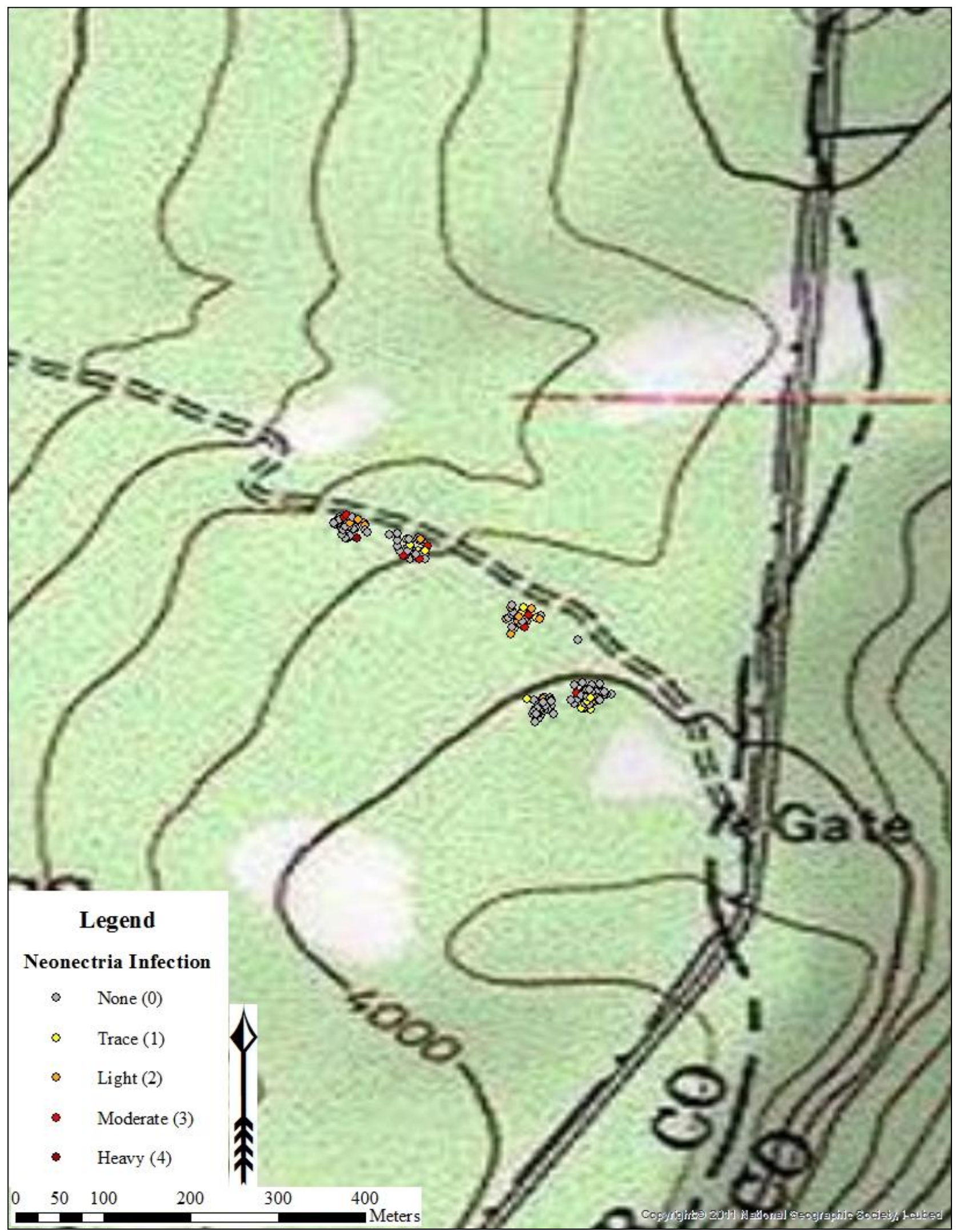

Figure 17: Distribution and Neonectria infection of Fagus grandifolia at Dolly Sods Recreation Area-I site, Tucker County, WV (220 Fagus grandifolia sampled). 


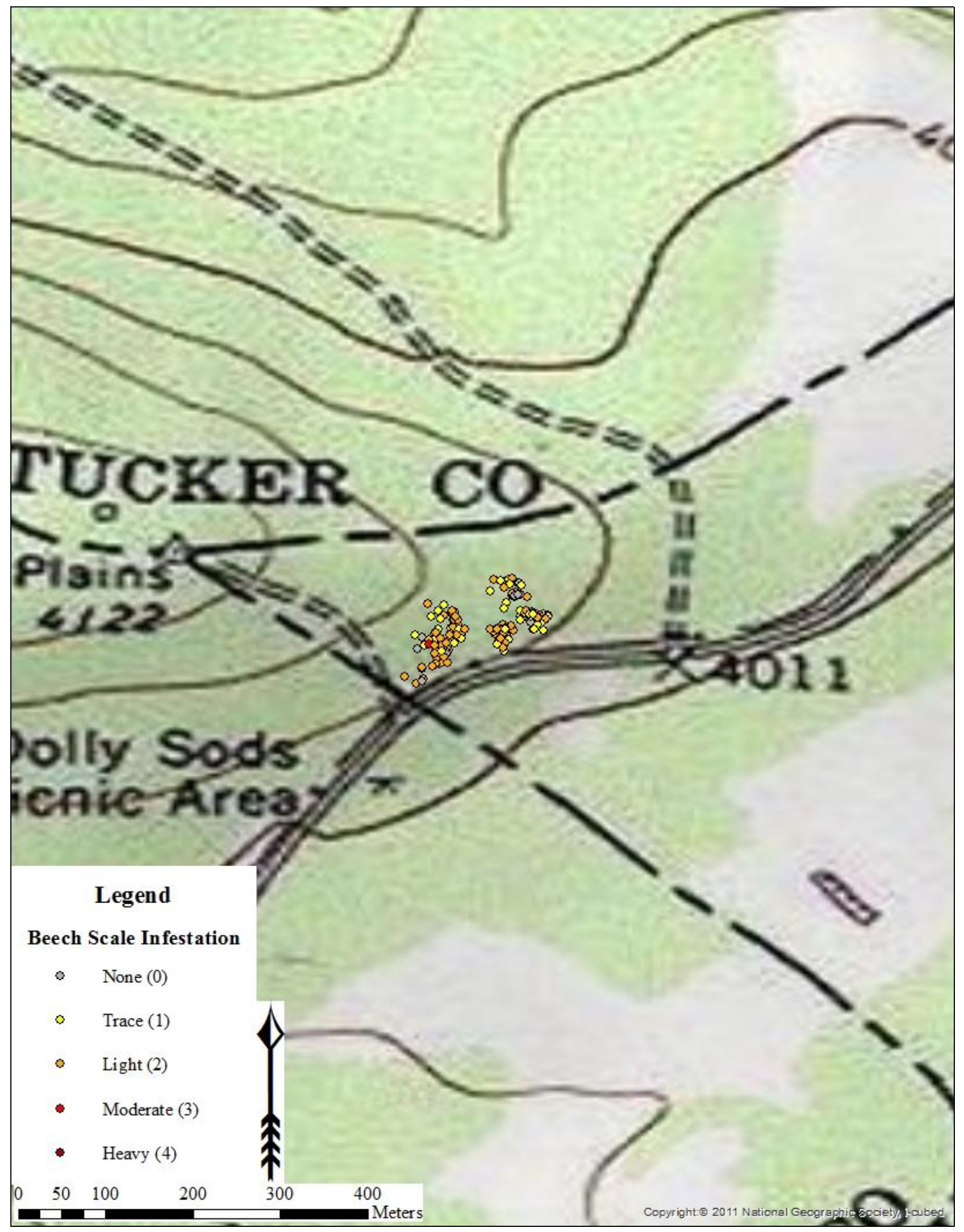

Figure 18: Distribution and Cryptococcus infestation of Fagus grandifolia at Dolly Sods Recreation Area-II site, Grant County, WV (227 Fagus grandifolia sampled). 


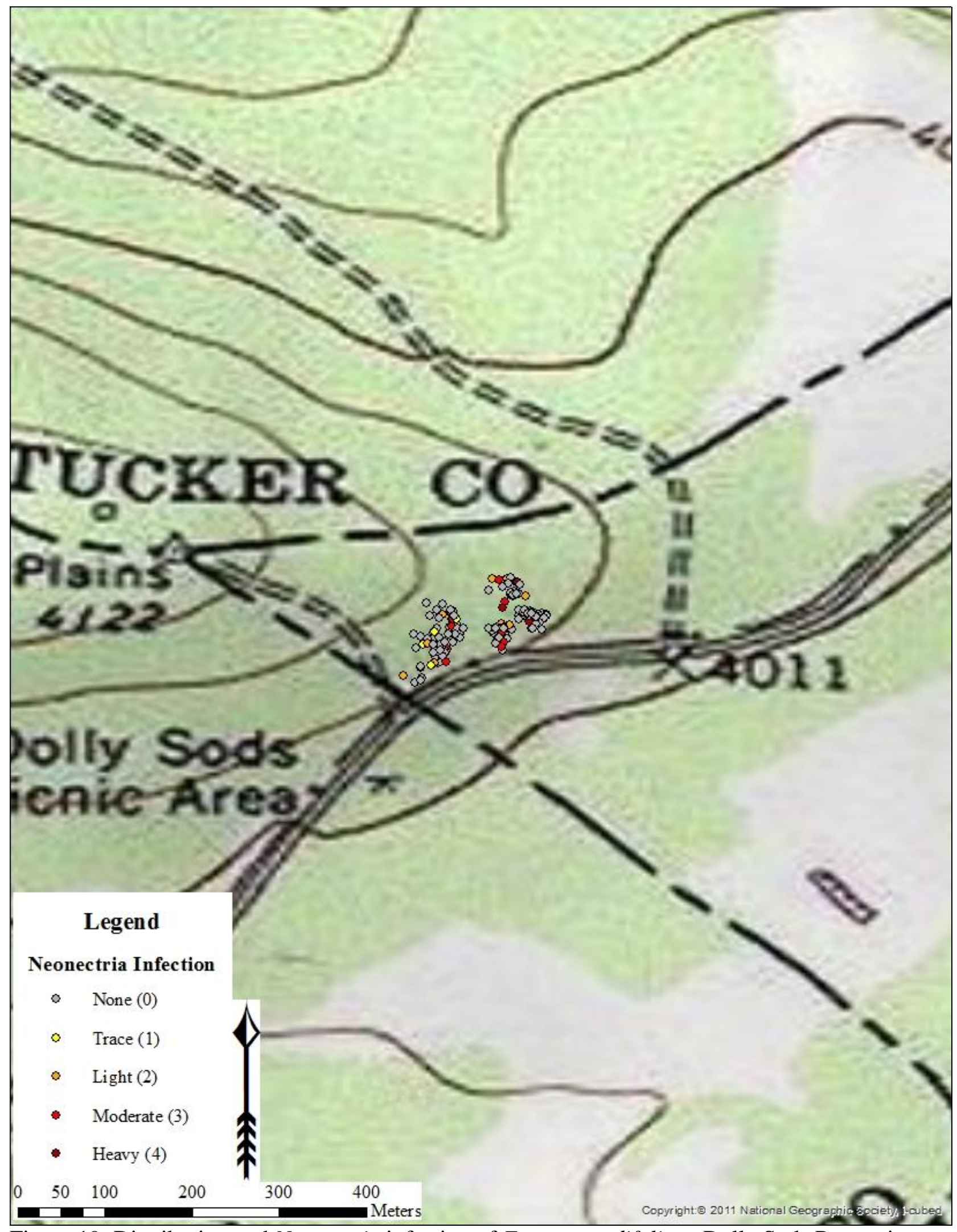

Figure 19: Distribution and Neonectria infection of Fagus grandifolia at Dolly Sods Recreation Area-II site, Grant County, WV (227 Fagus grandifolia sampled). 


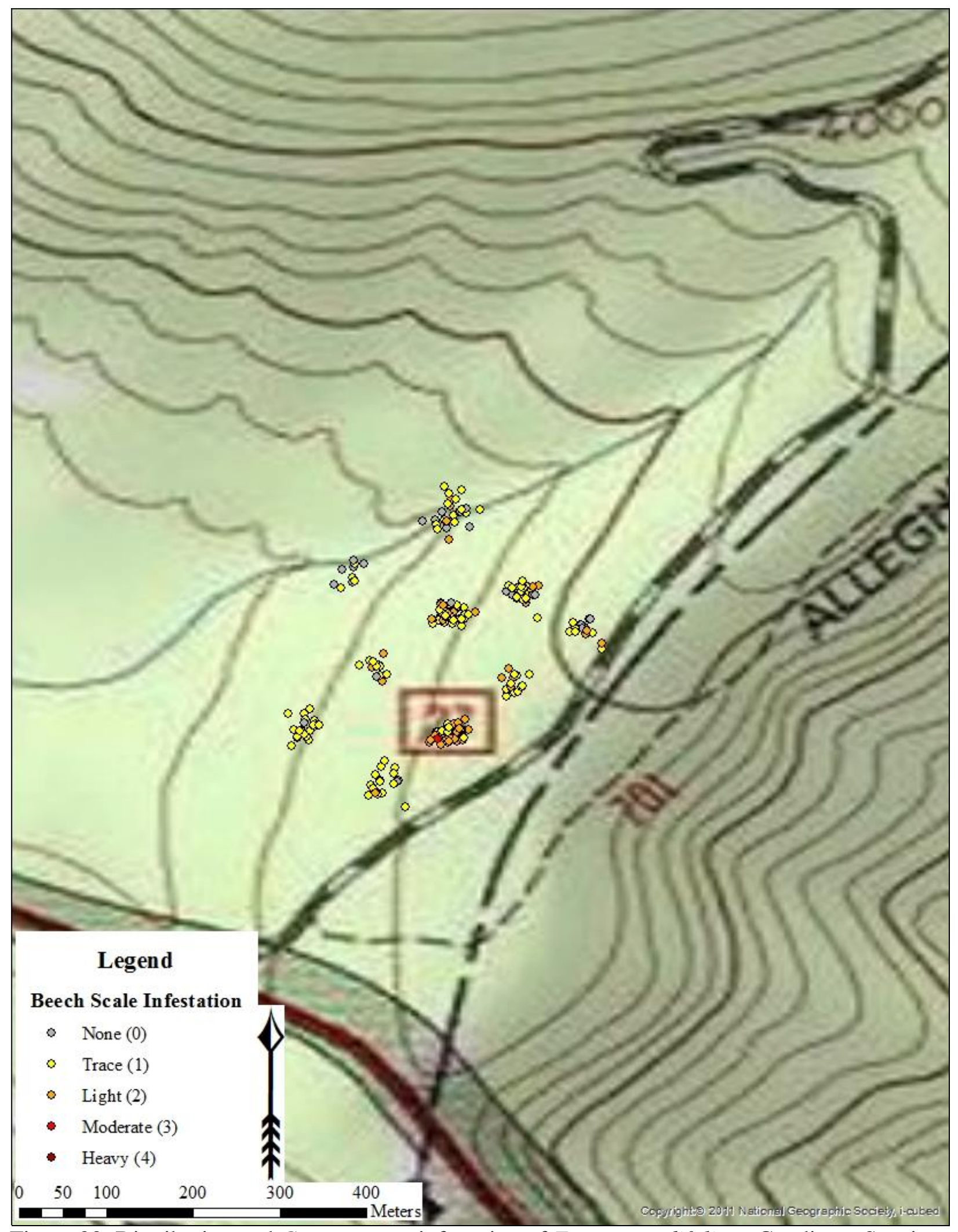

Figure 20: Distribution and Cryptococcus infestation of Fagus grandifolia at Gaudineer Scenic Area site, Monongahela National Forest, Randolph County, WV (261 Fagus grandifolia sampled). 


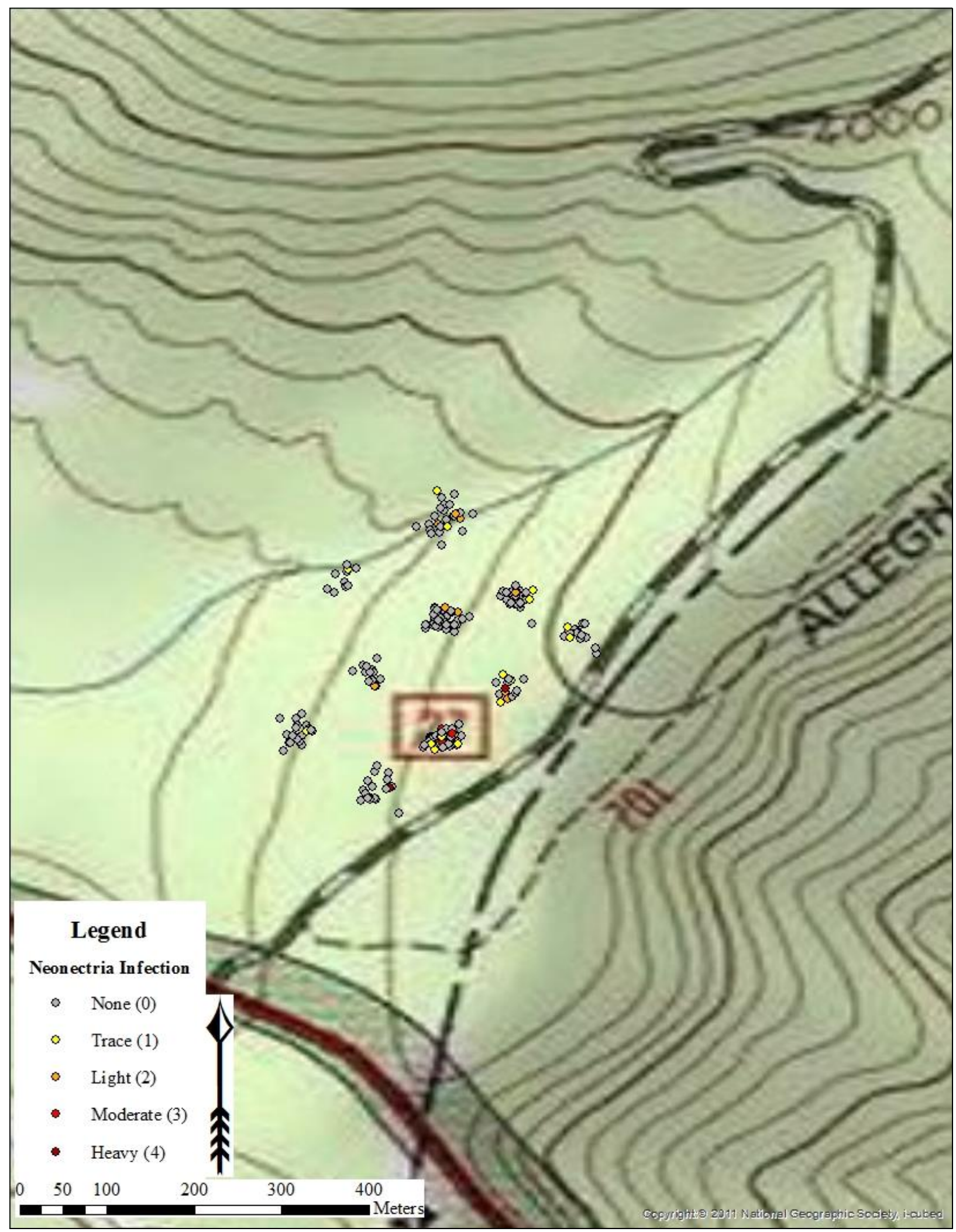

Figure 21: Distribution and Neonectria infection of Fagus grandifolia at Gaudineer Scenic Area site, Monongahela National Forest, Randolph County, WV (261 Fagus grandifolia sampled). 


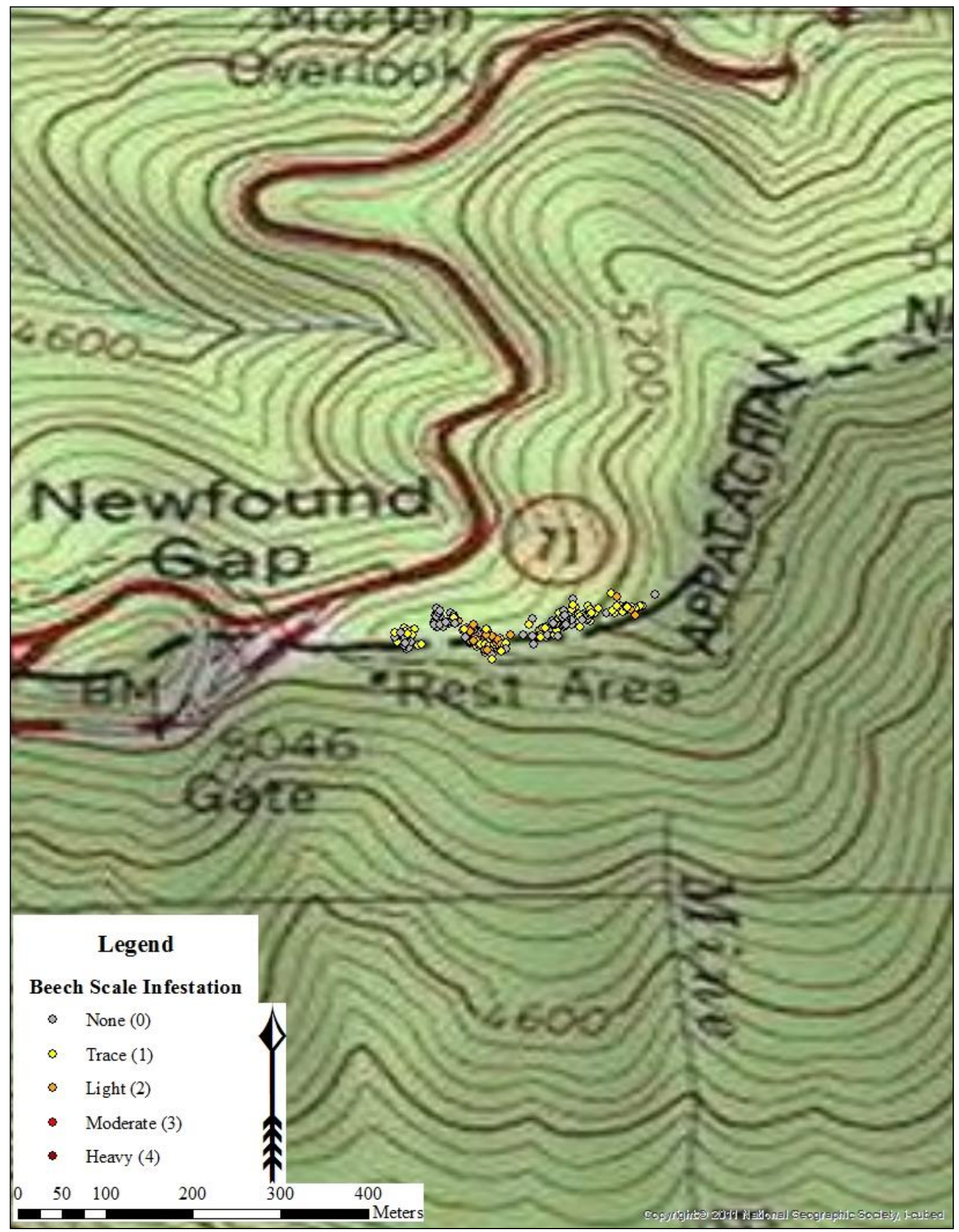

Figure 22: Distribution and Cryptococcus infestation of Fagus grandifolia at Great Smoky Mountains National Park site, Sevier County, TN (251 Fagus grandifolia sampled). 


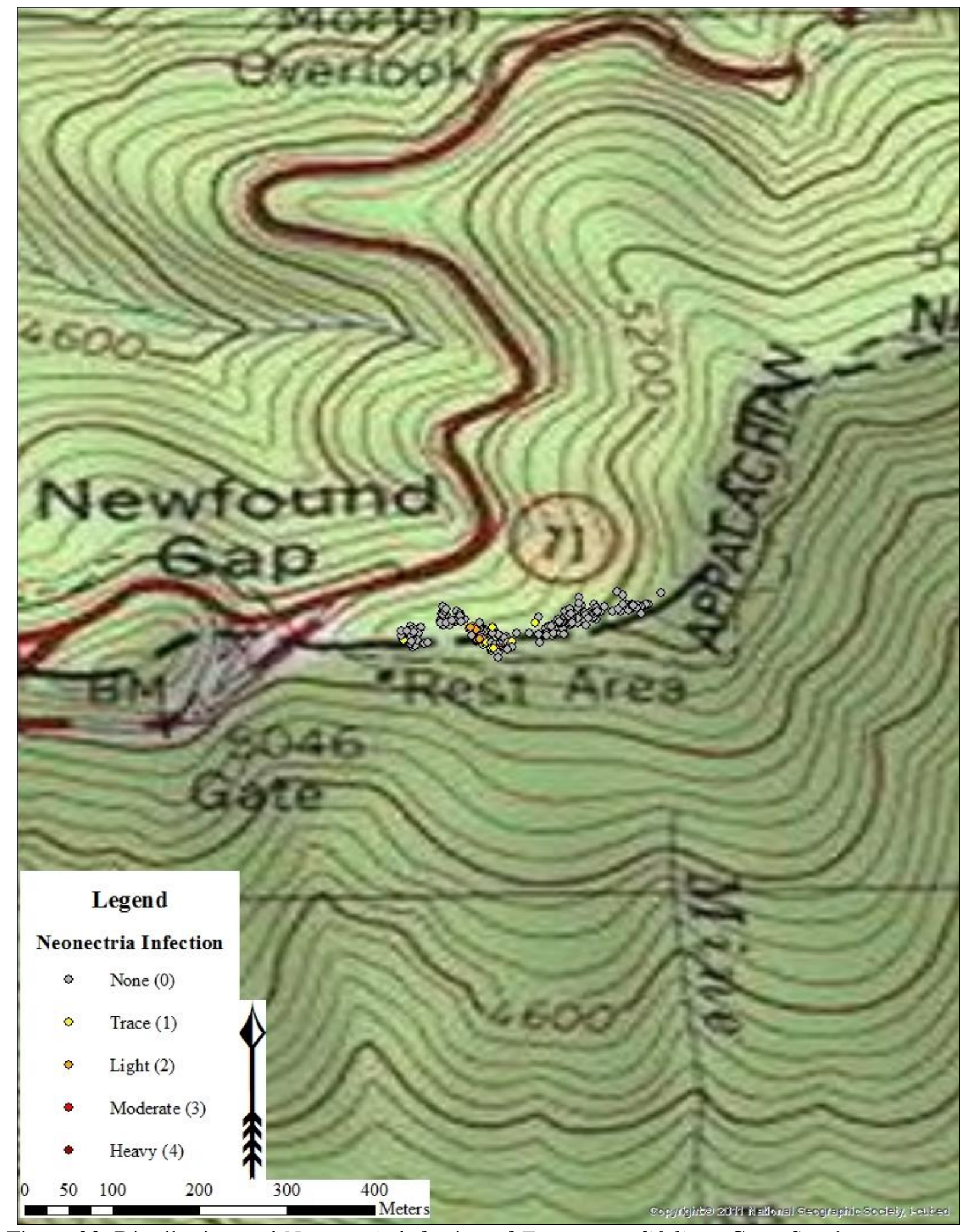

Figure 23: Distribution and Neonectria infection of Fagus grandifolia at Great Smoky Mountains National Park site, Sevier County, TN (251 Fagus grandifolia sampled). 


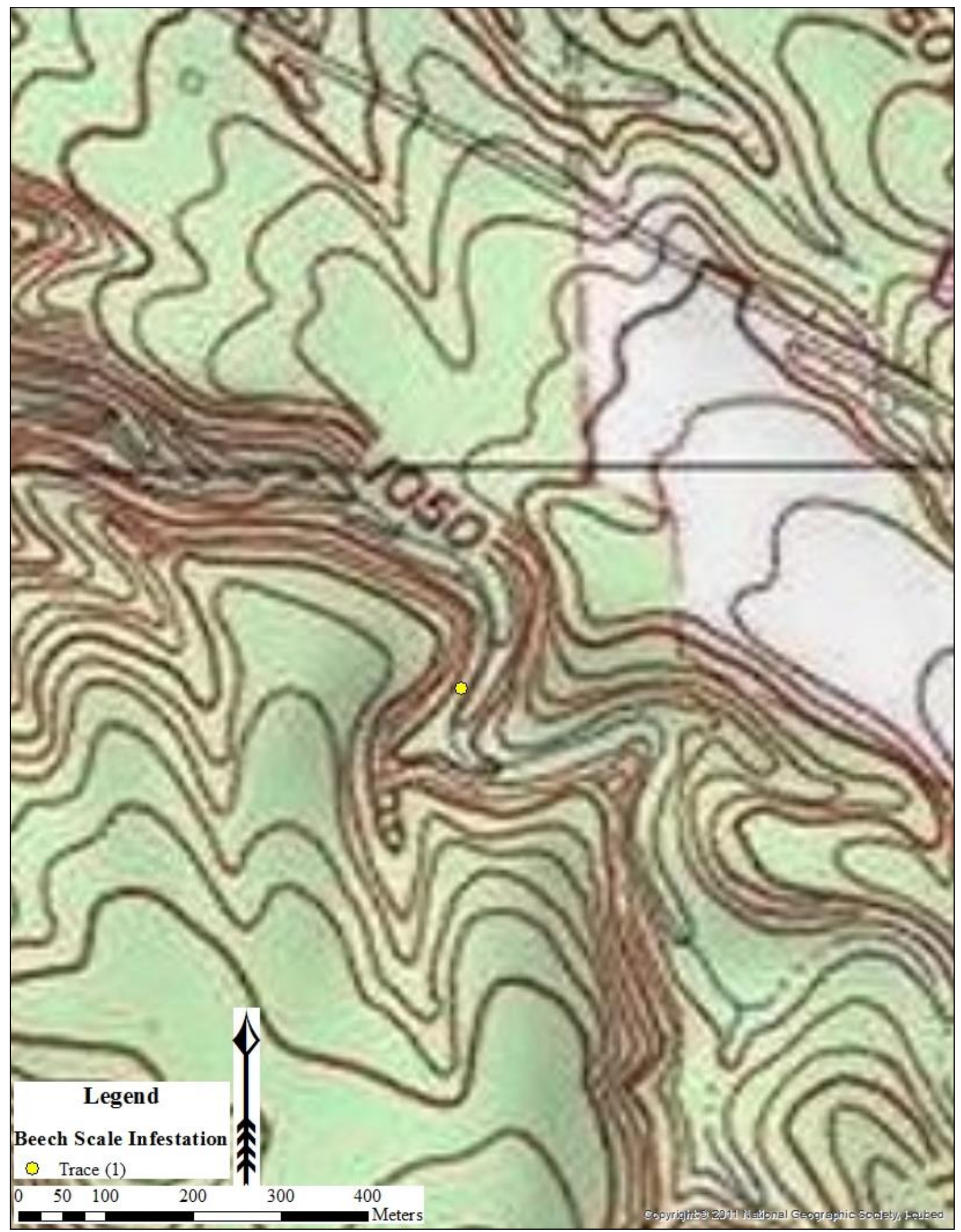

Figure 24: Distribution and Cryptococcus infestation of Fagus grandifolia at Holden Arboretum site, Geauga County, OH (94 Fagus grandifolia sampled). 


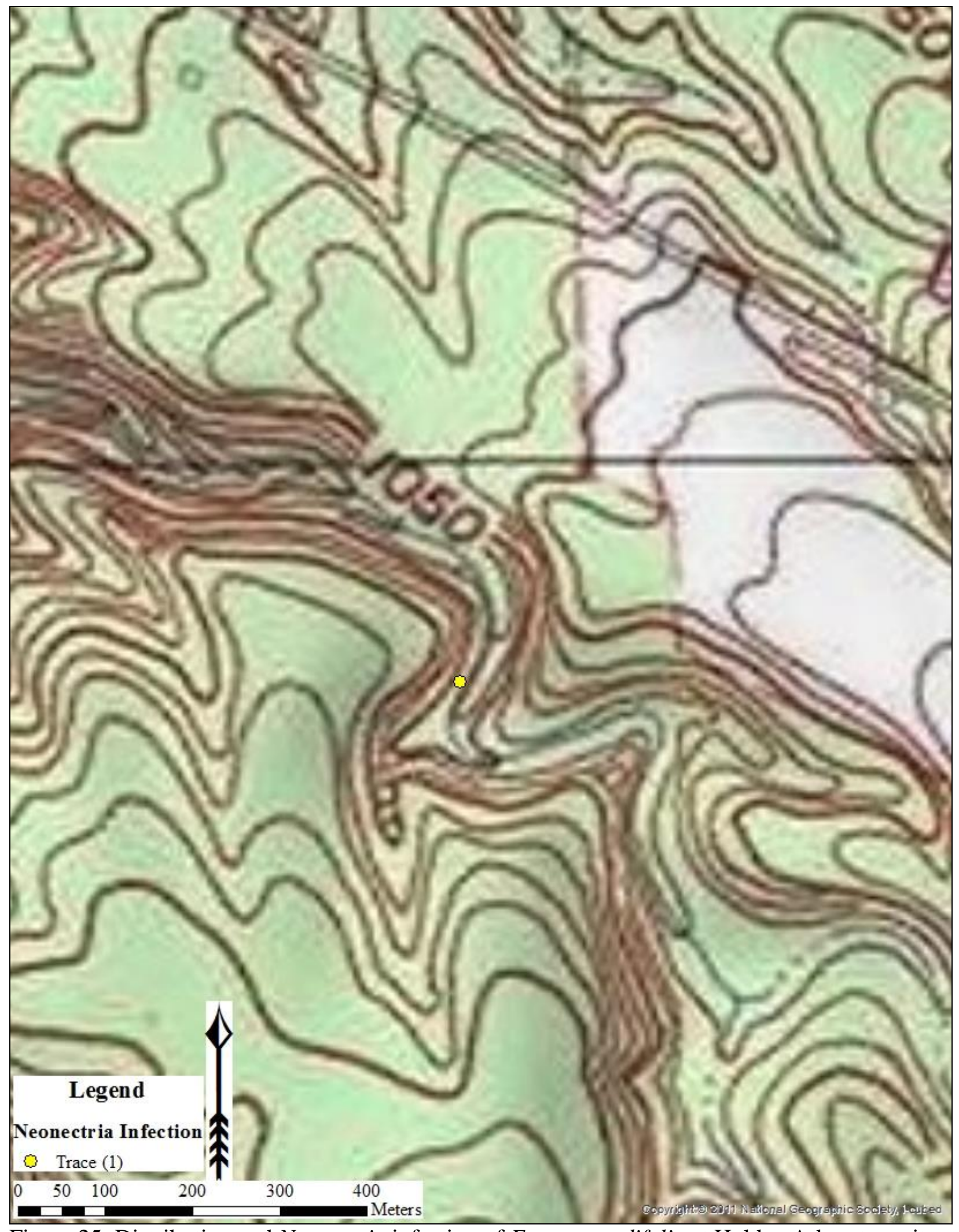

Figure 25: Distribution and Neonectria infection of Fagus grandifolia at Holden Arboretum site, Geauga County, $\mathrm{OH}$ (94 Fagus grandifolia sampled). 


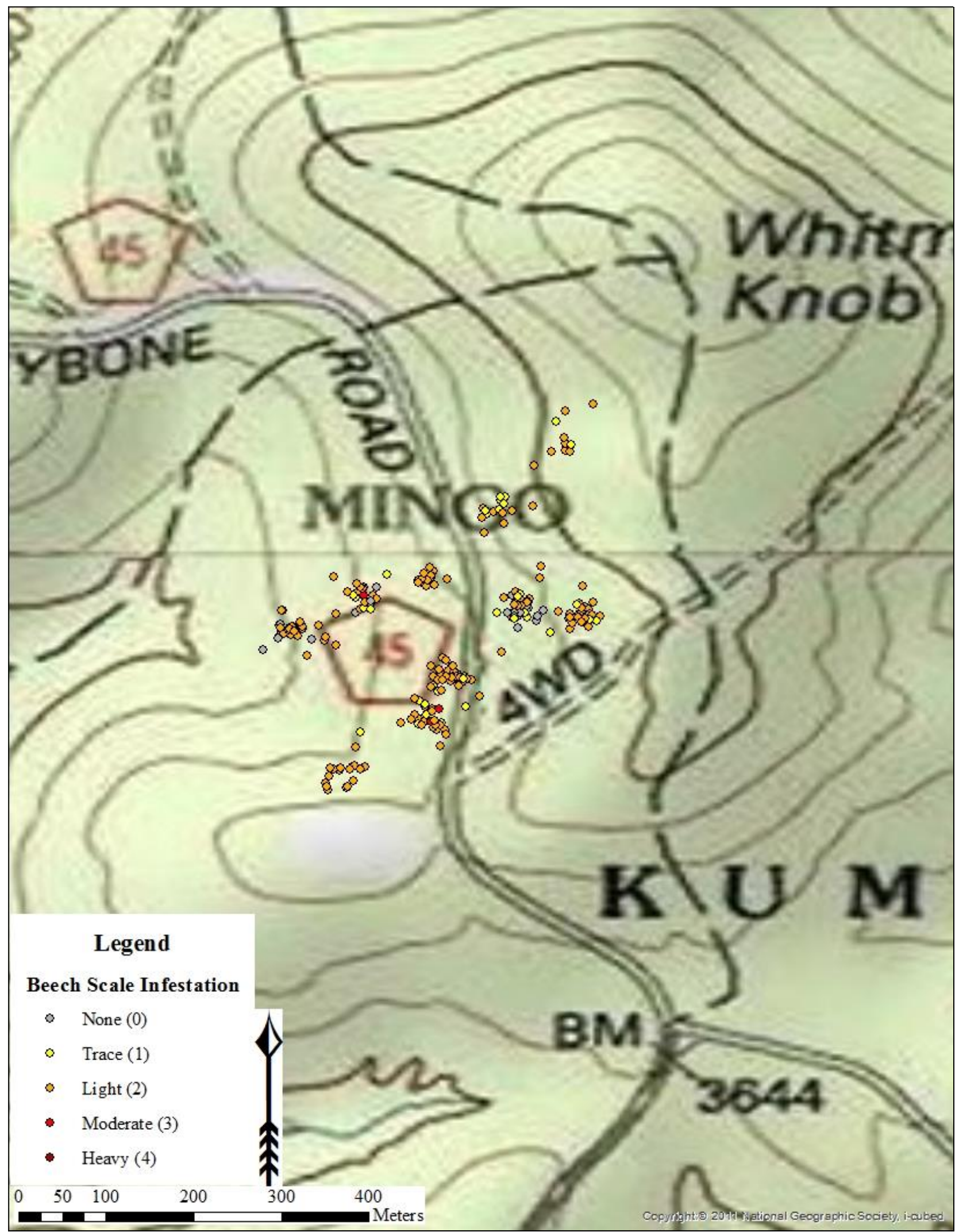

Figure 26: Distribution and Cryptococcus infestation of Fagus grandifolia at Kumbrabow State Forest site, Randolph County, WV (293 Fagus grandifolia sampled). 


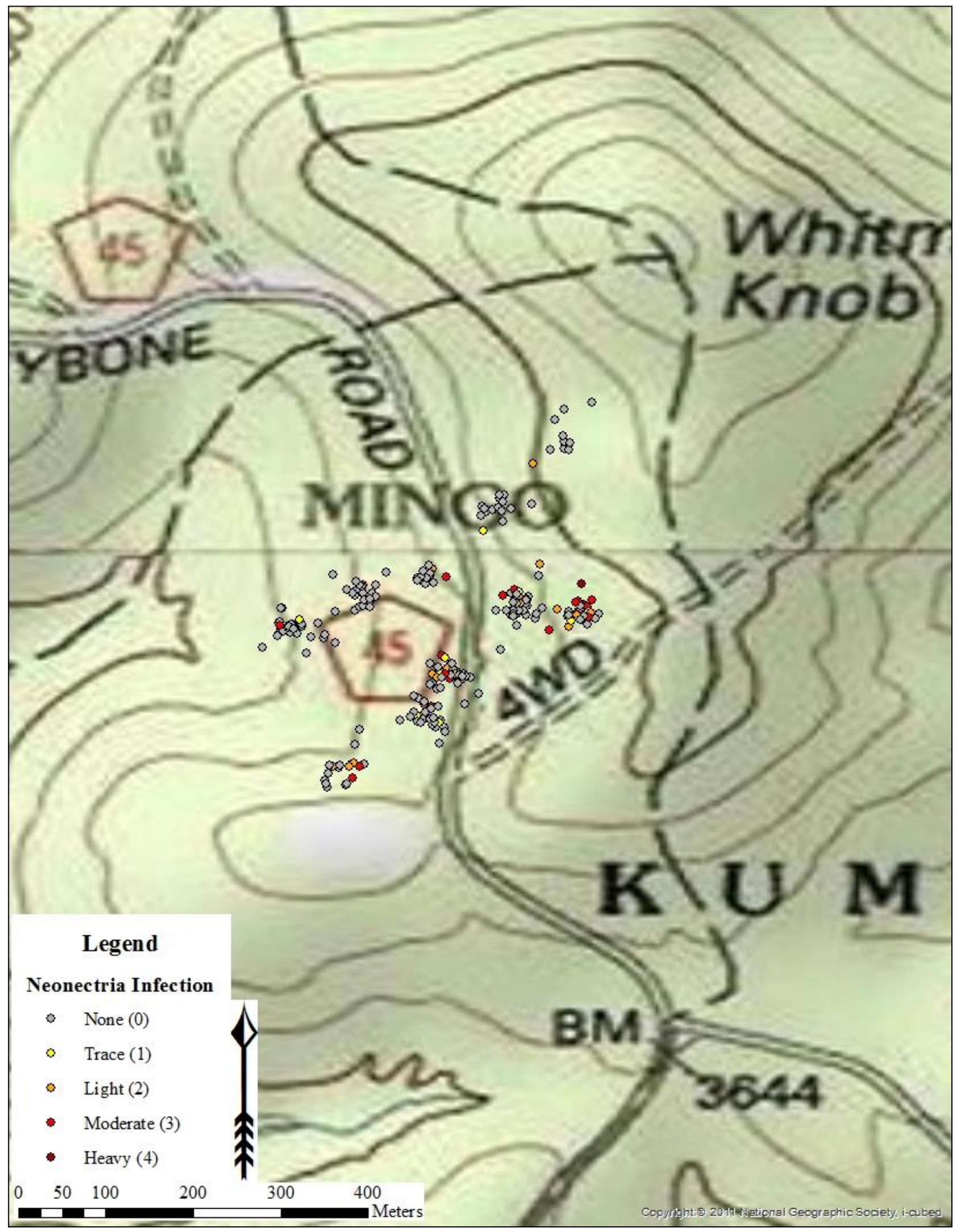

Figure 27: Distribution and Neonectria infection of Fagus grandifolia at Kumbrabow State Forest site, Randolph County, WV (293 Fagus grandifolia sampled). 


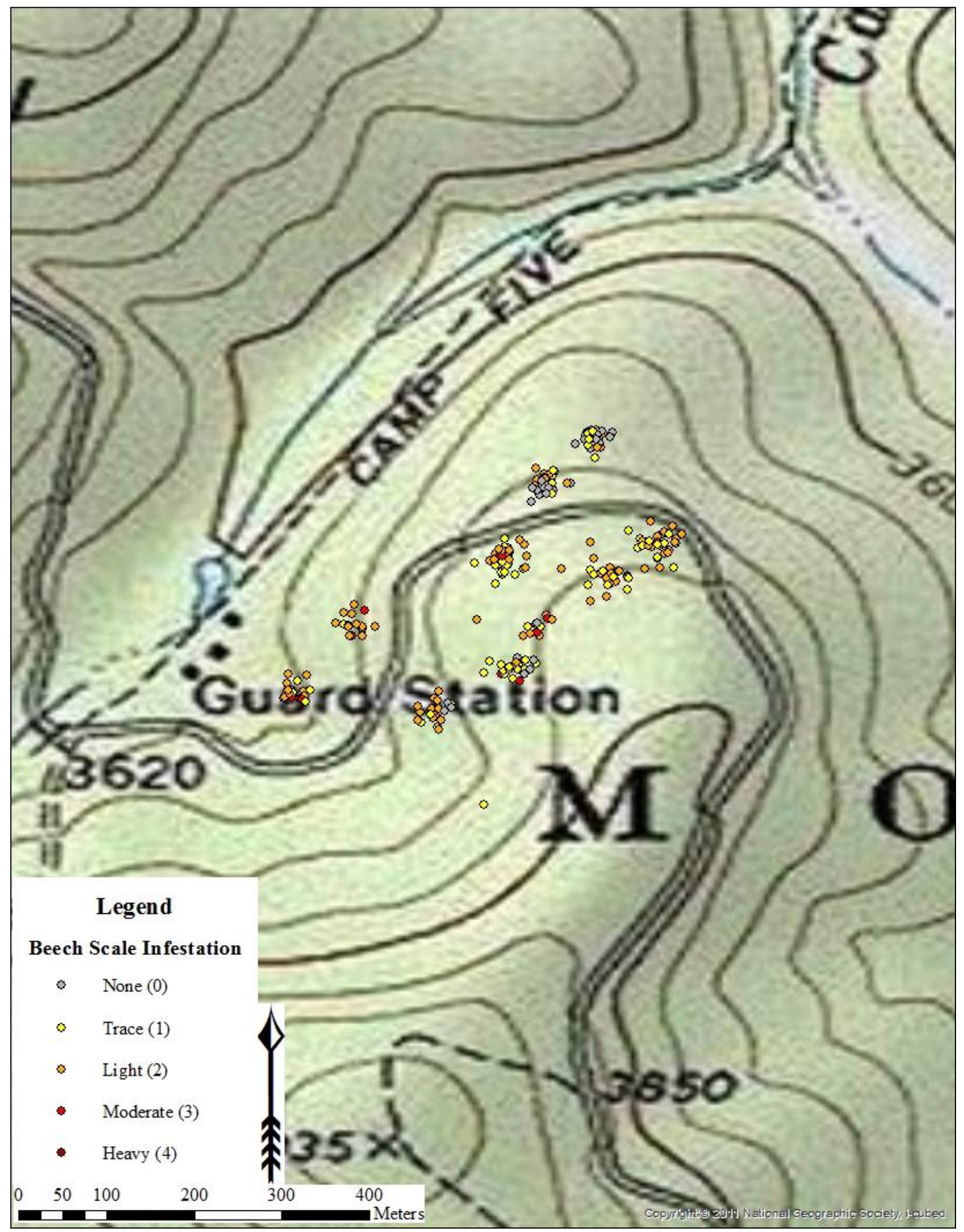

Figure 28: Distribution and Cryptococcus infestation of Fagus grandifolia at Middle Mountain site, Monongahela National Forest, Randolph County, WV (251 Fagus grandifolia sampled). 


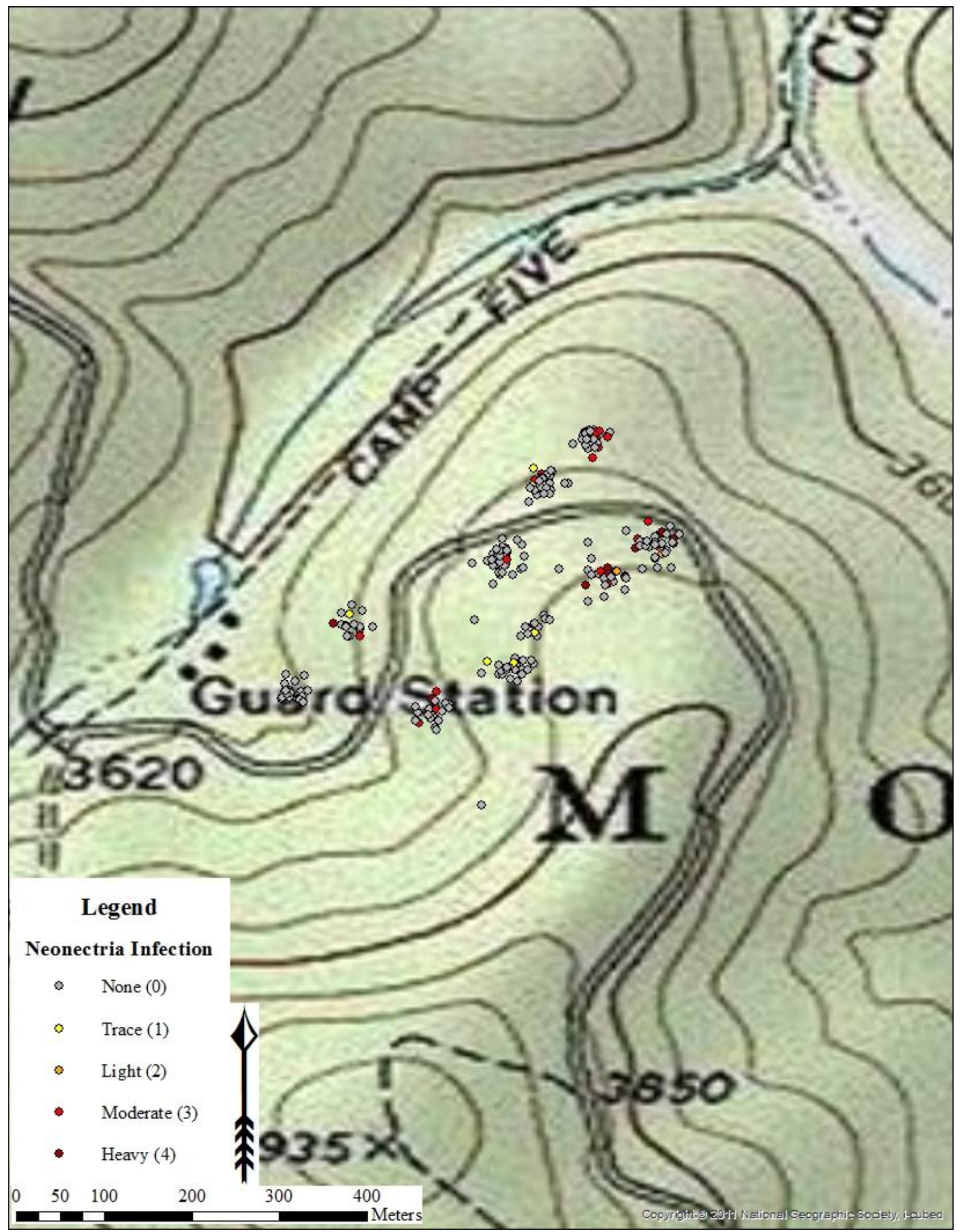

Figure 29: Distribution and Neonectria infection of Fagus grandifolia at Middle Mountain site, Monongahela National Forest, Randolph County, WV (251 Fagus grandifolia sampled). 


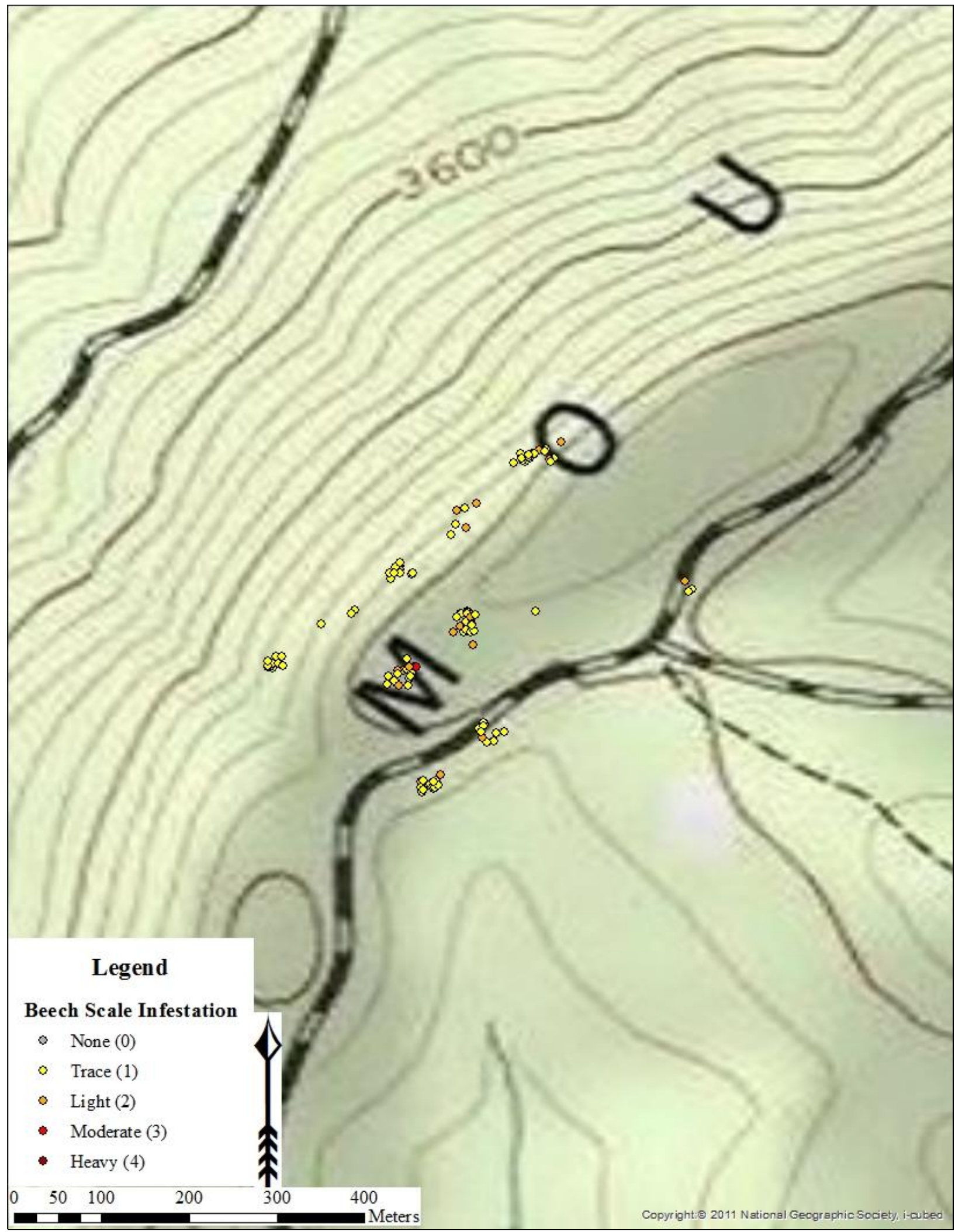

Figure 30: Distribution and Cryptococcus infestation of Fagus grandifolia at Shaver's Fork Recreation Area site, Monongahela National, Forest Randolph County, WV (156 Fagus grandifolia sampled). 


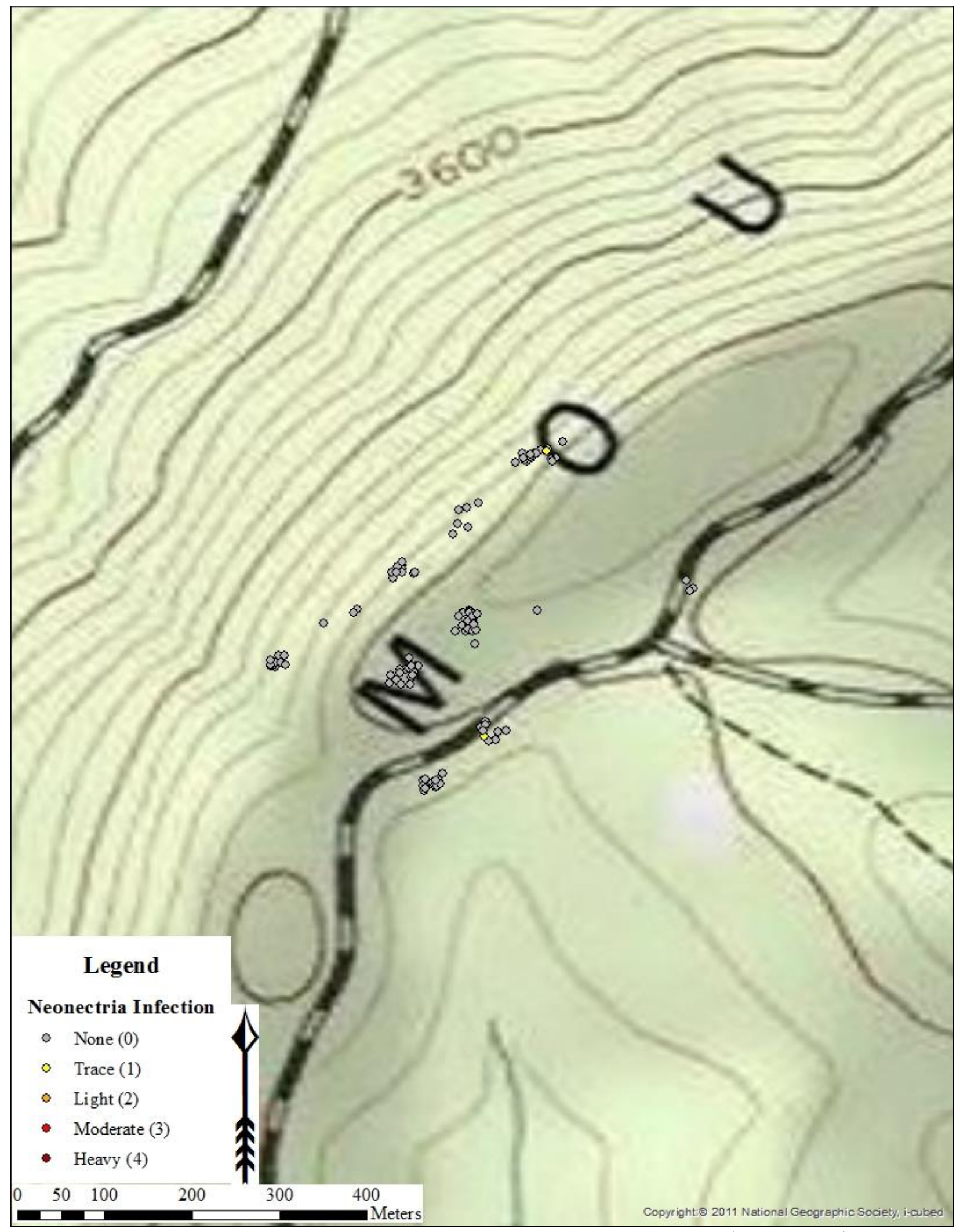

Figure 31: Distribution and Neonectria infection of Fagus grandifolia at Shaver's Fork Recreation Area site, Monongahela National, Forest Randolph County, WV (156 Fagus grandifolia sampled). 


\title{
Appendix 2: Quick Reference Guide Cryptococcus Categories:
}

\section{Cryptococcus Category 1}

\author{
, Trace scale population \\ , Tree initially looks clean but scale(s) evident upon close \\ inspection \\ , Hands lens may be needed to confirm
}

Remember: each category is a range of affects represented by the images on the other side

\begin{tabular}{|c|c|}
\hline Weak 1 & Moderate 1 \\
\hline Moderate 1 & Strong 1 \\
& \\
\hline
\end{tabular}

\section{Cryptococcus Category 2}

, Scales clearly evident from short distance

, Scales singular and uniformly dispersed or in scattered clusters

, Majority of stem still clean of scales

Remember: each category is a range of affects represented by the images on the other side

\begin{tabular}{|c|c|}
\hline Weak 2 & Moderate 2 \\
\hline Moderate 2 & Strong 2 \\
\hline
\end{tabular}
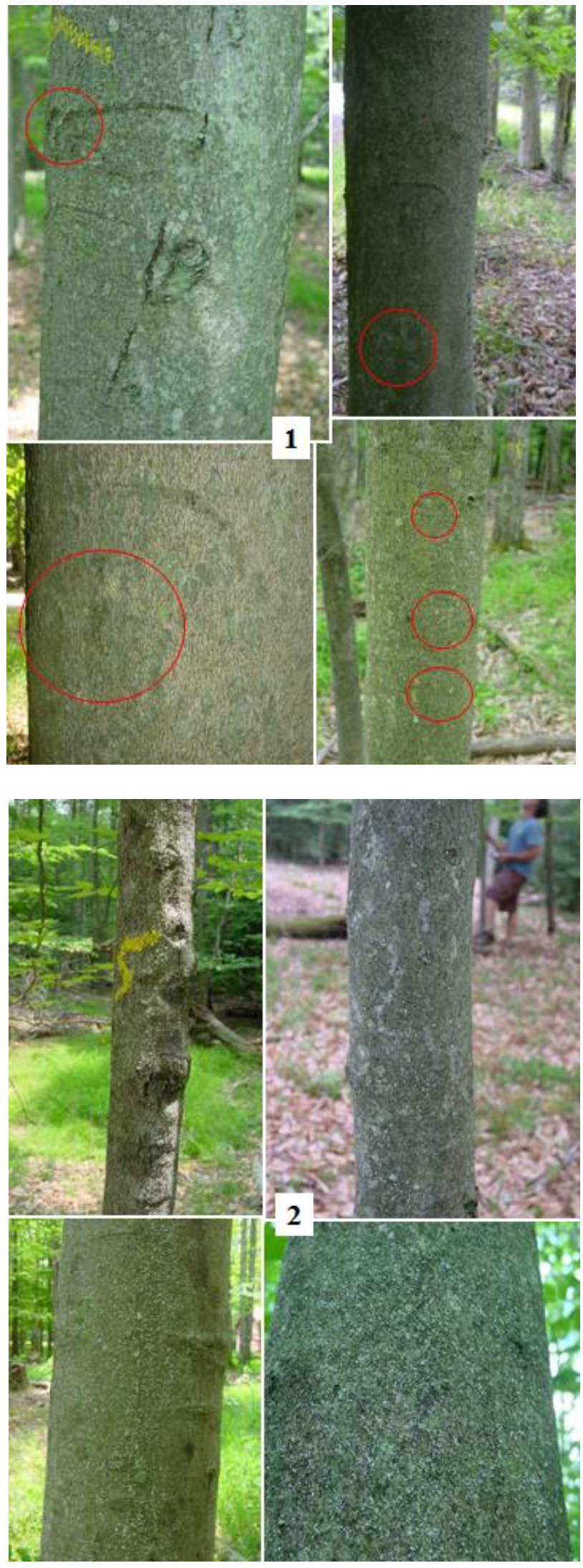


\section{Cryptococcus Category 3}

, Scales clearly evident from short distance

2 Scales singular and uniformly dispersed all over stem AND in scattered clusters..

Many clusters of scales along stem

Majority of stem likely clean of scales but may not be

Remember: each category is a range of affects represented by the images on the other side

\begin{tabular}{|c|c|}
\hline Weak 3 & Moderate 3 \\
\hline Moderate 3 & Strong 3 \\
\hline
\end{tabular}

\section{Cryptococcus Category 4}

, Scales clearly evident from short distance

, Scales in large clusters all over stem

, Majority of stem likely infested by scales but may not be

Remember: each category is a range of affects represented by the images on the other side

\begin{tabular}{|c|c|}
\hline Weak 4 & Moderate 4 \\
\hline Moderate 4 & Strong 4 \\
\hline
\end{tabular}
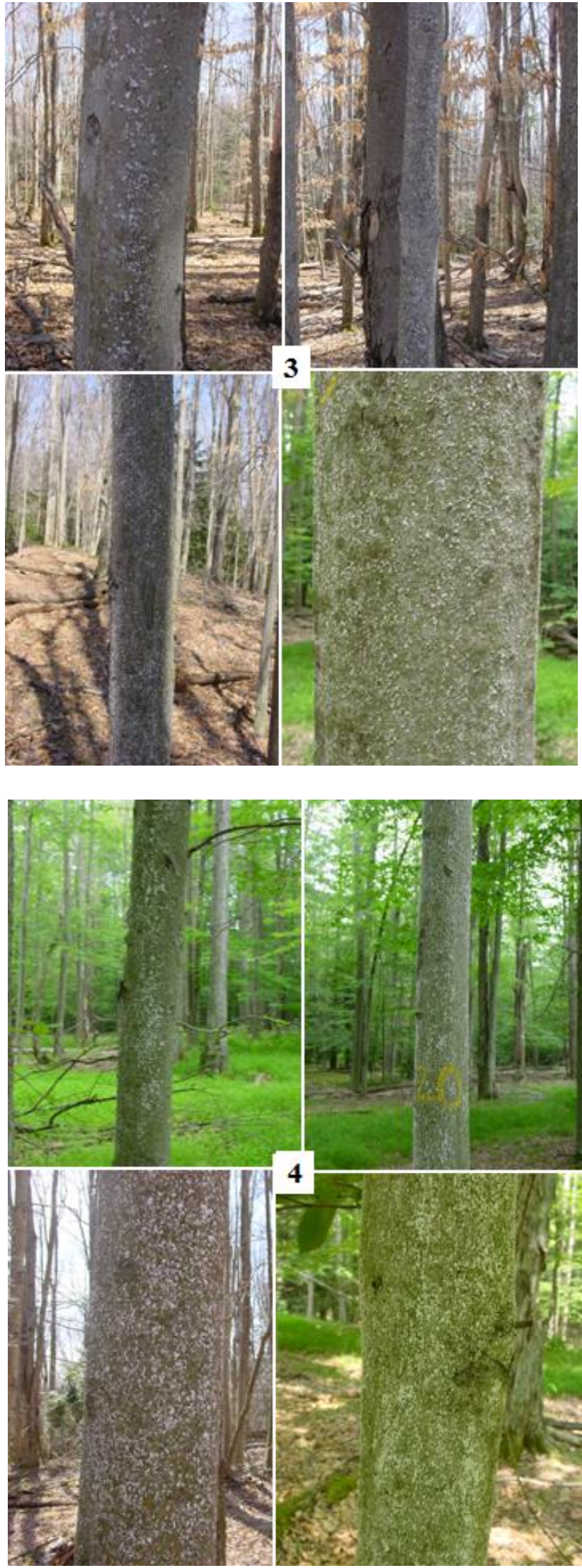


\title{
Neonectria Categories:
}

\author{
Neonectria Category 1 \\ , Trace Neonectria population \\ , Tree initially looks clean but canker(s)/perithecia evident \\ upon close inspection \\ , Hands lens may be needed to confirm \\ Remember: each category is a range of affects \\ represented by the images on the other side

\begin{tabular}{|c|c|}
\hline Weak 1 & Moderate 1 \\
\hline Moderate 1 & Strong 1 \\
& \\
\hline
\end{tabular}

\section{Neonectria Category 2} \\ , Cankers/perithecia clearly evident from short distance \\ , Few scattered cankers or clusters of cankers \\ , Vast majority of stem still clean of cankers/perithecia
}

Remember: each category is a range of affects represented by the images on the other side

\begin{tabular}{|c|c|}
\hline Weak 2 & Moderate 2 \\
\hline Moderate 2 & Strong 2 \\
& \\
\hline
\end{tabular}
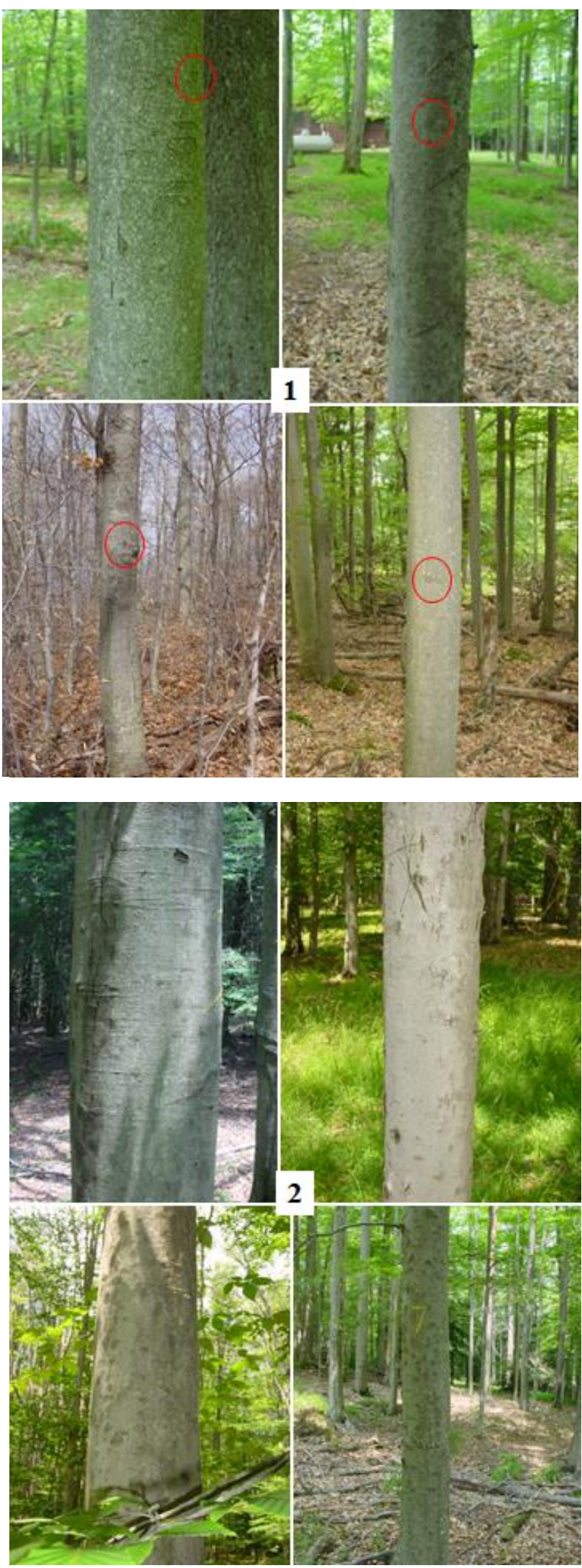


\section{Neonectria Category 3}

- Cankers/perithecia clearly evident from short distance

, Cankers litter large portion of stem

, Majority of stem likely cankered but may not be

, Streak (maybe 2) evident

, Perhaps small sections of bark peeling from stem

Remember: each category is a range of affects represented by the images on the other side

\begin{tabular}{|c|c|}
\hline Weak 3 & Moderate 3 \\
\hline Moderate 3 & Strong 3 \\
\hline
\end{tabular}

\section{Neonectria Category 4}

, Cankers/perithecia clearly evident from short distance

, Cankers affect nearly entire stem

, Multiple streaks on stem

, Large sections of bark peeling from stem

, Tree dead????

Remember: each category is a range of affects represented by the images on the other side

\begin{tabular}{|c|c|}
\hline Weak 4 & Moderate 4 \\
\hline Moderate 4 & Strong 4 \\
\hline
\end{tabular}
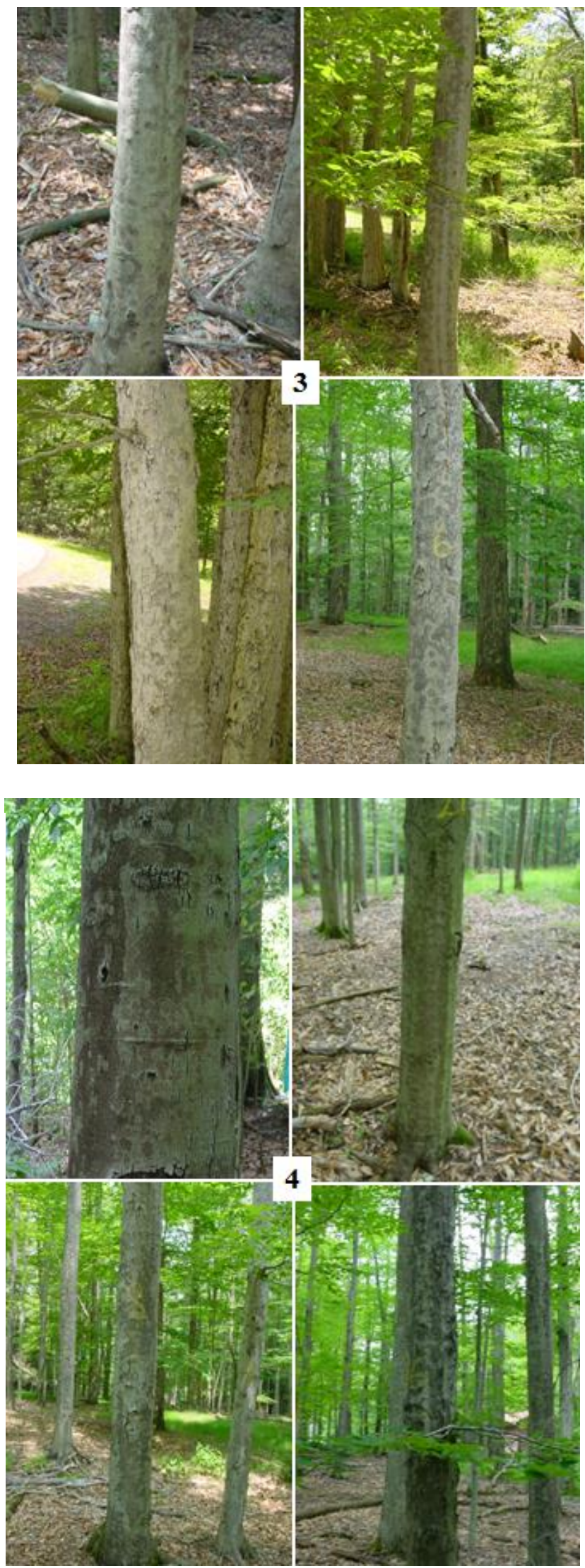


\section{Appendix 3: Parameters Recorded on Plots and Correlations}

Table 1: Parameters measured in the field.

\begin{tabular}{|c|c|}
\hline Data Category & Parameter \\
\hline Aspect & Azimuth degrees \\
\hline Basal area factor & BAF 10 \\
\hline Co-dominant species & Percent \\
\hline Crown density & Percent overhead area covered by canopy \\
\hline Decay of CWD & Mean of all decay ratings per plot(1-4) \\
\hline Decay of SCWD & Mean of all decay ratings per plot(1-4) \\
\hline Dominant species & Percent \\
\hline Elevation & Meters (m) \\
\hline Fagus grandifolia basal area/ha & Square meters $\left(\mathrm{m}^{2}\right)$ \\
\hline Fagus grandifolia mean DBH & Centimeters $(\mathrm{cm})$ \\
\hline Fagus grandifolia mean height & Meters \\
\hline Fagus grandifolia proportion & Percent \\
\hline Fagus grandifolia/ ha & Total stems/ha \\
\hline Fagus grandifolia with blocky cankers & Percent \\
\hline Intermediate species & Percent \\
\hline Litter depth & Centimeters $(\mathrm{cm})$ \\
\hline Non-beech species basal area/ha & Square meters $\left(\mathrm{m}^{2}\right)$ \\
\hline Non-beech species mean DBH & Centimeters $(\mathrm{cm})$ \\
\hline Non-beech species mean height & Meters \\
\hline Non-beech species/ha & Total non-beech stems/ha \\
\hline Overall basal area/ha & Square meters $\left(\mathrm{m}^{2}\right)$ \\
\hline Overall mean DBH & Centimeters $(\mathrm{cm})$ \\
\hline Overall trees/ha & Total overall stems/ha \\
\hline Proportion of species comprising CWD & Percent \\
\hline Proportion of species comprising SCWD & Percent \\
\hline Slope & Percent \\
\hline Soil A hor & Centimete \\
\hline Soil B horizon thickness & Centimeters $(\mathrm{cm})$ \\
\hline Soil E horizon thickness & Centimeters $(\mathrm{cm})$ \\
\hline n thickness & Centimeters $(\mathrm{cm})$ \\
\hline Suppressed species & Percent \\
\hline Total species evenness (plots $+\mathrm{s}$ & Shannon-Wiener index*species richness \\
\hline Total species diversity (plots + subplots) & Shannon-Wiener index \\
\hline Tree species diversity (plots) & Shannon-Wiener index \\
\hline Tree species diversity (subplots) & Shannon-Wiener index \\
\hline Tree species evenness (plots) & Shannon-Wiener index*species richness \\
\hline Tree species evenness (subplots) & Shannon-Wiener index*species richness \\
\hline Volume coarse woody debris $(\mathrm{CV}$ & Cubic meters $\left(\mathrm{m}^{3} / \mathrm{ha}\right)$ \\
\hline Volume standing coarse woody debris (SCWD) & Cubic meters $\left(\mathrm{m}^{3} / \mathrm{ha}\right)$ \\
\hline
\end{tabular}

Table 2: Parameters obtained from NOAA and Soil Survey databases.

\begin{tabular}{l|l}
\hline \multicolumn{1}{c|}{ Parameter } & \multicolumn{1}{c}{ Unit } \\
\hline Annual frost-free days & Days per year \\
Annual growing degree days & Annual total \\
Clay component of soil & Percent \\
Depth to water table & Centimeters $(\mathrm{cm})$ below surface \\
Depth to fragipan & Centimeters $(\mathrm{cm})$ below surface \\
Field capacity & Centimeters $(\mathrm{cm})$ \\
Mean annual precipitation & Centimeters $(\mathrm{cm})$ \\
Mean annual temperature & Degrees Celsius \\
Prevailing wind & Azimuth \\
Sand component of soil & Percent \\
Silt component of soil & Percent \\
Wind speed & $\mathrm{km} / \mathrm{hr}$ \\
\hline
\end{tabular}




\section{Appendix 4: Correlation, PCA, and Regression Data}

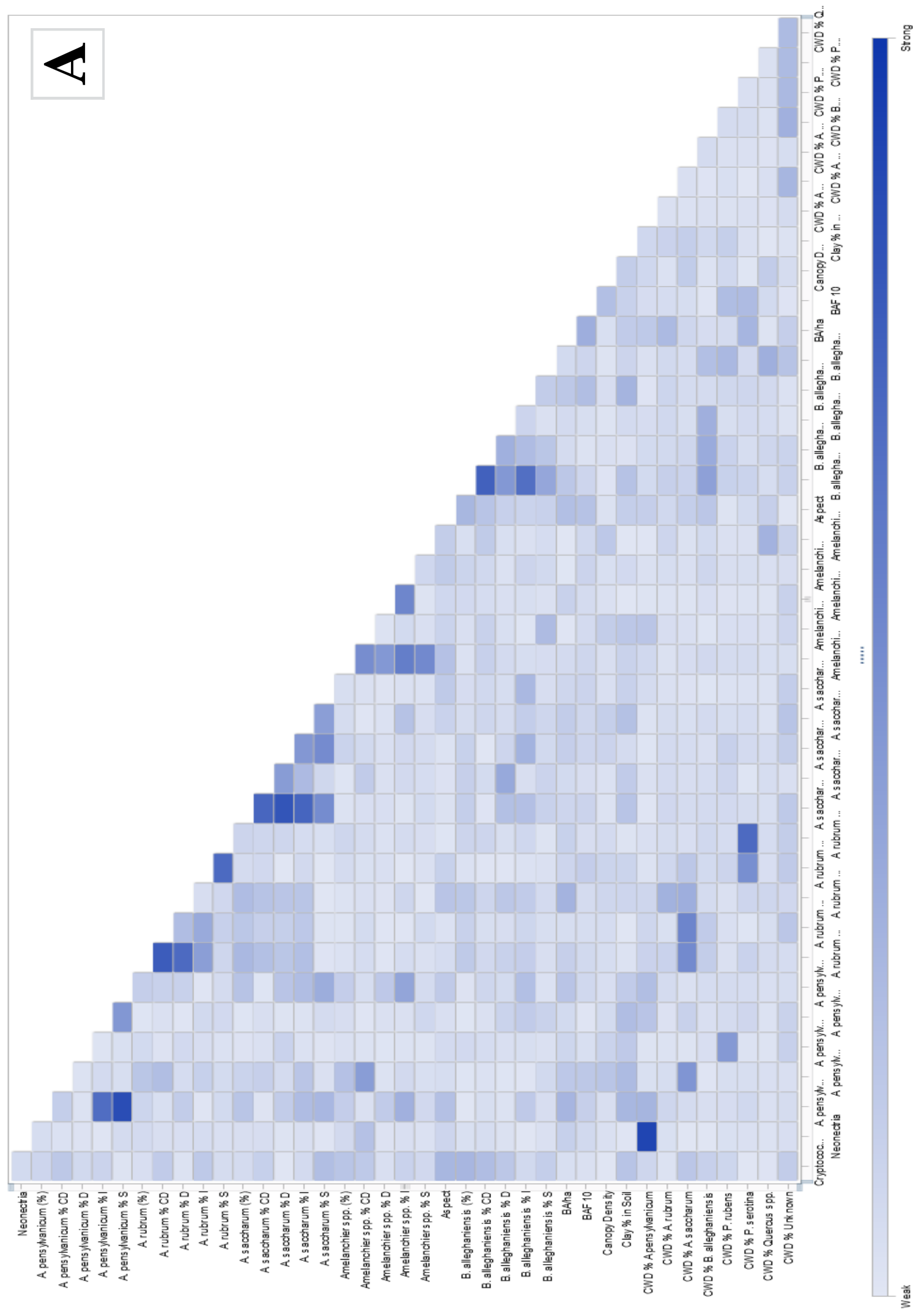




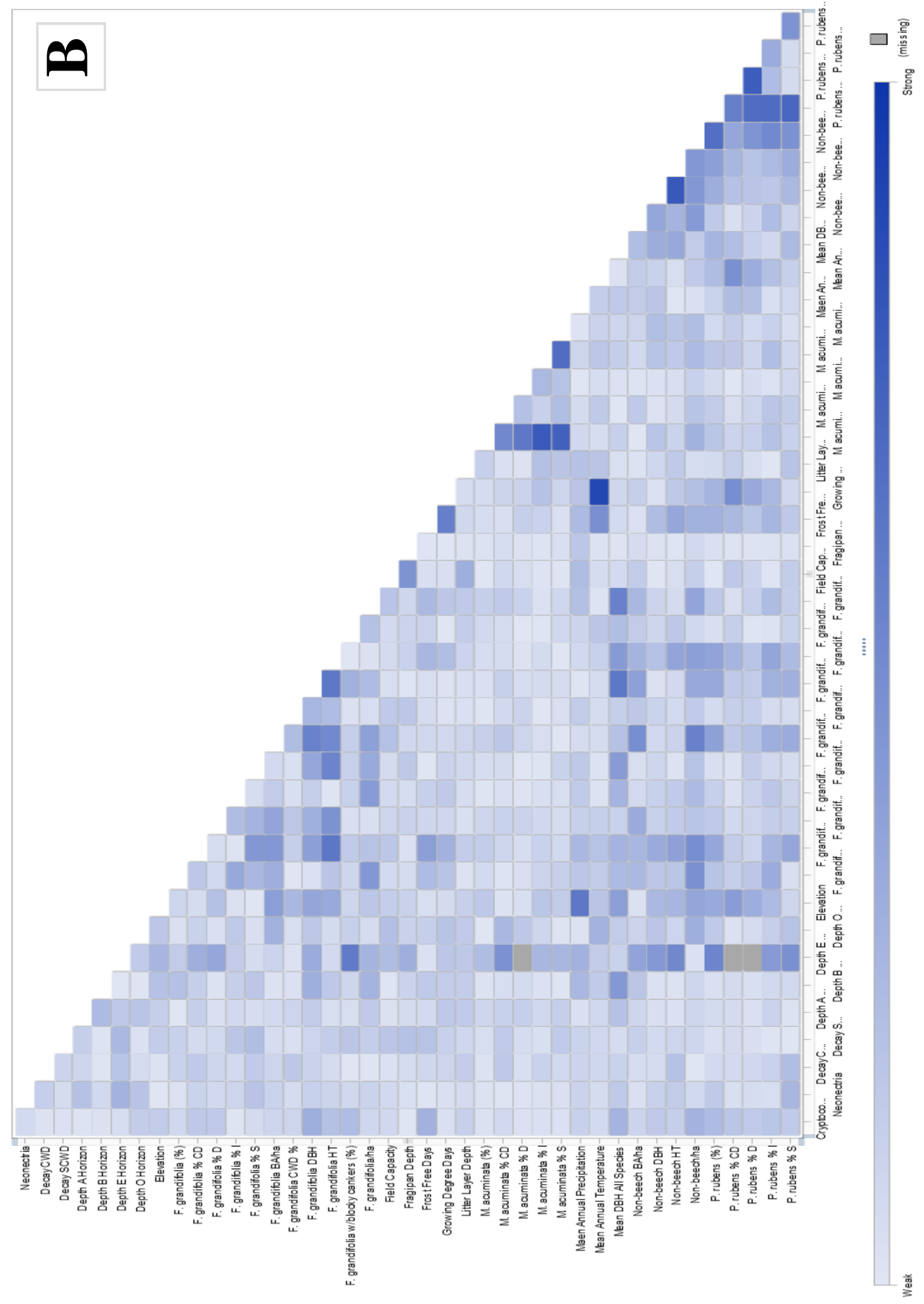




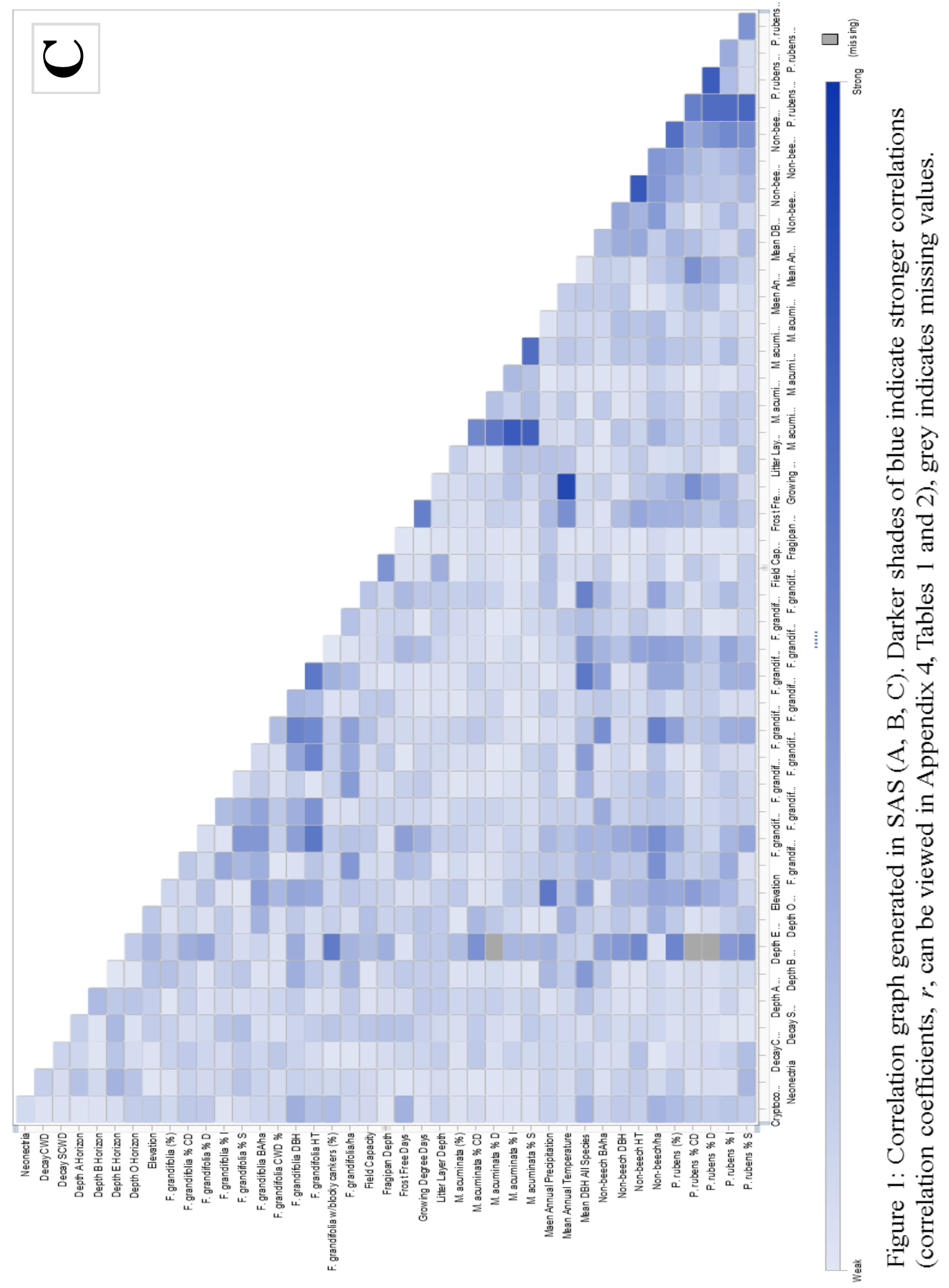


Table 1: Parameters used to build latent variables identified by PCA for regression, correlations with Cryptococcus infestation and Neonectria infection, and transformations.

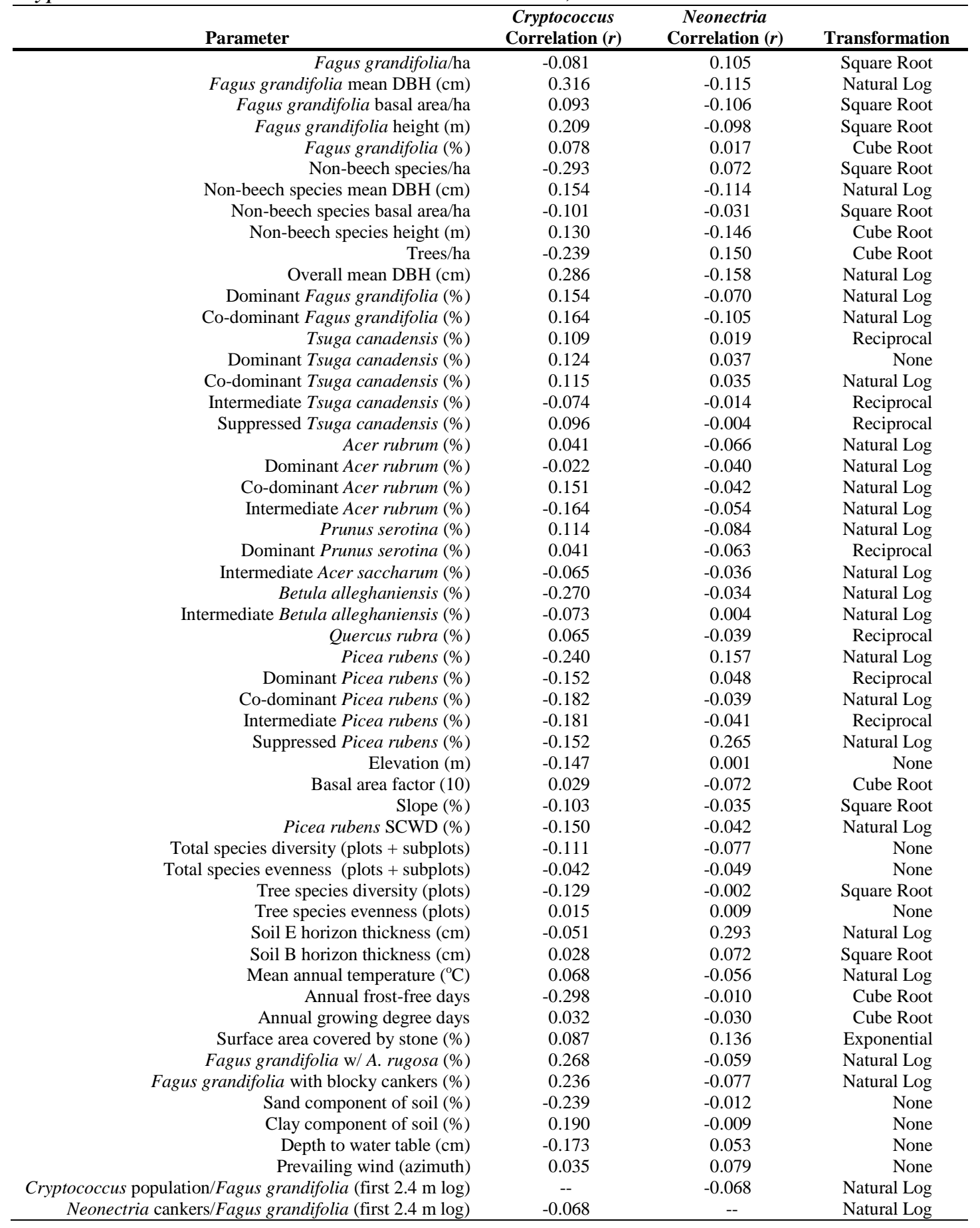


Table 2: Parameters and their correlations with Cryptococcus infestation and Neonectria infection.

\begin{tabular}{|c|c|c|}
\hline Parameter & $\begin{array}{c}\text { Cryptococcus } \\
\text { Correlation }(r)\end{array}$ & $\begin{array}{c}\text { Neonectria } \\
\text { Correlation }(r)\end{array}$ \\
\hline Overall basal area/ha & -0.039 & -0.125 \\
\hline Intermediate Fagus grandifolia $(\%)$ & 0.008 & -0.094 \\
\hline Suppressed Fagus grandifolia (\%) & -0.061 & 0.194 \\
\hline Suppressed Acer rubrum (\%) & 0.056 & -0.038 \\
\hline Co-dominant Prunus serotina (\%) & 0.081 & -0.074 \\
\hline Intermediate Prunus serotina (\%) & 0.090 & -0.026 \\
\hline Suppressed Prunus serotina (\%) & 0.050 & -0.016 \\
\hline Magnolia acuminata $(\%)$ & -0.023 & -0.022 \\
\hline Dominant Magnolia acuminata $(\%)$ & 0.027 & -0.014 \\
\hline Co-dominant Magnolia acuminata (\%) & -0.071 & 0.009 \\
\hline Intermediate Magnolia acuminata (\%) & 0.032 & -0.028 \\
\hline Suppressed Magnolia acuminata (\%) & -0.027 & -0.031 \\
\hline Acer saccharum (\%) & -0.061 & -0.042 \\
\hline Dominant Acer saccharum (\%) & -0.004 & -0.015 \\
\hline Co-dominant Acer saccharum (\%) & -0.125 & -0.047 \\
\hline Suppressed Acer saccharum (\%) & 0.226 & -0.008 \\
\hline Dominant Betula alleghaniensis (\%) & -0.175 & -0.028 \\
\hline Co-dominant Betula alleghaniensis (\%) & -0.228 & -0.048 \\
\hline Suppressed Betula alleghaniensis (\%) & -0.134 & -0.031 \\
\hline Amelanchier spp. (\%) & -0.185 & 0.070 \\
\hline Dominant Amelanchier spp. (\%) & -0.037 & -0.018 \\
\hline Co-dominant Amelanchier spp. (\%) & -0.163 & 0.208 \\
\hline Intermediate Amelanchier spp. (\%) & -0.111 & -0.035 \\
\hline Suppressed Amelanchier spp. (\%) & -0.075 & -0.028 \\
\hline Acer pensylvanicum $(\%)$ & -0.091 & 0.047 \\
\hline Dominant Acer pensylvanicum (\%) & -0.073 & -0.019 \\
\hline Co-dominant Acer pensylvanicum (\%) & -0.170 & -0.025 \\
\hline Intermediate Acer pensylvanicum (\%) & 0.103 & 0.006 \\
\hline Suppressed Acer pensylvanicum (\%) & -0.015 & 0.059 \\
\hline Dominant Quercus rubra $(\%)$ & 0.056 & -0.026 \\
\hline Co-dominant Quercus rubra (\%) & 0.043 & -0.031 \\
\hline Intermediate Quercus rubra (\%) & -0.007 & -0.015 \\
\hline Canopy density (\% overhead area coverage) & -0.001 & 0.032 \\
\hline Aspect (azimuth) & -0.266 & 0.094 \\
\hline Litter layer depth $(\mathrm{cm})$ & -0.122 & -0.059 \\
\hline Volume coarse woody debris $\left(\mathrm{m}^{3} / \mathrm{ha}\right)$ & -0.071 & -0.011 \\
\hline Volume standing coarse woody debris $\left(\mathrm{m}^{3} / \mathrm{ha}\right)$ & 0.132 & 0.252 \\
\hline Decay CWD & -0.017 & 0.132 \\
\hline Decay SCWD & -0.025 & 0.053 \\
\hline Fagus grandifolia CWD (\%) & -0.094 & -0.052 \\
\hline Prunus serotina CWD (\%) & -0.003 & -0.032 \\
\hline Quercus spp. CWD (\%) & -0.013 & -0.022 \\
\hline Acer saccharum CWD (\%) & 0.178 & -0.001 \\
\hline Acer pensylvanicum CWD (\%) & -0.087 & 0.912 \\
\hline Acer rubrum CWD (\%) & -0.020 & -0.034 \\
\hline Picea rubens CWD (\%) & -0.090 & -0.034 \\
\hline Unknown CWD (\%) & 0.147 & 0.040 \\
\hline Betula alleghaniensis CWD (\%) & -0.123 & -0.003 \\
\hline Fagus grandifolia SCWD (\%) & -0.055 & 0.105 \\
\hline Prunus serotina SCWD (\%) & 0.051 & -0.058 \\
\hline Quercus spp. SCWD (\%) & -0.013 & -0.033 \\
\hline Magnolia acuminata SCWD (\%) & -0.034 & -0.025 \\
\hline Acer rubrum SCWD (\%) & -0.001 & -0.040 \\
\hline Acer saccharum SCWD (\%) & 0.161 & -0.038 \\
\hline Acer pensylvanicum SCWD (\%) & 0.161 & -0.038 \\
\hline Unknown SCWD (\%) & 0.009 & -0.069 \\
\hline Betula alleghaniensis SCWD (\%) & 0.123 & 0.139 \\
\hline Diversity subplots & -0.016 & -0.161 \\
\hline Evenness subplots & -0.084 & -0.175 \\
\hline Soil O horizon thickness $(\mathrm{cm})$ & -0.139 & 0.193 \\
\hline Soil A horizon thickness (cm) & -0.014 & -0.205 \\
\hline Silt component of soil (\%) & 0.193 & 0.020 \\
\hline Mean annual precipitation $(\mathrm{cm})$ & -0.119 & -0.103 \\
\hline Depth to fragipan $(\mathrm{cm})$ & 0.002 & -0.033 \\
\hline Field capacity $(\mathrm{cm})$ & -0.080 & -0.069 \\
\hline Wind speed $(\mathrm{km} / \mathrm{hr})$ & -0.014 & -0.060 \\
\hline
\end{tabular}




\section{Appendix 5: DNA Sequencing Data}

Table 1: NCBI nucleotide blast results for sequences from a Neonectria fungus isolated from bark of Fagus grandifolia (query) and Neonectria faginata strain Nf24A1, Sequence ID: gbJQ868431.1 (subject).

\begin{tabular}{|c|c|c|c|c|c|}
\hline \multirow{2}{*}{\multicolumn{2}{|c|}{$\begin{array}{c}\text { Score } \\
917 \text { bits }(496)\end{array}$}} & \multirow{2}{*}{$\begin{array}{c}\text { Expect } \\
0.0\end{array}$} & \multirow{2}{*}{$\begin{array}{c}\text { Identities } \\
503 / 506(99 \%)\end{array}$} & \multicolumn{2}{|l|}{ Gaps } \\
\hline & & & & $2 / 506(0 \%)$ & \\
\hline Query & 4 & $\begin{array}{l}\text { CCTGATC } \\
|||||| \mid\end{array}$ & $\begin{array}{l}\text { EGAGGTCA-CCTT } \\
||||||||||||\end{array}$ & 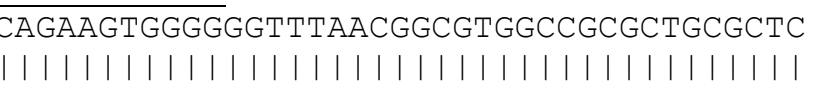 & 62 \\
\hline Sbjet & 505 & CCTGATC & CGAGGTCAACCTT" & CAGAAGTGGGGGGTTTAACGGCGTGGCCGCGCTGCGCTC & 446 \\
\hline Query & 63 & $\begin{array}{l}\text { CAGCGCG } \\
|||||| \mid\end{array}$ & $\begin{array}{l}\text { AGTGTTGCTACTA } \\
|||||||||||| \mid\end{array}$ & $\begin{array}{l}\text { GCGGAGGAAGCTGCAGCGAGACCGCCACTAGATTTGGGG } \\
|||||||||||||||||||||||||||||||||||||||||||||l|\end{array}$ & 122 \\
\hline Sbjet & 445 & CAGCGCG & AGTGTTGCTACTA & GCGGAGGAAGCTGCAGCGAGACCGCCACTAGATTTGGGG & 386 \\
\hline Query & 123 & $\begin{array}{l}\text { GACGGCC } \\
|||||| \mid\end{array}$ & $\begin{array}{l}\text { EGCCGCGGGGGGC } \\
||||||||||||||\end{array}$ & 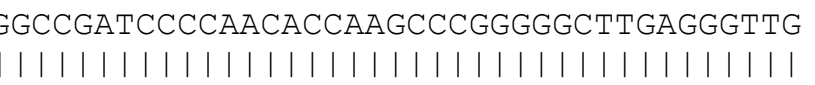 & 182 \\
\hline Sbjet & 385 & GACGGCC & EGCCGCGGGGGGC & GGCCGATCCCCAACACCAAGCCCGGGGGCTTGAGGGTTG & 326 \\
\hline Query & 183 & $\begin{array}{l}\text { AAATGAC } \\
|||||| \mid\end{array}$ & $\begin{array}{l}\text { GCTCGAACAGGCA } \\
|||||||||||| \mid\end{array}$ & 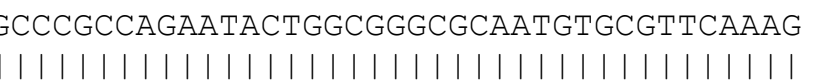 & 242 \\
\hline Sbjet & 325 & AAATGAC & GCTCGAACAGGCA & GCCCGCCAGAATACTGGCGGGCGCAATGTGCGTTCAAAG & 266 \\
\hline Query & 243 & $\begin{array}{l}\text { ATTCGAT } \\
|||||| \mid\end{array}$ & $\begin{array}{l}\text { GATTCACTGAATT } \\
|\|||||||||| \mid\end{array}$ & 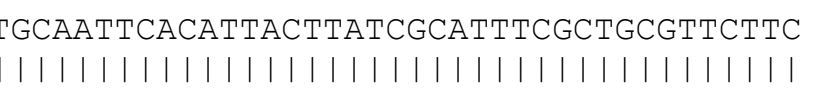 & 302 \\
\hline Sbjet & 265 & ATTCGAT & GATTCACTGAATT & TGCAATTCACATTACTTATCGCATTTCGCTGCGTTCTTC & 206 \\
\hline Query & 303 & $\begin{array}{l}\text { ATCGATG } \\
|||||| \mid\end{array}$ & $\begin{array}{l}\text { CCAGAACCAAGAG } \\
|||||||||||| \mid\end{array}$ & 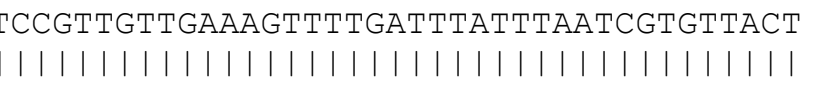 & 362 \\
\hline Sbjet & 205 & ATCGATG & CCAGAACCAAGAG & CCCGTTGTTGAAAGTTTTGATTTATTTAATCGTGTTACT & 146 \\
\hline Query & 363 & $\begin{array}{l}\text { CAGAAGA } \\
|||||| \mid\end{array}$ & $\begin{array}{l}\text { RACTGTAATAAAC } \\
|||||||||||| \mid\end{array}$ & 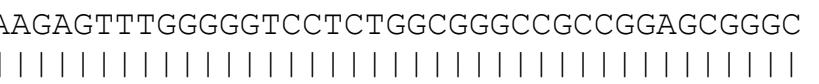 & 422 \\
\hline Sbjet & 145 & CAGAAGA & ГACTGTAATAAAC & AAGAGTTTGGGGGTCCTCTGGCGGGCCGCCGGAGCGGGC & 86 \\
\hline Query & 423 & $\begin{array}{l}\text { ACCGCCG } \\
|||||| \mid\end{array}$ & $\begin{array}{l}\text { AGGCAACGATAGG } \\
|||||||||||| \mid\end{array}$ & $\begin{array}{l}\text { ITGTTCACAGGGGTTTGGGAGTTGTAAACTCGATAATGA } \\
|||||||||||||||||||||||||||||||||||||| \mid)\end{array}$ & 482 \\
\hline Sbjct & 85 & ACCGCCG & AGGCAACGATAGG' & ITGTTCACAGGGGTTTGGGAGTTGTAAACTCGATAATGA & 26 \\
\hline Query & 483 & $\begin{array}{l}\text { TCCCTCC } \\
|||||| \mid\end{array}$ & $\begin{array}{l}\text { SCAGGTTCACCCT: } \\
||||||||||||\end{array}$ & $\begin{array}{ll}\text { IGGAA } & 508 \\
|\|| \mid & \end{array}$ & \\
\hline Sbjet & 25 & TCCCTCC & GCAGGTTCACC-T & GGAA 1 & \\
\hline
\end{tabular}


Table 2: NCBI nucleotide blast results for sequences from a Neonectria fungus isolated from bark of Fagus grandifolia (query) and Neonectria faginata strain Nf75A1, Sequence ID: gbJQ868435.1 (subject).

\begin{tabular}{|c|c|c|c|c|c|}
\hline Sco & & Expect & Identities & Gaps & \\
\hline 893 bit & $(483)$ & 0.0 & 486/487(99\%) & $1 / 487(0 \%)$ & \\
\hline Query & 7 & $\begin{array}{l}\mathrm{AACCCCT} \\
|||||| \mid\end{array}$ & $\begin{array}{l}\text { GTG-ACATACCTA } \\
|||||||||||| \mid\end{array}$ & $\begin{array}{l}\text { CGTTGCCTCGGCGGTGCCCGCTCCGGCGGCCCGCCAGAG } \\
|l| l|l| l|l| l|l| l|l| l|l| l|l| l|l| l|l| l|l|\end{array}$ & 65 \\
\hline Sbjet & 40 & AACCCCT & GTGAACATACCTA & CGTTGCCTCGGCGGTGCCCGCTCCGGCGGCCCGCCAGAG & 99 \\
\hline Query & 66 & $\begin{array}{l}\text { GACCCCC } \\
|||||| \mid\end{array}$ & $\begin{array}{l}\text { AAACTCTTTGTTT } \\
|||||||||||| \mid\end{array}$ & 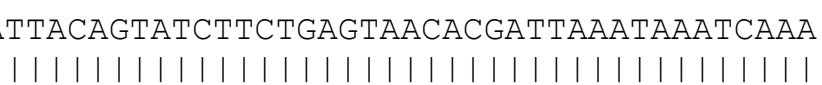 & 125 \\
\hline Sbjet & 100 & GACCCCO & AAACTCTTTGTTT & TTACAGTATCTTCTGAGTAACACGATTAAATAAATCAAA & 159 \\
\hline Query & 126 & ACTTTCA & ACAACGGATCTCT & 'GGTTCTGGCATCGATGAAGAACGCAGCGAAATGCGATAA & 185 \\
\hline Sbjet & 160 & ACTTTCA & ACAACGGATCTCT & GGTTCTGGCATCGATGAAGAACGCAGCGAAATGCGATAA & 219 \\
\hline Query & 186 & $\begin{array}{l}\text { GTAATGT } \\
|||||| \mid\end{array}$ & $\begin{array}{l}\text { GAATTGCAGAATT } \\
|||||||||||| \mid\end{array}$ & 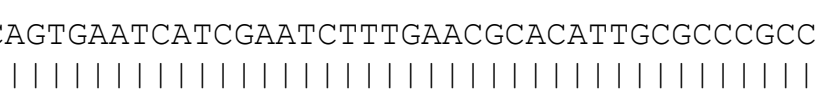 & 245 \\
\hline Sbjet & 220 & GTAATGT & GAATTGCAGAATT & AGTGAATCATCGAATCTTTGAACGCACATTGCGCCCGCC & 279 \\
\hline Query & 246 & $\begin{array}{l}\text { AGTATTC } \\
|||||| \mid\end{array}$ & $\begin{array}{l}\text { TGGCGGGCATGCC } \\
||||||||||||||\end{array}$ & 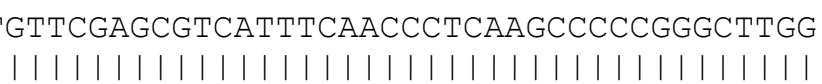 & 305 \\
\hline Sbjet & 280 & AGTATTC & TGGCGGGCATGCC & 'GTTCGAGCGTCATTTCAACCCTCAAGCCCCCGGGCTTGG & 339 \\
\hline Query & 306 & $\begin{array}{l}\text { TGTTGGG } \\
|||||| \mid\end{array}$ & GATCGGCCTGCCC & $\begin{array}{l}\text { CCGCGGCGGGCCGTCCCCCAAATCTAGTGGCGGTCTCGC } \\
\text { (a) }\end{array}$ & 365 \\
\hline Sbjet & 340 & TGTTGGG & GATCGGCCTGCCC & CCGCGGCGGGCCGTCCCCCAAATCTAGTGGCGGTCTCGC & 399 \\
\hline Query & 366 & $\begin{array}{l}\text { TGCAGCT } \\
|||||| \mid\end{array}$ & $\begin{array}{l}\text { TCCTCCGCGTAGT } \\
|||||||||||| \mid\end{array}$ & $\begin{array}{l}\text { GCAACACTCGCGCTGGAGCGCAGCGCGGCCACGCCGTTA } \\
|||||||||||||||||||||||||||||||||||||||||||| \mid\end{array}$ & 425 \\
\hline Sbjet & 400 & TGCAGCT & TCCTCCGCGTAGT & GCAACACTCGCGCTGGAGCGCAGCGCGGCCACGCCGTTA & 459 \\
\hline Query & 426 & 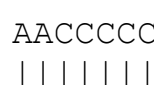 & CACTTCTGAAAGG & TGACCTCGGATCAGGTAGGAATACCCGCTGAACTTAAGC & 485 \\
\hline Sbjet & 460 & AACCCCC & CACTTCTGAAAGG & TGACCTCGGATCAGGTAGGAATACCCGCTGAACTTAAGC & 519 \\
\hline Query & 486 & $\begin{array}{l}\text { ATATCAA } \\
|||||| \mid\end{array}$ & 492 & & \\
\hline Sbjet & 520 & ATATCAA & 526 & & \\
\hline
\end{tabular}


Table 3: NCBI nucleotide blast results for sequences from a Fusarium fungus isolated from bark of Fagus grandifolia (query) and Fusarium tricinctum isolate HLJ_11, Sequence ID: gbJN088234.1 (subject).

\begin{tabular}{|c|c|c|c|c|c|}
\hline \multirow{2}{*}{\multicolumn{2}{|c|}{$\begin{array}{c}\text { Score } \\
928 \operatorname{bits}(502)\end{array}$}} & \multirow{2}{*}{$\begin{array}{l}\text { Expect } \\
0.0\end{array}$} & \multirow{2}{*}{$\begin{array}{l}\text { Identities } \\
502 / 502(100 \%)\end{array}$} & \multirow{2}{*}{$\begin{array}{l}\text { Gaps } \\
0 / 502(0 \%)\end{array}$} & \multirow[b]{3}{*}{74} \\
\hline & & & & & \\
\hline Query & 15 & \multicolumn{3}{|c|}{$\begin{array}{l}\text { CTCCAACCCCTGTGACATACCTTAATGTTGCCTCGGCGGATCAGCCCGCGCCCGgtAAAA } \\
|||||||||||||||||||||||||||||||||||||||||||||||||||||||||||||||||| \mid\end{array}$} & \\
\hline Sbjct & 16 & \multicolumn{3}{|c|}{ СTCCAACCCCTGTGACATACCTTAATGTTGCCTCGGCGGATCAGCCCGCGCCCGGTAAAA } & 75 \\
\hline Query & 75 & \multicolumn{3}{|c|}{$\begin{array}{l}\text { CGGGACGGCCCGCCAGAGGATCCAAACTCTTGCTGTTATTGTAACTTCTGAGTAAAACAA } \\
|||||||||||||||||||||||||||||||||||||||||||||||||||||||||||||||| \mid\end{array}$} & 134 \\
\hline Sbjct & 76 & \multicolumn{3}{|c|}{ CGGGACGGCCCGCCAGAGGATCCAAACTCTTGCTGTTATTGTAACTTCTGAGTAAAACAA } & 135 \\
\hline Query & 135 & \multicolumn{3}{|c|}{$\begin{array}{l}\text { ACAAATAAATCAAAACTTTCAACAACGGATCTCTTGGTTCTGGCATCGATGAAGAACGCA } \\
|||||||||||||||||||||||||||||||||||||||||||||||||||||||||||||||| \mid\end{array}$} & 194 \\
\hline Sbjct & 136 & \multicolumn{3}{|c|}{ АСАААTAАATCAАAАCTTTCAACAACGGATCTCTTGGTTCTGGCATCGATGAAGAACGCA } & 195 \\
\hline Query & 195 & \multirow{2}{*}{\multicolumn{3}{|c|}{$\begin{array}{l}\text { GCAAAATGCGATAAGTAATGTGAATTGCAGAATTCAGTGAATCATCGAATCTTTGAACGC } \\
|||||||||||||||||||||||||||||||||||||||||||||||||||||||||||||||||||| \mid) \\
\text { GCAAAATGCGATAAGTAATGTGAATTGCAGAATTCAGTGAATCATCGAATCTTTGAACGC }\end{array}$}} & 254 \\
\hline Sbjct & 196 & & & & 255 \\
\hline Query & 255 & \multirow{2}{*}{\multicolumn{3}{|c|}{$\begin{array}{l}\text { ACATTGCGCCCGCCAGTATTCTGGCGGGCATGCCTGTTCGAGCGTCATTTCAACCCTCAA } \\
||||||||||||||||||||||||||||||||||||||||||||||||||||||||||||||||||) \\
\text { ACATTGCGCCCGCCAGTATTCTGGCGGGCATGCCTGTTCGAGCGTCATTTCAACCCTCAA }\end{array}$}} & 314 \\
\hline Sbjet & 256 & & & & 315 \\
\hline Query & 315 & \multicolumn{3}{|c|}{$\begin{array}{l}\text { GCCCCCGGGTTTGGTGTTGGGGATCGGCAAGCCTTCTGGCGAGCCGCCCCCTAAATCTAG } \\
||||||||||||||||||||||||||||||||||||||||||||||||||||||||||||||||||\end{array}$} & 374 \\
\hline Sbjct & 316 & \multicolumn{3}{|c|}{ GCCCCCGGGTTTGGTGTTGGGGATCGGCAAGCCTTCTGGCGAGCCGCCCCCTAAATCTAG } & 375 \\
\hline Query & 375 & \multicolumn{3}{|c|}{$\begin{array}{l}\text { TGGCGGTCTCACTGCAGCCTCCATTGCGTAGTAGCTAACACCTCGCAACTGGAACGCGGT } \\
||||||||||||||||||||||||||||||||||||||||||||||||||||||||||||||||||||\end{array}$} & 434 \\
\hline Sbjet & 376 & \multicolumn{3}{|c|}{ TGGCGGTCTCACTGCAGCCTCCATTGCGTAGTAGCTAACACCTCGCAACTGGAACGCGGT } & 435 \\
\hline Query & 435 & \multicolumn{3}{|c|}{$\begin{array}{l}\text { GCGGCCATGCCGTTAAACCCCCAACTTCTGAATGTTGACCTCGGATCAGGTAGGAATACC } \\
||||||||||||||||||||||||||||||||||||||||||||||||||||||||||||||||||||\end{array}$} & 494 \\
\hline Sbjet & 436 & \multicolumn{3}{|c|}{ GCGGCCATGCCGTTAAACCCCCAACTTCTGAATGTTGACCTCGGATCAGGTAGGAATACC } & 95 \\
\hline Query & 495 & \multicolumn{2}{|c|}{$\begin{array}{l}\text { CGCTGAACTTAAGCATATCATA } \\
||||||||||||||||||||||)\end{array}$} & 516 & \\
\hline$t$ & 496 & \multicolumn{3}{|c|}{ CGCTGAACTTAAGCATATCATA } & \\
\hline
\end{tabular}

